
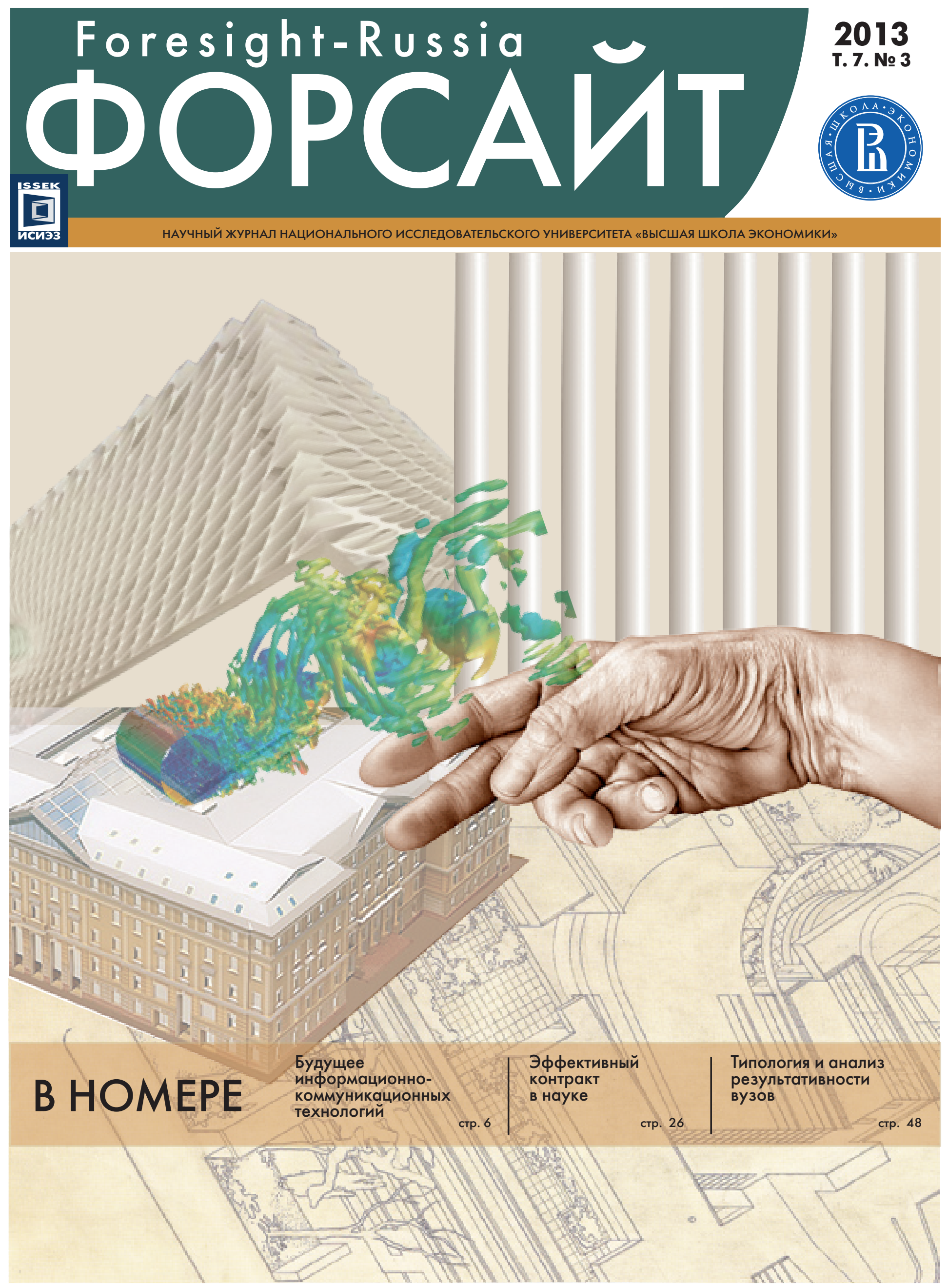


\section{SCOPUS"}

\section{EBSCO}

RePEe

SSR

(D) ULRichs NeE

\section{ELIBRARY,RU}

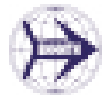

В соответствии с решением Высшей аттестационной комиссии Министерства образования и науки Российской Федерации журнал «Форсайт» включен в перечень ведущих рецензируемых научных журналов и изданий, выпускаемых

в Российской Федерации, рекомендованных для публикации основных научных результатов диссертаций на соискание ученой степени доктора и кандидата наук по направлению «Экономика» (протокол заседания президиума ВАК № 6/6 от 19 февраля 2010 г.).
Решением Экспертного совета по отбору изданий (Content Selection \& Advisory Board, CSAB) международного издательства Elsevier (июль 2013 г.) журнал «Форсайт» признан «ведущим российским изданием в своей предметной области" и включен в крупнейшую реферативную и аналитическую базу данных

\section{SCEPUS}

В настоящий момент в Scopus представлены 323 отечественных научных журнала (лишь 76 издаются на русском языке). Из них 23 относятся к области социальных наук, в том числе три по экономике, включая «Форсайт».

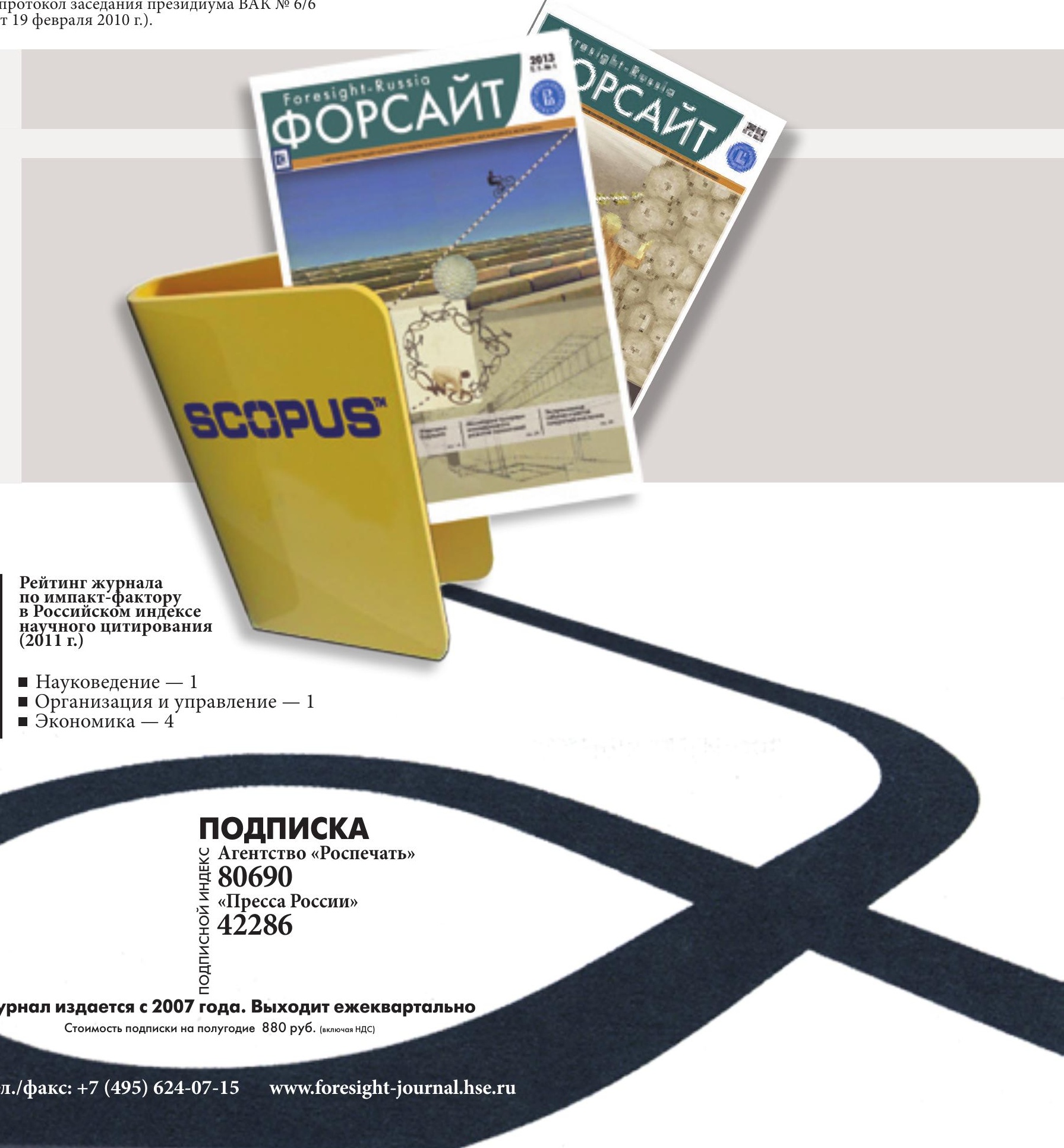




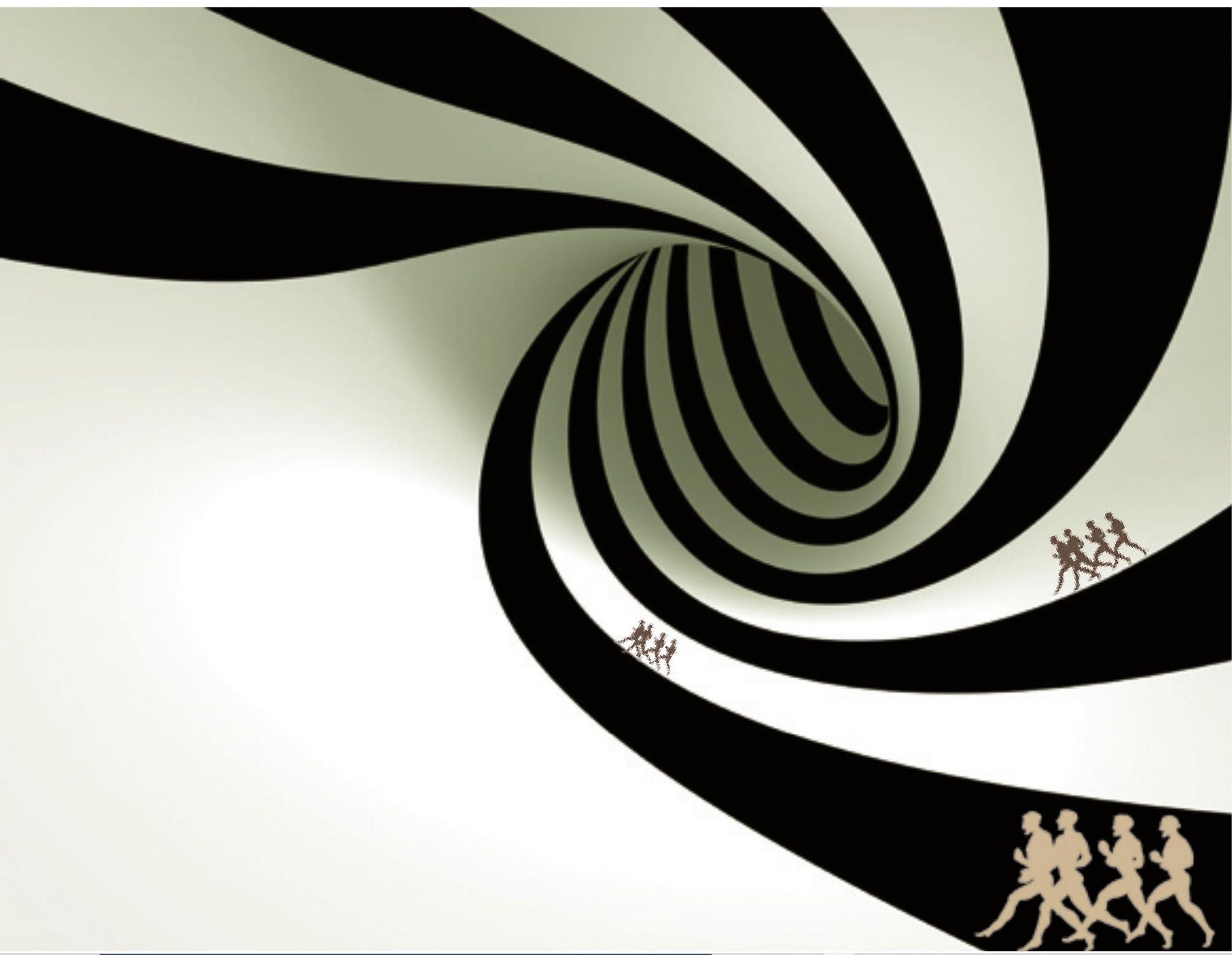

подписавшимся на четыре выпуска журнала ФОРСАЙТ СТАТИСТИЧЕСКИЕ СБОРНИКИ

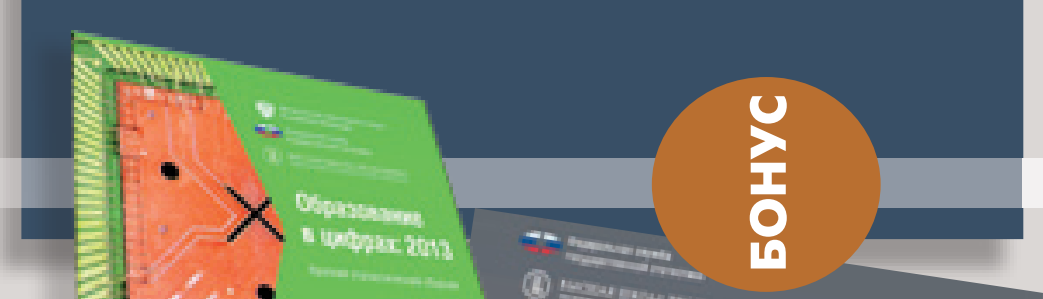

$\bullet$
0 cosing

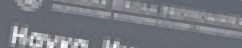

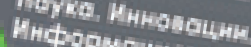

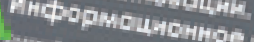

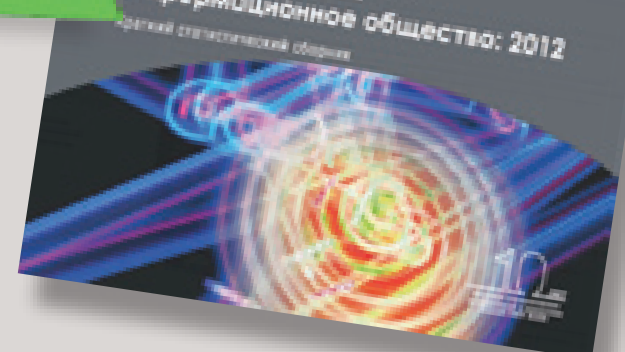

Эти и другие издания можно приобрести через Интернет и в книжных магазинах Подробная информация:

+7 (495) 621-28-73

Web: http://issek.hse.ru/buy

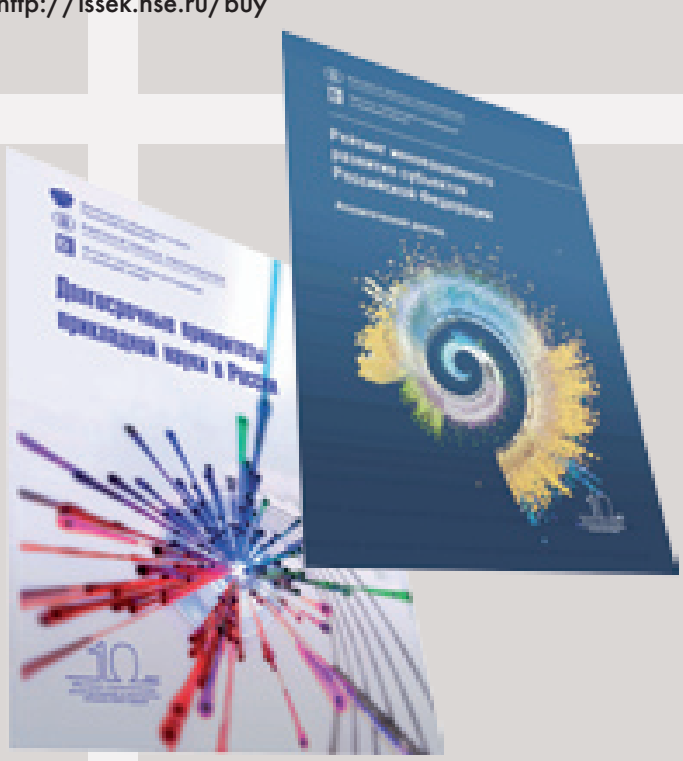




\section{ФОРСАЙТ}

ISSN 1995-459X

Периодичность выхода - 4 раза в год

Главный редактор Л.М. Гохберг (НИУ ВШЭ)

Заместитель главного редактора А.В. Соколов (НИУ ВШЭ)

\section{РЕДАКЦИОННАЯ КОЛЛЕГИЯ}

Т.Е. Кузнецова (НИУ ВШЭ)

Д. Майсснер (НИУ ВШЭ)

М.В. Рычев (НИЦ «Курчатовский институт»)

Ю.В. Симачев (Межведомственный аналитический центр)

Т. Тернер (НИУ ВШЭ и Университет Кейптауна, ЮАР)

\section{РЕДАКЦИОННЫЙ СОВЕТ}

И.Р. Агамирзян (Российская венчурная компания)

А.Р. Белоусов (Администрация Президента РФ)

Ж. Гине (НИУ ВШЭ)

М. Кинэн (ОЭСР)

А.Н. Клепач (Минэкономразвития России)

М.В. Ковальчук (НИЦ «Курчатовский институт»)

Я.И. Кузьминов (НИУ ВШЭ)

К. Леонард (НИУ ВШЭ и Оксфордский университет, Великобритания)

Дж. Линтон (Университет Оттавы, Канада)

Й. Майлс (НИУ ВШЭ и Университет Манчестера,

Великобритания)

С.Г. Поляков (Фонд содействия развитию малых форм предприятий в научно-технической сфере)

О. Саритас (НИУ ВШЭ и Университет Манчестера,

Великобритания)

М. Сервантес (ОЭСР)

Л. Сюэ (Университет Цинхуа, Китай)

А.В. Хлунов (Администрация Президента РФ)

Ч. Эдквист (Университет Лунда, Швеция)

\section{РЕДАКЦИЯ}

\section{Ответственный редактор}

М.В. Бойкова

Литературный редактор

Н.А. Гавриличева

Корректор

Н.В. Яровикова

Художник

М.Б. Зальцман

Верстка

М.Г. Салазкин

\section{Адрес редакции:}

101000, Москва, Мясницкая ул., 20

Национальный исследовательский университет

«Высшая школа экономики»

Телефон: +7 (495) 624-07-15

E-mail: foresight-journal@hse.ru

Web: http://foresight-journal.hse.ru

Издание зарегистрировано Федеральной службой по надзору в сфере связи, информационных технологий и массовых коммуникаций, регистрационный номер ПИ № ФС 77-52643 от 25.01.2013

\section{Учредитель:}

Национальный исследовательский университет

«Высшая школа экономики»

Тираж 1000 экз. Заказ

Отпечатано в ОАО «Можайский полиграфический комбинат», 143200, г. Можайск, ул. Мира, 93

www.oaompk.ru, www.оаомпк.pф

тел. (495) 745-84-28, (49638) 20-685

() Национальный исследовательский университет «Высшая школа экономики»

\section{ИНДЕКС}

\section{организаций, упомянутых в номере}

Business Object

Facebook

\begin{tabular}{lr} 
Frost\&Sullivan & 7 \\
GigaOm Pro & 8 \\
\hline
\end{tabular}

\begin{tabular}{lr} 
Google & 10,14 \\
\hline IBM & 13
\end{tabular}

Intel

KXEN

Oracle

RAND Corp.

SAS

Springer

Springer
SPSS

Technopolis Ltd.

TIBCO

Tufts Center

WikiVote!

Z-Punkt

Агентство по образованию (Department of Education), Филиппины

Академия Натальи Нестеровои

Белгородский госунарственный университет

BTO

Дагестанский государственный педагогический университет

\begin{tabular}{l|r} 
Дагестанский государственный педагогический университет & 55 \\
\hline Еврокомиссия & 50,80
\end{tabular}

\begin{tabular}{lr} 
Еврокомиссия & 50,80 \\
\hline Евростат & 8,25
\end{tabular}

\begin{tabular}{lr} 
Евростат & 8,25 \\
\hline Институт институциональных исследований (ИНИИ) НИУ ВШЭ & $39-46$
\end{tabular}

Институт исследований будущего (Institute for the Future), США

Институт перспективных технологических исследований (Institute for

Prospective Technological Studies, IPTS), Испания

Институт развития образования (ИРО) НИУ ВШЭ

Институт статистических исследований и экономики знаний (ИСИЭЗ)

НИУ ВШЭ

Институт экономических исследований фирм и роста (Institute for

Economic Research on Firms and Growth, CERIS) Национального

исследовательского совета Италии

Калужский государственный педагогический университет

Корейский институт оценки и планирования в области науки

, KISTEP)

Лицей № 1533 (информационных технологий) г. Москвы

МГУ им. М.В. Ломоносова

\begin{tabular}{l|l} 
Минобрнауки России & $26,30,48,55,60$
\end{tabular}

Минфин России

МИСиС

МИФИ

Московская высшая школа социальных и экономических наук $\quad 55$

Московская государственная юридическая академия $\quad 55$

\begin{tabular}{|r|r} 
Московская финансово-юридическая академия & 55 \\
\hline
\end{tabular}

\begin{tabular}{|l|r|}
\hline Московский государственный строительный университет & 55 \\
\hline Московский институт экономики и финансов НИУ ВШЭ & 32 \\
\hline
\end{tabular}

МФТИ

Национальный институт научно-технологической полити

Institute of Science and Technology Policy, NISTEP), Япония
Национальный исследовательский университет «Высшая школа
экономики» (НИУ ВШЭ)

$6,26,28,37,38$,
$48,55,74-77,81$

\begin{tabular}{l|r}
$48,55,74-77,81$ \\
\hline
\end{tabular}

Национальный исследовательский совет (National Research Council, CNR),

$74,79,80$

Национальный центр научных исследований (Centre national de la

Несемецкое научное сообщество (Deutsche Forschungsgemeinschaft, DFG),
Нермания

\begin{tabular}{|l|r|}
\hline НИЦ «Курчатовский институт» & 83 \\
\hline Об
\end{tabular}

Общество Макса Планка (Max Planck Gesellschaft), Германия 76

Oбъединенный исследовательский центр Еврокомиссии (Joint Research
Centre)

Centre)

Организация прикладных научных исследований (Dutch Organization for

Applied Scientific Research, TNO), Нидерланды

$\mathrm{OЭCP}$

Правительство Великобритании

Правительство Венесуэлы

Правительство РФ

$\mathrm{PAH}$

Российский гуманитарный научный фонд (РГНФ)

Российский университет дружбы народов (РУДН)

Российский фонд фундаментальных исследований (РФФИ)

Росстат

Санкт-Петербургский горный институт

Сибирский федеральный университет

Сиби й

У

Университет Sunshine Coast (University of the Sunshine Coast), Австралия $\quad 64$

$\begin{array}{lr}\text { Университет Брайтона (University of Brighton), Великобритания } & 74 \\ \text { Университет Кембриджа (University of Cambridge), Великобритания } & 50\end{array}$

Университет Лондона (University of London), Великобритания

Университет Манчестера (University of Manchester), Великобритания $\quad 31,50,52,74$

\begin{tabular}{|l|r|} 
Университет Оксфорда (University of Oxford), Великобритания & 50 \\
\hline Университет Твенте (University of Twente), Нидерланды & $50,51,74,76$
\end{tabular}

уральский государственный технический университет

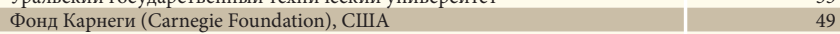

Фраунгоферовское общество (Fraunhofer Gesellschaft), Германия

Центр исследований менеджмента инновац

in Innovation Man
Великобритания

Центр Карнеги (Carnegie Center)

Центр технических исследований (VTT Technical Research Centre),

Финляндия

Челябинский государственний перагогчесий универс

уий университет 55

ЮНЕСКО

ЮНИДО (1) 


\section{СОДЕРЖАНИЕ}

T. 7, № 2 (2013)

ENGLISH

About the journal

Contents

\section{СТРАТЕГИИ}

Будущее России:

макроэкономические сценарии

в глобальном контексте

Е.А. Абрамова, А.Ю. Апокин, Д.Р. Белоусов, К.В. Михайленко, Е.А. Пенухина, А.С. Фролов

Индикаторы

\section{ИННОВАЦИИ И ЭКОНОМИКА}

Концентрация интеллектуальной деятельности в Италии: анализ на локальном уровне

Л. Мореттини, Д. Перани, Дж. Сирилли

\section{Индикаторы}

Исследовательские университеты в структуре региональной инновационной системы: опыт Остина, штат Техас

Д. Батлер, Д. Гибсон

\section{ТЕНДЕНЦИИ}

Взаимодействие человека и компьютера: тенденции, исследования, будущее K. Axметов

Индикаторы

\section{сОБЫтиЕ}

XIV Международная научная конференция НИУ ВШЮ

по проблемам развития экономики и общества. Секция «Государственное инвестирование в исследования и разработки: формирование, создание и управление центрами превосходства»

4

6
T. 7, № 3 (2013)

\section{ENGLISH}

About the journal

5 Contents

\section{СТРАТЕГИИ}

Долгосрочные тренды развития сектора информационных и коммуникационных технологий

А.В. Гиглавый, А.В. Соколов, Г.И. Абдрахманова, А.А. Чулок, В.В. Буров

Индикаторы

\section{HAYKA}

Эффективный контракт в науке: параметры модели

М.А. Гершман, Т.Е. Кузнеизова

Академическая профессия

в сравнительной перспективе: 1992-2012

Е.В. Сиъак, М.М. Юдкевич

Типология и анализ научнообразовательной результативности российских вузов

И.В. Абанкина, Ф.Т. Алескеров, В.Ю. Белоусова, Л.М. Гохберг, К.В. Зиньковский, С.Г. Кисельгоф, C.В. Шъыдун

\section{МАСТЕР-КЛАСС}

Концептуальные основы

и эффекты Форсайт-исследований: классификация и практическое применение

M. Бассей

\section{СОБЫтИЕ}

Международный семинар «Государственные научные организации.

Взаимодействие науки и реального сектора экономики»
6 


\section{Foresight Russia}

\author{
ISSN 1995-459X
}

Foresight-Russia - a research journal that was established by the National Research University - Higher School of Economics (HSE) and is administered by the HSE Institute for Statistical Studies and Economics of Knowledge (ISSEK), located in Moscow, Russia. The mission of the journal is to support the creation of Foresight culture in Russia through the dissemination of the best Russian and international practices in the field of futureoriented innovation development. It also provides a framework for a discussion of S\&T trends and policies. The following key issues are addressed:

- Foresight methodologies

- Results of Foresight studies implemented in Russia and abroad

- Long-term priorities of social, economic and S\&T development

- S\&T and innovation trends and indicators

- S\&T and innovation policies

- Strategic programmes of innovation development at national, regional, sectoral and corporate levels

- State-of-the-art methodologies and best practices of S\&T analyses and Foresight.

The target audience of the journal comprises research scholars, university professors, policymakers, businessmen, expert community, post-graduates, undergraduates and others who are interested in S\&T and innovation analyses, Foresight and policy issues.

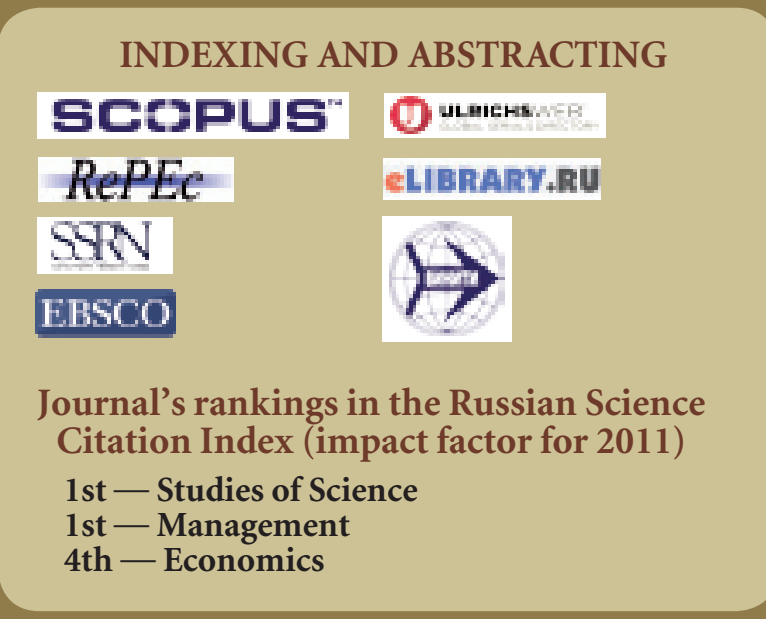

The thematic focus of the journal makes it a unique Russian language edition in this field. Foresight-Russia is published quarterly and distributed in Russia and abroad.
National Research University Higher School of Economics

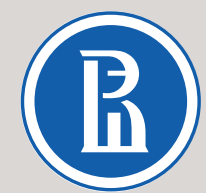

Institute for Statistical Studies and Economics of Knowledge

\section{EDITORIAL COUNCIL}

Leonid Gokhberg, Editor-in-Chief, First Vice-Rector, HSE, and Director, ISSEK, HSE, Russian Federation

Alexander Sokolov, Deputy Editor-in-Chief, HSE, Russian Federation

Igor Agamirzyan, Russian Venture Company, Russian Federation

Andrey Belousov, Administration of the President of the Russian Federation, Russian Federation

Mario Cervantes, Directorate for Science, Technology and Industry, OECD, France

Charles Edquist, Lund University, Sweden

Jean Guinet, HSE, Russian Federation

Michael Keenan, Directorate for Science, Technology and Industry, OECD, France

Alexander Khlunov, Administration of the President of the Russian Federation, Russian Federation

Andrey Klepach, Ministry of Economic Development of the Russian Federation, Russian Federation

Mikhail Kovalchuk, National Research Centre

«Kurchatov Institute», Russian Federation

Yaroslav Kuzminov, HSE, Russian Federation

Carol S. Leonard, HSE and University of Oxford, United

Kingdom

Jonathan Linton, University of Ottawa, Canada

Ian Miles, HSE and Manchester University, United

Kingdom

Sergey Polyakov, Foundation for Assistance to Small Innovative Enterprises, Russian Federation

Ozcan Saritas, HSE and Manchester University, United Kingdom

Lan Xue, Tsinghua University, China

\section{EDITORIAL BOARD}

Tatiana Kuznetsova, HSE, Russian Federation

Dirk Meissner, HSE, Russian Federation

Mikhail Rychev, National Research Centre

«Kurchatov Institute», Russian Federation

Yury Simachev, Interdepartmental Analytical

Centre, Russian Federation

Thomas Thurner, HSE and University of Cape Town

(South Africa)

\section{EDITORIAL STAFF}

Executive Editor - Marina Boykova

Literary Editor - Nataliya Gavrilicheva

Proof Reader - Nataliya Yarovikova

Designer - Mariya Salzmann

Pre-Press - Mikhail Salazkin

Our address:

National Research University - Higher School of Economics

20, Myasnitskaya str., Moscow, 101000, Russia

Tel: +7 (495) 624-07-15

E-mail: foresight-journal@hse.ru

Web: http://foresight-journal.hse.ru 


\section{Periodicity - Quarterly}

\section{CONTENTS}

Vol. 7, No 2 (2013)

\section{CONTENTS}

Vol. 7, No 3 (2013)
ENGLISH

About the journal

Contents

\section{STRATEGIES}

Future of Russia: Macroeconomic

Scenarios in the Global Context

Elena Abramova, Alexander Apokin,

Dmitry Belousov, Kirill Mikhailenko,

Elena Penukhina, Alexander Frolov

Indicators

\section{INNOVATION AND ECONOMY}

The Concentration of Knowledge

Activities in Italy: An Analysis

at Local Level

Lucio Morettini, Giulio Perani, Giorgio Sirilli

Indicators

Research Universities in the

Framework of Regional Innovation Ecosystem: The Case of Austin, Texas

John Butler, David Gibson

\section{TRENDS}

Human-Computer Interaction: Trends, 58 Research, Future

Kamill Akhmetov

Indicators

EVENT

XIV HSE International Academic Conference on Economic and Social Development.

Section «Global Trends in Public R\&D Investments - Designing, Establishing and Operating Centres of Excellence»

ENGLISH

A Typology and Analysis of Russian Universities' Research and Educational Performance

Irina Abankina, Fuad Aleskerov,

Veronika Belousova, Leonid Gokhberg,

Kirill Zinkovsky, Sofya Kiselgof,

Sergey Shvydun

\section{MASTER CLASS}

Conceptual Frameworks of Foresight and Their Effects: A Typology and Applications

Marcus Bussey

\section{EVENT}

International Workshop «Public

Research Organisations and Industry-

Science Links» 


\section{Долгосрочные тренды развития сектора информационно-коммуникационных технологий ${ }^{1}$}

\section{А.В. Гиглавый', А.В. Соколов", Г.И. Абдрахманова"II, А.А. Чулок' , В.В. Буров}

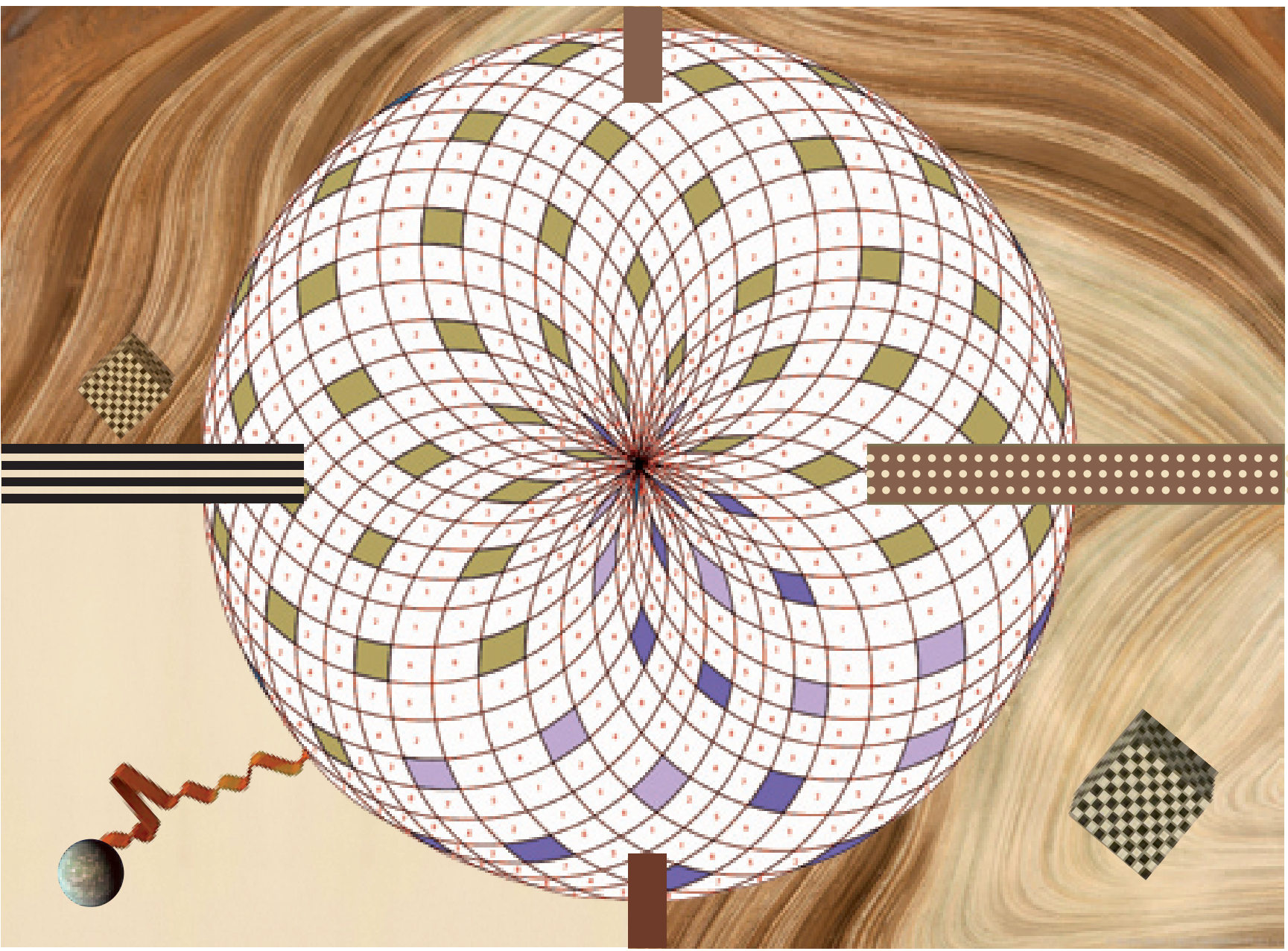

Трансформационные эффекты, оказываемые информационно-коммуникационными технологиями (ИКТ) на развитие различных сфер деятельности, привлекают пристальное внимание исследователей. Динамика этого сектора зависит от глобальных вызовов и трендов более широкого характера, определяющих долгосрочные приоритеты науки и технологий. Поэтому выявление внешних и внутренних факторов, которые повлияют на будущее ИКТ, - сверхактуальная задача. В статье представлен прогноз развития данного направления, оцениваются временные горизонты появления тех или иных технологических решений. Обозначены области, в которых Россия обладает определенными заделами и преимуществами.

\footnotetext{
Статья подготовлена по итогам исследования «Мониторинг глобальных технологических трендов», выполненного при поддержке Программы фундаментальных исследований НИУ ВШЭ. Отдельные результаты прогноза научно-технологического развития России в сфере ИКТ представлены научно-технологичесог Рако, Чулок, 2012; Качкаева, Кирия, 2012; НИУ ВШЭ, в публикациях [Соколов,
}

Гиглавый Александр Владимирович - заместитель директора по науке, Лицей № 1533 (информационных технологий) г. Москвы. E-mail: giglavy@yandex.ru Адрес: 119296, Москва, Ломоносовский проспект, 16

II Соколов Александр Васильевич - заместитель директора, директор Международного научно-образовательного Форсайт-центра. E-mail: sokolov@hse.ru

III Абдрахманова Гульнара Ибрагимовна - директор Центра статистики и мониторинга информационного общества. E-mail: gabdrakhmanova@hse.ru

IV Чулок Александр Александрович — заведующий отделом научно-технического прогнозирования. E-mail: achulok@hse.ru

Институт статистических исследований и экономики знаний (ИСИЭЗ) НИУ ВШЭ

Адрес: Национальный исследовательский университет «Высшая школа экономики», 101000, Москва, Мясницкая ул., 20

Буров Василий Владимирович - председатель совета директоров, WikiVote! E-mail: burov@wikivote.ru Адрес: 125047, Москва, ул. Фадеева, 7, стр.1, оф. 2

\section{Ключевые слова}

информационно-коммуникационные технологии; долгосрочный прогноз; глобальные вызовы; тренды; приоритетные направления; научно-технический задел 
И нформационно-коммуникационные технологии в течение последних десятилетий выступают одним из ключевых драйверов социально-экономического прогресса. Их развитие и широкое распространение способствуют трансформации облика многих секторов экономики; повышению качества жизни; эффективности ведения бизнеса и государственного управления; возникновению новых форм обучения, коммуникации и социализации людей; обеспечению доступа к различным видам информации. В свою очередь, динамика ИКТ сама существенным образом зависит от глобальных вызовов и трендов более широкого характера, определяющих долгосрочные приоритеты науки и технологий.

Какие факторы окажут воздействие на будущее сектора ИКТ? Какие технологические решения определят его облик в последующие 15-20 лет? Попытки ответить на эти и подобные вопросы были предприняты специалистами ИСИЭЗ НИУ ВШЭ при реализации комплекса исследований тенденций научно-технологического развития на глобальном и национальном уровнях.

\section{Методология}

Методология исследования основывалась на современных принципах Форсайта ${ }^{2}$ и предусматривала комбинацию количественных и качественных методов. В рамках проекта рассматривались цели развития сектора ИКТ и отражающие их индикаторы (с учетом ориентиров, установленных российскими и международными стратегическими документами); проводился скрининг долгосрочных трендов (по материалам более чем сотни мировых прогнозов и тематических обзоров ${ }^{3}$ ); анализировались глобальные социально-экономические и научно-технологические вызовы $^{4}$, затрагивающие сферу ИКТ; оценивались потенциальные окна возможностей для России, перспективные направления науки и технологий; инновационные рынки и появление на них новых продуктов и услуг. Это позволило сформулировать рекомендации по мерам научно-технической и инновационной политики. Базой для изучения инновационных рынков, продуктов и услуг послужили оценки динамики существующих, традиционных областей применения ИКТ под влиянием глобальных вызовов и национальных тенденций, а также предпосылок к появлению новых, прорывных («разрушающих») технологий и сопутствующих им эффектов. Тем самым обеспечивалось совмещение генетического (technology push) и нормативного (market pull) подходов к прогнозированию.

Приоритеты для различных сегментов определялись по таким критериям, как соответствие глобальным трендам, наличие конкурентных преимуществ и научно-технологических заделов, потенциал выхода на сложившиеся рынки и создания новых рыночных ниш, что, в свою очередь, позволило оценить перспективы научно-технологического развития отечественного сектора ИКТ.

Результаты прогноза прошли валидацию в рамках серии экспертных обсуждений высокого уровня с участием представителей ведущих компаний, научных центров, университетов и международных организаций. На их основе были разработаны предложения по «пакетам технологий» в качестве ответов на выявленные вызовы и проблемы; созданы дорожные карты, визуализирующие взаимосвязи наиболее важных аспектов долгосрочного развития сектора ИКТ, его ключевые направления, а также факторы, препятствующие повышению конкурентоспособности национальных производителей.

\section{Ключевые тренды}

Перспективный облик сферы ИКТ определит, прежде всего, переход к экономике, основанной на знаниях. Этот процесс начался с проникновения рассматриваемых технологий в материальное производство и сегодня набирает обороты по мере насыщения ими сферы услуг (финансы, страхование, торговля, транспортная инфраструктура и т. п.), однако его эффекты в полной силе проявятся только в будущем [OECD, 2013]. ИКТ вносят серьезный вклад и в решение глобальных проблем, таких как:

- исчерпание дешевых природных ресурсов;

- старение населения;

- ухудшение состояния окружающей среды;

- потеря эффективного контроля над технологическими цепочками;

- вытеснение национальных производителей с внутренних рынков;

- мобильность кадров;

- миграция финансовых капиталов;

- неустойчивость глобальной экономической и политической системы;

- растущий дисбаланс между требованиями безопасности и личной свободой человека;

- рост киберпреступности, увеличение масштаба ее эффектов и др. ${ }^{5}$

Развитие рынков ИКТ сочетает эволюционную траекторию (совершенствование существующих продуктов (услуг), экстенсивный рост сложившихся сегментов за счет резкого снижения цены последних) с экспоненциальной моделью проникновения инноваций, способствующей распространению новейших разновидностей ИКТ и возникновению на этой базе новых рынков [Forge et al., 2009; Калин, 2010; European Commission, 2009]. Все это повышает инвестиционную привлекательность отрасли, но присутствие на мировом рынке ИКТ большого числа «разрушающих» инноваций [Christensen, 1997] обусловливает волатильность финансовых результатов компаний данного и смежных секторов. Так, в 2012 г. более $40 \%$ ИКТ-фирм, входящих в рейтинг FT-500, ухудшили свои позиции [Financial Times, 2012].

\footnotetext{
Подробнее см., например: [Georghiou et al., 2008; Cagnin et al., 2013; Gokhberg, Sokolov, 2013; Haegeman et al., 2013; UNIDO, 2005].

3 В их числе: материалы ведущих зарубежных аналитических компаний (RAND Corp., Frost\&Sullivan, Z-Punkt и др.), международных проектов (SESTI, iKnowFuture, European Foresight Platform и др.), исследовательских центров (NISTEP, IPTS, KISTEP, Institute for the Future и др.).

4 Подход, получивший название «Большие вызовы» (Grand Challenges), детально описан в работе [European Commission, 2010b].

Подробнее о глобальных вызовах см.: [European Commission, 2010a].
} 
Серьезными драйверами инноваций становятся малый и средний бизнес. Бурное развитие компанийновичков, производящих прорывные продукты, будет активнее стимулироваться «сетецентричностью» и растущим спросом на встраиваемые цифровые устройства различного назначения.

Согласно международным прогнозам ожидается дальнейшее повышение вклада сектора ИКТ в экономический рост: к 2020 г. его доля в мировом ВВП достигнет 8.7\% [BCG, 2012, p. 18]. В России, по расчетам авторов статьи, на данный сектор приходится около $2.7 \%$ занятых в экономике и $3.1 \%$ ВВП страны, что соответствует среднеевропейским показателям. Для сравнения: в Финляндии их значения составляют 4.1 и 5.3\% соответственно, Германии - 2.3 и $4.3 \%$, Швеции -4.4 и $6.3 \%$, Испании - 2.0 и $3.5 \%{ }^{6}$.

Наиболее динамичный и масштабный сегмент образуют телекоммуникации и деятельность, связанная с использованием компьютерных устройств и информационных технологий (разработка программного обеспечения, консультирование, обработка информации, создание и использование баз данных и информационных ресурсов, в том числе Интернета, обслуживание вычислительной техники и т. п.). На них приходится соответственно 1.7 и 0.6\% ВВП, причем темпы прироста валовой добавленной стоимости здесь (соответственно 61 и 97\% в постоянных ценах за период 2012-2015 гг.) заметно опережают среднюю динамику и отрасли (52\%), и ВВП в целом (28\%).

Сектор ИКТ тесно связан с производством контента и массовыми коммуникациями, которые являются не только активными потребителями его продукции, но и драйверами совершенствования технических средств и технологий. По данным аналитического центра GigaOm Pro, мировой рынок цифрового контента к 2014 г. вырастет до 36 млрд долл. против 16.7 млрд долл. в 2009 г. [Zagaeski, 2010]. По состоянию на начало 2012 г., в России производство и распространение контента осуществляли свыше 50 тыс. организаций (с общей численностью занятых 251 тыс. чел.). Созданная ими валовая добавленная стоимость составила 233 млрд руб., или 0.4\% ВВП (прирост в постоянных ценах по сравнению с 2005 г. на 4\%).

Необходимость реагирования на подобного рода вызовы внешнего и внутреннего характера предъявляет спрос на развитие науки и технологий. Предстоит радикальная трансформация рынков в связи со сменой элементной базы технических средств. Роль ИКТ может измениться в зависимости от способности новых технологических решений поддержать рост производительности вычислительной техники. Конвергенция ИКТ с другими технологиями, в том числе нано-, био- и когнитивными, будет способствовать сохранению действия «закона Мура» и росту «сетевых эффектов» («закон Меткалфа»)7. Продолжат развиваться инновационные технологии социального сетевого взаимодействия, в частности «Интернет вещей» (Internet of Things) и «Интернет всего» (Internet of Everything), что приведет к сокращению жизненных циклов стандартов и технологических платформ ИКТ-систем и сетей.

Одновременно в новых условиях возникает ряд угроз, связанных с задачами преодоления «цифрового неравенства», равноправного вхождения в глобальное информационное пространство, быстрого и масштабного освоения новых технологий в социальной сфере и государственном управлении, обеспечения национальной безопасности.

В рамках проведенных исследований были идентифицированы основные глобальные тренды, которые кардинально преобразят сектор (рис. 1$)^{8}$.

Ускоряющийся прогресс технологий стимулирует спрос на «умную» продукцию в большинстве отраслей материального производства, а рынок приборов, средств автоматизации и систем управления в долгосрочной перспективе станет «сетецентричным»и интегрированным в отрасль.

Развитие облачных технологий (high throughput computing, НTC), новых архитектур и принципов организации высокопроизводительных вычислений (high performance computing, НРC) трансформирует программное обеспечение (ПО) и инфраструктуры отраслевых ИКТ-решений, произведет инновационные изменения в бизнес-стратегиях предприятий, создав по сути новую техносферу экономики.

Благодаря ИКТ возникают инновационные формы социализации. Во многих сегментах мирового рынка труда отпадает необходимость в «привязке» сотрудников к конкретному рабочему месту. В совокупности с глобальным дефицитом квалифицированных кадров и стремлением к снижению затрат на поддержание инфраструктуры предприятий подобный тренд приведет к распространению схем удаленной работы и становлению новых моделей занятости.

При всей универсальности, ИКТ окажут максимальный эффект в сфере услуг, а появляющаяся возможность накопления и хранения услуг высокого качества с их последующей передачей в любое время и в любую точку планеты существенно изменит облик этого направления.

\section{Технологии жизнеобеспечения}

Рассматриваемая группа технологий ориентирована на базовую систему ценностей человека как личности его физическое и психическое здоровье, продолжительность и качество жизни, расширение возможностей, заложенных природой 9 .

По мере роста ценности здоровья в системе приоритетов общества появляются новые медикотехнологические и социальные вызовы, обусловленные

\footnotetext{
Данные по России за 2012 г.; по зарубежным странам - за 2009 г. Источник: по России - расчеты ИСИЭЗ НИУ ВШЭ по данным Росстата, зарубежным странам - Евростат.

Гордон Мур, один из основателей компании Intel, в свое время сформулировал «закон», согласно которому количество транзисторов, размещаемых на кристалле интегральной схемы, удваивается каждые 24 месяца. «Закон Меткалфа» гласит, что экономическая ценность компьютерной сети растет примерно пропорционально квадрату числа ее пользователей [Hendler, Golbeck, 2008].

8 Мы не рассматриваем подробно тренды, касающиеся сферы массовых коммуникаций, поскольку они были представлены в ранее опубликованной статье [Качкаева, Кирия, 2012].

9 Проблема формирования новых условий жизни в информационном обществе стала актуальной темой исследований в развитых странах, например инициативы «Ambient Assisted Living» (AAL) (режим доступа: www.aal-europe.eu, дата обращения 25.06.2013).
} 

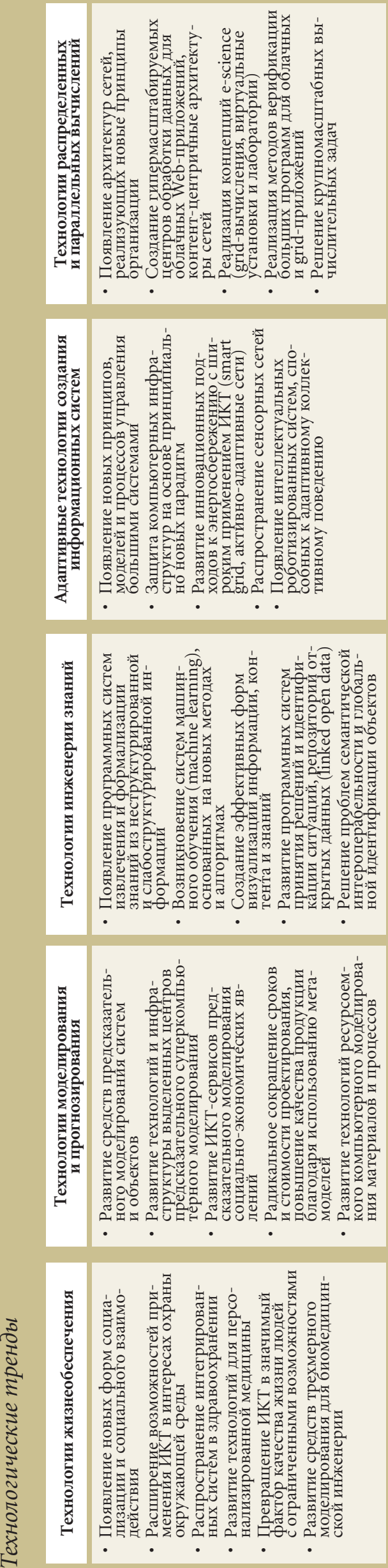
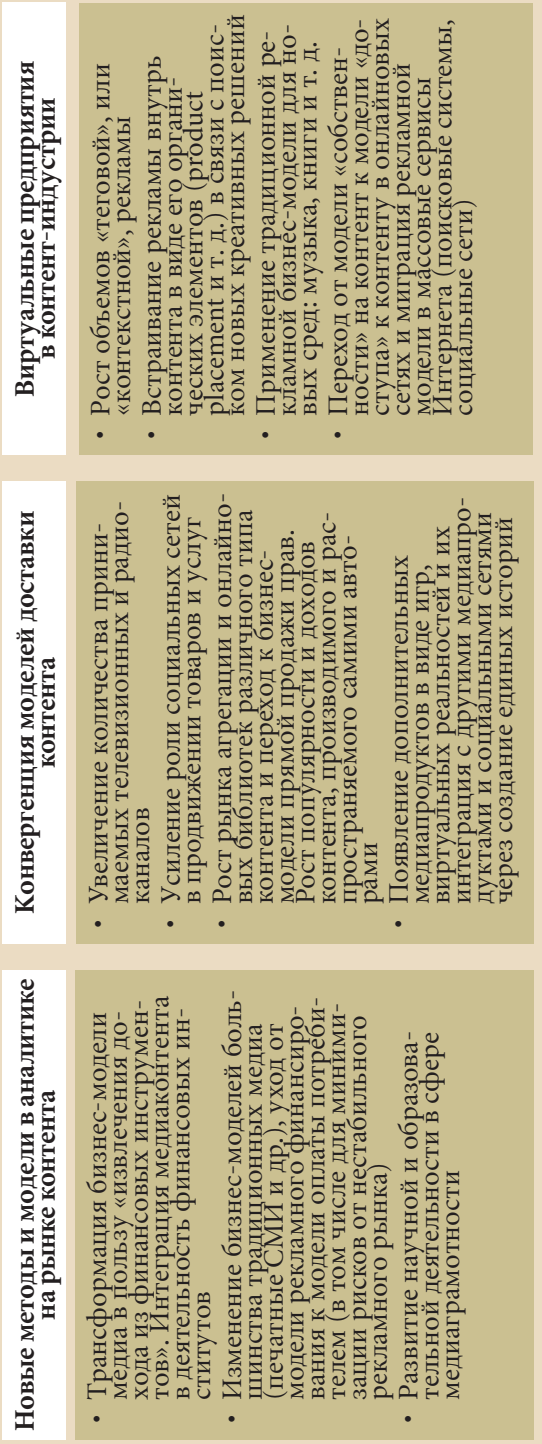

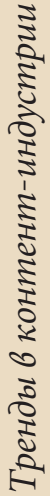

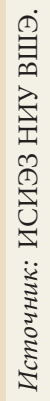


демографическими изменениями. Благодаря развитию медицинских технологий существенно расширяются возможности влияния на показатели здоровья населения. При этом прогресс в сфере ИКТ и их применение в повседневной жизни сдерживаются недостаточным уровнем решения проблем, связанных с обеспечением безопасности в сети, конфиденциальности и т. д.

Следует отметить и процессы формирования «цифрового облика» гражданина информационного общества: возникает совокупность информационных объектов, интегрирующая его систему ценностей и спектр интересов в общекультурной, профессиональной и социальной областях. Социальные сети, все теснее взаимодействующие с мобильными клиентскими устройствами, становятся фактором охраны здоровья и улучшения качества жизни (quality of life technologies) [Schulz, 2012]. Современные технологии повышают качество государственных услуг и поднимают на новый уровень зависимые от государства медицину и образование.

Появление новых форм социализации и социального взаимодействия. Влияние ИКТ на социальные процессы постоянно усиливается. Меняется культура; население вовлекается в управление общественной жизнью; улучшается среда обитания; создаются новые социальные блага. Одной из форм вовлечения, опирающейся на возможности социальных ИКТ-сервисов, становится причастность к принятию решений или отклонению деструктивных предложений. Повышение роли Интернета в целом, и «электронной демократии» в частности, постепенно стирает грань между гражданской активностью и политической деятельностью, что в перспективе может привести к возможности прямого влияния граждан на законодательные процедуры. Основное взаимодействие между государством и населением будет происходить в электронной форме, однако при этом возникает проблема однозначной идентификации и аутентификации пользователей для совершения действий, имеющих юридическую силу.

Действенным драйвером вовлечения граждан в управление становится краудсорсинг. Помимо государственного и муниципального управления, этот тип социальных технологий начинает распространяться и на корпоративный сектор. В ближайшие годы прогнозируются высокие темпы расширения социальной базы в различных сферах его применения.

Для значительной части населения планеты социальные ИКТ-сервисы стали неотъемлемым элементом общественной жизни. Об этом свидетельствует численность аудитории самых популярных провайдеров таких услуг - Google и Facebook: на каждом из них зарегистрировано уже свыше 1 млрд аккаунтов.

В развитых странах изменение структуры и расширение клиентской базы пользователей привело к возникновению новых бизнес-моделей, в первую очередь связанных с мобильными и развлекательными приложениями. В результате стали формироваться новые социальные категории, а также соответствующие модели поведения и взаимодействия. Подобные изменения выходят за рамки виртуальности и прони- кают в различные области общественной, культурной и политической жизни. Отметим, например, трансформацию подходов к воспитанию и образованию, направленную на интеграцию цифровой и классической составляющих культурного наследия.

Стремительный прогресс ИКТ меняет представление о роли и формате средств массовой информации. Расширение многообразия и «нишевизация» контента удовлетворяют разные вкусы потребителей, представляя угрозу для традиционных СМИ. В частности, речь идет о печатной продукции, которая, ориентируясь на массовый спрос, не может конкурировать с новыми способами доставки более персонифицированного и интерактивного контента.

Интернет как главный источник контента является центральным каналом получения сведений о культурных ценностях. Необходимость системного подхода к созданию цифровых копий шедевров культуры детерминирует долгосрочный характер такого тренда. Как следствие, среди приоритетных направлений расширение электронного доступа к культурным ценностям, находящимся в музеях и библиотеках, и другим произведениям искусства, что требуется увязать с проблемой авторских прав. Существует и феномен «изначально цифровых» объектов культурного наследия, для которых предстоит создать адекватные технологии сохранения и выработать новые социокультурные навыки использования.

Расширение возможностей в сфере охраны окружающей среды. Совершенствование территориально распределенных геоинформационных ресурсов и систем, обеспечивающих сбор, обработку, унифицированное хранение, а также коллективное использование картографических и других пространственных данных ${ }^{10}$, создает основу для устойчивого развития и формирования «зеленой экономики». Это приведет к распространению ИКТ-услуг, позволяющих контролировать природопользовательскую и иную хозяйственную деятельность компаний, а также государственных органов. По оценкам, объем мирового рынка таких услуг к 2020 г. может достичь сотен миллиардов долларов [McLaren, Kennedy, 2013].

Появление сенсорных сетей в локальных системах природоохранного назначения и решений в рамках концепции «Интернета вещей» радикально повышает комфортность среды обитания, прежде всего, за счет максимальной открытости экологической информации и интеграции социальных сетей с мобильными клиентскими устройствами. Уже сегодня наблюдается рост инновационного рынка подобных сервисов на основе инфраструктуры мобильной связи (М2M).

Внедрение «зеленых» технологий, охватывающих все этапы жизненного цикла производимых товаров и услуг, становится характерным и для самого сектора ИКТ. Так, руководствуясь требованиями международных и европейских экологических стандартов (ISO 14001:2004, OHSAS 18001:1999, ROHS, WEEE и др.), крупные телекоммуникационные компании приступили к реализации программ снижения вредного воздействия на окружающую среду, а экономия

\footnotetext{
${ }^{10}$ Включая данные о местности и объектах, расположенных на поверхности Земли, в ее подповерхностном слое, приповерхностном слое земной атмосферы и околоземном пространстве, необходимых для использования в различных сферах.
} 
электроэнергии, в свою очередь, позволяет существенно сокращать эксплуатационные расходы компаний.

Распространение интегрированных систем в здравоохранении. Здравоохранение становится одним из самых многообещающих рынков для ИКТ. В среднесрочной перспективе (до 2020 г.) ожидается массовое внедрение электронных паспортов здоровья, распределенных сетей телемедицинских центров, систем контроля качества и безопасности лекарственных средств и медицинских услуг.

К 2025 г. повсеместно будут использоваться медицинские микроустройства, встраиваемые в тело человека [Саритас, 2013; Каминский и др., 2013] и поддерживающие его жизненно важные функции; технологии обмена унифицированной информацией между транспортными средствами; методы позиционирования и идентификации объектов в концепции «Интернет вещей»; перспективные платформы сбора, обобщения и представления контента и знаний.

По мере увеличения ценности здоровья в системе национальных приоритетов возникают новые медикотехнологические и социальные вызовы, связанные с изменениями в демографической структуре населения. Благодаря развитию биомедицинских технологий значительно расширяются возможности влияния на показатели здоровья, о чем свидетельствуют успехи в борьбе с наиболее опасными для жизни заболеваниями, достигнутые в развитых странах за последние десятилетия.

В ближайшее время будут созданы специализированные порталы и системы круглосуточного мониторинга ключевых физиологических параметров человека на основе мобильных решений. Системы удаленного мониторинга пациентов посредством специализированной сенсорной сети индивидуальных медицинских приборов с подключением к компьютерам либо смартфонам через интерфейсы, стандартизованные по требованиям профилей IEEE и ISO, позволят сократить пребывание больных в стационаре, а после выписки врачи смогут отслеживать динамику их жизненных параметров, чтобы предупреждать критические состояния и оказывать консультативную помощь.

Высокий уровень соответствующей инфраструктуры свидетельствует о степени готовности лечебных учреждений России к новым формам применения ИКТ. По данным за 2011 г., 94\% из них использовали Интернет, 74\% - располагали широкополосным доступом, каждое второе $(47 \%)$ имело собственную вебстраницу или сайт [НИУ ВШЭ, 2013а].

Интенсивное развитие диагностики и лечения в сочетании с экстенсивным наращиванием инфраструктуры охраны здоровья составляет основу среднесрочных (2015-2020 гг.) национальных программ и в России, и в ведущих странах. В последних быстро растет число пожилых людей, располагающих финансовыми ресурсами для повышения качества жизни. Тиражирование разработанных для этих стран технологических и социальных решений становится возможным при снижении их стоимости в условиях быстрого роста масштабов рынка. Усиление защитных свойств организма с применением ИКТ, востребованное указанной возрастной группой, скорее всего, приведет к появлению широкого спектра «разрушающих» инноваций, способных радикально изменить облик здравоохранения.

Развитие технологий для персонализированной медицины. Благодаря достижениям в области цифровых технологий молекулярного дизайна, медицинской визуализации и методологии анализа новых типов данных в последнее десятилетие активно развивается персонализированная медицина. По данным исследовательской группы Tufts Center (США), за период 2010-2015 гг. инвестиции в эту сферу должны вырасти на 50\% [FDANEWS, 2010]. Использование геномной информации в долгосрочной перспективе позволит получить «личные» лекарства для многочисленных патологий. Их преимущества проявятся при лечении тяжелых социально значимых заболеваний.

Применение технологий дистанционного слежения за телодвижениями пациента поможет в лечении расстройств центральной нервной системы, обусловленных последствиями инсульта или иных заболеваний. Разработка беспроводных датчиков способствует созданию средств удаленного мониторинга, позволяющих заблаговременно обнаруживать болезни и исключить потребность в ежегодных скринингах. Появятся средства обработки мультимедийной информации в сетях хранения путем распараллеливания операций выявления семантических связей («новые истории болезни»).

По мере совершенствования методов и алгоритмов аналитической обработки «больших данных» будут созданы технологии формализации и извлечения знаний, что позволит применять прогностические мультивариантные биомаркеры для профилактики и лечения заболеваний. Массовые предварительные генетические обследования пациентов, основанные на использовании мощных вычислительных ресурсов и сложных алгоритмов, способны существенно сократить заболеваемость инсультом и онкологией.

Среди ИКТ-продуктов, применяемых в персонализированной медицине, - методы и алгоритмы анализа изображений, комплексные статистические методы и технологии компьютерного обучения персонала. В долгосрочной перспективе (до 2030 г.) на рынках фармацевтики и медицинского оборудования ожидается существенный рост доли затрат на ИКТ.

Превращение ИКТ в значимый фактор повышения качества жизни для людей с ограниченными возможностями. ИКТ позволяют сделать жизнь инвалидов полноценной, обеспечить им физическую, социальную, когнитивную и эмоциональную стабильность.

В настоящее время разрабатываются интерфейсы пользователей для систем лечебно-профилактического назначения с носимыми цифровыми устройствами по каналам «Интернета вещей» на базе новых когнитивных принципов. Проведены первые эксперименты по объединению нервных клеток и цифровых устройств в единую систему (создание нейрокремниевых интерфейсов) для подключения протезов органов и частей тела к нейронным сетям мозга и нервной системе. Реализация этого тренда будет определяться развитием инновационных моделей человеко-машинного 
интерфейса, основанных на достижениях когнитивных наук.

В среднесрочном периоде (2015-2020 гг.) получат широкое применение устройства компенсационного назначения (зрение, слух, тактильные ощущения и т. п.), интегрируемые с персональными коммуникационными и иными приборами (бытовая техника и электроника, транспортные средства и др.); в отдаленной перспективе - экзоскелеты для восстановительного лечения пациентов, изготавливаемые по технологии 3D-печати.

Значительно увеличится число рабочих мест с гибкими формами занятости (коворкинг, высококвалифицированный надомный труд), расширится сеть центров обработки вызовов для слабовидящих и слепых людей. Продолжится развитие дистанционных образовательных технологий и социальных сетей профессионального общения для индивидов с ограниченными возможностями. Выявление механизмов целенаправленного взаимодействия людей в сообществах посредством виртуального общения; разработка новых поколений интерфейсов «человек-машина», технологий распознавания речи, гибридных моделей когнитивных механизмов и речемыслительной деятельности человека; мобильные приложения, предлагающие различные интерфейсы между «Интернетом людей» и «Интернетом вещей», - все это позволит значительно интенсифицировать взаимодействие пользователей указанной категории с цифровой средой.

Развитие средств трехмерного моделирования для биомедицинской инженерии. В течение 15-20 лет, по мере реализации концепций интеллектуальной среды обитания и «Интернета вещей», существенно трансформируется инфраструктура здравоохранения. Развитие ИКТ-сервисов телемедицины обусловлено созданием в ближайшие годы комплекса процедур, обеспечивающих адекватный и надежный обмен медицинскими данными на расстоянии. Применение облачных и grid-технологий к 2020-2025 гг. позволит медицинским учреждениям совместно использовать высокотехнологичную аппаратуру.

Эффективность технологий виртуальных сцен и дополненной реальности вырастет за счет разработки прогрессивных алгоритмов и программ для обработки, хранения и передачи изображений различной природы (рентгеновские, УЗИ, эндоскопия, цитология

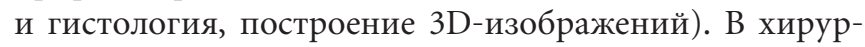
гической практике повышение точности определения позиции реальных микрообъектов приведет к появлению новых поколений инвазивных и неинвазивных методов диагностики и проведения операций.

Технологии построения сложных трехмерных сцен по изображениям и видеоряду в режиме реального времени (компьютерное зрение сверхвысокого разрешения) стимулируют совершенствование дистанционных методов диагностики. Особое значение эти инструменты приобретут в телерадиологических системах.

Медицинские исследования, связанные с ИКТ, все активнее выходят на наноуровень, в их числе - разработки в области генной инженерии (молекула ДНК имеет ширину 3 нанометра), биосовместимое протезирование (искусственные молекулы), целевая доставка лекарств в больные клетки с помощью наночастиц и многое другое. Биоинформатика нацелена на исследование геномов, анализ и предвидение структуры белков, изучение взаимодействий молекул белка между собой и с другими молекулами, а также на моделирование процессов эволюции [ЦМАКП, 2011]. Появился специальный термин «биология на кремнии» (in silico), т. е. проведение биологического эксперимента на компьютере.

\section{Технологии моделирования и прогнозирования}

Сегодня заложены теоретические основы построения метамоделей с высокой вычислительной эффективностью и требуемой точностью. Метамодели «обучаются» по множеству прототипов входных и выходных данных, а потому тесно связаны с инструментарием извлечения информации (data mining) — выявлением скрытых закономерностей или взаимосвязей между переменными в больших массивах необработанных данных.

Использование в построении метамоделей многодисциплинарной оптимизации позволит в дальнейшем существенно ускорить расчеты, снизив количество дорогостоящих натурных или вычислительных экспериментов.

Развитие средств предсказательного моделирования систем и объектов. Растущий спрос на информационные системы с применением технологий предсказательного моделирования для проектирования и управления социальными и производственными процессами обусловлен развитием сложных технологических систем и увеличением масштабов ущерба от техногенных катастроф. Предсказательное моделирование характеризуется, прежде всего, уровнем адекватности модели реальным условиям и временем реакции на запрос.

В 2015-2020 гг. преобладающее развитие получит технология метамоделирования на основе математических моделей, строящихся по результатам машинного обучения (machine learning) на многочисленных натурных и/или вычислительных экспериментах с различными объектами рассматриваемого класса. Фактически они имитируют как источники получения данных на базе соответствующей исходной модели, так и сами модели, созданные по результатам изучения физики процессов. Носящие название «суррогатных» (surrogate models), они, как правило, имеют повышенную вычислительную эффективность на фоне исходных [Gorissen et al., 2010]. Значительный эффект от реализации указанных технологий ожидается уже к концу текущего десятилетия.

Развитие технологий и инфраструктуры выделенных центров предсказательного суперкомпьютерного моделирования. Предсказательное моделирование природных, инженерных и социальных систем на суперкомпьютерных платформах не просто помогает исследователям формулировать гипотезы и сценарии, но и в значительной мере снижает риски принятия решений. Уже к 2020 г. преобладающей парадигмой работы суперкомпьютерных платформ станут облачные высокопроизводительные вычисления (НРС), однако их быстродействие и масштаб пока еще недостаточны. 
Создается модель вычислительного сервиса, получившая название «НРС в виде сервиса» (HPC as a service, $\mathrm{HPCaaS),} \mathrm{подразумевающая} \mathrm{простой} \mathrm{интерфейс} \mathrm{для}$ доступа к ресурсам высокопроизводительных систем.

Как полагают эксперты, в период 2020-2025 гг. стандартизованные интерфейсы доступа к совместно используемой инфраструктуре (в том числе на тонких и мобильных клиентских устройствах) повысят эффективность командной работы исследователей, инженеров и технологов независимо от их местонахождения. Модель сервиса HPCaAS повышает доступность процессов предсказательного моделирования, многократно ускоряя расчеты и снижая потребность в дорогостоящих натурных либо вычислительных экспериментах, что создает качественно новые возможности для распространения этих методов в научных исследованиях и инжиниринге.

Развитие ИКТ-сервисов предсказательного моделирования социально-экономических явлений. Предсказательная аналитика (predictive analysis, PA) представляет собой совокупность технологий, методов и алгоритмов для составления прогнозных моделей, позволяющих проецировать в будущее накопленные (в том числе исторические) данные, свойства, проявившие себя в прошлом и имеющие тенденцию к сохранению в будущем. Динамика ее рынка опирается на известные технологии сбора данных - кластеризацию, деревья решений, регрессионное моделирование, нейронные сети, глубинный анализ текстов (text mining) и проверку гипотез. В связи с необходимостью обработки огромных массивов неструктурированной информации создаются методы семантического анализа текстов и технологии работы с «большими данными», в результате активно распространяется предсказательное моделирование.

В среднесрочной перспективе (2015-2020 гг.) ${ }^{11}$ ожидается появление актуальных экономико-математических моделей для инновационного бизнеса. Ведущие компании (SAS, SPSS (IBM), KXEN, Oracle и TIBCO) оперируют перспективными математическими методами (например, статистическая теория обучения, применяемая к большим объемам исходных данных), позволяющими создавать устойчивые прогнозные модели с учетом множества переменных. На этой основе развиваются ИКТ-сервисы предсказательного моделирования социально-экономических явлений, способные повысить эффективность государственного и муниципального управления (в частности, сервисы для структурирования новостных потоков в социальных сетях и профессиональных веб-сообществах).

Радикальное сокращение сроков и стоимости проектирования, повышение качества продукции благодаря использованию метамоделей. Применение методов моделирования и прогнозирования напрямую повлияет на изменение требований к средствам технологической подготовки производства, контрольноизмерительным приборам и т. д. Их комбинирование с предсказательным моделированием при обработке причинно-следственных связей, характеризующих развитие сложных событий (complex event processing, CEP), усовершенствует проектирование систем массового обслуживания клиентов [Etzion, Nibblet, 2010].

В ближайшие годы повысится эффективность метамоделей в производстве при расчете надежности оборудования (оценка наработки на отказ), когда меняются логистика поставок комплектующих, условия работы поставщиков и иные внешние обстоятельства.

В более отдаленной перспективе (2020-2025 гг.) появятся программные комплексы для решения задач проектирования, конструирования, моделирования и инжиниринга сложных технологических объектов и систем, простые в эксплуатации и не требующие высокой квалификации пользователей.

Развитие технологий ресурсоемкого компьютерного моделирования материалов и процессов. Подобные разработки создадут основу для повышения конкурентоспособности ряда экономических секторов. Вычислительное материаловедение является одним из наиболее перспективных рынков наукоемких ИКТсервисов. Оно позволяет проектировать системы на наноуровне посредством многоуровневого моделирования при стремительном увеличении объемов обрабатываемой информации.

Наряду с этим получат широкое распространение проектно-конструкторские комплексы в энергомашиностроении при моделировании структуры, свойств конструкций и материалов в экстремальных условиях, системах управления жизненным циклом сложных инженерных объектов и т. д.

На базе выявленных механизмов физиологии человека, включая процессы, интегрирующие биологические и алгоритмические способы обработки информации, к 2020-2030 гг. появятся коммерческие приложения, основанные на эффектах виртуальной и расширенной реальности, использующие весь комплекс каналов восприятия информации человеком.

\section{Технологии инженерии знаний}

На стыке теории обучающихся систем, когнитивной психологии и исследований в области искусственного интеллекта получили развитие алгоритмы и методы инженерии знаний. Последняя распространяет понятия, которые в разработках по искусственному интеллекту относились лишь к компьютерам (machine learning), на любую обучающуюся систему (learning system). Проблема «больших данных» усиливается необходимостью управления колоссальными объемами разноформатной неструктурированной информации, не вписывающейся в традиционный формат. Это сформирует спрос на инструменты для установления взаимосвязей между данными и получения на их основе значимых выводов. Ожидаемая высокая динамика технологий связана с тем, что изменения средств обработки информации, обусловленные проблемой «больших данных» и появлением новых аналитических инструментов (next-generation business intelligence) ${ }^{12}$,

\footnotetext{
${ }^{11}$ Ситуацию на мировом рынке в этой области характеризуют поглощения компаний SPSS и Business Objects cooтветственно корпорациями IBM и SAS и регулярное проведение международной конференции «Predictive Analytics World», посвященной приложениям предсказательной аналитики для бизнеса.

${ }^{12}$ Средства формализации и гармонизации знаний, персональные аналитические системы, инструменты аналитики для работы с неструктурированными данными (в том числе для мобильных устройств).
} 
заставляют ИКТ-компании оперативно воплощать их в продукты и услуги для получения конкурентного преимущества.

Появление программных систем извлечения и формализации знаний из неструктурированной и слабоструктурированной информации. Повышению эффективности работы с «большими данными» будут способствовать совершенствование технологий высокопроизводительного семантического анализа, создание аппаратно-программных платформ, учитывающих специфику семантических баз данных и формирования баз знаний.

Разработаны первые высокопроизводительные системы, осуществляющие такой анализ, в том числе в реальном времени, на принципах модели распределенных вычислений MapReduce, предложенной Google и распространенной в решениях с открытыми кодами Hadoop. Потенциальными сферами их применения являются бизнес-аналитика, биоинформатика, медицина, телекоммуникации, логистика, анализ социальных сетей, поисковые системы. В США рынок семантических баз данных оценивается в десятки миллиардов долларов [Read, 2012].

В России становление рынка систем формализации знаний откроет новые возможности снижения и предотвращения загрязнения окружающей среды, переработки и утилизации техногенных образований и отходов, экологически безопасной разработки месторождений и добычи природных ресурсов, снижения риска природных и техногенных катастроф. Это стимулирует спрос на специалистов новых профилей: экспертов в области алгоритмов работы с «большими данными» (data scientist), архитекторов семантических баз данных и знаний (data architect), проектировщиков пользовательских запросов и специалистов, способных учитывать опыт пользователей (user experience designer).

Возникновение систем машинного обучения, основанных на новых методах и алгоритмах. Системы «машинного обучения» (machine learning) выявляют закономерности в содержимом баз данных (по «обучающим выборкам»). Они позволят классифицировать объекты с целью визуализации, кластеризации и прогнозирования поведения потребителей (автоматизации маркетинговых исследований, формирования адресных предложений, персонализации сервисов, повышения удовлетворенности и лояльности клиентов, эффективности их привлечения и удержания и др.).

Подобный подход сможет активно применяться и в ряде других приложений, в частности при разработке самообучающихся систем машинного перевода, использующих языковые соответствия между самим текстом и прецедентами результатов перевода.

Создание эффективных форм визуализации информации, контента и знаний. Процесс формирования знаний опирается на интуитивные механизмы мышления, а сами знания приобретают субъективный, экспертный характер. Их эффективная формализация в образовании и поиске нестандартных решений опирается на новые механизмы мотивации к обучению и самообучению (в том числе на базе технологий дополненной реальности и когнитивной компьютерной графики). Достаточно активно развивается рынок визуализации научной информации.

Конвергенция индустрий компьютерных игр, мобильного контента, кинопроизводства, учреждений культуры проявится в создании социальных вебсервисов, использующих потоки мультимедийных данных и новые устройства отображения информации.

В течение 10-20 лет можно ожидать значительного снижения стоимости и роста рынка встроенных портативных мультимедийных проекторов; дисплеев, гибко программируемых под конкретные задачи; панелей для взаимодействия с людьми в общественных местах; устройств отображения на легких дисплеях, надеваемых на голову или использующих прямое нейронное подключение; ультратонких мониторов, электронной бумаги и т. п. (технологии OLED и OLEP) [Калин, 2010].

B ближайшем будущем качественно улучшится отображающая способность дисплеев, что - в интеграции с оперированием «большими данными»повлечет за собой создание аппаратно-программных систем визуализации и построение сложных трехмерных сцен по изображениям и видеоряду в режиме реального времени. А это - основа для формирования комплексных моделей операционной обстановки автоматизированных рабочих мест для различных видов профессиональной деятельности.

Развитие программных систем принятия решений и идентификации ситуаций, репозитории открытых данных (linked open data). Примерно в 2020-2025 гг. лидерами на рынке станут: программные системы поддержки принятия решений, синтезирующих поиск и интеллектуальный анализ данных и знаний, моделирования рассуждений на базе прецедентов, имитационного моделирования, эволюционных вычислений, генетических алгоритмов, нейронных сетей, когнитивного моделирования. Они будут использоваться как для решения задач бизнеса, так и в сфере государственного управления.

Поиск и систематизация информации, размещаемой в репозиториях открытых данных, уже становятся привлекательным рынком услуг для частного сегмента ИКТ-индустрии. С расширением взаимосвязей между хранилищами на основе существующих Webтехнологий резко снизится избыточность хранящихся в них информации и знаний на всех уровнях государственного и муниципального управления, что позволит оперативно обновлять открытые данные.

Решение проблем семантической интероперабельности и глобальной идентификации объектов. К 2020 2025 гг. благодаря взаимодействию международных организаций и консорциумов по формированию комплекса открытых стандартов решится задача достижения и поддержания интероперабельности информационных инфраструктур категорий «облачные вычисления» (cloud) и «ИКТ-инфраструктуры сверхвысокой пропускной способности» (grid) ${ }^{13}$. В итоге повысится эффективность процессов цифровизации контента за счет

\footnotetext{
${ }^{13}$ Примером реализации модели консорциума для решения комплекса проблем интероперабельности служит деятельность глобального альянса Ореп Group. Его участниками стали более 400 компаний из разных стран, включая Россию (режим доступа: http://www.opengroup.org/, дата обращения 05.06.2012).
} 
его персонализации, оперативного взаимодействия потребителей с производителями и поставщиками, что стимулирует распространение интероперабельных сетевых решений для «Интернета вещей».

Прежде национальные системы электронного документооборота базировались на общих рекомендациях OOH, ISO, BTO и функционировали (как правило, разрозненно) в локальных либо ведомственных корпоративных сетях (транспорт, таможня, страхование и т. д.). Однако максимальный эффект от системы электронных транзакций может быть достигнут только при условии взаимодействия корпоративных и ведомственных систем. Последнее будет обеспечено формируемой глобальной системой GSI, базирующейся на технологиях радиочастотной идентификации (RFID) ${ }^{14}$, с помощью которых социальные структуры в Интернете будут интегрированы с инфраструктурными сервисами («умный город», «виртуальные предприятия» и т. п.). Сближение технологий Web 2.0 и сервисных архитектур породит новые модели бизнеса, совместного использования информации и социальных сетей на базе «Интернета сервисов» (Internet of Services, IoS). B более долгосрочной перспективе технологии массового производства идентификационных меток, средства разработки и тестирования ПО сетевых архитектур приведут к полноценной интеграции «Интернета людей», «Интернета вещей» и «Интернета сервисов».

\section{Адаптивные технологии создания информационных систем}

Экономика, основанная на знаниях, сочетает ценности и интересы как сферы создания идей, технологий и контента, так и индустриального производства. Концепция «умного предприятия» предполагает виртуальное объединение структур и процессов адаптивными информационными связями и общим комплексом стандартов, которые вырабатываются в результате совместной деятельности распределенных центров компетенций [Missikoff, De Panfilis, 2012]. Такая модель обладает важным для инновационной экономики свойством масштабируемости (scalability). При увеличении числа участников рынка и объема используемых ими производственных ресурсов после прохождения критической отметки отдача не снижается (как в случае традиционной экономики), а повышается.

По мере усиления конвергенции трех составляющих ИКТ - компьютеров, коммуникаций и контента будут стремительно развиваться новые технологии создания информационных систем и их приложения (сенсорные сети, работа с пространственными данными, транспортные средства нового поколения, робототехника и т. п.).

Появление новых принципов, моделей и процессов управления большими системами. Реализация модели «умного предприятия» тесно связана с концепцией «Интернета вещей». Ожидается, что к 2020 г. к сети Интернет будет подключено порядка 100 млрд устройств различного назначения [Velev, 2011, и др.]. Значительную долю клиентов такого охвата будут составлять «вещи» - специализированные устройства, располагающие минимальными по современным нормам процессорными ресурсами и входящие в состав сенсорных сетей. Интеграция последних с мобильными автономными роботами существенно снизит риски, возникающие в сложных и особо опасных производственных процессах. Прогресс технологий сенсорных сетей содействует переходу к новым уровням чувствительности и точности цифровых сенсоров, вследствие чего повышается качество и оборудования, и готовой продукции.

Среди перспективных направлений применения ИКТ в сфере материального производства выделяются: синтез инструментов со средствами производства (станки, приборы, технологическое оборудование); интеграция локальных информационно-управляющих систем с применением сетевых технологий; снижение материало- и энергоемкости продукции; формирование глобальных цепочек создания стоимости; освоение продукции со встраиваемыми информационно-коммуникационными средствами.

К 2025 г. рынок инструментов автоматизации и систем управления производством станет в полной мере «сетецентричным» и интегрируется в сферу ИКТ. Для реализации стартового потенциала «Интернета вещей» на уровне однозначной идентификации последних потребуется трансформация производственных процессов в большинстве секторов экономики. Повсеместное применение меток RFID и сетей, в которых производственное оборудование, транспортные, складские и иные материальные объекты получат собственные IP-адреса, переведет работу промышленных предприятий в режим «жесткого реального времени». В более отдаленной перспективе будет организована глобальная идентификация субъектов и объектов экономической деятельности (e-ID) в новой парадигме информационной безопасности ${ }^{15}$ и получат развитие информационные сервисы на основе инфраструктуры пространственных данных (услуги, учитывающие местоположение пользователя (location-based services, LBS).

Активизируется спрос на средства ИКТ и в сфере грузовых перевозок. Продолжится экстенсивное внедрение интеллектуальных транспортных систем. С расширением глобальной торговли увеличатся масштабы применения логистических систем управления мультимодальными перевозками грузов и пассажиров. Получат развитие инновационные средства сбора данных (в том числе голосовой и RFID-пикинг ${ }^{16}$ ), управления транспортом и логистикой с помощью инфраструктур пространственных данных (движение транспорта, оптимизация расхода энергии и топлива и т. п.). Новые методы транспортного моделирования, прогнозирования и планирования дадут толчок распространению расчетов транспортно-экономических

\footnotetext{
${ }^{14}$ Технология RFID предполагает передачу с помощью радиоволн информации, необходимой для распознавания объектов, на которых закреплены специальные метки, содержащие как идентификационные, так и пользовательские данные.

${ }^{15}$ Развитие этого направления координируется глобальным консорциумом World e-ID (режим доступа: http://www.worlde-idcongress.com/, дата обращения 16.08.2013).

${ }^{16}$ Пикинг - сбор заказов клиентов в логистических инфраструктурах.
} 
балансов и оптимизации транспортной инфраструктуры.

Защита компьютерных инфраструктур на основе принципиально новых парадигм. Адекватной реакцией на расширение источников угроз становится смена парадигмы информационной безопасности переориентация с «защищенности» на «развитие». Конвергенция телекоммуникаций наряду с распространением социально значимых ИКТ-сервисов (e-banking, e-voting, e-booking, e-application forms и т. п.) актуализировала проблемы идентификации, аутентификации и электронной цифровой подписи. Получат распространение новые поколения сетевых протоколов, специфичных для «Интернета вещей», средства квантовой криптографии и нейрокогнитивные методы обеспечения информационной безопасности. В сочетании с технологиями облачных вычислений они значительно усовершенствуют механизмы выполнения трансакций, базирующиеся на надежной идентификации и аутентификации клиента (как в частной жизни, так и в бизнесе и государственном управлении).

Развитие инновационных подходов к энергосбережению с широким применением ИКТ (smart grid, активно-адаптивные сети). Принятое сегодня определение «smart grid» характеризует концепцию «полностью интегрированной, саморегулируемой и самовосстанавливающейся электроэнергетической системы, имеющей сетевую топологию. В нее входят все генерирующие источники, магистральные и распределительные сети и все виды потребителей электрической энергии, управляемые единой сетью автоматизированных устройств в режиме реального времени» [IEEE, 2013, p. 8]. Учитывая роль энергетической инфраструктуры в экономике любой страны, можно сделать вывод о системообразующей роли ИКТ-продуктов этой категории. Среди факторов динамичного роста спроса на них следует выделить повышение эффективности технологий математического моделирования и оптимизацию перспективных энергетических технологий и систем, в частности, для прогнозирования и управления.

Значительный вклад в функционирование систем smart grid (с точки зрения оптимизации работы электрической сети) вносят сенсоры, которые обрабатывают информацию, составляют прогнозы и временно отключают некритичное оборудование для экономии энергии [Bartels, 2009].

Распространение сенсорных сетей. В текущем десятилетии перспективными направлениями использования сенсоров в системных решениях станут «умные» энергетические сети; интеллектуальное управление транспортными потоками; технологии «умного дома»; мониторинг природных и агропромышленных комплексов. Высокий потенциал имеет, например, развитие концепции «сетевого» автомобиля, в котором интегрированы услуги навигации, связи и обмена информацией с другими автомобилями [Минобрнауки России, 2010].

В мировой практике накоплен опыт реализации проектов «умных» инфраструктур: «London congestion charging system» (автоматическое наложение штрафов на владельцев автомобилей, въезжающих в центр Лондона по будням); система «I-35 Bridge» в Мин- неаполисе (Миннесота, США), состоящая из нескольких сотен датчиков для считывания разнообразных показателей - от коррозии до температуры [Bartels, 2009]; "Air Traffic Management Solutions for the Single European Sky» (SESAR) или «River Information Services» (RIS) [European Commission, 2010b], демонстрирующие возможности ИКТ в оптимизации функционирования воздушного и речного транспорта.

Повсеместное внедрение сенсорных сетей в различных секторах экономики может в долгосрочный период по своим позитивным последствиям превзойти эффект распространения Интернета и кардинально изменить роль человека в производственных процесcax: взаимодействие элементов таких сетей, связанных с объектами, становится проактивным, предвосхищающим управляющие воздействия человека-оператора. В последующем подобные сети приобретут сложную (и даже, возможно, произвольную) конфигурацию, высокую отказоустойчивость, масштабируемость, а в более отдаленной перспективе - способность к самоорганизации.

Появление интеллектуальных роботизированных систем, способных к адаптивному коллективному поведению. Ожидается интеграция функциональных возможностей беспроводных сенсорных сетей с потенциалом мобильных автономных средств робототехники на основе изучения алгоритмов индивидуального и коллективного поведения интеллектуальных роботов и моделей принятия решений в биологических структурах (нейроморфные вычисления) [Минобрнауки России, 2010]. В долгосрочной перспективе она организует деятельность групп мобильных роботов при отсутствии централизованного управления.

Исследования в этой области касаются анализа совокупной реакции на непредсказуемую динамику внешней среды, неполноту и противоречивость информации о ее состоянии и поведении других участников группы; вариантов достижения цели; распределения ролей в группе и т. д. Перспективным направлением являются и виртуальные роботы (аватары) для общения с пользователями по определенной тематике [Калин, 2010]. Прогнозируется, что роботы вытеснят человека из процессов создания информационного и развлекательного контента, ввиду их большей способности к интерактивному взаимодействию.

\section{Технологии распределенных и параллельных вычислений}

Комплексные услуги в сфере распределенных и параллельных вычислений (метакомпьютинг), использующие программные продукты большого объема, найдут применение в ряде секторов (биотехнологии, новые материалы, технологии энергосбережения и т. п.). Расширение функциональных характеристик ПО, продление его жизненного цикла, учет специфики систем и внешней среды, в которой оно используется, приведет к повышению эффективности услуг.

Рост реальной производительности аппаратных платформ метакомпьютинга будет достигаться за счет новых способов решения проблем энергопотребления, увеличения времени наработки компонентов на отказ и параллелизма, создания совокупности типовых 
архитектур платформ для инфраструктуры услуг, предоставляемых этой технологией.

Появление архитектур сетей, реализующих новые принципы организации. Решения на базе инфраструктур grid-сетей послужат созданию приложений как в сфере перспективных технологий (нано-, биотехнологии, технологии атомной и альтернативной энергетики, модели управления энергопотоками), так и в массовых социально значимых сегментах рынка ИКТсервисов (транснациональные системы непрерывного образования, ИКТ-сервисы для многоуровневых социальных структур категории «е-government», а также для малых и средних инновационных предприятий).

На существующем уровне технологии grid-сетей поддерживаются слабосвязанными крупными конфигурациями компьютеров с несколькими доменами административного управления, значительной степенью автономии, масштабируемостью и неоднородностью ресурсов. С постепенным переходом от модели владе ния материальными ИКТ-активами (asset ownership) к модели ИКТ-сервисов (service provisioning) будет сформирована база для раскрытия потенциала этих технологий и - в долгосрочной перспективе - конвергенции grid-сетей, Web-сервисов и семантических технологий; интенсивного развития сервис-ориентированных архитектур, обеспечивающих интеграцию массовых сервисов, включая те, что относятся к категории «Интернета вещей» ${ }^{17}$.

Создание гипермасштабируемых центров обработки данных для облачных Web-приложений, контентцентричные архитектуры сетей. В развитых странах в ближайшие 5-7 лет для облачных веб-приложений будут создаваться гипермасштабируемые центры обработки данных (ЦОД), однородные по составу оборудования, с десятками тысяч серверов, способных поддерживать работу многочисленных виртуальных машин.

В дальнейшем предполагается объединять инфраструктурные ресурсы каждого узла либо модуля гипермасштабируемых ЦОД в единую микросхему (концепция «сервер на чипе»). Долгосрочной тенденцией в хранении данных является полный отказ от механических компонент (присутствующих в накопителях на дисках).

На уровне аппаратно-программных платформ для ИКТ-сервисов разных уровней сложности уже реализуются (и довольно успешно) подсистемы контроля доставки приложений и средства их оптимизации и акселерации. Они анализируют состояние серверов и функционирующих на них приложений (сервисов), ускоряют работу последних, выполняют балансировку трафика и приложений на локальном (между серверами) и глобальном уровнях, управляют пропускной способностью каналов связи. В результате компанияпровайдер обеспечивает заданный уровень доставки приложений и сервисов и предлагает качественные услуги без увеличения затрат на серверные мощности.
Рост «тяжелого» трафика и усиление конкуренции на рынке широкополосного доступа в ближайшие годы могут привести к активной миграции провайдеров на оптоволоконные каналы, обеспечивающие работу растущего количества приложений.

Реализация концепции e-science (grid-вычисления, виртуальные установки и лаборатории). Развитие платформ для параллельной обработки информации в сетях цифровых устройств, содержащих более 1 млрд узлов при скоростях обмена между ними в диапазоне от 1Гбит/с до 1Тбит/с, на базе услуг метакомпьютинга категории e-science будет способствовать снижению порога входа стартапов на рынок наукоемких продуктов в таких секторах, как микроэлектроника, фармацевтика, проектирование новых материалов, биоинженерия.

В долгосрочной перспективе магистральные каналы в ИКТ-инфраструктурах метакомпьютинга мигрируют на оптоволоконную линию сверхвысокой пропускной способности, вырастут эффективность организации межузловых соединений и устойчивость совместной работы сетей и средств хранения данных. В итоге получит поддержку сложная структура сервисов, возникнут стандартные механизмы внешнего регулирования и метрики качества предоставления этих сервисов, что многократно улучшит технико-экономические характеристики аппаратных платформ, алгоритмов распределенных и параллельных вычислений, а также соответствующего ПО.

Развитие метакомпьютинга идет в русле общего тренда «зеленых технологий». Увеличение количества ядер и рост частоты повышает тепловыделение процессоров в составе серверных платформ. Перспективные системы полностью исключат промежуточное воздушное охлаждение, значительно повысив плотность вычислительных ресурсов. В будущем появятся многоядерные процессоры для метакомпьютинга со сверхмалым потреблением энергии.

Реализация методов верификации больших программ для облачных и grid-приложений. В среднесрочный период прогресс технологий разработки ПО пойдет по пути совершенствования методов верификации промышленных программно-аппаратных систем. Уже разработаны и апробированы теоретические основы алгоритмов, обеспечивающих эффективную верификацию ${ }^{18}$. В обозримом будущем эти методы станут частью технологического цикла компаний, создающих программы для критических применений.

В ряде случаев технологии верификации актуальны не только для крупных программных систем, но и для сокращения сроков разработки разнообразных приложений среднего уровня сложности, к надежности которых предъявляются особо высокие требования. Пример тому - встраиваемые компьютерные технологии для бортовых систем управления космических аппаратов, военной техники, мобильных телефонов, медицинской аппаратуры и др.

\footnotetext{
${ }^{7}$ Ведущие позиции в сфере исследований и разработок grid-сетей занимают страны ЕС. Значительную роль в этом играет Еuropean Grid Initiative (EGI), предусматривающая создание единой инфраструктуры для всех европейских исследовательских сообществ и их партнеров с других континентов на базе «бесшовной» интеграции существующих grid-систем и инфраструктур (режим доступа: www.eu-egi.eu, дата обращения 19.07.2013).

${ }^{18}$ Метод проверки модели (model checking) сводится к исчерпывающему анализу всего пространства состояний модели и не требует доказательств теорем на основе формальных аксиом алгебры, арифметики и правил вывода, характерных для классических подходов, что полностью автоматизирует верификацию.
} 
Решение крупномасштабных вычислительных задач. Магистральной тенденцией в разработке суперкомпьютерных систем для крупномасштабных вычислений является создание кластеров (массовопараллельных систем) серверов с процессорами, имеющими большое количество процессорных ядер, с целью масштабирования пиковой производительности. Для самых востребованных классов вычислительных задач (численные методы, моделирование, задачи молекулярной динамики и т. п.) производительность процессорных ядер достигается не столько за счет увеличения тактовой частоты, сколько выполнением большего числа операций с плавающей запятой за один такт процессора.

Перспективными инструментами, активно используемыми при высокопроизводительных вычислениях, стали графические процессоры (graphical processing unit, GPU), отличающиеся высокими техническими характеристиками и возможностью снижения стоимости их производства на фоне массового спроса. В ближайшие 15 лет подобные системы «научатся» решать задачи из таких областей, как компьютерная алгебра, интеллектуальные системы, моделирование сложного поведения и др., которые требуют высокой производительности оборудования и обработки нечисловых данных либо информации, имеющей сложное представление (динамически порождаемые списки, деревья, графы и т. п.). Расширится спектр специализированных однокристальных процессоров, применяемых в комплексах высокопроизводительных вычислений с неоднородной архитектурой.

Как видим, реализация отмеченных технологических направлений станет важнейшим драйвером практически для всех секторов экономики. В табл. 1 систематизированы принципиально новые продукты и услуги, которые в массовом порядке появятся на рынке в период до 2030 г.

\section{Табл. 1. Важнейшие перспективные тренды, продукты и услуги в секторе ИКТ}

\begin{tabular}{|c|c|}
\hline Тренды & Продукты и услуги \\
\hline $\begin{array}{l}\text { Рост влияния ИКТ на социальные про- } \\
\text { цессы в обществе, развитие человека, } \\
\text { появление новых форм социализации } \\
\text { и социального взаимодействия }\end{array}$ & $\begin{array}{l}\text { Общедоступные системы автоматизированного обучения для отдельных пред- } \\
\text { метов и специальностей; средства создания виртуальных профессиональных } \\
\text { сообществ и новых форм занятости }\end{array}$ \\
\hline $\begin{array}{l}\text { Развитие рынка мобильных и социаль- } \\
\text { ных приложений, игр с высоким рыноч- } \\
\text { ным потенциалом }\end{array}$ & $\begin{array}{l}\text { Алгоритмы, устройства и ПО для персонализации контента и технологий до- } \\
\text { полненной реальности }\end{array}$ \\
\hline $\begin{array}{l}\text { Вовлечение граждан в управление (citizen } \\
\text { dashboards, e-democracy) }\end{array}$ & $\begin{array}{l}\text { Алгоритмы, устройства и ПО для работы с пространственными данными } \\
\text { (location-based services) и обеспечения информационной безопасности (препят- } \\
\text { ствуют попыткам деятельности, противоречащей этике поведения в цифровых } \\
\text { сетях) }\end{array}$ \\
\hline $\begin{array}{l}\text { Превращение ИКТ в значимый фактор } \\
\text { повышения качества жизни людей с огра- } \\
\text { ниченными возможностями }\end{array}$ & $\begin{array}{l}\text { Алгоритмы и ПО для трехмерного моделирования в задачах биомедицинской } \\
\text { инженерии, использования больших массивов цифровых биомедицинских } \\
\text { данных, интонационного синтеза речи высокого качества }\end{array}$ \\
\hline $\begin{array}{l}\text { Развитие технологий для персонализиро- } \\
\text { ванной медицины }\end{array}$ & $\begin{array}{l}\text { Носимые беспроводные датчики; единые электронные идентификационные } \\
\text { документы (социальные и медицинские карты); системы круглосуточного } \\
\text { мониторинга важнейших физиологических параметров человека }\end{array}$ \\
\hline $\begin{array}{l}\text { Распространение интегрированных сис- } \\
\text { тем предупреждения рисков для здоровья }\end{array}$ & $\begin{array}{l}\text { Методы, алгоритмы и ПО для удаленного мультимедийного общения через } \\
\text { публичные сетевые ресурсы с эффектом присутствия }\end{array}$ \\
\hline $\begin{array}{l}\text { Расширение возможностей применения } \\
\text { ИКТ в интересах охраны окружающей } \\
\text { среды и снижения негативного воздей- } \\
\text { ствия производства на природу и чело- } \\
\text { века }\end{array}$ & $\begin{array}{l}\text { Алгоритмы и ПО оценки рисков и планирования мероприятий по преодоле- } \\
\text { нию чрезвычайных ситуаций в транспортных, коммуникационных и энергети- } \\
\text { ческих инфраструктурах }\end{array}$ \\
\hline $\begin{array}{l}\text { Сохранение культурного наследия } \\
\text { в электронной форме }\end{array}$ & $\begin{array}{l}\text { Мультиструктурные и мультимодальные поисковые системы и хранилища } \\
\text { информации; алгоритмы и ПО для организации гигантских электронных } \\
\text { библиотек }\end{array}$ \\
\hline $\begin{array}{l}\text { Появление средств предсказательно- } \\
\text { го моделирования систем и объектов; } \\
\text { создание моделей прогнозирования на } \\
\text { основе данных, поступающих в реальном } \\
\text { времени }\end{array}$ & $\begin{array}{l}\text { Алгоритмы и ПО для моделирования физических, химических и биологиче- } \\
\text { ских процессов, достоверно прогнозирующие результаты междисциплинар- } \\
\text { ных экспериментальных исследований }\end{array}$ \\
\hline $\begin{array}{l}\text { Радикальное сокращение сроков и } \\
\text { стоимости проектирования, повышение } \\
\text { качества продукции благодаря использо- } \\
\text { ванию метамоделей }\end{array}$ & $\begin{array}{l}\text { Алгоритмы и ПО систем и комплексов предсказательного моделирования со- } \\
\text { циальных, техногенных, климатических, сейсмических, геофизических и т. п. } \\
\text { явлений }\end{array}$ \\
\hline $\begin{array}{l}\text { Развитие новых технологий ресурсоемко- } \\
\text { го компьютерного моделирования мате-- } \\
\text { риалов и процессов }\end{array}$ & $\begin{array}{l}\text { Алгоритмы и ПО компьютерного мониторинга и прогнозирования особо } \\
\text { опасных климатических изменений }\end{array}$ \\
\hline $\begin{array}{l}\text { Появление моделей развития инноваци- } \\
\text { онного бизнеса (в том числе «разрушаю- } \\
\text { щих» инноваций) }\end{array}$ & $\begin{array}{l}\text { Развитие ИКТ-сервисов предсказательного моделирования социально-эконо- } \\
\text { мических явлений }\end{array}$ \\
\hline $\begin{array}{l}\text { Появление целостных программных } \\
\text { комплексов для решения задач про-- } \\
\text { ектирования, конструирования, моде-- } \\
\text { лирования и инжиниринга сложных } \\
\text { технологических объектов и систем }\end{array}$ & $\begin{array}{l}\text { Разработка метаматериалов и ПО для обработки и передачи изображений } \\
\text { со сверхразрешением; устройства трехмерного отображения информации } \\
\text { в объемах до } 1000 \text { м }^{3}\end{array}$ \\
\hline $\begin{array}{l}\text { Развитие программных систем принятия } \\
\text { решений и идентификации ситуаций на } \\
\text { основе сверхбольших массивов и пото- } \\
\text { ков данных, развитие репозиториев от- } \\
\text { крытых данных (linked open data) }\end{array}$ & Аналитическое ПО нового поколения (next generation analytics) \\
\hline
\end{tabular}




\section{Тренды}

Развитие мультиязычных и мультимодальных систем управления знаниями

Сокращение отставания методов и средств обработки и анализа информа ции от темпов роста объемов информации

Решение проблем семантической интер операбельности и глобальной идентифи кации объектов

Создание эффективных форм визуализации информации, контента и знаний

Создание систем машинного обучения (machine learning), основанных на новых методах и алгоритмах

Моделирование человеческого интеллекта, когнитивные модели сознания и поведения

Новые человеко-машинные интерфейсы

«Умные инфраструктуры»

Использование более экономичных и гибких моделей ИТ-инфраструктуры

Появление новых принципов, моделей и процессов управления большими системами (социально-экономическими, техническими, транспортными и т. д.)

Создание виртуальных офисов без снижения эффективности коллективной дея тельности компаний, предприятий и др.

Развитие инновационных подходов к энергосбережению с широким применением ИКТ (smart grid, активно-адаптивные сети)

Развитие средств автоматизированного формирования материальных объектов на основе цифровых моделей этих объектов

Снижение энергозатрат при передаче и хранении информации («зеленые» ИKT

Защита компьютерных инфраструктур на основе принципиально новых парадигм

Появление интеллектуальных роботизированных систем, способных к адаптивному коллективному поведению

Распространение сенсорных сетей для промышленных применений, интеграция сенсорных сетей и мобильных автономных средств робототехники

Новые принципы организации вычисле ний, создания вычислительных архитектур, построенных на новых парадигмах

Перспективные языки и системы программирования, реализующие новые парадигмы

Высокопроизводительные ЦОД

Реализация методов верификации (проверки правильности) больших программ для облачных и grid-приложений

Появление архитектур сетей, реализующих новые принципы организации

\section{Продукты и услуги}

Алгоритмы и ПО для формализации и извлечения знаний из слабоструктурированной и неструктурированной информации

Методы, алгоритмы и ПО для сбора и анализа «больших данных»

Алгоритмы и ПО для обработки мультимедийной информации в сетях хранения на основе распараллеливания операций выявления семантических связей

Устройства и ПО для работы со сценами виртуальной и дополненной реальности; реализация методов виртуального погружения

Алгоритмы и ПО машинного обучения (machine learning), в том числе с опорой на суперкомпьютерные модели распределенных вычислений; алгоритмы и ПО для самообучающихся систем машинного перевода

Алгоритмы и ПО для построения сложных трехмерных сцен по изображениям и видеоряду в режиме реального времени; адаптивные информационные системы, основанные на бесконтактном взаимодействии «мозг-компьютер»

Алгоритмы и ПО для распознавания слитной устной речи; методы, алгоритмы и ПО для персонализации и защиты информации, находящиеся под контролем пользователя и не зависящие от устройства доступа; унификация / консьюмеризация абонентских устройств

Алгоритмы и ПО интеллектуальных транспортных систем; устройства и ПО для идентификации и аутентификации субъектов и объектов экономической деятельности (е-ID); «умные» энергетические сети

Миграция магистральных каналов на волоконно-оптические линии связи; оптические процессоры для работы в магистральных коммуникационных каналах; ИКТ-сервисы для М2М-инфраструктур

Алгоритмы и ПО мониторинга инфраструктур энергообеспечения и промышленных предприятий

Алгоритмы и ПО для интеграции ИКТ-сервисов, представляемых через Интернет (включая различные виды аутсорсинга), в процессы деятельности организаций; технологии краудсорсинга в бизнес-процессах

Автономные необслуживаемые микромощные радиоэлектронные устройства, программируемые по радиоканалу; цифровые устройства, обладающие свойствами репликации и/или самовосстановления

Методы и средства «искусственного эмбриогенеза» - кодирования процесса поэтапной самоорганизации искусственных материалов и конструкций

Компактные источники энергии для долговременного питания цифровых устройств массового применения; фотонные устройства и компоненты; многоядерные процессоры со сверхмалым потреблением энергии

Надежные биометрические устройства идентификации личности; алгоритмы, устройства и ПО криптозащиты данных, устойчивой к вычислениям на гипотетическом квантовом компьютере

Алгоритмы и ПО для организации коллективного поведения в сообществах взаимодействующих роботов

Сенсорные сети промышленного применения для встраиваемых средств ИКТ; инфраструктуры широкополосных беспроводных и специализированных сенсорных сетей

Алгоритмы и ПО для параллельной обработки информации в сетях цифровых устройств, содержащих более $10^{9}$ узлов

Инструментальные средства разработки, отладки и тестирования программ для различных классов систем параллельных вычислений

Гипермасштабируемые ЦОД для облачных Web-приложений; контентцентричные архитектуры сетей

Методы, алгоритмы и системы для проверки и тестирования ПО, создающие возможность разработки крупных и свободных от ошибок программных проектов

Алгоритмы и ПО для реализации когнитивных, гибридных и адаптивных сетевых архитектур

Источник: ИСИЭЗ НИУ ВШЭ. 


\section{Приоритетные направления научных исследований в сфере ИКТ}

В рамках долгосрочного прогноза научно-технологического развития были выявлены стратегические направления развития задельных исследований в сфере ИКТ, создающие основу для производства в среднеи долгосрочной перспективе (за пределами 2020 г.) инновационных продуктов и услуг и формирования на этой основе новых рынков [НИУ ВШЭ, 2013b]. Всего были выделены семь масштабных направлений, детализированных в виде нескольких десятков узких областей исследований. Их состав и результаты, которые могут найти практическое использование в самых разных областях экономики и социальной сферы, приведены в табл. 2.

\section{Заключение}

Проведенный анализ позволяет заключить, что сектор ИКТ в средне- и долгосрочной перспективе сохранит высокие темпы динамики и будет оказывать мощное воздействие на развитие бизнеса и государствен ного управления, рост качества жизни, появление новых форм социализации людей и их коммуникации. Жизненный цикл технологий, соответствующих продуктов и услуг будет только ускоряться. В этих условиях крайне значимой остается роль научных ис следований и разработок.

Среди результатов, ожидаемых в период до 2030 г., прототипы систем, реализующих новые принципы организации вычислений, и мультиязычных программ извлечения и формализации знаний; технологии для работы с гигантскими массивами данных; новые аналитические инструменты (персональные аналитические системы, средства обработки данных, поступающих в режиме реального времени, мобильной аналитики и др.).

Российские ученые в значительной части указанных областей имеют определенные заделы, что, однако, не позволяет говорить о мировом лидерстве. Прорывной

\section{Табл. 2. Перспективные направления задельных исследований в сфере ИКТ}

Направления исследований

\section{Ожидаемые результаты}

\section{Компьютерные архитектуры и системы}

- Экзафлопсные суперЭВМ

- Вычислительные алгоритмы и программное обеспечение для систем сверхвысокой производительности

- Распределенные системы и архитектуры

- Новые архитектуры серверных и персональных компьютерных устройств

- Новые парадигмы организации и реализации вычислительных процессов, технологии создания компьютерных устройств

- Технологии передачи информации - Технологии организации сетей

- Технологии распространения контента

- Технологии и системы цифровой реальности и перспективные интерфейсы взаимодействия человека и ИКТ
- Прототипы систем, реализующих новые принципы организации вычислений

- Прототипы элементов вычислительных систем, реализующих перспективные принципы сопряжения, хранения и информационного обмена

- Исследовательские модели и прототипы компонентов вычислительных архитектур, построенных на новых парадигмах (в том числе нейро-, био-, оптических, квантовых), системы самосинхронизации, рекуррентности

\section{Телекоммуникационные технологии}

- Прототипы сетей и элементов коммуникационных инфраструктур с терабитовыми скоростями передачи информации

- Прототипы сетей, реализующих новые принципы организации, в том числе когнитивных, гибридных, адаптивных реконфигурируемых, гетерогенных

- Прототипы систем с гарантированным динамическим выделением ресурса

- Прототипы исследовательских сетей нового поколения, обеспечивающих передачу больших объемов данных, получаемых в результате научных экспериментов, распределенную обработку научной информации, совместную работу распределенных научных групп

Технологии обработки и анализа информации

- Методы и технологии сбора, обработки, анализа и хранения сверх больших объемов информации

- Технологии работы с мультимедийной информацией

- Технологии работы с текстовой и слабоструктурированной инфор мацией

- Web-технологии и системы

- Технологии анализа информации
- Прототипы мультиязычных программных систем извлечения и формализации знаний из неструктурированной и слабоструктурированной информации, а также перспективных средств хранения и анализа знаний

- Прототипы, основанные на новых принципах программных систем обработки, поиска, анализа и визуализации, в том числе программные системы принятия решений и идентификации ситуаций на основе сверхбольших массивов и потоков данных

- Прототипы программных систем анализа сложных трехмерных сцен по изображениям и видеоряду в режиме реального времени

- Исследовательские модели и прототипы программных систем хранения, обработки и анализа сверхбольших мультикомпонентных потоков информации, в том числе медиаинформации

\section{Элементная база и электронные устройства, робототехника}

- Технологии автоматизированного проектирования элементной базы

- Использование новой элементной базы для создания перспективных ИКТ

- Технологии создания сложных функциональных блоков для элементной базы

- Робототехника
- Исследовательские и опытные образцы сложно-функциональных блоков интегральных схем с учетом качественно новых эффектов, в том числе взаимного влияния элементов и подложки

- Опытные образцы микропроцессоров и коммуникационных сверхбольших интегральных схем на основе самосинхронной логики с локально-асинхронными механизмами самоконтроля и парирования ошибок

- Прототипы элементной базы на основе квантовых эффектов, одноэлектроники, спинтроники и фотоники

- Прототипы биоподобных и антропоморфных робототехнических устройств, самообучающихся роботов, искусственных нервных систем роботов, систем группового управления роботами 


\section{Предсказательное моделирование, функционирование перспективных систем}

- Моделирование сложных систем и процессов

- Интеллектуальные системы управления и поддержки принятия решений

- Средства проектирования и поддержки функционирования ИКТ

- Прототипы программных систем предсказательного моделирования сложных систем (технических, социально-экономических, политических, транспортных и др.) и свойств физических, химических, биологических и других объектов с выходом на уровень предсказательной точности и сложности, не достижимый в настоящее время

- Прототипы программных систем, реализующих новые модели процессов в природе, обществе, гуманитарной сфере, киберпространстве и других областях

- Прототипы программных систем автоматизированного управления большими системами (социально-экономическими, техническими, транспортными и т. д.) на основе новых принципов, моделей и процессов управления

- Прототипы программных систем, в которых реализуются гибридные модели когнитивных механизмов и речемыслительной деятельности человека, технологии моделирования человеческого интеллекта

- Исследовательские модели и прототипы устройств с новыми принципами организации взаимодействия «человек - компьютер»

\section{Информационная безопасность}

- Технологии надежной идентифика-

- Надежные и доверенные архитектуры, протоколы, модели

- Технологии обеспечения защиты персональных данных

- Методы и средства биометрической идентификации личности

- Противодействие новым вызовам информационной войны и киберпреступности в сфере ИКТ ции и аутентификации в ИКТ

- Прототипы средств защиты компьютерных инфраструктур на основе принципиально новых парадигм, в том числе квантовой криптографии и компьютинга, нейрокогнитивных принципов

- Прототипы перспективных средств и программных систем защиты данных с учетом новых принципов организации информации и взаимодействия информационных объектов, в том числе глобальной интеграции информационных систем, повсеместного доступа к приложениям, новых протоколов Интернет, виртуализации, социальных сетей, данных мобильных устройств и геолокации

- Прототипы, основанные на новых принципах программных систем биометрической идентификации, обработки, интеграции и анализа мультимодальных биометрических данных, в том числе в целях их использования в новых областях (социальный Web; приложения, использующие геоконтекст; обеспечение сохранности имущества; игры и др.)

\section{Алгоритмы и программное обеспечение}

- Перспективные парадигмы и технологии программирования, языки и системы

- Технологии и решения для операционных систем, СУБД и ПО промежуточного слоя

- Когнитивные технологии
- Перспективные языки и прототипы систем программирования, реализующие новые и объединяющие существующие парадигмы, в том числе объектноориентированные, функциональные, логические, языки спецификаций, «программирование без программиста», предметно-ориентированные, программирование на естественном языке, с поддержкой доказуемости различных свойств программ

- Прототипы компонентов перспективного системного программного обеспечения, в том числе обеспечивающие повышение производительности обработки информации, достоверное доказательство выполнения требований, поддержку перспективных архитектур и др.

- Исследовательские модели и алгоритмы, адаптируемые к вычислительным системам нового поколения

- Прототипы программных систем, реализующих новые модели организации параллельных вычислений

- Прототипы программных систем, реализующих новые принципы распределенных вычислений на базе сети компьютеров и мобильных устройств частных владельцев;

- Прототипы программных и операционных систем с локально-асинхронными механизмами самоконтроля и парирования ошибок

- Исследовательские модели и прототипы автоматизированных и автоматических систем анализа программ (включая доказательство их различных свойств) и преобразования программ (включая оптимизацию по различным критериям, распараллеливание, инверсию, композицию и вывод новых программ из существующих)

- Исследовательские модели и прототипы программных систем машинного обучения, основанных на новых методах и алгоритмах, в том числе обработки сверхбольших и разрозненных источников информации уровень исследований отмечается в телекоммуникационных технологиях (передачи информации, организации сетей и распространения контента).

Быстрый рост рынков применения указанных научно-технологических достижений прогнозируется в здравоохранении, энергетике, машиностроении и на транспорте, а также в сфере персонального потребления ИКТ-продуктов и услуг. В предстоящие 5-7 лет ожидается развитие распределенных сетей телемедицинских центров, систем контроля качества и безопасности лекарственных средств и медицинских услуг. K 2025 г. получат широкое распространение медицинские микроустройства, встраиваемые в тело человека и обеспечивающие поддержание его жизненно важных функций; технологии обмена унифицированной информацией между транспортными средствами; методы повсеместного позиционирования и идентификации объектов в концепции «Интернет вещей»; перспективные платформы сбора, обобщения и представления контента и знаний.

Эволюция облачных вычислений, создание новых архитектур и принципов организации вычислений влекут за собой трансформацию ПО и внедрение инновационных изменений в бизнес-стратегии предприятий всех секторов экономики. Колоссальный рост объемов доступной информации приведет к радикальному повышению эффективности управленческих решений. 
Калин А.А. (2010) Иллюстрированные тезисы к прогнозу долгосрочного научно-технологического развития сектора информационно-коммуникационных технологий (ИКТ) России. М.: РТРС. Режим доступа: http://strategy2020.rian.ru/ load/366077780, дата обращения 06.06.2013.

Каминский И.П., Огородова Л.М., Патрушев М.В., Чулок А.А. (2013) Медицина будущего: возможности для прорыва сквозь призму технологического прогноза // Форсайт. Т. 7. № 1. С. 14-27.

Качкаева А.Г., Кирия И.В. (2012) Долгосрочные тенденции развития сектора массовых коммуникаций // Форсайт. Т. 6 . № 4. C. 6-18.

Минобрнауки России (2010) Основные результаты долгосрочного прогноза научно-технологического развития Российской Федерации на период до 2030 года (итоговый доклад). М.: Министерство образования и науки Российской Федерации. Режим доступа: http://old.mon.gov.ru/files/materials/5053/prog.ntr.pdf, дата обращения 08.07.2013.

НИУ ВШЭ (2013а) Индикаторы информационного общества: 2013. Статистический сборник. М.: НИУ ВШЭ.

НИУ ВШЭ (2013b) Долгосрочные приоритеты прикладной науки в России / Под ред. Л.М. Гохберга. М.: НИУ ВШЭ.

Саритас О. (2013) Технологии совершенствования человека: перспективы и вызовы // Форсайт. Т. 7. № 1. С. 6-13.

Соколов А.В., Чулок А.А. (2012) Долгосрочный прогноз научно-технологического развития России на период до 2030 года: ключевые особенности и первые результаты // Форсайт. Т. 6. № 1. С. 12-25.

ЦМАКП (2011) Исследование взаимосвязей важнейших параметров социально-экономического, научно-технологического и инновационного развития на период до 2030 года. М.: Центр макроэкономического анализа и краткосрочного прогнозирования.

Bartels A.H. (2009) Smart Computing Drives: The New Era of IT Growth. Cambridge, МА: Forrester Research, Inc. Режим доступа: http://www-07.ibm.com/ph/ssmeconference/pdf/smart_computing_drives_the_new_era_of_it_growth_forrester.pdf, дата обращения 08.07.2013.

BCG (2012) GeSI SMARTer 2020: The Role of ICT in Driving a Sustainable Future. Boston: Boston Consulting Group.

Cagnin C., Havas A., Saritas O. (2013) Future-oriented technology analysis: Its potential to address disruptive transformations // Technological Forecasting and Social Change. Vol. 80. P. 379-385.

Christensen C.M. (1997) The Innovator's Dilemma: When New Technologies Cause Great Firms to Fail. Boston: Harvard Business School Press.

Etzion O., Niblett P. (2010) Event Processing in Action. Cincinnati, OH: Manning Publications.

European Commission (2009) Europe's Digital Competitiveness Report. Volume 1: i2010 — Annual Information Society Report 2009 Benchmarking i2010: Trends and main achievements. COM(2009)390. Brussels: European Commission.

European Commission (2010a) Facing the future: Time for the EU to meet global challenges. Seville: IPTS, European Commission.

European Commission (2010b) Communication from the Commission to the European Parliament, the Council, the European Economic and Social Committee and the Committee of the Regions. A Digital Agenda for Europe. Report 26.8.2010 COM 245 final/2. Brussels: European Commission.

FDANEWS (2010) FDAnews Drug Daily Bulletin. Vol. 7. № 235 (December 3). Режим доступа: http://www.fdanews.com/newsletter/ article?articleId=132337\&issueId=14265, дата обращения 8.07.2013.

Financial Times (2012) FT Global 500. Режим доступа: http://www.ft.com/intl/cms/a81f853e-ca80-11e1-89f8-00144feabdc0.pdf, дата обращения 15.05.2013.

Forge S., Blackman C., Bohlin E., Cave M. (2009) A Green Knowledge Society: An ICT Policy Agenda to 2015 for Europe's Future Knowledge Society. Final Report. Brighton: SCF Associates Ltd.

Georghiou L., Cassingena Harper J., Keenan M., Miles I., Popper R. (eds.) (2008) The Handbook of Technology Foresight: Concepts and Practice. Cheltenham: Edward Elgar Publishing.

Gokhberg L., Sokolov A. (2013) Summary - Targeting STI Policy Interventions - Future Challenges for Foresight // Science, Technology and Innovation Policy for the Future: Potentials and Limits of Foresight Studies / Eds. D. Meissner, L. Gokhberg, A. Sokolov. New York, Dordrecht, London, Heidelberg: Springer. P. 289-292.

Gorissen D., Couckuyt I., Demeester D., Dhaene T. (2010) A Surrogate Modeling and Adaptive Sampling Toolbox for Computer Based Design // Journal of Machine Learning Research. Vol. 11. P. 2051-2055.

Haegeman K., Scapolo F., Ricci A., Marinelli E., Sokolov A. (2013) Quantitative and qualitative approaches in FTA: From combination to integration? // Technological Forecasting and Social Change. Vol. 80. P. 386-397.

Hendler J., Golbeck J. (2008) Metcalfe's Law, Web 2.0, and the Semantic Web // Web Semantics: Science, Services and Agents on the World Wide Web. Vol. 6. № 1. P. 14-20.

IEEE (2013) IEEE Vision for Smart Grid Communications: 2030 and Beyond. New York: IEEE.

McLaren R., Kennedy E. (2013) Data is the new currency in the location revolution - who will supply the data? Paper presented at the Annual World Bank Conference on Land and Poverty. Wasington, D.C. Режим доступа: http://www.landandpoverty.com/, дата обращения 27.07.2013.

Missikoff M., De Panfilis S. (2012) An Introduction to BIVEE. Режим доступа: http://wordpress.bivee.eu/resources/newsletter-may2012/, дата обращения 14.07.2013.

OECD (2013) New Sources of Growth: Knowledge-Based Capital Driving Investment and Productivity in the 21st Century. Paris: OECD.

Read D.S. (2012) The Rise of Semantic Databases. InformationWeek Report. December. London: UВMTесh. Режим доступа: http:// www.informationweek.com/gogreen/120512s/, дата обращения 05.08.2013.

Sokolov A. (2013) Foresight in Russia: Implications for Policy Making // Science, Technology and Innovation Policy for the Future: Potentials and Limits of Foresight Studies / Eds. D. Meissner, L. Gokhberg, A. Sokolov. New York, Dordrecht, London, Heidelberg: Springer. P. 183-198.

Schulz R. (ed.) (2012) Quality of Life Technology Handbook. London: CRC Press.

UNIDO (2005) Technology Foresight Manual. Vienna: UNIDO.

Velev D.G. (2011) Internet of Things: Analysis and Challenges // Economic Alternatives. Vol. 2. P. 99-109.

Zagaeski P. (2010) Monetizing Digital Content. GigaOm Pro Report. San Francisco, CA: Giga Omni Media, Inc. 


\title{
Long-Term Trends in the ICT Sector
}

\author{
Alexander Giglavy \\ Deputy Director for Science, Moscow Lycee no 1533 (Information Technologies). Address: Moscow Lycee no 1533 \\ (Information Technologies), 16 Lomonosovsky av., Moscow, 119296, Russian Federation. \\ E-mail: giglavy@yandex.ru
}

\begin{abstract}
Alexander Sokolov
Deputy Director, Institute for Statistical Studies and Economics of Knowledge, and Director, International Research and Educational Foresight Center, National Research University - Higher School of Economics. Address: National Research University - Higher School of Economics, 20 Myasnitskaya str., Moscow, 101000, Russian Federation. E-mail: sokolov@hse.ru
\end{abstract}

\section{Gulnara Abdrakhmanova}

Director, Centre for Statistics and Monitoring of Information Society, Institute for Statistical Studies and Economics of Knowledge, National Research University - Higher School of Economics. Address: National Research University - Higher School of Economics, 20 Myasnitskaya str., Moscow, 101000, Russian Federation. E-mail: gabdrakhmanova@hse.ru

\begin{abstract}
Alexander Chulok
Head, Division for S\&T Foresight, Institute for Statistical Studies and Economics of Knowledge, National Research University - Higher School of Economics. Address: National Research University - Higher School of Economics, 20 Myasnitskaya str., Moscow, 101000, Russian Federation. E-mail: achulok@hse.ru

\section{Vasily Burov}

Chairman of the Board, WikiVote! Address: office 2, 7 bld. 1, Fadeeva str., Moscow, 125047, Russian Federation. E-mail: burov@wikivote.ru
\end{abstract}

\begin{abstract}
nformation and communication technologies (ICT) radically transform many areas of human activity thus attracting great attention of researchers. However, the dynamics of ICT development depends on the global challenges and broader trends that define long-term S\&T priorities. What factors that will influence the future of the ICT industry? What technological solutions will determine its characteristics in the next 15-20 years? These and similar questions were considered by the HSE ISSEK specialists in co-operation with the colleagues from other research entities while investigating trends in S\&T at the global and national levels. The experts have analyzed socio-economic and S\&T challenges affecting the ICT sector, advanced R\&D fields, markets for innovative products and services, estimated the «windows of opportunities» for Russia. As a result, the strategic directions of blueprint research which ensure the basis for the creation of innovative products and new markets for the medium- and long-term (beyond 2020) perspective. Foresight results have been validated by the representatives of leading companies, research centers, universities and international organizations.
\end{abstract}

Abstract
Among the solutions expected in the period up to 2030 are the prototypes of systems implementing the new computing principles and multi-language software for extraction and formalization of knowledge, technologies dealing with «big data», new analytical tools (personal analytic systems, means of the real time data processing, mobile analytics, etc.). Markets for novel technology solutions are expected to be rapidly growing in healthcare, energy, engineering and transport, as well as in personal usage of ICT products and services.

The study allows to conclude that in the medium to long term, the ICT sector will retain a high growth dynamic and will have transformative impact on virtually all areas of human life. The life cycle of technologies, related products and services will shorten. In this context, R\&D development plays a crucial role for keeping up with competitors. Russian science has a certain potential in much of the considered areas, although one can hardly perceive Russia as gaining global leadership. A breakthrough level of research is observed, for example, in telecommunication technologies (communication, networking and content distribution).

\section{Keywords}

information and communication technologies; long-term foresight; global challenges; trends; priorities; S\&T capacities 


\section{References}

Bartels A.H. (2009) Smart Computing Drives: The New Era Of IT Growth, Cambridge, MA: Forrester Research, Inc.

BCG (2012) GeSI SMARTer 2020: The Role of ICT in Driving a Sustainable Future, Boston: Boston Consulting Group.

Cagnin C., Havas A., Saritas O. (2013) Future-oriented technology analysis: Its potential to address disruptive transformations. Technological Forecasting and Social Change, vol. 80, pp. 379-385.

Christensen C.M. (1997) The Innovator's Dilemma: When New Technologies Cause Great Firms to Fail, Boston: Harvard Business School Press.

CMASF (2011) Issledovanie vzaimosvyazei vazhneishikh parametrov sotsial'no-ekonomicheskogo, nauchno-tekhnologicheskogo $i$ innovatsionnogo razvitiya na period do 2030 goda [Studying the Links between the Most Important Parameters of Socio-Economic, Scientific, Technological and Innovation Development for the Period until 2030], Moscow: Center for Macroeconomic Analysis and Short-Term Forecasting.

Etzion O., Niblett P. (2010) Event Processing in Action, Cincinnati, OH: Manning Publications.

European Commission (2009) Europe's Digital Competitiveness Report. Volume 1: i2010 - Annual Information Society Report 2009 Benchmarking i2010: Trends and Main Achievements (COM(2009)390), Brussels: European Commision.

European Commission (2010a) Facing the future: Time for the EU to meet global challenges, Seville: IPTS, European Commission.

European Commission (2010b) Communication from the Commission to the European Parliament, the Council, The European Economic and Social Committee and the Committee of the Regions. A Digital Agenda for Europe (Report 26.8.2010 COM 245 final/2), Brussels: European Commission.

FDANEWS (2010) FDAnews Drug Daily Bulletin, vol. 7, no 235 (December 3). Available at: http://www.fdanews.com/newsletter/article? articleId $=132337$ \&issueId $=14265$, accessed 08.07.2013.

Financial Times (2012) FT Global 500 2012. Available at: http://www.ft.com/intl/cms/a81f853e-ca80-11e1-89f8-00144feabdc0.pdf, accessed 15.05.2013.

Forge S., Blackman C., Bohlin E., Cave M. (2009) A Green Knowledge Society: An ICT Policy Agenda to 2015 for Europe's Future Knowledge Society (Final Report), Brighton: SCF Associates Ltd.

Georghiou L., Cassingena Harper J., Keenan M., Miles I., Popper R. (eds.) (2008) The Handbook of Technology Foresight: Concepts and Practice, Cheltenham: Edward Elgar Publishing.

Gokhberg L., Sokolov A. (2013) Summary - Targeting STI Policy Interventions - Future Challenges for Foresight. Science, Technology and Innovation Policy for the Future: Potentials and Limits of Foresight Studies (eds. D. Meissner, L. Gokhberg, A. Sokolov), New York, Dordrecht, London: Springer, Heidelberg, pp. 289-292.

Gorissen D., Couckuyt I., Demeester D., Dhaene T. (2010) A Surrogate Modeling and Adaptive Sampling Toolbox for Computer Based Design. Journal of Machine Learning Research, vol. 11, pp. 2051-2055.

Haegeman K., Scapolo F., Ricci A., Marinelli E., Sokolov A. (2013) Quantitative and qualitative approaches in FTA: From combination to integration? Technological Forecasting and Social Change, vol. 80, pp. 386-397.

Hendler J., Golbeck J. (2008) Metcalfe's Law, Web 2.0, and the Semantic Web. Web Semantics: Science, Services and Agents on the World Wide Web, vol. 6, no 1, pp. 14-20.

HSE (2013a) Indikatory informatsionnogo obshchestva: 2013. Statisticheskii sbornik [Indicators of Information Society. Yearbook], Moscow: HSE.

HSE (2013b) Dolgosrochnye prioritety prikladnoi nauki v Rossii [Long-Term Priorities for Applied Science in Russia] (ed. L. Gokhberg), Moscow: HSE.

IEEE (2013) IEEE Vision for Smart Grid Communications: 2030 and Beyond, New York: IEEE.

Kachkaeva A., Kiriya I. (2012) Dolgosrochnye tendentsii razvitiya sektora massovykh kommunikatsii [Long-Term Trends in the Mass Communication Industry]. Foresight-Russia, vol. 6, no 4, pp. 6-18.

Kalin A. (2010) Illyustrirovannye tezisy k prognozu dolgosrochnogo nauchno-tekhnologicheskogo razvitiya sektora informatsionnokommunikatsionnykh tekhnologii (IKT) Rossii [Illustrated Abstracts to the Long-Term Forecast of S\&T Development of the ICT Sector in Russia], Moscow: RTRS. Available at: http://strategy2020.rian.ru/load/366077780, accessed 06.06.2013.

Kaminsky I., Ogorodova L., Patrushev M., Chulok A. (2013) Meditsina budushchego: vozmozhnosti dlya proryva skvoz' prizmu tekhnologicheskogo prognoza [Medicine of the Future: Opportunities for Breakthrough through the Prism of Technology Foresight]. Foresight-Russia, vol. 7, no 1, pp. 14-27.

McLaren R., Kennedy E. (2013) Data is the new currency in the location revolution - who will supply the data? Paper presented at the Annual World Bank Conference on Land and Poverty, Wasington, D.C. Available at: http://www.landandpoverty.com/, accessed 27.07.2013

MES (2010) Osnovnye rezul'taty dolgosrochnogo prognoza nauchno-tekhnologicheskogo razvitiya Rossiiskoi Federatsii na period do 2030 goda (itogovyi doklad) [The Main Results of the Russian Long-Term S\&T Foresight until 2030 (Final Report)], Moscow: Ministry of Education and Science of the Russian Federation.

Missikoff M., De Panfilis S. (2012) An Introduction to BIVEE. Available at: http://wordpress.bivee.eu/resources/newsletter-may-2012/, accessed 14.07.2013.

OECD (2013) New Sources of Growth: Knowledge-Based Capital Driving Investment and Productivity in the 21st Century (Synthesis Report). Paris: OECD.

Read D.S. (2012) The Rise of Semantic Databases. Information Week Report. December, London: UBMTech. Available at: http://www. informationweek.com/gogreen/120512s/, accessed 05.08.2013.

Saritas O. (2013) Tekhnologii sovershenstvovaniya cheloveka: perspektivy i vyzovy [Human Enhancement Technologies: Future Outlook and Challenges]. Foresight-Russia, vol. 7, no 1, pp. 6-13.

Sokolov A. (2013) Foresight in Russia: Implications for Policy Making. Science, Technology and Innovation Policy for the Future: Potentials and Limits of Foresight Studies (eds. D. Meissner, L. Gokhberg, A. Sokolov), New York, Dordrecht, London: Springer, Heidelberg, pp. 183-198.

Sokolov A., Chulok A. (2012) Dolgosrochnyi prognoz nauchno-tekhnologicheskogo razvitiya Rossii na period do 2030 goda: klyuchevye osobennosti i pervye rezul'taty [Russian Science and Technology Foresight - 2030: Key Features and First Results]. Foresight-Russia, vol. 6, no 1, pp. 12-25.

Schulz R. (ed.) (2012) Quality of Life Technology Handbook, London: CRC Press.

UNIDO (2005) Technology Foresight Manual, Vienna: UNIDO.

Velev D.G. (2011) Internet of Things: Analysis and Challenges. Economic Alternatives, vol. 2, pp. 99-109.

Zagaeski P. (2010) Monetizing Digital Content. GigaOm Pro Report, San Francisco, CA: Giga Omni Media, Inc. 


\section{ИНДИКАТОРЫ}

Использоание Интернета в организациях по видам экономической деятельности (в \% от общего числа организаций)

\begin{tabular}{|c|c|c|c|c|c|c|}
\hline & \multirow[b]{2}{*}{2005} & \multirow[b]{2}{*}{2009} & \multirow[b]{2}{*}{2010} & \multirow[b]{2}{*}{2011} & \multicolumn{2}{|r|}{2012} \\
\hline & & & & & всего & $\begin{array}{c}\text { в том числе } \\
\text { с широкополосным } \\
\text { доступом }^{\star}\end{array}$ \\
\hline Всего & 53.3 & 78.3 & 82.4 & 84.8 & 86.9 & 76.6 \\
\hline Предпринимательский сектор & 59.5 & 81.7 & 84.1 & 85.4 & 86.4 & 79.2 \\
\hline Добыча полезных ископаемых & 73.6 & 88.7 & 90.4 & 91.2 & 91.1 & 84.2 \\
\hline Обрабатывающие производства & 71.0 & 91.4 & 93.2 & 93.9 & 94.7 & 88.1 \\
\hline Производство и распределение электроэнергии, газа и воды & 53.2 & 73.2 & 77.1 & 82.0 & 84.7 & 72.8 \\
\hline Строительство & 58.1 & 89.5 & 91.5 & 91.8 & 91.7 & 84.1 \\
\hline Оптовая и розничная торговля & 55.2 & 83.7 & 87.5 & 88.6 & 90.1 & 84.6 \\
\hline Деятельность гостиниц и ресторанов & 37.7 & 72.2 & 77.7 & 80.3 & 83.8 & 73.3 \\
\hline Транспорт & 52.4 & 78.1 & 80.3 & 79.9 & 82.0 & 74.7 \\
\hline Связь & 94.0 & 93.8 & 93.8 & 94.7 & 93.9 & 90.7 \\
\hline Операции с недвижимым имуществом и предоставление услуг & 56.1 & 74.9 & 77.0 & 78.8 & 79.6 & 72.3 \\
\hline Финансовая деятельность & 83.3 & 91.9 & 93.5 & 93.9 & 95.0 & 92.1 \\
\hline Государственное управление; социальное страхование & 41.0 & 75.6 & 83.2 & 87.6 & 90.8 & 75.3 \\
\hline Высшее профессиональное образование & 91.0 & 96.2 & 97.1 & 97.6 & 98.1 & 94.2 \\
\hline Здравоохранение & 47.8 & 89.5 & 93.0 & 94.4 & 95.9 & 84.6 \\
\hline Организация отдыха и развлечений, культуры и спорта & 39.6 & 51.2 & 56.7 & 62.6 & 69.3 & 57.1 \\
\hline
\end{tabular}

Распределение организаций по максимальной скорости передачи данных через Интернет: 2012 (в \% от общего числа организаций)

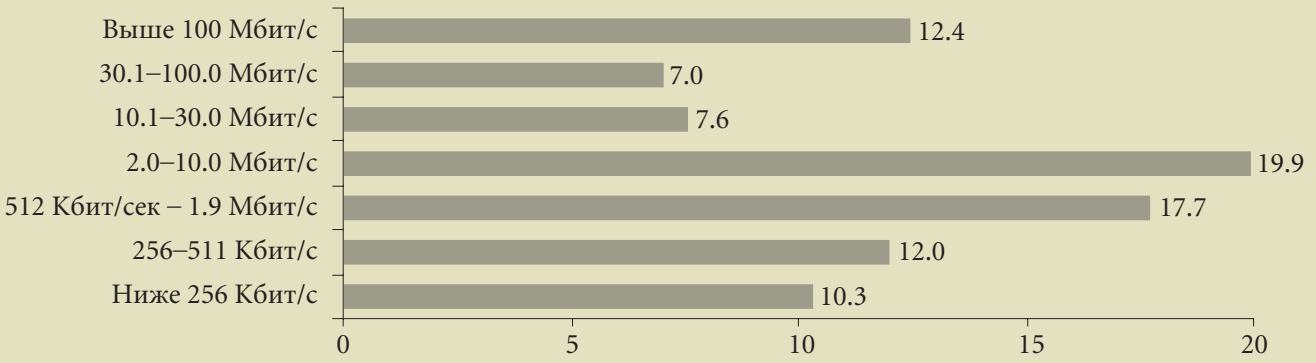

Использование широкополосного Интернета и веб-сайтов в организациях по странам: 2012 (в \% от общего числа организаций предпринимательского сектора)

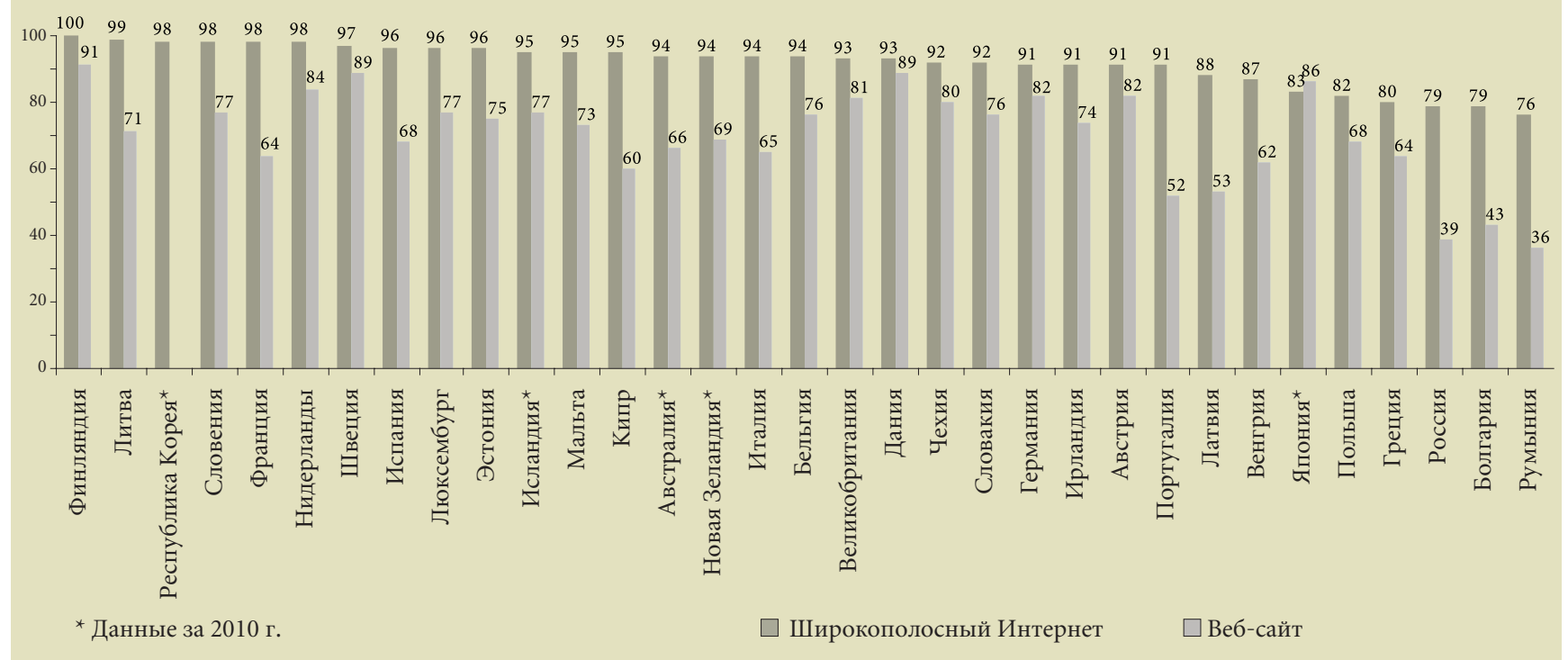

Материал подготовлен Г.Г. Ковалевой

Источники: НИУ ВШЭ (2013) Индикаторы информационного общества: 2013. Статистический сборник. М.: НИУ ВШЭ; Росстат; базы данных ОЭСР (OECD.Stat) и Евростата (Eurostat Database «Information Society Statistics»). 


\section{Эффективный контракт в науке: параметры модели'}

\section{М.А. Гершман', Т.Е. Кузнецова"}

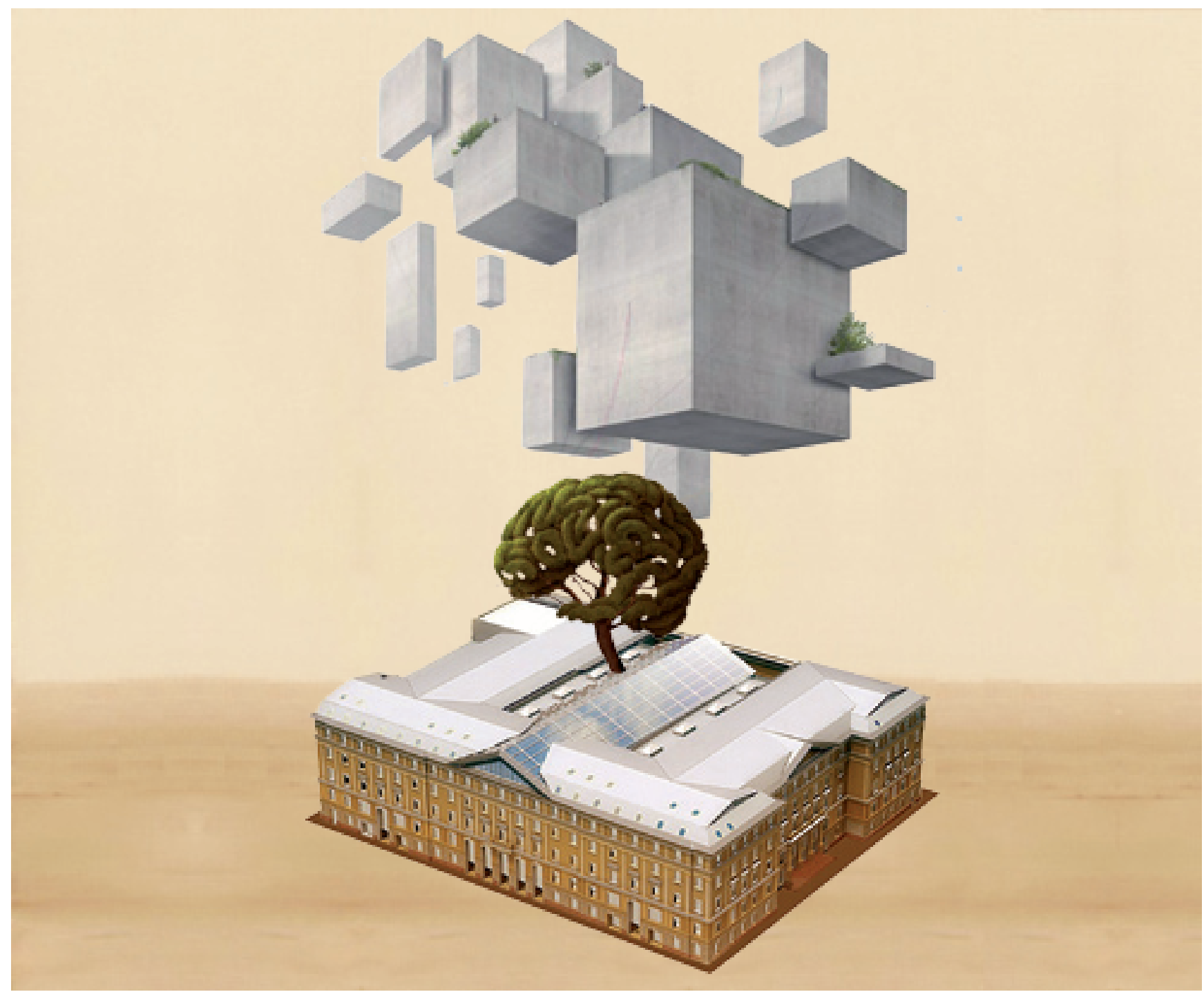

Повышение заработных плат в отечественной науке - вопрос болезненный и давно назревший. Осознавая это, в 2012 г. руководство страны наметило план совершенствования системы оплаты труда научных работников в рамках перехода к так называемому «эффективному контракту» (ЭК). Детали этой новации и практические механизмы ее реализации требуют серьезной проработки.

В статье рассмотрены результаты проведенных в НИУ ВШЭ фокус-групп, отражающие мнения представителей научного сообщества о принципах и необходимых условиях перевода научных работников на ЭК.
${ }^{\mathrm{I}}$ Гершман Михаил Анатольевич - ведущий научный сотрудник Центра научно-технической, инновационной и информационной политики. E-mail: mgershman@hse.ru

II Кузнецова Татьяна Евгеньевна - директор Центра научно-технической, инновационной и информационной политики, заместитель заведующего Лабораторией экономики инноваций. E-mail: tkuznetzova@hse.ru

Институт статистических исследований и экономики знаний (ИСИЭЗ) НИУ ВШЭ

Адрес: Национальный исследовательский университет «Высшая школа экономики», 101000, Москва, Мясницкая ул., 20

\section{Ключевые слова}

эффективный контракт; оплата труда; научный работник; исследователь; оценка результативности; научно-техническая политика

Статья подготовлена в рамках государственного контракта Минобрнауки России от 6 декабря 2012 г. № 15.521 .11 .1004 «Разработка дорожной карты перехода к “эффективному контракту” в сфере науки Российской Федерации и пакета институциональных преобразований для ее реализации». 
$\mathrm{O}$ дной из ключевых проблем развития науки в России остается недостаточная продуктив ность сектора исследований и разработок (ИиР), обусловленная множеством факторов. Особую тревогу среди них вызывает слабая заинтересованность научных работников в результатах своей дея тельности. Это связано с невысоким уровнем оплаты труда в науке (по сравнению с другими секторами экономики, а также с учеными в ведущих зарубежных странах), его низким престижем в обществе, отсутствием стимулов и условий для успешных исследований на уровне организаций, коллективов, отдельных работников.

Подобное отношение к науке, соответствующим видам деятельности и их материальной поддержке в значительной степени специфически российская проблема ${ }^{2}$. До Октябрьской революции, да и в совет ское время, образ ученого являлся в некотором смысле тождественным сложившемуся в обществе пониманию жизненного успеха, деятельности, способствующей процветанию страны. Наука рассматривалась как производительная сила экономики, перспективная область приложения усилий и способностей отдельных граждан. Именно тогда укоренились устойчивые представления о преобладании бескорыстия, энтузиазма, готовности к самопожертвованию, творческих, нематериальных ценностных ориентиров ученых. В сопоставлении с большинством других профессий они получали относительно высокое материальное вознаграждение и имели вполне достойные для того периода условия труда. Все это поддерживалось государственной пропагандой, средствами массовой информации и др.

После распада СССР в науке долгое время наблюдался системный кризис. На фоне резкого ухудшения внутренних и внешних условий снизились результативность исследовательской, экспериментальной, внедренческой деятельности, ее вклад в развитие экономики и общества. Негативным следствием таких процессов стало ухудшение глобальных позиций отечественной науки, продолжающееся до сих пор [Гохберг, Кузнеи,ова, 2011]. Уменьшился уровень зарплаты ученых; практически полностью сгладились (или стали сугубо формальными) различия между теми или иными категориями научных работников; произошел своего рода дефолт общественных представлений о значимости этой сферы для страны. Наука перестала считаться привлекательной и перспективной областью приложения труда - причем и для выпускников вузов, и для самих научных работников, и для их детей. Появилось мнение, что здесь могут работать отдельные чудаки-энтузиасты, не удачники, либо люди, которым просто некуда деться (см., например, [Гохберг и др., 2010]). Сегодня только $22 \%$ россиян считают науку главным фактором экономического роста; лишь $30 \%$ позитивно оценивают практическое внедрение ее результатов; $10 \%$ уверены, что уровень развития науки вызывает уважение у других государств (несравнимо меньше, чем богатые ресурсы и военная мощь). Большинство ставят профессию ученого на 8-е место из 16-ти возможных опций и не желали бы этого пути для своих детей [НИУ ВШЭ, 2012, с. 336, 337].

Трудности с повышением результативности ИиР испытывают многие страны, так как в отличие от других секторов здесь объективно требуется масштабное участие государства, финансовые возможности которого ограничены. В числе ключевых решений этой проблемы видятся современные, гибкие механизмы оплаты труда научных работников, учитывающие его сложность, комплексность, творческий, интеллектуальный характер ${ }^{3}$ - система $\mathrm{ЭK}^{4}$. Основная цель внедрения подобных схем - обеспечение высокой мотивации и конкурентоспособности, роста качества, продуктивности научной деятельности. Их широкое использование позволяет рассчитывать на быстрые позитивные сдвиги не только в плане оплаты труда (достижение ее эффективного уровня), но и развития науки в целом.

Целесообразность аналогичных подходов признана и в нашей стране, однако следует учесть ряд специфичных обстоятельств. Во-первых, для научнотехнической политики по-прежнему характерны недостаточная скоординированность, усеченность мер, реализуемых на разных уровнях. Вопрос о стимулировании ученых к продуктивной деятельности, внедрении эффективных механизмов оплаты труда сто ит уже давно, однако практические решения продвигаются медленно.

Во-вторых, отдельные ведомства зачастую преследуют разные цели, придерживаются собственных приоритетов ИиР и соревнуются за государственные ресурсы. Конкуренция усиливается из-за дефицита бюджета, дисбалансов в структуре экономики, масштабных финансовых и прочих обязательств государства. В итоге решения одних ведомств могут перечеркнуть планы других, сделать достижение среднесрочных и даже долгосрочных целевых показателей проблематичным, что напрямую затрагивает проблему оплаты труда. Серьезными ограничениями являются ориентировки федерального закона о бюджете, общие принципы регулирования в бюджетной сфере, заданные действующим законодательством.

B-третьих, особого упоминания заслуживает состояние нормативной правовой базы. Проблемы ее неполноты, противоречивости и фрагментарности полностью так и не решены. Как отмечалось, законодательство, регулирующее развитие науки, попрежнему находится в «арьергарде» других отраслей права, особенно бюджетного, гражданского и др. [Гохберг и др., 2011b; Кузнец,ова, 2004, 2005]. Многие вполне разумные инициативы, исходящие из «научного» блока системы федеральных органов исполнительной власти, блокируются действующими

\footnotetext{
При обсуждении вопросов занятости в сфере образования эксперты отмечали, что в нашей стране многие десятилетия она была своего рода методом идентификации личности, фетишем и объектом персонального интереса. Это стало одним из факторов усиления диспропорций в данном секторе [Кузьминов, 2011]. Примерно то же самое (хотя и не так жестко) можно сказать и о науке.

3 Особенности научного труда создают объективные сложности для описания, измерения и оценки его результатов (причем на всех уровнях - науки в целом, отдельных организаций, коллективов, работников), что влияет на возможности формирования системы критериев ЭК.

Об эффективном контракте с преподавателем см. [Кузьминов, 2011].
} 
нормами, ограничивающими реальную автономию организаций науки, правоспособность ее руководящего корпуса, в том числе в области оплаты труда, прав и обязанностей работников, вытекающих из специфики их деятельности, и др.

В 2012 г. правительство утвердило ряд документов ${ }^{5}$, предполагающих в течение ближайших нескольких лет перевести научных работников государственных и муниципальных учреждений на ЭК. Его основными параметрами являются размер заработной платы (она должна составить не менее 200\% от средней по экономике соответствующего субъекта РФ), а также принцип «оплаты по результатам», предусматривающий регулярную оценку деятельности ученого. При том что переход на ЭК уже начался, профессиональное сообщество до сих пор не получило внятных разъяснений по многим вопросам (и, похоже, пока еще само не нашло на них ответов). В частности, до сих пор не ясно, каким должно быть оптимальное соотношение между должностным окладом и стимулирующими надбавками; по каким критериям будет оцениваться работа научных сотрудников; в какой мере размер и принципы оплаты научного труда определяют его результативность и т. д.

Чтобы разобраться в этих и других вопросах, в НИУ ВШЭ была проведена серия фокус-групп с целью выявления мотивов и факторов, влияющих на эффективность научного труда, и определения возможных условий и параметров ЭК.

\section{Подход и инструментарий исследования}

Как известно, организация фокус-групп (или фокусисследований) широко используется для получения и систематизации разнообразной неколичественной информации. Особые требования к ним описаны в специальной литературе [Белановский, 1996; Ядов, 2000, и др.]. Отметим наиболее существенные для целей нашего исследования. Речь идет в первую очередь о составе фокус-групп. Очевидно, что к дискуссиям следовало привлечь представителей, по крайней мере, трех сегментов научных организаций, составляющих костяк государственной сферы, - академий наук, вузов и государственных научных центров (ГНЦ). Многие из них учреждены органами исполнительной власти (в основном федерального уровня) и ими же финансируются. Кроме того, большая часть этих структур занимается фундаментальными исследованиями, что является прямой ответственностью государства. В состав экспертов вошли представители государственных унитарных предприятий (ГУП), пока еще сохранившихся в научно-технологическом секторе. Эти предприятия имеют право на получение безвозмездных и безвозвратных перечислений из бюджетов всех уровней (на возмещение затрат или недополученных доходов в связи с производством товаров, работ, услуг согласно статье 241 Классификации операций сектора государственного управления) ${ }^{6}$. То есть они должны в какой-то мере выполнять требования, обусловленные переходом на новые механизмы оплаты труда.

Исходя из этого были сформированы целевые группы экспертов для обсуждения проблематики ЭК. В соответствии с методикой проведения фокус-групп на каждую дискуссию приглашались от восьми до двенадцати человек, чтобы обеспечить разнообразие взглядов и результативное взаимодействие экспертов.

Программы для каждого обсуждения были подготовлены заранее и включали: общую формулировку и обоснование важности цели; представление объекта и предмета исследования; некоторые ключевые гипотезы, в том числе полученные на базе результатов предварительных исследований ${ }^{7}$. В качестве единых для всех фокус-групп направлений дискуссии были выбраны:

- факторы, влияющие на текущую лояльность ученого (иерархия ценностей; система материального (включая социальный пакет и условия труда) и нематериального (в том числе продвижение по службе, профессиональное признание заслуг, обучение) стимулирования);

- аспекты, определяющие долгосрочную приверженность (престиж профессии ученого);

- эффективность организации и вознаграждения работы (специфика деятельности и должностных обязанностей, процесс ее планирования, рабочая нагрузка, методы контроля со стороны руководства, система оплаты труда и пр.);

- научная результативность (ключевые критерии, специфика применительно к различным областям науки и видам ИиР);

- институциональные факторы научной продуктивности, в том числе в контексте перехода к ЭК.

С учетом особенностей соответствующих фокусгрупп перечисленные темы дополнялись специальными вопросами, которые варьировались в зависимости от сферы деятельности экспертов.

Ниже представлены основные результаты исследования.

\section{Мотивация ученых}

Участники фокус-групп выделили два основных мотива - любопытство (интерес к изучению неиз вестного) и материальное вознаграждение 8 . Тех, кто руководствуется научным интересом, не так уж мало: это ученые «по призванию», во главу угла ставящие нематериальные соображения. Для них, в частности, решающее место в иерархии ценностей занимает признание профессиональных заслуг. Однако именно это нередко заставляет их покидать страну, чтобы самореализоваться за рубежом. Особая роль отводится

Распоряжения Правительства РФ от 30 декабря 2012 г. № 2620-р по утверждению плана мероприятий («дорожной карты») «Изменения в отраслях социальной сферы, направленные на повышение эффективности образования и науки» и от 26 ноября 2012 г. № 2190-р «Программа поэтапного совершенствования системы оплаты труда в государственных (муниципальных) учреждениях на 2012-2018 годы».

6 Подробнее см. Приказ Минфина России от 21 декабря 2012 г. № 171н «Об утверждении Указаний о порядке применения бюджетной классификации Российской Федерации на 2013 год и на плановый период 2014 и 2015 годов».

Начиная с 2006 г. в НИУ ВШЭ реализуется ряд исследовательских проектов, в том числе международных, посвященных эффективности научных коллективов, исследованию условий их работы и привлекательности научной карьеры, академическому рынку труда и др. (см., например, [Гохберг и др., 2010; Кузьминов, 2011; Сиъак, Юдкевич, 2008; Шматко, Качанов, 2010; Шматко, 2011; Altbach et al., 2012]).

8 На практике, как правило, речь идет о материальных и нематериальных факторах [Гохберг и др., 2010]. 
также творческой среде - наличию коллектива единомышленников, гибкого рабочего графика, условий для эффективного и плодотворного обмена информацией, общения с коллегами (в том числе зарубежными), адекватного руководства, налаженных кооперационных связей, позволяющих экономить время на выявлении закономерностей, найденных и изученных другими. Проверенным средством фор мирования благоприятной среды является поиск «на острие науки», что само по себе стимулирует к получению результатов высокого уровня.

«"Настоящая” наука нередко делается

в коридорах».

«Хороший начальник - это тот, который

способен выпустить статью подчиненного без

вписывания своей фамилии впереди».

(из выступлений участникољ фокус-групп)

Сказанное вовсе не означает, что таких ученых не волнует «денежный вопрос». Просто он не является абсолютной доминантой при выборе и продолжении профессиональной карьеры. Помимо собственных доходов их беспокоит финансирование научной тематики, исследовательской группы, закупки необходимого оборудования и др.

Сегодня престиж профессии ученого становится все более зависимым от материальной составляющей, что важно для привлечения и удержания в нау ке как молодых исследователей, так и специалистов с опытом. Многие из них хотят жить и трудиться в комфортных условиях, должным образом обеспе чивать свои семьи и занимать престижное положение в обществе. Здесь, безусловно, решающее значение имеет «баланс» ценностей и интересов. Участники фокус-групп полагают, что мотивы ученых во многом соответствуют известной «пирамиде потребностей» А. Маслоу [Maslow, 1954]. Однако творческий характер их работы, сложность и непредсказуемость научных результатов требуют исключительного внимания к удовлетворению потребностей, характерных для каждого уровня «пирамиды» (в особенности, ощущения значимости, правильности своего дела) высокого уровня лояльности со стороны непосредственного руководства и государства в целом.

\section{Системы оплаты труда}

В ведущих странах основное внимание уделяется в первую очередь обеспечению достойных базовых компенсаций научным работникам при соблюде нии жестких требований, связанных с результативностью при замещении академических должностей и продвижении по карьерной лестнице [Altbach et al., 2012]. В России же, по сути, продолжает действовать неэффективная и устаревшая тарифная сетка оплаты труда «бюджетников» (к которым принадлежит большинство ученых) с невысокими окладами и мини мальными различиями в зарплате разных категорий персонала. Текущий низкий уровень должностных окладов не стимулирует притока талантливой молодежи и явно недостаточен для обеспечения международной конкурентоспособности и достижения поставленных перед наукой целей.

Центральная идея, которую поддержали все участники фокус-групп, - установление достойной оплаты труда ученого. Так, исследовательские коллективы, получающие бюджетное финансирование (в формате государственного задания или грантов), должны, по общему мнению, обеспечить нормальный уровень основной зарплаты (в целях удержания кадров), а остальные средства использовать для оплаты по результатам и осуществления иных расходов. Несколько лет назад предлагалось установить минимальный базовый оклад для молодого исследователя в размере 30 тыс. руб. в месяц (с вариацией по областям знаний плюс/минус 10-25\%)9. Такой ориентир применим и сегодня, хотя и его некоторые эксперты посчитали труднодостижимым. Формально в трудовом договоре могла бы фигурировать полная сумма (например, 60 тыс. руб. в месяц), однако гарантироваться только 30 тыс. руб. - при добросовестном выполнении должностных обязанностей. Оставшуюся сумму работник получит в зависимости от достигнутых результатов. При этом нельзя сбрасывать со счетов широко распространенную «пассивную» модель поведения работников: их вполне устроит заработная плата в 30 тыс. руб. без каких-либо обязательств по повышению индивидуальной результативности. Нивелировать подобный риск можно через введение срочных контрактов на срок 3, 5 и 10 лет, практики конкурсного занятия должностей и процедур аттестации, учитывающей активность, участие в проектах по грантам и контрактам и т. п.

Для исследовательской группы (или научной организации) могут предусматриваться:

- определенное число высокооплачиваемых должностей с соответствующим уровнем заработной платы;

- несколько постоянных позиций (на условиях бессрочного договора) и «гостевых» мест.

При обсуждении этой идеи отдельные респонденты предлагали ввести квоты на высокооплачиваемые и «гостевые» места, что способствовало бы привлечению перспективных исследователей из других регионов. Дискуссионным остается вопрос о том, за кем следует закреплять право выделения и использования ставок визитеров - за ведомствами, государственными академиями наук (под академическую мобильность) либо за исследовательской группой. Неясно, как интегрировать подобные новации в действующую нормативную базу.

Эксперты полагают, что фонд оплаты труда должен непременно регулироваться и распределяться на уровне исследовательской группы (будь то неформальный коллектив исследователей, лаборатория либо межинституциональное образование и др.). В этом случае возникает сложная развилка, касающаяся объекта финансирования: выделять ли средства

\footnotetext{
Эта идея обсуждалась в ходе реализации пилотного проекта по совершенствованию системы оплаты труда научных работников и руководителей научных учреждений РАН (Постановление Правительства РФ от 7 сентября 2007 г. № 565 «О реализации второго этапа пилотного проекта совершенствования системы оплаты труда научных работников и руководителей научных учреждений и научных работников научных центров Российской академии наук»).
} 
напрямую научному коллективу либо учреждению в целом для последующей передачи исследователям (в той или иной форме). Зарубежный опыт демонстрирует жизнеспособность обеих (и многих других) моделей.

Различие в уровне заработной платы научных работников, находящихся на одинаковых должностях в различных секторах науки и регионах, большинством участников фокус-групп воспринималось как естественное явление. Действительно, качество ИиР в регионах существенно разнится ввиду сложившейся специализации, традиций, неравномерности экономического роста. Поэтому выживание и восстановление региональной науки связаны не столько с уровнем оплаты труда, сколько со всем комплексом социально-экономических и институциональных условий развития субъектов РФ. Сегодня целесообразно искать и поддерживать талантливых и результативных ученых, работающих на периферии, однако сделать это крайне сложно из-за информационного дефицита ${ }^{10}$, ограничений мобильности, административных барьеров.

«Курирующие ведомства зачастую не знают имен отечественных исследователей международного уровня».

(из выступлений участников фокус-групп)

Большинство участников фокус-групп склоняются к мнению, что ЭК следует рассматривать только применительно к исследователям. Система стимулирования и оплаты труда для вспомогательного персонала важна, но может быть эффективно организована в рамках бюджетирования исследовательских групп. Против распространения системы оплаты по результатам на весь персонал организаций (в том числе и на неосновной) свидетельствует известный негативный опыт внедрения «всеобъемлющих» систем KPI (key performance indicators - ключевые показатели эффективности деятельности) во многих российских бизнес-структурах, в частности в отдельных компаниях с государственным участием [Ряковский, 2011; Бондаренко, 2010]. В этом случае существенно вырастет и потребность в бюджетных средствах.

Стимулирующая зарплата для вспомогательного персонала (в отличие от исследователей) должна быть существенно меньше базовой: например, 40 тыс. руб. - базовая и 10-15 тыс. руб. - стимулирующая часть. В то же время следует учитывать такие объективные свойства работника, как пороги «чувствительности» и «привыкания». Первый характеризует уровень, при котором изменения в оплате являются ощутимыми для сотрудника. Общепризнано, что он не может быть меньше 25-30\%. Второй показывает, как долго люди продолжают замечать изменения в заработной плате (чувствительность к ним может со временем уменьшиться).

Как один из вариантов регулирования оплаты труда вспомогательного персонала была рассмотрена схема, получившая распространение в ряде коммерческих организаций. Это так называемая гарантированная премия (или стимулирующая надбавка первого порядка), которая выплачивается в случае если к работнику нет нареканий и допускает существование других надбавок. Впрочем, как заметили участники дискуссии, возможна и стандартная модель, когда дополнительная выплата является не гарантированной, а опциональной к базовому окладу.

Как известно, ключевым элементом системы материального стимулирования, помимо заработной платы, служит социальный пакет. При обсуждении возможных социальных гарантий и льгот в сфере науки речь шла, прежде всего, о необходимости предоставления доступного жилья молодым работникам, которые хотят создавать или уже обзавелись семьями. Такие программы пока единичны, несмотря на соответствующее решение правительства ${ }^{11}$, а условия кредитования, как правило, не привлекательны, малодоступны для потенциальных кандидатов. Некоторые университеты, создаваемые «с нуля», стараются построить на территории кампусов жилые здания для работников ${ }^{12}$. Однако пока такие примеры встречаются редко.

О введении дополнительных социальных льгот эксперты высказались достаточно категорично. Эти вопросы следует решать в рамках компетенции организации и не позиционировать как обязательный

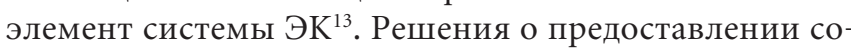
циального пакета и его составе могут служить конкурентным преимуществом конкретной научной структуры. Гибкий подход к управлению им в организации предпочтителен также ввиду региональных различий.

При объективных предпосылках ЭК позволил бы ученым зарабатывать средства, сравнимые с рыночным уровнем (например, в консалтинге), и обеспечить в обозримой перспективе приобретение жилья (пусть даже на условиях ипотеки), способствуя тем самым привлечению в науку молодежи. Вместе с тем существенное повышение уровня оплаты труда для всех исследователей без выполнения ряда необходимых условий (например, по повышению индивидуальной результативности) продуцирует определенные риски. В частности, может начаться приток в эту сферу выпускников вузов и работников других отраслей (как это происходило в СССР в первой половине и середине ХХ в. и в России в конце 1990-х гг.), что скорее не улучшит общую ситуацию, а напротив, снизит качество ИиР [Гохберг и др., 2011а]. В этом отношении ЭК должен стать не только гарантией достойной оплаты труда, но и инструментом отбора лучших.

\footnotetext{
${ }^{10}$ В последнее время на разных уровнях создаются регулярно обновляемые электронные базы данных ученых с описанием научной деятельности и достижений (например, проект «Карта российской науки» Минобрнауки России, информационная система «Истина» МГУ им. М.B. Ломоносова, база данных «Sсіеnсе Index» Российского индекса научного цитирования и др.).

${ }^{11}$ Поручение Председателя Правительства РФ от 4 августа 2011 г. «О создании специального ипотечного продукта для кредитования молодых ученых».

12 Было отмечено, что при строительстве кампуса Сибирского федерального университета заранее планировались жилые здания для персонала.

${ }^{13}$ В зарубежных странах существует практика увязки контракта с «социальным пакетом» [Altbach et al., 2008, 2012; Stevens, 2004].
} 
На практике такой отбор непременно должен увязываться с оценкой результативности научного труда, укоренившейся в государственном секторе науки за рубежом $^{14}$.

\section{Оценка результативности}

Участники дискуссии согласились с тем, что задать «идеальные» критерии оценивания на законодательном уровне невозможно ввиду существенного разнообразия научных дисциплин и отдельных учреждений. По-разному организована деятельность представителей естественных и гуманитарных наук, научных работников академий, отраслевых институтов и вузов; ученых в сфере фундаментальных исследований и в реальном секторе экономики и др. Ключевые принципы для таких групп могут быть едиными, но частные параметры систем оплаты, показатели и критерии должны различаться. По этой причине введение унифицированных оценок индивидуальной результативности в учреждениях РАН (в рамках пилотного проекта по совершенствованию системы оплаты труда научных работников и руководителей в 2006-2008 гг.) оказалось не слишком успешным, а зачастую даже и непонятным для самих научных работников $^{15}$.

«Раздают какие-то таблицы с массой критериев, все научные результаты оцениваются в 1 балл, монография приравнивается к выступлению на конференции».

(из выступлений участников фокус-групп)

Препятствием на пути выстраивания унифици рованных систем оценки результативности является многообразие видов деятельности ученого. Так, речь может идти об организационной и административной работе, когда в процессе реализации проекта ряд полномочий (по планированию и координации работ, контактам с заказчиком и др.) делегируется персоналу. В этом случае исследователь вынужден отвлекаться на иные обязанности. Очевидно, что руководители должны оценивать и поощрять таких сотрудников ${ }^{16}$. Другой пример - преподавание. По заключению участников фокус-групп, для сотрудников научных подразделений вузов подобная деятельность не является приоритетной, тогда как для преподавателя, выполняющего одновременно ИиР, в нынешних условиях основной является образовательная активность в ущерб научной. Поэтому особый интерес могут представлять функциональные модели (и должности), способные повлиять на результативность ${ }^{17}$.

Не остались без внимания вопросы, связанные со структурой занятости исследователей, непосредственно влияющей на эффективность их работы. Существенную долю времени российских ученых занимает «квазинаучная» деятельность по написанию отчетов (иногда формальных) для ведомств и иных заказчиков ИиР. Эксперты не приводили точных данных о такой активности, но подчеркивали, что часто она вынужденно доминирует в «расписании» ученого. Объясняется это просто: финансирующие ведомства требуют массу ненужной отчетности. Помимо того, для обеспечения даже среднего размера зарплаты ученые берутся и за разные консалтинговые и иные проекты, предполагающие значительный объем организационной работы.

«В науке распространено неформальное и "ненормальное" соотношение между размером субсидии и количеством страниц, составляющих отчет об ИиР».

(из выступлений участников фокус-групп)

При номинально сопоставимом количестве времени, которое тратится на исследования, на практике иностранные коллеги имеют ощутимое преимущество $^{18}$. Немного уравнять конкурентные возможности отечественных и зарубежных ученых позволило бы разумное сокращение отчетности по грантам и конкурсам целевых программ. Следовало бы узаконить право ведущих ученых на творческий отпуск после, например, 6-7 лет непрерывного стажа, как это принято в зарубежных странах (так называемый «sabbatical») ${ }^{19}$.

Возвращаясь к вопросу о показателях результативности, участники фокус-групп согласились, что наиболее точными индикаторами для фундаментальных и поисковых исследований (с учетом их тематики) являются наличие и качество публикаций. Эксперты,

\footnotetext{
${ }^{14}$ Концепция «оплаты по результатам» («performance-related pay», PRP), реализованная в 1980-1990-х гг. многими зарубежными странами в ряде социальных отраслей (образование, медицина и др.), впоследствии подверглась критике. С помощью подобных схем удается мотивировать лишь малую часть государственных служащих. Для них сильными стимулами служат само содержание работы (интерес к работе) и карьерные перспективы [Marsden, 2004; OECD, 2005, 2012].

${ }^{5}$ По крайней мере, это практически не отразилось на индикаторах результативности отечественной науки. Сами механизмы оценки допускали манипулирование показателями производительности. Вместе с тем подобные методы в отдельных случаях давали и позитивные эффекты, позволяя анализировать вклад работника в достижение целей организации.

${ }^{16}$ В зарубежных научных организациях распространены комплексные и достаточно гибкие системы оценивания результативности. К примеру, в Университете Манчестера (Великобритания) наряду с научной и образовательной активностью поощряются и административная деятельность, участие в выполнении коммерческих заказов и трансфере знаний в реальный сектор экономики. Источник: The University of Manchester - Faculty of Humanities, Academic Promotions мерческих заказов и трансфере знаний в реальный сектор экономики. Источник: The University of Manchester

${ }^{17}$ В Российском университете дружбы народов (РудН) действуют специальные положения о конкурсах («О ведущих научно-педагогических коллективах РУДН», «О научно-педагогических коллективах международного уровня в РУДН» и др.), предусматривающие стимулы и критерии оценки для различных «моделей» исследовательских коллективов и индивидуальных ученых. Подробнее см. интернет-сайт РуДН (режим доступа: http://www.rad.pfu.edu. ru/41443e43a44343c43543d44244b/polozheniya-rudn, дата обращения 17.05.2013).

18 Это время могло бы быть посвящено качественному улучшению научных статей для публикации в высокорейтинговых журналах. Отсутствие таких возможностей - один из факторов, затрудняющих достижение ряда целевых показателей учеными (например, по числу статей в рецензируемых зарубежных научных изданиях).

${ }^{19}$ Подобная практика, кстати, существовала в советской академической науке. Право научных работников на длительный отпуск предусмотрено в законопроекте «О внесении изменений в отдельные законодательные акты Российской Федерации в части совершенствования механизмов регулирования труда научных работников, а также финансовых инструментов и механизмов поддержки научной деятельности в Российской Федерации» (режим доступа: httр://минобрнауки. рф/документы/3189, дата обращения 25.08.2013).
} 
как правило, признают, что международные публикации являются ключевым индикатором результативности, но призывают использовать его осторожно, не «в лоб». Как известно, в мире все показатели, связанные с научными публикациями и цитированием, применяются в качестве некоего (пусть исключительно важного) ориентира, требующего привлечения дополнительной информации. Иначе в процессе принятия управленческих решений могут допускаться серьезные ошибки ${ }^{20}$. Для каждой агрегированной области знаний целесообразно рассматривать индивидуальные уровни публикационной активности, цитируемости и др., вводить дополнительные индикаторы продуктивности [Kahn, McGourty, 2009].

Большинство участников считают недопустимым ориентироваться при оценке результативности только на международные базы данных, где публикации размещаются исключительно на английском языке. Пока далеки от идеала и отечественные рейтинги и базы данных. При этом наметился тревожный тренд в процессе растущей популяризации указанных индикаторов, даже некоторой «зацикленности» на них органов управления появились проблемы системного характера. Так, хорошо известны отечественные и зарубежные научные издания, публикующие статьи «за деньги» без проведения должной экспертизы качества; лоббистские группы в журналах с высоким индексом цитирования и пр. ${ }^{21}$

С точки зрения оценки публикационной активности рекомендовано учитывать и публикации в отечественных журналах на русском языке. Это принципиально, например, для ученых, ориентированных на сугубо внутренние проблемы (в области языка, культуры, истории и др.). Часть подобных исследований важны только для нашей страны и объективно могут не представлять интереса для зарубежного научного сообщества, международных журналов. Не следует исключать из показателей результативности монографии (которые могут обобщать многолетний труд отдельного исследователя или коллектива), доклады на крупных зарубежных и российских конференциях. Эти сведения широко используются и за рубежом [Altbach et al., 2011; Kahn, McGourty, 2009]. В отношении вузовского сектора науки отмечалось, что недостаточно внимания уделяется оценке учебнометодической деятельности (подготовке учебников и других материалов), хотя это положение эксперты посчитали, скорее, дискуссионным.

Наконец, особый акцент был сделан на периоде, за который следует учитывать публикации. Год не может считаться релевантным в данном контексте. Желательно определять уровень публикационной активности или цитируемости, по крайней мере, за 3-5 лет.

Среди участников дискуссий были сторонники введения как «жестких» показателей результативности (например, предлагалось в обязательном порядке учитывать импакт-фактор научного журнала, в котором публикуются статьи), так и более мягких критериев. Этот факт отражает существенную неравномерность российской научной среды, сложную ситуацию в профессиональном сообществе. Справедливо и то, что эффективность научной деятельности в определенных случаях правильнее

\section{Модель эффективного контракта с профессорско-преподавательским составом и научными работниками (на примере Московского института экономики и финансов НИУ ВШЭ)}

Данная модель во многом перекликается с зарубежными механизмами оценивания деятельности ученых. Она предполагает заключение с активными «постдоками» срочного контракта на 6 лет. В течение этого периода основным критерием результативности является публикационная активность - наличие хотя бы одной статьи в авторитетном зарубежном журнале (входящем в мировые топ-25 или признанном одним из лучших международным научным сообществом). Подобная система оценки намеренно "мягче», чем в американских или израильских вузах, где требуются не менее двух публикаций в таких журналах. Менее значимыми считаются выполнение административных обязанностей, отсутствие жалоб со стороны студентов на качество преподавания и пр.

По окончании срока контракта оценка результативности и принятие решения о продлении договора сводятся преимущественно к трем вариантам:
- работник, опубликовавший статью в ведущем зарубежном журнале и выполнивший остальные обязанности на приемлемом уровне, получает право участвовать в конкурсе на «пожизненный наем» («tenure track»);

- работник, приложивший достаточно усилий, добившийся хороших результатов в отношении научных публикаций, но не сумевший разместить статью в топовых журналах, получает право на продление контракта еще на три года;

- работник, не продемонстрировавший значимые результаты, получает «утешительный» контракт на один год («grace year»), который затем окончательно расторгается.

При подобной системе существенное значение имеет процедурный вопрос: обязательная внешняя независимая экспертиза публикаций ученого и независимый по отношению к факультету состав конкурсной комиссии, принимающей решение о заключении контракта на пожизненный наем.

Источник: Московский институт экономики и финансов НИУ ВШЭ.

\footnotetext{
20 Требуется четкое понимание того, какие массивы данных используются, как рассчитываются показатели, что конкретно они означают, и т. п.

${ }^{21}$ Например, на сайте журнала Nature опубликована заметка о растущем числе научных журналов, которые ежегодно исключаются из базы данных Web of Science за недобросовестное «раздувание» индекса цитируемости [van Noorden, 2013].
} 
измерять по итогам работы единого коллектива исследователей, занятых решением целостной научной проблемы, а не как активность каждого отдельного индивида.

Для прикладных исследований в качестве наиболее объективных (с определенными оговорками) рассматривались показатели патентной активности: патенты, ноу-хау (либо число поданных заявок на получение патента).

\section{Финансирование науки}

Переход на ЭК и повышение результативности науки невозможны без улучшения ситуации с ее финансированием. В нынешних условиях финансовые механизмы настолько зарегулированы, что никак не заставляют руководителей организаций и научных коллективов, отдельных ученых работать с полной отдачей. Даже гранты работают не слишком хорошо. Есть проблемы с закупкой оборудования, материалов и др.

Финансирование фундаментальных и поисковых исследований в рамках государственного задания (базовое финансирование) явно недостаточно для достижения поставленных перед наукой целей. В отраслевых институтах выделяемые средства в расчете на одного исследователя в разы ниже, чем, например, в учреждениях Немецкого научного сообщества (Deutsche Forschungsgemeinschaft, DFG) даже без учета административного персонала.

Наша страна испытывает дефицит источников финансирования науки. По сравнению с американской системой, в которой действуют множество ведомств и фондов, финансирующих ИиР и конкурирующих за успешные проекты, не считая предпринимателей и меценатов, у нас частных инвесторов практически нет. Бизнес сдержанно инвестирует в науку, несмотря на внедрение ряда инструментов развития частногосударственного партнерства (технологические платформы, программы инновационного развития компаний с государственным участием, инновационные территориальные кластеры, совместные высокотехнологичные проекты предприятий и вузов и пр.) Сами ученые не видят стимулов для закрепления и поддержания прав на объекты интеллектуальной собственности; у научных организаций не хватает средств для пополнения премиальной части фонда оплаты труда и т. п. Эти и другие факторы тре буют не только совершенствования экономических механизмов, но и серьезного изменения законодательства, причем не столько собственно «научного», а в первую очередь - общеэкономического и обще гражданского.

Обсуждался вопрос об эффективности функционирования государственных научных фондов Российского фонда фундаментальных исследований (РФФИ) и Российского гуманитарного научного фонда (РГНФ). В 2012 г. бюджет РФФИ вырос на 2 млрд руб. — до 8 млрд руб., а РГНФ — на 500 млн руб. до 1.5 млрд руб. Это позволило увеличить средние размеры грантов, но барьеры на пути эффективного функционирования фондов так и не были преодолены. В частности, увеличение бюджета РФФИ сопровождалось требованием со стороны государства по целевому расходованию дополнительных средств на новые программы поддержки молодых ученых. В итоге, несмотря на рост финансирования, средний размер грантов по основному инициативному конкурсу (так называемому «конкурсу А») не увеличился. Как считают эксперты, правильнее было бы направлять дополнительные бюджетные средства непосредственно на увеличение среднего размера грантов, а не «распылять» их по новым конкурсам, в которых зачастую нет необходимости.

В рамках дискуссии об «идеальном» среднем размере гранта были обсуждены два тезиса. Первый заключается в том, что ученые (по крайней мере, в гуманитарных науках) привыкли к небольшим грантам. Так, по словам представителей РГНФ, проведенные фондом специальные опросы показали, что запрашиваемые заявителями средства на 80-90\% соответствовали суммам, выданным им по грантам. В связи с этим размер гранта в гуманитарной сфере предлагалось ограничить 800 тыс. руб. для коллектива из 5 исследователей, с чем вряд ли можно согласиться. С другой стороны, актуальна и потребность в «больших деньгах». По наблюдениям РФФИ, новость об увеличении среднего размера гранта (до 1 млн руб.) ведет к существенному росту числа заявок (с 8 до 10 тысяч). Поэтому в перспективе для РФФИ исследовательский грант мог бы достигать 1.5-2 млн руб. в год (без учета затрат на оборудование $)^{22}$.

Ощутимому росту размера гранта, помимо бюджетных ограничений, препятствует само его определение (в трактовке российского законодательства): работа по гранту не является для ученого основной, поэтому формально может выполняться только во внерабочее время. Поскольку увеличение его размера напрямую связано с ростом трудоемкости или объема работ, повышение финансирования после определенного предела перестанет обеспечивать наращивание производительности научного труда. Оперативное изменение концепции гранта и его правовой трактовки позволило бы создать значимую базу для роста оплаты труда исследователей в рамках модели ЭК. Так как научные фонды в контексте повышения публикационной активности имеют высокую результативность (по данным РФФИ, порядка 25\% всех российских публикаций в Web of Science за период 2008-2012 гг. подготовлены при его поддержке), стратегия наращивания бюджетов фондов будет способствовать достижению целей российской науки, зафиксированных в Указе Президента РФ от 7 мая 2012 г. № 599 (в том числе по увеличению доли публикаций российских авторов в журналах, индексируемых системой Web of Science).

Эксперты указали и на другие проблемные зоны, снижающие эффективность работы государственных научных фондов, на которые следовало бы обратить внимание: 
- Неоднозначное толкование понятия «грант», влекущее за собой ряд нерешенных вопросов (освобождение грантополучателей от уплаты подоходного налога с гранта; возможности закупки оборудования, командирования ученых за счет грантовых средств и др.).

- Недостаточность бюджета, который в совокупности для двух отечественных научных фондов не дотягивает даже до размера расходов на содержание аппарата управления Национального научного фонда США (National Science Foundation, NSF $)^{23}$.

- Ограничения по времени на расходование полученных средств в течение фискального года. Если выплаты перечисляются в конце финансового года, фонды не успевают организовать конкурсы. Возможность «переноса» средств, оставшихся после финансирования проектов, на следующий год имеется лишь «в теории». На практике этот процесс остается достаточно сложным.

- Трудности с международной экспертизой заявок. В частности, текущая организационно-правовая форма научных фондов не позволяет оплачивать работу по экспертизе заявок, выполненную нерезидентами РФ $\Phi^{24}$.

\section{Институциональный, организационный контекст}

Меры по повышению результативности науки целесообразно осуществлять одновременно с решением комплекса задач институционального и законодательного плана (зачастую с наукой напрямую и не связанных). На повестке дня остается реформирование научной сети и системы организации ИиР на всех уровня ${ }^{25}$. Повышение оплаты, которое, естественно, будет приветствоваться работниками, само по себе вряд ли улучшит ситуацию. Для государства это может стать серьезной проблемой: от «балласта» избавиться не удастся, а «кормить» его придется по повышенным ставкам. Существует опасность, что «балласт» не устранится ни при низких, ни, тем более, при высоких зарплатах, поскольку люди, относящиеся к этой категории, как правило, рассматривают занятость в научной структуре как дополнительный источник дохода, условием доступа к которому является соблюдение минимальных формальных требований.

Помимо структурных реформ, предстоит серьезно перестраивать, а возможно, даже заново выстраивать исследовательскую инфраструктуру (площади, оборудование, сервисы и др.), которая за последние годы практически полностью деградировала. «Заплатки», которые ставит на нее государство, вряд ли помогут.
По общему мнению, которое поддерживают и авторы статьи, переходить быстро и массовым образом на новую систему оплаты труда нецелесообразно и даже вредно, какие бы критерии при этом ни применялись. Сначала требуется «расчистка завалов». Тем более что тезис о завершении реформ и вознаграждении по результату ${ }^{26}$ в целом поддерживается российским научным сообществом (по крайней мере, его активной частью). Науку следует перестроить таким образом, чтобы оградить ученых от выполнения несвойственных им функций. Для этого, полагают эксперты, должны быть созданы посреднические структуры, которые сопровождают прохождение исследователем всех стадий научно-технологического цикла и в конечном счете помогают коммерциализировать идею. Это повысит продуктивность ученых, которые не будут отвлекаться от основной деятельности; позволит им получать дополнительные доходы в виде роялти; предоставит бизнесу необходимые, готовые к использованию результаты (разработки, технологии); облегчит нагрузку на бюджет.

Острый вопрос, прозвучавший в дискуссии, касался «вымирания» отечественных научных школ. Из-за демографических (уход ученых на пенсию, естественная убыль), социально-экономических (недостаточно эффективная система мотивации) и институциональных проблем многие еще сохранившиеся школы могут исчезнуть. Центральным инструментом решения этой проблемы может стать именно ЭК - при существенном повышении базовой ставки оплаты труда и эффективных стимулирующих доплатах, которые будут ощутимыми для работника. Следует также восстанавливать механизмы наставничества в научных учреждениях, пока сами наставники с их уникальным опытом еще остались и продуктивно работают.

\section{Заключение: парадигма эффективного контракта}

Резюмируя обсуждение проблематики ЭК, эксперты сошлись во мнении, что «большие деньги», обеспечивающие достойные зарплаты, науке нужны. Однако не это самое главное. Если люди не видят перспективы, ясной цели, на которую они работают (а это особенно значимо для ученых); если их деятельность не престижна и плохо оплачивается, то они не поддаются мотивированию - еще один тезис в пользу глубоких реформ в науке.

Подводя итоги, попытаемся сформулировать общую парадигму ЭК в науке, основанную на следующих принципах:

1. Соотношение между должностным окладом и стимулирующей частью может быть различным,

\footnotetext{
${ }^{23}$ Бюджет NSF составлял в 2012 г. порядка 7 млрд долл. США. Источник: The National Science Foundation (peжим доступа: http://www.nsf.gov/about/budget/, дата обращения 14.05.2013).

${ }^{24}$ В контексте ЭК система качественной экспертизы должна занять ключевое место. Как показывает опыт зарубежных стран, где фонды имеют солидную репутацию, факт получения ученым исследовательского гранта является весомым аргументом, свидетельствующим о его высокой профессиональной квалификации, повышающим шансы на получение соответствующей должности. В российском академическом сообществе активное участие в грантовых программах научных фондов повсеместно признается как фактор научного успеха; в предпринимательском секторе на это, как правило, внимания не обращают. Одним из научных фондов повсеместно признается как фактор научного успеха; в предпринимательском секторе на это, как правило, внимания не об
сдерживающих факторов является слабость демонстрационной, просветительской и даже рекламно-пропагандистской политики фондов.

${ }^{25}$ По оценкам участников фокус-групп, в некоторых научных направлениях до 90\% исследовательских коллективов по разным причинам работают неэффективно, причем многие из этого состояния никогда не выйдут. Так, в области биомедицины продуктивными считаются 450 из почти 4 тысяч лабораторий. Проблема «пустых коридоров» в науке сохраняется, хотя ее решение давно очевидно.

${ }^{26}$ См. материалы заседания Совета по науке и образованию при Президенте РФ 29 ноября 2012 г. (режим доступа: http://www.kremlin.ru/news/16726, дата обращения 10.03.2013).
} 
однако главное - обеспечить достойную гарантированную зарплату исследователей. Только так можно привлечь в науку и талантливую молодежь, и опытных специалистов. Важное условие - регулирование фонда оплаты труда на уровне исследовательской группы.

2. Стимулирование результативности в науке необходимо. Этому могут способствовать такие механизмы, как срочные контракты, процедуры аттестации и конкурсного занятия научных должностей. Ключевыми критериями производительности для фундаментальных и поисковых исследований являются наличие и качество публикаций, а для прикладных - патенты (или заявки на их получение) и ноу-хау. Ввиду многочисленных особенностей и тонкостей измерения данные индикаторы нельзя использовать впрямую, «в лоб»: они, как минимум, требуют учета специфики соответствующей научной области и конкретной организации. В противном случае принятые на их основе решения могут оказаться ошибочными.
3. Научные работники должны достойно зарабатывать. Но построить работающую систему ЭК в науке без проведения глубоких преобразований вряд ли удастся. Соответствующие изменения давно назрели и касаются реструктуризации сектора ИиР (отбора лучших), оптимизации системы финансирования (привлечения дополнительных источников, совершенствования работы научных фондов и др.), модернизации материально-технической базы, принятия целевых мер для сохранения научных школ и привлечения молодежи.

Отмеченные идеи не новы: экспертное сообщество, профильные ведомства и правительство не раз о них заявляли. Однако действия, которые осуществляются для их «претворения в жизнь», пока не приводят к сколько-нибудь значимым результатам. Надеемся, что усилия по достойному поощрению труда ученых, повышению продуктивности и престижа российской науки в течение ближайших лет оправдают себя, а предусмотренные на эти цели средства справедливо найдут своих получателей.

Белановский С.А. (1996) Метод фокус-групп. М.: Издательство Магистр.

Бондаренко Т. (2010) «Работа над ошибками», или как разработать эффективную систему КРІ // Менеджмент сегодня. № 4. C. $236-241$.

Гохберг Л.М., Китова Г.А., Кузнецова Т.Е., Шувалова О.Р. (2010) Российские ученые: штрихи к социологическому портрету. М.: НИУ ВШЭ.

Гохберг Л.М. , Городникова Н.В., Китова Г.А., Кузнецова И.А., Кузнецова Т.Е., Соколов А.В. (2011а) Отечественная наука и научная политика в конце XX века: тенденции и особенности развития (1985-1990) / Под общ. ред. Л.М. Гохберга. М.: Фонд современной истории, Издательство Московского университета.

Гохберг Л.М., Заиченко С.А., Китова Г.А., Кузнецова Т.Е. (2011b) Научная политика: глобальный контекст и российская практика. М.: НИУ ВШЭ.

Гохберг Л.М., Кузнецова Т.Е. (2011) Стратегия-2020: новые контуры инновационной политики // Форсайт. Т. 5. № 4. С. $40-46$.

Кузнецова Т.Е. (2004) Актуальные проблемы совершенствования законодательства о науке // Законодательство о науке.

Современное состояние и перспективы развития. М.: Норма. С. 78-103.

Кузнецова Т.Е. (2005) Правовой фактор научно-технического развития России: область неопределенности // Науковедение и новые тенденции в развитии российской науки. М.: Логос. С. 122-139.

Кузьминов Я.И. (2011) Академическое сообщество и академические контракты: вызовы и ответы последнего времени //

Контракты в академическом мире / Под ред. М. М. Юдкевич. М.: НИУ ВШЭ. С. 13-30.

НИУ ВШЭ (2013) Индикаторы науки: 2013. Статистический сборник. М.: НИУ ВШЭ.

Ряковский С. (2011) KPI в российских компаниях: трудности перевода // Справочник по управлению персоналом. № 5. М.: Издательский дом «МЦФЭР». С. 10-11.

Сивак Е.В., Юдкевич М.М. (2008) «Закрытая» академическая среда и локальные академические конвенции // Форсайт. Т. 2 . № 4. C. 32-44.

Шматко Н.А. (2011) Научный капитал как драйвер мобильности ученых // Форсайт. Т. 5. № 3. С. 18-32.

Шматко Н.А., Качанов Ю.Л. (2010) Эффективность управления научно-исследовательским коллективом. М.: Университетская книга.

Ядов В.А. (2000) Стратегия социологического исследования: описание, объяснение, понимание социальной реальности.

М.: Добросвет.

Altbatch P., Pacheco I., Rumbley L. (2008) International Comparison of Academic Salaries: An exploratory study. Chestnut Hill, MA: Boston College Center for International Higher Education.

Altbach P., Reisberg L., Yudkevich M., Androushchak G., Pacheco I. (eds.) (2012) Paying the Professoriate. A Global Comparison of Compensation and Contracts. New York: Routledge.

Kahn C., McGourty S. (2009) Performance Management at R\&D Organizations. Practices and Metrics from Case Examples. Bedford, MA: The MITRE Corporation.

Marsden D. (2004) The Role of Performance Related Pay in Renegotiating the 'Effort Bargain': The Case of the British Public Service // Industrial and Labor Relations Review. Vol. 57. № 3. P. 350-370.

Maslow A. (1954) Motivation and Personality. New York: Harper \& Row.

OECD (2005) Paying for Performance: Policies for Government Employees. Policy Brief. Paris: OECD.

OECD (2012) Does performance-based pay improve teaching? Paris: OECD.

Stevens P. (2004) Academic salaries in the UK and US // National Institute Economic Review. Vol. 190. № 1. P. 104-113.

van Noorden R. (2013) New record: 66 journals banned for boosting impact factor with self-citations. Режим доступа: http://blogs.nature. com/news/2013/06/new-record-66-journals-banned-for-boosting-impact-factor-with-self-citations.html, дата обращения 15.07.2013). 


\title{
Efficient Contracting in the R\&D Sector: Key Parameters
}

\author{
Mikhail Gershman \\ Leading Research Fellow, Centre for S\&T, Innovation and Information Policy. E-mail: mgershman@hse.ru
}

Tatiana Kuznetsova

Director, Centre for S\&T, Innovation and Information Policy, and Deputy Head, Laboratory for Economics of Innovation.

E-mail: tkuznetzova@hse.ru

Institute for Statistical Studies and Economics of Knowledge, National Research University - Higher School of Economics Address: National Research University - Higher School of Economics, 20, Myasnitskaya str., Moscow, 101000, Russian Federation

\begin{abstract}
I n 2012, the Russian government drew up a plan for improving the system of research remuneration by implementing the so-called «efficient contract» model in public R\&D organizations. The details of this government initiative, however, still remain unclear, as do specific implementation arrangements.

The paper provides the results of focus groups, held by the Higher School of Economics, in order to identify potential parameters of efficient contract modeling in the R\&D sector. The discussions involved representatives from the State Academies of Sciences, universities and government research centers. Among issues raised were the organization of labor and remuneration system in the R\&D sector, productivity of scientific activities, institutional conditions for a transition to "efficient contracts», and factors affecting the loyalty of researchers.

Major conclusions presented in the paper include recommendations for salaries and for the research remuneration system for R\&D personnel. In the authors'

view, one of the key parameters of an efficient research contract should be a «fair» minimum salary guaranteed by the government.

Another recommendations in reference to $R \& D$ evaluation is that efficient contracts should guarantee not only fair rewards but also competitive selection in order to prevent an excessive inflow of the workforce from other sectors of the economy.

Finally, the paper discusses problems of funding and the institutional development of the R\&D sector. In the authors' view, it will hardly be possible to build a high-performing system of efficient contracts without implementing profound reforms restructuring the $R \& D$ sector («selection of the best»), improving the funding system (finding additional sources of investment, streamlining the operation of public science foundations), modernizing the physical infrastructure, and arranging for the conservation of Russian scientific schools and attracting young talent.
\end{abstract}

\section{Keywords}

efficient contract; remuneration system; researcher; R\&D evaluation; pay-for-performance; S\&T policy

\section{References}

Altbatch P., Pacheco I., Rumbley L. (2008) International Comparison of Academic Salaries: An exploratory study, Chestnut Hill, MA: Boston College Center for International Higher Education.

Altbach P., Reisberg L., Yudkevich M., Androushchak G., Pacheco I. (eds.) (2012) Paying the Professoriate. A Global Comparison of Compensation and Contracts, New York: Routledge.

Belanovskii S. (1996) Metod fokus-grupp [Method of Focus Groups], Moscow: Izdatel'stvo Magistr.

Bondarenko T. (2010) «Rabota nad oshibkami», ili kak razrabotat' effektivnuyu sistemu KPI [«Correction of errors», or how to develop an effective system of KPI]. Menedzhment segodnya, no 4, pp. 236-241.

Gokhberg L., Kitova G., Kuznetsova T., Shuvalova O. (2010) Rossiiskie uchenye: shtrikhi k sotsiologicheskomu portretu [The Russian Scientists: Sketches to a Sociological Portrait], Moscow: HSE.

Gokhberg L., Gorodnikova N., Kitova G., Kuznetsova I., Kuznetsova T., Sokolov A. (2011a) Otechestvennaya nauka i nauchnaya politika v kontse XX veka: tendentsii i osobennosti razvitiya (1985-1990) [Domestic science and science policy in the late twentieth century: Trends and patterns of development (1985-1999)] (ed. L. Gokhberg). Moscow: Modern History Fund, Moscow State University.

Gokhberg L., Kuznetsova T. (2011) Strategiya-2020: novye kontury innovatsionnoi politiki [Strategy 2020: New Outlines of Innovation Policy]. ForesightRussia, vol. 5, no 4, pp. 40-46.

Gokhberg L., Zaichenko S., Kitova G., Kuznetsova T. (2011b) Nauchnaya politika: global'nyi kontekst i rossiiskaya praktika [Science Policy: A Global Context and Russian Practice], Moscow: HSE.

HSE (2013) Indikatory nauki: 2013. Statisticheskii sbornik [Science and Technology Indicators in the Russian Federation. Data Book], Moscow: HSE.

Kahn C., McGourty S. (2009) Performance Management at R\&D Organizations. Practices and Metrics from Case Examples, Bedford, MA: The MITRE Corporation.

Kouzminov Y. (2011) Akademicheskoe soobshchestvo i akademicheskie kontrakty: vyzovy i otvety poslednego vremeni [The academic community and academic contracts: Challenges and responses of the last time]. Kontrakty v akademicheskom mire [Contracts in the Academic World] (ed. M. Yudkevich), Moscow: HSE, pp. 13-30.

Kuznetsova T. (2004) Aktual'nye problemy sovershenstvovaniya zakonodatel'stva o nauke [Facing the challenges of improving the legislation on science]. Zakonodatel'stvo o nauke. Sovremennoe sostoyanie i perspektivy razvitiya [Science legislation. State-of-art and prospects of development], Moscow: Norma, pp. 78-103.

Kuznetsova T. (2005) Pravovoi faktor nauchno-tekhnicheskogo razvitiya Rossii: Oblast' neopredelennosti [The legal factor of S\&T development of Russia: An uncertainty]. Naukovedenie i novye tendentsii v razvitii rossiiskoi nauki [Sociology of science and new trends in the development of Russian science], Moscow: Logos, pp. 122-139.

Marsden D. (2004) The Role of Performance Related Pay in Renegotiating the «Effort Bargain»: The Case of the British Public Service. Industrial and Labor Relations Review, vol. 57, no 3, pp. 350-370.

Maslow A. (1954) Motivation and Personality, New York: Harper \& Row.

OECD (2005) Paying for Performance: Policies for Government Employees. Policy Brief, Paris: OECD.

OECD (2012) Does performance-based pay improve teaching?, Paris: OECD.

Ryakovskii S. (2011) KPI v rossiiskikh kompaniyakh: trudnosti perevoda [KPI in Russian companies: The difficulties of translation]. Spravochnik po upravleniyu personalom [Handbook of Personnel Management], no 5, Moscow: MTsFER, pp. 10-11.

Shmatko N. (2011) Nauchnyi kapital kak draiver mobil'nosti uchenykh [Scientific Capital as a Driver of Researchers' Social Mobility]. Foresight-Russia, vol. 5, no 3, pp. 18-32.

Shmatko N., Kachanov Yu. (2010) Effektivnost' upravleniya nauchno-issledovatel'skim kollektivom [Efficiency in Management of Research Team], Moscow: Universitetskaya kniga.

Sivak E., Yudkevich M. (2008) «Zakrytaya» akademicheskaya sreda i lokal’nye akademicheskie konventsii [«Closed» Academic Environment and Local Academic Conventions]. Foresight-Russia, vol. 2, no 4, pp. 32-44.

Stevens P. (2004) Academic salaries in the UK and US. National Institute Economic Review, vol. 190, no 1, pp. 104-113.

van Noorden R. (2013) New record: 66 journals banned for boosting impact factor with self-citations. Available at: http://blogs.nature.com/news/2013/06/ new-record-66-journals-banned-for-boosting-impact-factor-with-self-citations.html, accessed 15.07.2013.

Yadov V. (2000) Strategiya sotsiologicheskogo issledovaniya: opisanie, ob"yasnenie, ponimanie sotsial'noi real'nosti [The strategy of sociological research: Description, explanation, understanding of social reality], Moscow: Dobrosvet. 


\section{НОВЫЕ ИЗДАНИЯ}

\section{Science, Technology and Innovation Policy for the Future. Potentials and Limits of Foresight Studies}

Ed. by D. Meissner, L. Gokhberg, A. Sokolov. Heidelberg, New York, Dordrecht, London: Springer, 2013. 292 p. ISBN 978-3642318269

В монографии рассмотрен широкий круг вопросов, связанных с методологией и практическими инструментами разработки научно-технологических прогнозов, оценкой их роли в формировании научно-технической и инновационной политики. Обсуждаются особенности применения методов Форсайта на международном, национальном и отраслевом уровнях. Специальный раздел посвящен анализу динамики развития системы науки и инноваций, проблем, с ко торыми ей приходится сталкиваться в условиях нарастания вызовов со стороны экономики и общества, поиску адекватных механизмов политики и способов измерения их эффективности. Лица, принимающие решения в сфере государственного и корпоративного управления, аналитики, исследователи найдут рекомендации по эффективному использованию результатов научно-технологических прогнозов и описание актуальной повестки Форсайт-исследований

\section{Handbook of Innovation Indicators and Measurement}

Ed. by Fred Gault. Cheltenham: Edward Elgar Publishing, 2013. 512 p. ISBN 978-0-85793-364-5

Издание, подготовленное с участием ведущих мировых экспертов, в том числе ряда сотруд ников ИСИЭЗ НИУ ВШЭ, характеризует современные подходы к оценке инновационной деятельности, включая терминологию, индикаторы, инструментарий статистического измерения, формы представления результатов и возможности их практического использования при разработке стратегий инновационного развития. Особый акцент сделан на перспективных направлениях измерения инноваций — индикаторах возникающих и поддерживающих тех нологий, социальных инноваций, инноваций в сфере услуг и др., а также роли индикаторов в Форсайт-исследованиях. Книга адресована сотрудникам международных организаций, орга нов управления различного уровня, менеджерам компаний, а также исследователям, занимаю щимся проблемами инновационного развития.

\section{Долгосрочный прогноз научно-технологического развития Российской Федерации на период до 2030 года}

Готовится к печати

В публикации представлены результаты Долгосрочного прогноза научно-технологического развития России на период до 2030 года, подготовленного при участии более 2000 ведущих российских и международных экспертов. Рассматриваются ключевые научно-технологические и социально-экономические тренды, формируемые ими глобальные и национальные вызовы, зарождающиеся рынки, перспективные группы инновационных продуктов и технологии, необходимые для их производства. В фокусе прогноза - приоритетные области для формирования научных заделов, обеспечивающих конкурентоспособность российских производителей. Оценивается уровень исследований российских ученых в соотношении с мировыми лидерами. Приводятся рекомендации по повышению эффективности сферы науки и технологий, стимулированию инновационной активности и развитию высокотехнологичных секторов. Издание будет полезно сотрудникам органов государственного управления, бизнесменам, ученым, студентам и широкому кругу читателей, интересующихся будущим науки и технологий.

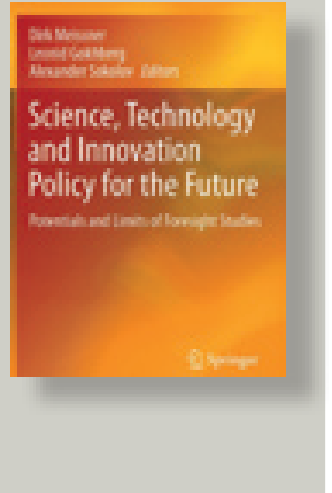

\section{Долгосрочные приоритеты прикладной науки в России}

Под ред. Л.М. Гохберга. М.: НИУ ВШЭ, 2013. 120 с. ISBN 978-5-9904002-2-1

Издание подготовлено в рамках разработки Долгосрочного прогноза научно-технологического развития России на период до 2030 года. В нем представлены приоритеты долгосрочного раз вития прикладной науки как потенциальная основа технологической модернизации секторов российской экономики. Рассмотрены семь приоритетных направлений: «Информационнокоммуникационные технологии», «Биотехнологии», «Медицина и здравоохранение», «Новые материалы и нанотехнологии», «Рациональное природопользование», «Транспортные и космические системы», «Энергоэффективность и энергосбережение». Для каждого из них выделены ключевые тематические области, проанализированы перспективные инновационные продукты и задачи прикладной науки, оценено состояние отечественных исследований на фоне мировых трендов. Целевая аудитория - органы государственного управления, компании, научные организации, вузы, технологические платформы, инновационные территориальные кластеры.
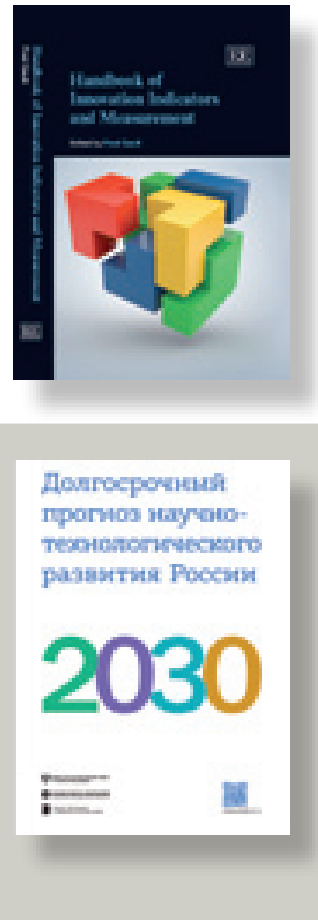

\section{Пилотные инновационные территориальные кластеры в Российской Федерации}

Под ред. Л.М. Гохберга, А.Е. Шадрина. М.: НИУ ВШЭ, 2013. 108 с. ISBN 978-5-9904002-4-5

Аналитический доклад посвящен итогам первого этапа программы поддержки кластеров, стартовавшей в России в 2012 г. Обобщен зарубежный опыт реализации аналогичных национальных программ, изложены критерии и порядок отбора пилотных инновационных территориальных кластеров, а также предполагаемые меры по их дальнейшему развитию. Основное внимание уделено сравнительному анализу производственного и инновационного потенциала 25 пилотных кластеров, источникам и направлениям их финансирования. Публикация предназначена для управленцев, исследователей, преподавателей, аспирантов, студентов и всех интересующихся проблемами инновационной политики и регионального развития.
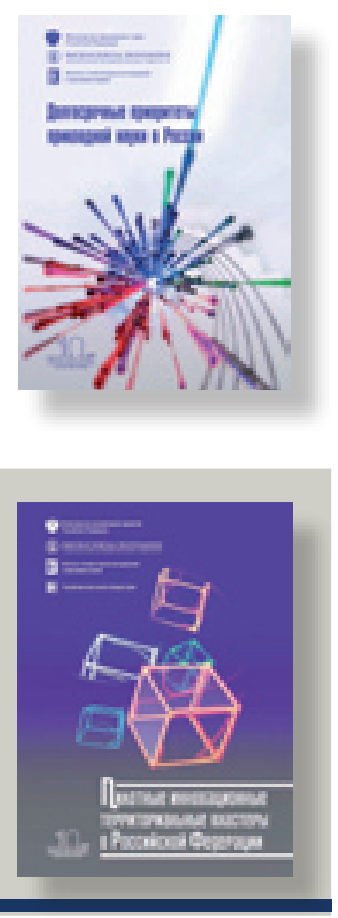


\section{Академическая профессия в сравнительной перспективе: 1992-2012'}

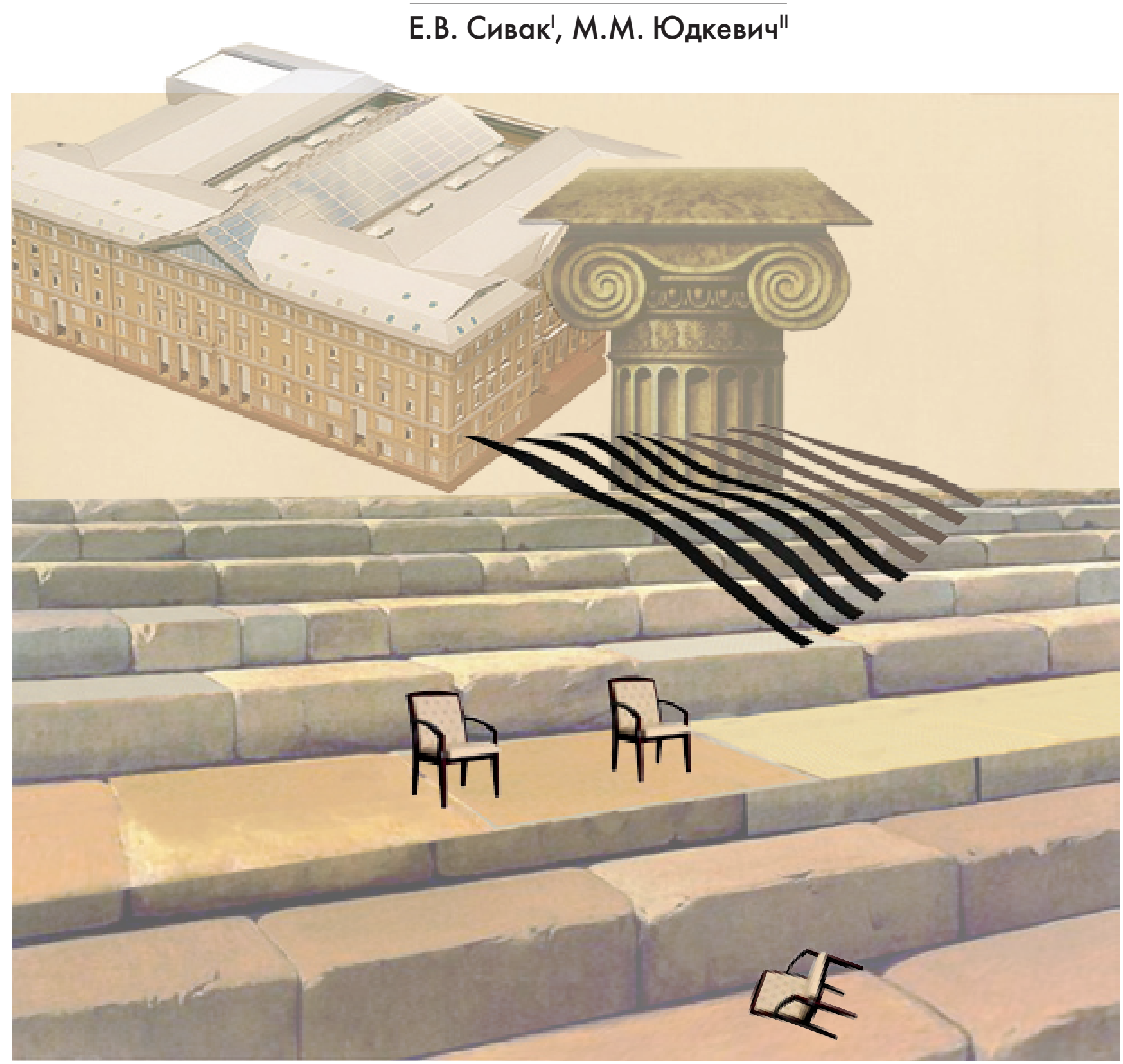

Отечественная система высшего образования претерпела коренные перемены. Изменилось и восприятие ее миссии. Если раньше стояла задача подготовить студентов к успешной профессиональной карьере, то теперь приоритетом видится усиление конкурентного потенциала страны на международном уровне. Однако вряд ли сегодня можно говорить о готовности вузов конкурировать в международном академическом сообществе.

К такому выводу пришли авторы статьи, сопоставив результаты двух международных опросов университетских преподавателей, проведенных с разницей в 20 лет.
I Сивак Елизавета Викторовна - младший научный сотрудник. E-mail: elizaveta.sivak@gmail.com

${ }^{\text {II }}$ Юдкевич Мария Марковна - директор.

E-mail: yudkevich@hse.ru

Институт институциональных исследований (ИНИИ) НИУ ВШЭ

Адрес: Национальный исследовательский университет «Высшая школа экономики», 101000, Москва,

Мясницкая ул., 20

\section{Ключевые слова}

академическая профессия; высшее образование; академические контракты; университетское управление; исследовательские университеты; преподавание и исследования

Авторы выражают благодарность Ф. Альтбаху, М. Финкельштейну и Дж. Форесту за помощь в поиске и доступе к данным исследования Центра Карнеги, а также всем участникам семинара «Академическая профессия в международном контексте», прошедшем в НИУ ВШЭ в июне 2013 г., за ценные замечания и комментарии. 
$\mathrm{H}$ ачиная с 1990-х гг. на российском рынке высшего образования происходят радикальные институциональные изменения, затронувшие академическую профессию. С одной стороны, динамично развивается частный сегмент, с другой - наблюдаются системное недофинансирование (отразившееся на зарплатах преподавателей, условиях труда и доступе к современным образовательным и исследовательским технологиям) и, как следствие, отток кадров из академического сектора. Этот период характеризовался высокой неопределенностью и турбулентностью академической культуры, совместной работой представителей разных поколений с неодинаковыми ценностными ориентирами и ожиданиями.

В течение нескольких лет в нашей стране реализуются масштабные программы государственной поддержки ведущих вузов, направленные на усиление глобальной конкурентоспособности отечественной научно-образовательной сферы и повышение качества обучения до мирового уровня Однако примеры отдельных элитных заведений в этом отношении не являются показателем перспектив академической системы в целом, ведь лидеры не смогут полноценно развиваться в отрыве от остальной ее части. Анализ расширенного контекста позволяет получить адекватное представление о состоянии академической профессии.

В России до сих пор отсутствует рынок, обеспечивающий нормальное развитие профессии и усиление ее конкурентоспособности. При оценке перспектив следует опираться как на количественные показатели (число публикаций, объем средств, выделяемых на научные исследования, и пр.) и их динамику, так и на структурные особенности организационной деятельности, состояние академической профессии (включая самооценку работников, их культурные характеристики и т. п.).

\section{Исходные данные и методология}

В основу статьи положены результаты двух исследований. Первое из них, «Академическая профессия в международной перспективе» (International Academic Profession, IAP), было организовано в 1992 г. Центром
Карнеги и позволило собрать данные о состоянии академической профессии в 14 странах, включая Россию [Altbach, 1996]. Оно стало пилотным международным исследованием, нацеленным на осмысление академической профессии в сравнительной перспективе. Двадцатью годами позднее ИНИИ НИУ ВШЭ провел оценку российского университетского сектора по международной методологии «Changing Academic Profession» (CAP). $\mathrm{Pa}$ нее данные с использованием упомянутой методологии были получены по 19 странам Европы, США, Латинской Америки и Азии [Teichler et al., 2013]. Участники этого проекта, многие из которых ранее были задействованы в IAP, не только изучили большее количество стран, но и проанализировали базовые понятия, характеризующие академическую профессию, что позволило повысить уровень сопоставимости данных и осуществить их качественную оценку. В итоге проект САР стал наиболее значимым информационным ресурсом, раскрывающим особенности и состояние дел в академической профессии в целом ряде стран, позволяя рассматривать их как по отдельности, так и в сопоставлении. В 1992 г. выборка российского опроса была ограничена только вузами Москвы и Санкт-Петербурга, поэтому из всей выборки обследования, которое проводилось в 9 регионах, в целях обеспечения сопоставимости данных была сформирована подвыборка из вузов двух крупнейших российских городов.

Таким образом, в 1992 г. были опрошены свыше 400 преподавателей, а в 2012 г. в Москве и СанктПетербурге - более 700 (табл. 1). В последнем случае образовательные учреждения отбирались произвольно из двух категорий: обладатели статуса федерального либо национального исследовательского университета (НИУ) и прочие, с тем чтобы носители особого статуса, означающего поддержку научной деятельности, большее финансирование и т. д., попали в выборку и могли сравниваться с остальными участниками.

В результате в 2012 г. в подвыборке из 11 московских и санкт-петербургских вузов оказались пять национальных исследовательских университетов непропорционально высокая доля обладателей особого статуса. На два мегаполиса приходится около четвер-

\section{Табл. 1. Распределение респондентов по дисциплинам (в соответствии с профилем} кафедры, \% от общей численности опрошенных)

\begin{tabular}{|l|c|c|}
\hline & 1992 & 2012 \\
\hline Педагогика и образование & 0.5 & 6.6 \\
\hline Гуманитарные науки, культура и искусство & 10 & 7.3 \\
\hline Социальные и психологические науки (кроме экономики, управления) & 5 & 4.7 \\
\hline Экономика и управление (в том числе бизнесом) & 11.2 & 1.1 \\
\hline Право & 1.6 & 5.5 \\
\hline Биологические, биомедицинские и биоинженерные науки & 21.5 & 2.1 \\
\hline Физические, химические и математические науки, науки о Земле & 40.9 & 37.9 \\
\hline Инженерное дело и технические специальности, строительство и архитектура & 0.2 & 0.1 \\
\hline Сельское и рыбное хозяйство & 0 & 0.7 \\
\hline Транспортные услуги, услуги защиты безопасности & 0.9 & 0.7 \\
\hline Другие специальности & 7.1 & 8 \\
\hline Затрудняюсь ответить/нет ответа & 100 (438 чел.) & 100 (708 чел.) \\
\hline Общая численность & 0.7 \\
\hline
\end{tabular}

Источник: ИНИИ НИУ ВШЭ. 
ти всех самостоятельных отделений государственных вузов (17 и 7\% соответственно). При этом в Москве обучаются 400 тыс. очных студентов (что составляет $16 \%$ от всех «очников»), в Санкт-Петербурге - почти 200 тыс. (8\%). Сюда входит основная часть учебных заведений, которые в 2006-2008 гг. были реципиентами бюджетных средств в рамках мер поддержки инновационных образовательных программ, и тех, которые в 2008-2009 гг. получили статус национальных исследовательских университетов.

Рассмотрим далее результаты сравнения академической среды в ряде дисциплин по таким показателям, как:

- приоритеты в области науки и преподавания;

- аргументы в пользу ухода либо развития академической карьеры;

- модели принятия решений в университетах и степень влияния на них со стороны индивидуальных преподавателей.

\section{Динамика академической профессии}

\section{Приоритеты в области науки и преподавания}

Индивидуальные предпочтения в пользу преподавания либо исследований влияют не только на бюджет времени преподавателя, но и на результаты его деятельности в соответствующих направлениях. Так, сегодня значимо $^{2}$ большее число преподавателей считают приоритетом исследовательскую активность (табл. 2).

Несмотря на наметившийся в последние годы сдвиг ориентации от преподавания в сторону науки, в России соответствующий показатель «исследовательских» предпочтений по-прежнему минимален по сравнению с другими странами - участницами проекта САР (рис. 1), даже при том что в выборке непропорционально много НИУ [Teichler et al., 2013].

Как и 20 лет назад, значительно меньшая доля мужчин отдает предпочтение преподаванию. Причем зависимость от пола стала не такой заметной, как в начале 1990-х гг., когда мужчины выбирали науку вдвое чаще женщин.
Табл. 2. Приоритет: преподавание или исследования (\% от общей численности ответивших)

Вопрос: Что касается Ваших собственных предпочтений, Вас интересует в первую очередь преподавание или научная работа? (ориентация на преподавание - в первую очередь преподавание) скорее преподавание; ориентация на исследования - в первую очередь научная работа / скорее научная работа).

\begin{tabular}{|l|c|c|}
\hline & 1992 & 2012 \\
\hline $\begin{array}{l}\text { В первую очередь } \\
\text { преподавание }\end{array}$ & 18 & 17 \\
\hline $\begin{array}{l}\text { И то, и другое, но больше } \\
\text { склоняюсь к преподаванию }\end{array}$ & 50 & 43 \\
\hline $\begin{array}{l}\text { И то, и другое, но больше } \\
\text { склоняюсь к научной работе }\end{array}$ & 29 & 36 \\
\hline $\begin{array}{l}\text { В первую очередь научная } \\
\text { работа }\end{array}$ & 3 & 4 \\
\hline Общая численность & 100 (413 чел.) & 100 (669 чел.) \\
\hline
\end{tabular}

Источник: ИНИИ НИу ВШЭ.

\section{Работа как источник стресса}

Существенно (и статистически значимо) меньшая, чем двадцатью годами ранее, часть опрошенных считают, что работа для них «является источником постоянного личного напряжения» (табл. 3). Однако эта группа довольно многочисленна и охватывает не только новичков, но и тех, кто упрочил свое положение в академических структурах и достиг высокого статуса, что характерно и для некоторых других стран. По дан ным САР, доля преподавателей, разделяющих мнение о стрессе, больше среди тех, кто занимает «младшие» должности, в Австралии, Бразилии, Канаде, Гонконге, Италии, Корее и Португалии.

Относительно высокий уровень стресса, зафиксированный в исследовании Центра Карнеги, объясняется существенной неопределенностью, вызванной радикальными институциональными преобразованиями в сфере высшего образования в начале 1990-х гг. Вероятно, по этой причине в 1992 г. чаще других источником сильного стресса считали свою работу обла-

Рис. 1. Предпочтения "преподавание или научная работа» (данные по всем странам, участвовавшим в проекте САР: 2007-2008, \% от общей численности ответивших)

— Ориентация на научную работу

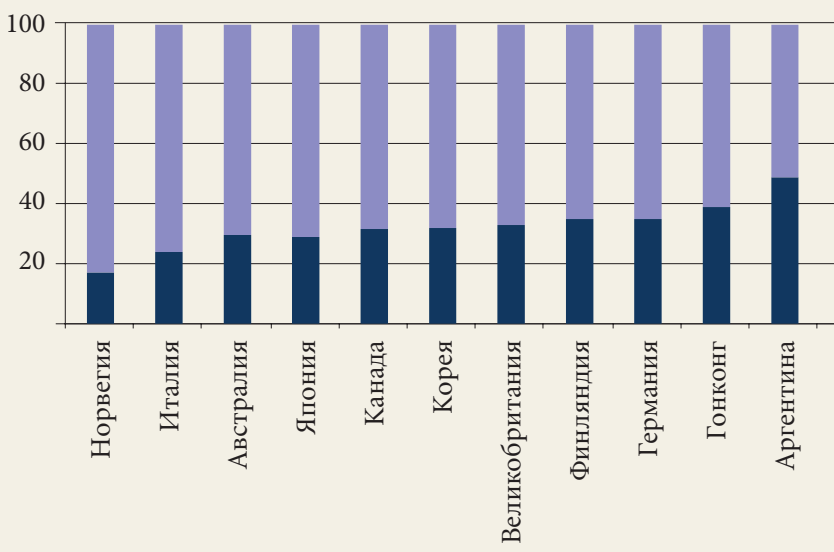

- Ориентация на преподавание

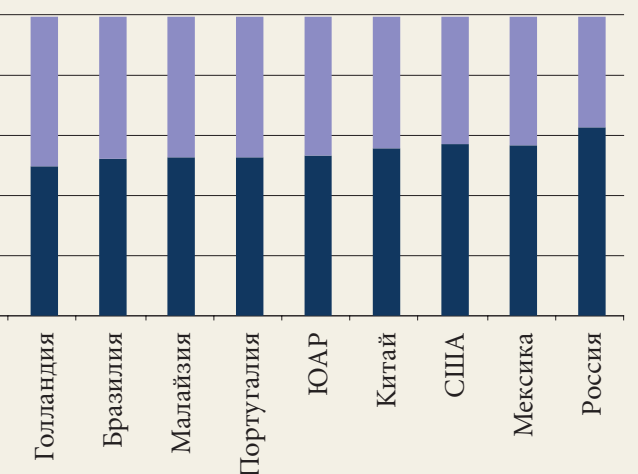

Источник: данные по России - ИНИИ НИУ ВШЭ, другим странам - проект САР [Teichler et al., 2013].

Здесь и далее гипотеза об отсутствии связи между переменными (в данном случае - годом опроса и переменной, указывающей приоритеты преподавателей) проверялась по критерию $\chi^{2}$ (уровень значимости 0.05 ). 


\begin{tabular}{|c|c|c|}
\hline \multicolumn{3}{|c|}{$\begin{array}{c}\text { Табл. з. Отношение к утверждению } \\
\text { «Моя работа для меня - источник } \\
\text { постоянного напряжения» } \\
\text { (\% от общей численности ответивших) }\end{array}$} \\
\hline & 1992 & 2012 \\
\hline Согласен & 51 & 15 \\
\hline Нейтральное отношение & 34 & 21 \\
\hline Не согласен & 15 & 64 \\
\hline Общая численность & 100 (402 чел.) & 100 (686 чел.) \\
\hline
\end{tabular}

датели высоких должностей, рисковавшие в условиях перемен потерять весомый административный и символический капитал.

Напротив, в настоящее время в вузах с особым статусом, как и во всей подвыборке 2012 г., о напряжении преимущественно говорят только обладатели степени бакалавра либо специалиста. Доля тех, кто рассматривает работу как стрессогенный фактор, относительно невелика в когорте докторов наук (7\% как среди преподавателей НИУ, так и во всей подвыборке) и гораздо более заметна среди молодых специалистов (21\% в НИУ, 20\% в подвыборке).

В целом на фоне других государств процент преподавателей, относящихся к указанной группе, незначителен (наименьший среди стран, участвовавших в проекте САР, - рис. 2). Это может объясняться тем, что в академической сфере относительно стабильная (с высокими гарантиями) занятость, отсутствуют связи между заработной платой (впрочем, не заработками) и результатами работы, что свидетельствует о низком уровне конкуренции.

Что более важно, академическая карьера продолжает восприниматься в качестве менее предпочтительной по сравнению с реальным сектором ${ }^{3}$. За период с 1992 г. почти не изменилась доля респондентов, считающих, что сегодня не лучшее время для ее развития (табл. 4). Причины подобных настроений в рамках
Табл. 4. Отношение к утверждению «Настоящее время - далеко не лучшее для молодых людей, чтобы начинать академическую карьеру в моей области знаний» (\% от общей численности ответивших)

\begin{tabular}{|l|c|c|}
\hline & $\mathbf{1 9 9 2}$ & $\mathbf{2 0 1 2}$ \\
\hline Согласен & 32 & 36 \\
\hline Нейтральное отношение & 26 & 24 \\
\hline Не согласен & 42 & 40 \\
\hline Общая численность & $100(377$ чел.) & 100 (686 чел.) \\
\hline
\end{tabular}

Источник: ИНИИ НИУ ВШЭ.

той или иной национальной системы неоднозначны. В частности, в странах с низкой профессорской зарплатой и высокой конкуренцией за места в университетах, встречаются преподаватели, считающие сложившуюся ситуацию благоприятной. Напротив, в некоторых «благополучных» государствах многие опрошенные оценивают нынешние перспективы для новичков довольно скептично (рис. 3).

Обследование показало, что субъективные оценки условий работы у преподавателей сегодня выше, но процент лиц, не жалеющих о выборе карьеры, остался приблизительно таким же (табл. 5). Как и в предыдущем вопросе, распределение ответов не определяется очевидными объективными характеристиками (доходы, сложность поиска постоянной позиции, нагрузка и пр.) (рис. 4).

\section{Оценка качества подготовки}

Современный сравнительно низкий уровень стресса у преподавателей, скорее всего, связан с высокими представлениями о собственной квалификации. Так, около двух третей преподавателей московских и петербургских вузов, охваченных исследованиями САР, считают себя отлично или хорошо подготовленными. Подобная самооценка различается по дисциплинарным областям (относительно ниже у представителей естественных и технических наук, чем у «гуманитариев»

\section{Рис. 2. Распределение мнений респондентов по отношению к утверждению «Моя работа для меня - источник постоянного напряжения» (данные по всем странам, участвовавшим в проекте САР: 2007-2008, \% от общей численности ответивших)}

$$
\text { - Не согласен — Нейтральное отношение Согласен }
$$

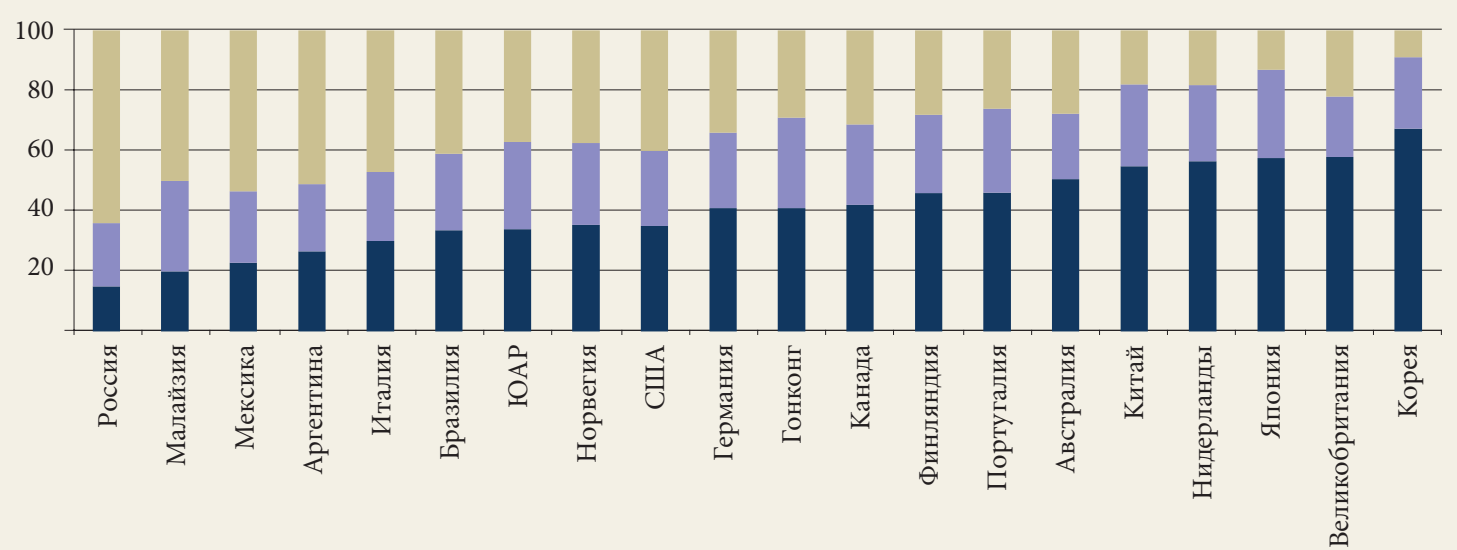

Источник: данные по России - ИНИИ НИУ ВШЭ, другим странам - проект САР [Teichler et al., 2013].

В 2010 г. 8\% опрошенных желали видеть своих детей «профессором, ученым, преподавателем вуза». На вершине рейтинга профессий были «юрист, экономист, финансист», «программист, специалист в области высоких технологий» (по 23\%) и «врач» (22\%) [Левада-центр, 2011] 
Рис. 3. Распределение мнений респондентов по отношению к утверждению «Настоящее время - далеко не лучшее для молодых людей, чтобы начинать академическую карьеру в моей области знаний» (данные по всем странам, участвовавшим в проекте САР: 2007-2008, \% от общей численности ответивших)

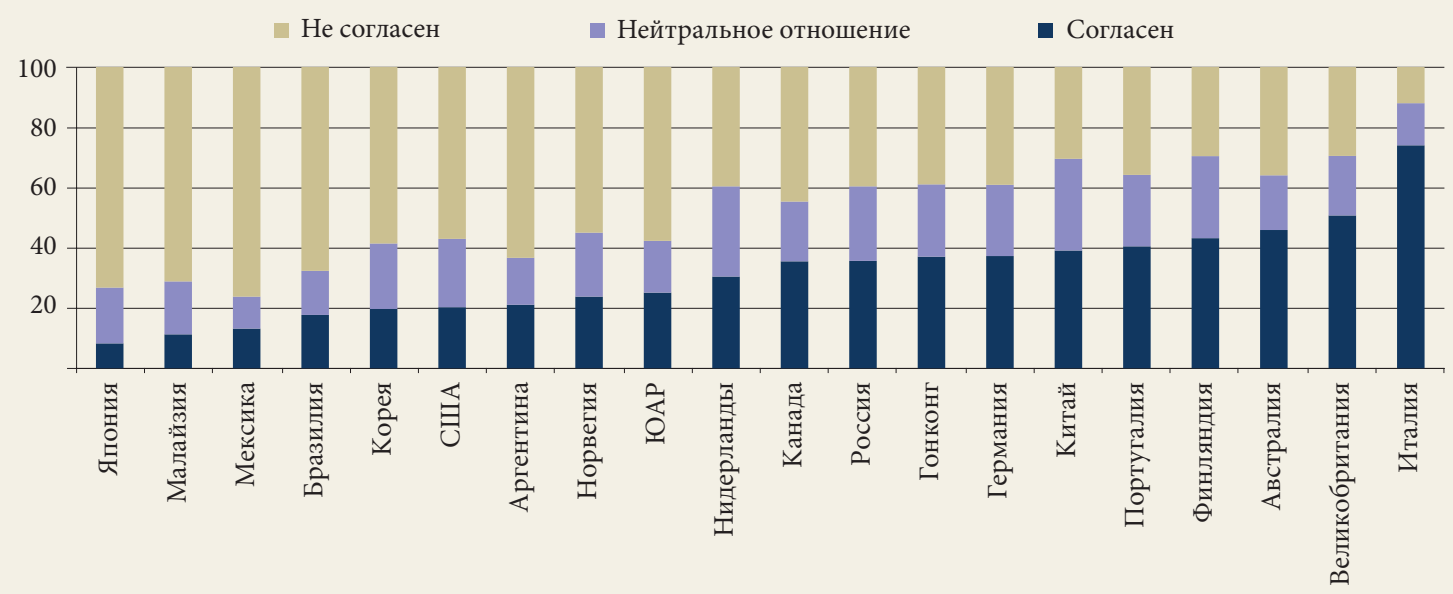

Источник: данные по России - ИНИИ НИУ ВШЭ, другим странам - проект САР [Teichler et al., 2013].

и «социологов»), в то время как двадцатилетием ранее значимых различий выявлено не было.

Уровни публикационной активности преподавателей и интернационализации их деятельности также признаны невысокими, как в среднем по российской выборке, так и по университетам Москвы и Санкт-

\begin{tabular}{|c|c|c|}
\hline & 1992 & 2012 \\
\hline Согласен & 11 & 17 \\
\hline Нейтральное отношение & 17 & 16 \\
\hline Не согласен & 72 & 67 \\
\hline Общая численность & 100 (383 чел.) & 100 (687 чел.) \\
\hline
\end{tabular}

Источник: ИНИИ НИУ ВШЭ.
Петербурга. Двадцать три процента опрошенных отметили, что опубликовали за три года статьи на иностранном языке; $21 \%$ - издали работы за рубежом. Очевидно, что представления людей о глобальной конкурентоспособности не соответствуют реальности. Авторы зарубежных публикаций чаще других склонны высоко оценивать собственную исследовательскую подготовку, тем не менее дифференциация в общем невелика (хотя и статистически значима). Среди тех, кто за последние три года не публиковался в иностранных журналах, свои компетенции считают отличными $44 \%$, а издавших хотя бы одну работу - 56\%. В пользу подобного вывода говорит и тот факт, что серьезных различий в оценках по вузам разных типов (т. е. обладающих особым статусом и остальных) не обнаружено. Впрочем, расхождений в предпочтениях относительно преподавания и исследований у сотрудников «обычных» и «статусных» учебных заведений также не наблюдается [Козьмина, 2013].

\section{Рис. 4. Распределение мнений респондентов по отношению к утверждению «Если бы мне пришлось начинать сначала, я бы не выбрал(а) академическую профессию» (данные по всем странам, участвовавшим в проекте САР: 2007-2008, \% от общей численности ответивших)}

Не согласен - Нейтральное отношение

- Согласен

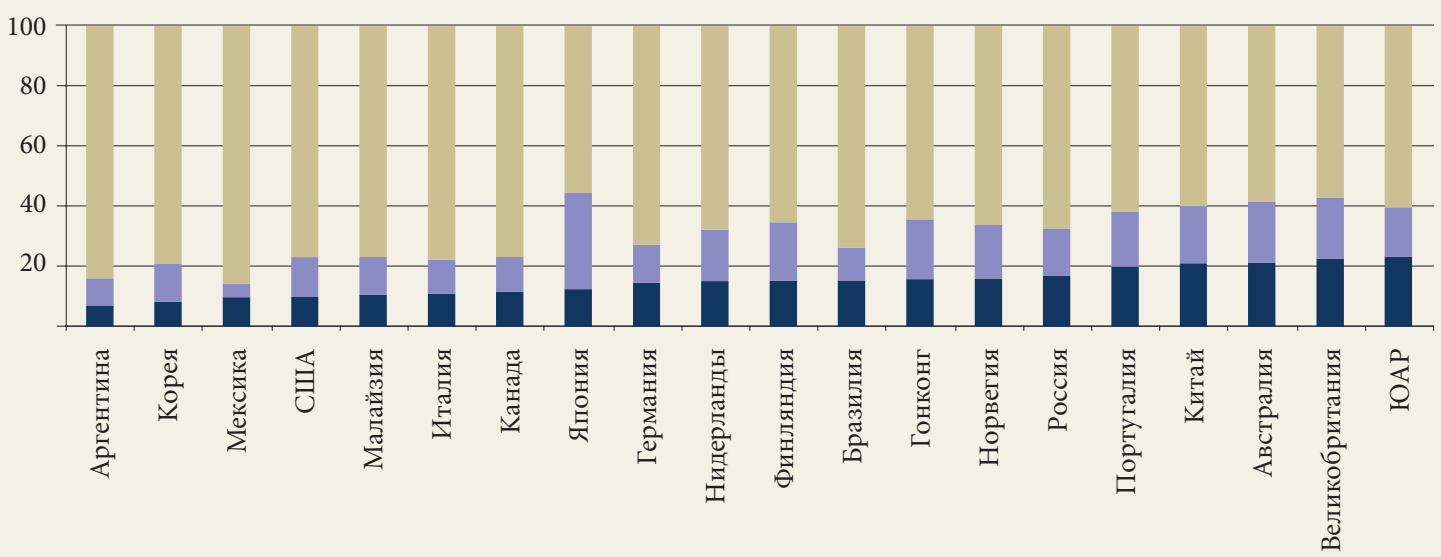


Вопрос: Какую роль играет каждый из перечисленных факторов в Вашем решении о том, оставаться ли в Вашем вузе или уходить из него?

\begin{tabular}{|c|c|c|c|c|}
\hline & \multicolumn{2}{|c|}{$\begin{array}{c}\text { Доля в общей численности } \\
\text { ответивших }(\%)^{*}\end{array}$} & \multicolumn{2}{|c|}{$\begin{array}{c}\text { Общая численность } \\
\text { ответивших (чел.) }\end{array}$} \\
\hline & 1992 & 2012 & 1992 & 2012 \\
\hline Уровень заработной платы & 63 & 25 & 437 & 707 \\
\hline Ресурсы для исследовательской деятельности & 44 & 15 & 437 & 707 \\
\hline Академическая репутация вуза/кафедры & 6 & 13 & 437 & 707 \\
\hline Академическая кооперация среди преподавателей в вузе & 6 & 7 & 437 & 707 \\
\hline
\end{tabular}

* В каждой ячейке указана доля респондентов, отметивших фактор как весомое основание для ухода из вуза (оценки 1 или 2). Баллы начислялись по шкале от 1 до 5, где 1 - веский аргумент в пользу ухода, 5 - продолжения работы. Сумма долей превышает 100\%, так как респонденты могли выбрать несколько вариантов ответов.

Источник: ИНИИ НИу ВШЭ.

\section{Факторы, стимулирующие уход из университета либо развитие академической карьеры}

Веским основанием для выхода из профессии и в 1992 г., и в 2012 г. являлся уровень заработной платы, но ныне он уже не считается столь критичным (данный ответ выбрали 25\% респондентов, тогда как 20 лет назад их было 63\%) (табл. 6).

Самым значимым аргументом в пользу того, чтобы остаться в университете, оказалась академическая репутация вуза либо кафедры, хотя к 2012 г. в этом отношении преподаватели стали менее «единодушны» (табл. 7). Заметно меньшую роль в качестве фактора ухода из вуза стала играть проблема слабой ресурсной обеспеченности. В 1992 г., при низком уровне заработной платы и ограниченном доступе к необходимым ресурсам, основной мотивацией к развитию карьеры служили репутация университета (кафедры) и кооперация между преподавателями, что отметили 86 и 83\% опрошенных соответственно. Приведенные показатели согласуются с наблюдениями в отношении иных факторов, определяющих степень удовлетворенности работой [Lacy, Sheehan, 1997; Barnes et al., 1998]. В этих исследованиях отмечается, что едва ли не решающими «удерживающими» стимулами выступают «чувство сообщества» и хорошие отношения с коллегами. Однако в настоящий момент упомянутые факторы «работают» для гораздо меньшего количества преподавателей.

\section{Модели принятия решений}

Анализ роли разных категорий сотрудников университета в принятии важных решений и оценка преподавателями степени собственного участия в этих процессах позволяют сделать вывод о существенной их централизации в сочетании со стабильностью такой модели (табл. 8 и 9). В выборках обоих рассматриваемых обследований отмечается централизация в определении приоритетов при распределении вузовского бюджета, избрании ключевых руководителей и установлении критериев приема первокурсников. В меньшей степени, по мнению представителей обеих выборок, это касается «повышения» работающих и избрания на должности новых преподавателей и сотрудников.

Заметим, что в федеральных университетах и НИУ роль централизованного руководства (на уровне ректората) в принятии базовых решений (избрание ключевых руководителей вуза или определение приоритетов в распределении бюджета) выше, чем в «обычных» учреждениях высшего образования.

На первый взгляд, эти данные противоречат заключениям ряда работ, изучающих взаимосвязь моделей управления и развития академической среды [Masten, 2006, и др.]. В последних отмечается, что опора на академическое самоуправление (shared governance) в большей степени необходима и востребована в секторе исследовательских университетов, в то время

\section{табл. 7. Основания для продолжения работы в вузе}

Вопрос: Какую роль играет каждый из перечисленных факторов в Вашем решении о том, оставаться ли в Вашем вузе или уходить из него?

\begin{tabular}{|l|c|c|c|c|}
\hline & \multicolumn{2}{|l|}{$\begin{array}{c}\text { Доля в общей численности } \\
\text { ответивших (\%) }\end{array}$} & \multicolumn{2}{c|}{$\begin{array}{c}\text { Общая численность } \\
\text { ответивших (чел.) }\end{array}$} \\
\cline { 2 - 4 } & $\mathbf{1 9 9 2}$ & $\mathbf{2 0 1 2}$ & $\mathbf{1 9 9 2}$ & $\mathbf{2 0 1 2}$ \\
\hline Уровень заработной платы & 20 & 40 & 437 & 707 \\
\hline Ресурсы для исследовательской деятельности & 25 & 40 & 437 & 707 \\
\hline Академическая репутация вуза/кафедры & 86 & 46 & 437 & 707 \\
\hline Академическая кооперация среди преподавателей в вузе & 83 & 41 & 437 \\
\hline Регион, в котором расположен вуз & 78 & 68 & 437 & 707 \\
\hline
\end{tabular}

* В каждой ячейке указана доля респондентов, отметивших фактор как весомое основание для продолжения работы в вузе (оценки 4 или 5). Баллы начислялись по шкале от 1 до 5, где 1 - веский аргумент в пользу ухода, 5 - продолжения работы. Сумма долей превышает 100\%, так как респонденты могли выбрать несколько вариантов ответов. 
Табл. 8. Как принимаются различные решения в вузе: 1992 (\% от общей численности ответивших)

Вопрос: Как происходит принятие решений в вашем вузе (оцените по шкале от 1 до 5, где 1 - иентрализованно, 5 - децентрализованно) ? вузовского бюджета

Степень централизации (в баллах от 1 до 5)

Избрание ключевых руководителей вуза

\begin{tabular}{l|l|l|l|}
$\mathbf{2}$ & $\mathbf{3}$ & $\mathbf{4}$ & $\mathbf{5}$ \\
\hline 20 & 10 & 1 & 2 \\
\hline 19 & 19 & 2 & 1 \\
\hline 22 & 16 & 3 & 4 \\
\hline 23 & 22 & 8 & 4 \\
\hline 20 & 31 & 9 & 8 \\
\hline 23 & 39 & 8 & 7 \\
\hline 17 & 40 & 15 & 9 \\
\hline
\end{tabular}

Выбор критериев приема первокурсников

1

\begin{tabular}{l|l}
1 \\
67
\end{tabular}

Определение общей учебной нагрузки преподавателей

Утверждение новых образовательных программ

Повышение преподавателей в должности

Избрание новых преподавателей или научных сотрудников

Общая численность ответивших

Источник: ИНИИ НИУ ВШЭ.

\section{Табл. 9. Как принимаются различные решения в вузе: 2012 (\% от общей численности ответивших)}

Вопрос: Кто в Вашем вузе, по Вашему мнению, обладает наибольшим весом при принятии перечисленных решений?

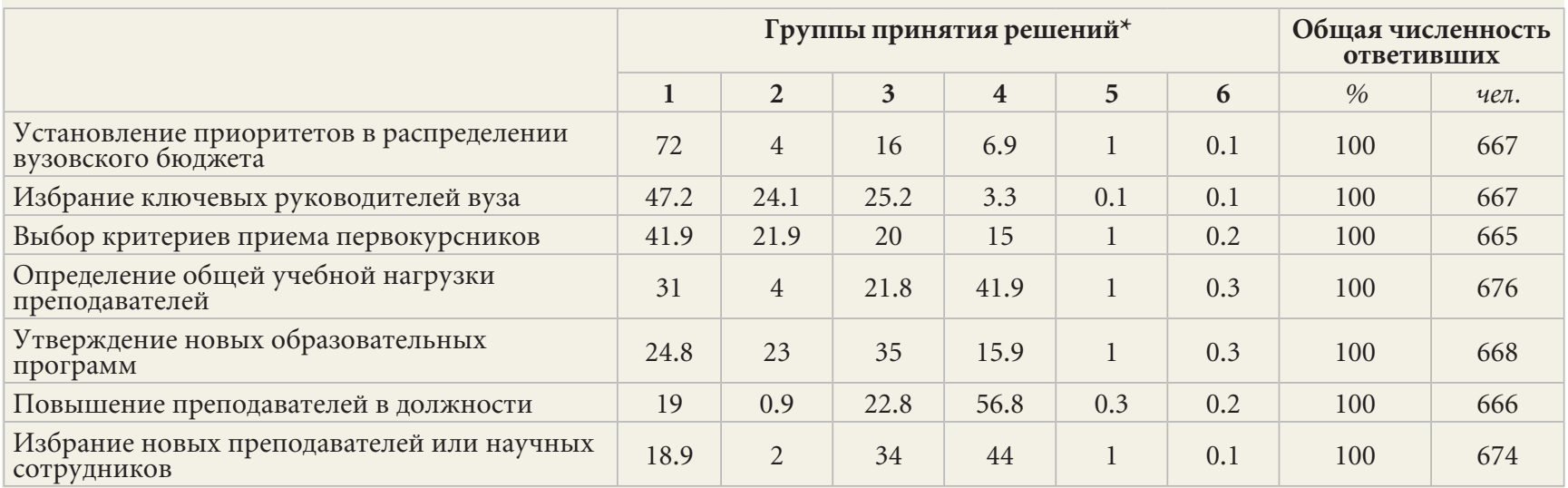
сотрудников

* Варианты ответа: 1 - ректорат; 2 - государственное министерство/ведомство или совет попечителей; 3 - ученые советы и комиссии с участием представителей профессорско-преподавательского состава; 4 - деканы и заведующие кафедрами; 5 - отдельные преподаватели; 6 - студенты.

Источник: ИНИИ НИУ ВШЭ.

как в университетах и колледжах, ориентированных на преподавание, управление более централизованно. На самом деле, подобное противоречие иллюзорно: указанные работы базируются преимущественно на данных по рынку высшего образования США, где статус исследовательского университета (согласно классификации Карнеги ${ }^{4}$ ) устанавливается по объективным показателям текущей результативности. В то же время, российским учреждениям он присваивался под специальные программы развития, требующие мобилизации человеческих ресурсов для скорейшего достижения заявленных показателей. Именно поэтому в таких вузах присутствуют элементы «мобилизационной» модели управления. Собственное влияние в принятии решений преподаватели, как и 20 лет назад, по-прежнему считают достаточно невысоким (табл. 10).

\section{Табл. 10. Оценка преподавателями собственного влияния в принятии академических решений (\% от общей численности ответивших)}

Вопрос: Насколько влиятельным(ой) в принятии основных академических решений на каждом из следуюших уровней Вы лично ощущаете себя?

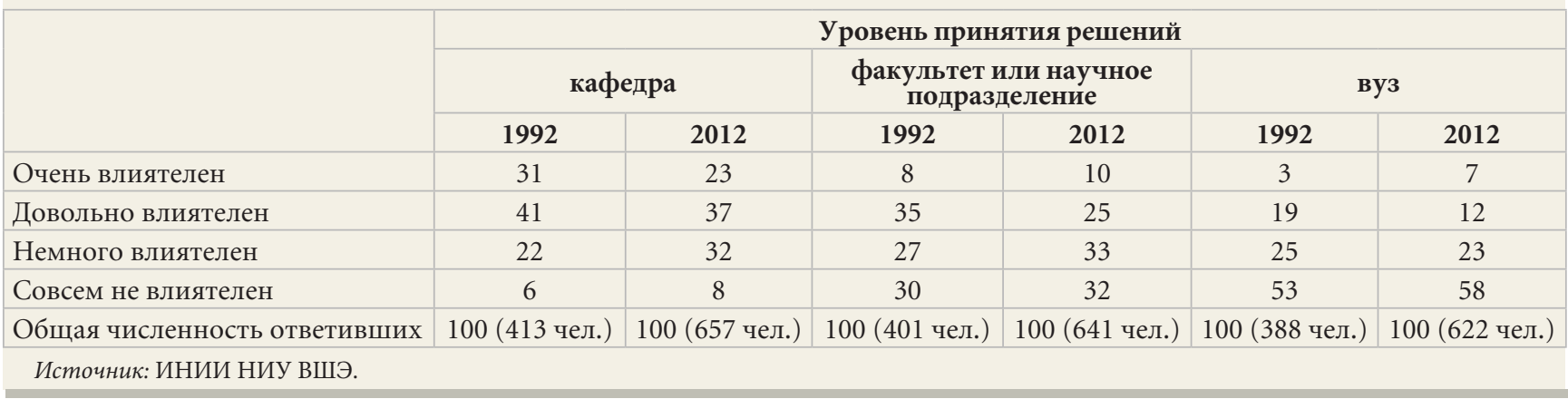

\footnotetext{
${ }^{4}$ Режим доступа: http://classifications.carnegiefoundation.org/methodology/basic.php, дата обращения 14.06.2013.
} 
Вопрос: Кто из перечисленных категорий лии участвует в регулярной оценке и аттестации Вашей учебной, научной и административной работы?

\begin{tabular}{|c|c|c|c|c|c|c|}
\hline & \multicolumn{4}{|c|}{ Доля в общей численности ответивших (\%)* } & \multirow{2}{*}{\multicolumn{2}{|c|}{$\begin{array}{c}\text { Общая численность } \\
\text { ответивших (чел.) }\end{array}$}} \\
\hline & \multicolumn{2}{|c|}{ учебная работа } & \multicolumn{2}{|c|}{ научная работа } & & \\
\hline & 1992 & 2012 & 1992 & 2012 & 1992 & 2012 \\
\hline Коллеги по кафедре/научному подразделению & 20 & 84 & 15 & 59 & 437 & 603 \\
\hline $\begin{array}{l}\text { Заведующий кафедрой/руководитель научного } \\
\text { подразделения }\end{array}$ & 47 & 80 & 25 & 75 & 437 & 655 \\
\hline $\begin{array}{l}\text { Сотрудники других кафедр или кафедр других } \\
\text { факультетов Вашего вуза }\end{array}$ & 9 & 40 & 8 & 53 & 437 & 340 \\
\hline $\begin{array}{l}\text { Высшее руководство Вашего вуза (ректорат, } \\
\text { деканат) }\end{array}$ & 13 & 58 & 10 & 51 & 437 & 525 \\
\hline Студенты & 40 & 86 & 2 & 18 & 437 & 460 \\
\hline Внешние рецензенты & 3 & 25 & 24 & 77 & 437 & 342 \\
\hline
\end{tabular}

* Сумма долей превышает 100\%, так как респонденты могли выбрать несколько вариантов ответов.

Источник: ИНИИ НИУ ВШЭ.

С ростом ранга в академической иерархии увеличивается ощущение вовлеченности в управление на всех уровнях (от отдельной кафедры либо факультета до общевузовского), но в целом оно остается довольно низким.

\section{Контроль и конкуренция}

Характерной особенностью сложившейся в университетском секторе обстановки является то, что существенно больше респондентов (по сравнению с ситуацией двадцатилетней давности) отметили наличие регулярного контроля за своей деятельностью (табл. 11). Преподавателями он отмечается со стороны как коллег и непосредственных начальников, так и ректората (хотя и в меньшей степени по сравнению с контролем со стороны заведующего кафедрой или декана) и студентов.

С учетом этих данных и динамики за 20 лет нельзя утверждать, что изменения соответствуют тенденции «нового менеджериализма», отличающегося, в том числе, переходом от внутреннего контроля академическим сообществом и администрацией к внешне му наблюдению [Brennan, 2007; Deem, 1998]. Однако в целом, вероятно, значительно большие цифры по всем пунктам свидетельствуют о недовольстве таким усилением контроля. Роль внешнего давления и независимого рецензирования остается сравнительно невысокой: о ней упоминают сегодня лишь четверть респондентов.

Табл. 12. Отношение к утверждению «Высокие требования по увеличению научной продуктивности угрожают качеству научной работы» (\% от общей численности ответивших)

\begin{tabular}{|c|c|c|}
\hline & 1992 & 2012 \\
\hline Согласен & 9 & 50 \\
\hline Нейтральное отношение & 38 & 30 \\
\hline Не согласен & 53 & 20 \\
\hline Общая численность & 100 (405 чел.) & 100 (668 чел.) \\
\hline
\end{tabular}

В нынешней ситуации статусные вузы отличаются от остальных. Среди представителей НИУ большинство называют «оценщиками» преподавательской работы заведующего кафедрой (84\% против 76\% в категории «остальных вузов»), самого преподавателя (85 и 73\%) и студентов (92 и 80\%, соответственно). Наоборот, в данной группе меньше тех, чью научную результативность контролирует заведующий кафедрой (70 и 79\%), а административную деятельность - внешние рецензенты (7 и 15\%). При этом многие уверены, что постоянный контроль и высокие требования по увеличению научной продуктивности негативно отражаются на исследовательской работе (табл. 12).

\section{Приоритеты высшего образования}

При том что базовые установки преподавателей российских вузов во многом остались неизменными, в течение рассматриваемого периода трансформировалось восприятие самой миссии системы высшего образования (табл. 13). Если в 1992 г. респонденты чаще упоминали задачу подготовки студентов к успешному выходу на рынок труда, то теперь более значимым приоритетом видится усиление конкурентного потенциала страны на международном уровне.

\section{Заключение}

Сравнение результатов опросов, разделенных двадцатилетним промежутком (за который отечественная система высшего образования претерпела коренные изменения), дало возможность выявить как относительно стабильные, так и трансформировавшиеся характеристики академической профессии и отношения к ней со стороны преподавателей. Последние по-иному стали рассматривать свою работу: в подавляющем большинстве они не считают ее источником постоянного напряжения. Вероятно, акценты в профессиональной деятельности начинают понемногу смещаться в сторону науки. Сменилась иерархия стимулов, побуждающих к развитию карьеры в академической профессии либо выходу из нее, что обусловлено улучшением финансовых условий (как в плане зарплаты, так и требуемых для исследований ресурсов), с одной стороны, и разрушением сильных академических команд - с другой. Вместе с тем, опреде- 
Вопрос: Если заглядывать в будущее, какой приоритет, на Ваш взгляд, в системе высшего образования в России должен отдаваться каждой из перечисленных задач?

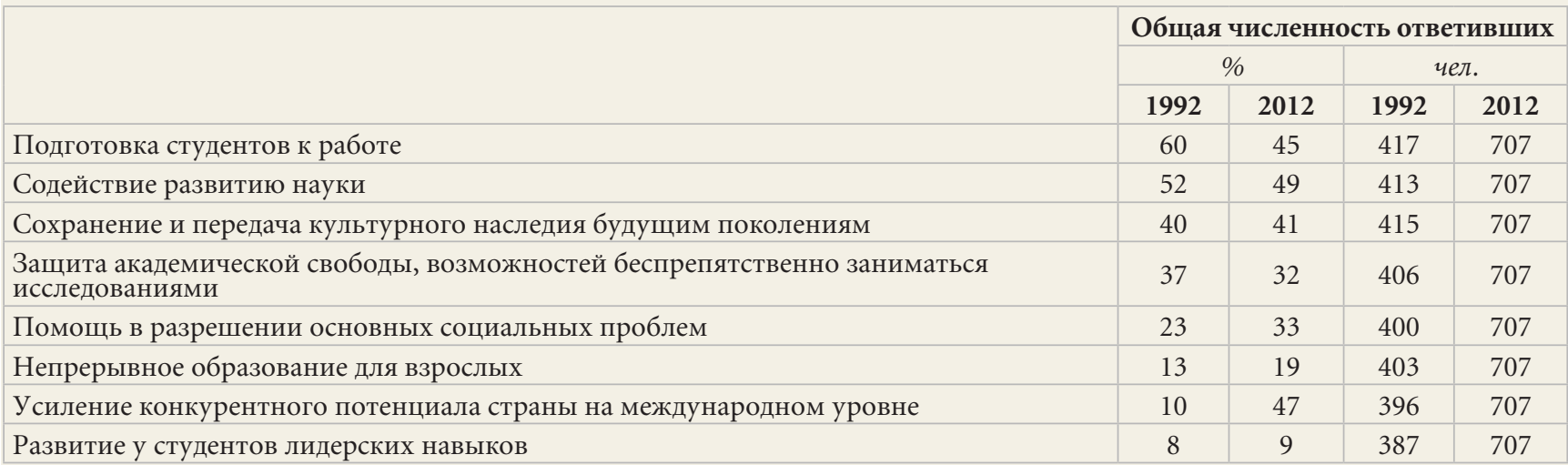

* Сумма долей превышает 100\%, так как респонденты могли выбрать несколько вариантов ответов.

Источник: ИНИИ НИУ ВШЭ.

ленные значимые параметры системы отличаются относительной стабильностью: неизменной осталась доля сомневающихся в перспективах своей профессии и считающих сегодняшнее время не лучшим для вхождения в нее. В среднем, сохранились сложившиеся структуры управления, а вовлеченность преподавателей в процессы принятия решений остается низкой. Нет оснований говорить о том, что университеты сдвигаются в сторону модели академического самоуправления.
Меняются и приоритеты высшего образования: если 20 лет назад одной из центральных задач виделась подготовка студентов к выходу на рынок труда, теперь же на первый план выходит укрепление позиций России в глобальном сообществе. Подобный сдвиг прогнозируемый, но настораживает тот факт, что он единственное (и достаточно эфемерное) свидетельство адаптации академической культуры к идее конкуренции в глобальном академическом пространстве.

Козьмина Я.Я. (2013) Научная и преподавательская деятельность ППС российских вузов: предпочтения, затрачиваемое время и академическая продуктивность. М.: НИУ ВШЭ (тіmео).

Левада-центр (2011) Общественное мнение - 2010. Ежегодник. М.: Аналитический центр Юлия Левады («Левада-центр»).

Altbach P., Androuschak G., Kuzminov Y., Yudkevich M., Reisberg L. (eds.) (2013) The Global Future of Higher Education and the Academic Profession. London: Palgrave McMillan.

Altbach P. (ed.) (1996) International Academic Profession. Portraits of Fourteen Countries. San Francisco, CA: Jossey-Bass Publishers.

Altbach P., Reisberg L., Yudkevich M., Androushchak G., Pacheco I. (eds.) (2012) Paying the Professoriate. A Global Comparison of Compensation and Contracts. London: Routledge.

Barnes L.B., Agago M.O., Coombs W.T. (1998) Effects of Job-Related Stress on Faculty Intention to Leave Academia // Research in Higher Education. № 39. P. 457-469.

Brennan J. (2007) The Academic Profession and Increasing Expectations of Relevance // Key Challenges to the Academic Profession / Eds. M. Kogan, U. Teichler. Paris, Kassel: UNESCO Forum on Higher Education Research and Knowledge, INCHER, Kassel. P. 19-28. Режим доступа: http://portal.unesco.org/education/en/files/54977/11970234265Key_Challanges_Academic_Profession_ REV.pdf/Key_Challanges_Academic_Profession_REV.pdf, дата обращения 08.05.2013.

Deem R. (1998) «New Managerialism» and Higher Education: The Management of Performances and Cultures in Universities in the United Kingdom // International Studies in Sociology of Education. Vol. 8. № 1. P. 47-70. Режим доступа: http://www.tandfonline.com/doi/pdf/10.1080/096202198002001, дата обращения 19.04.2013.

Gottlieb E., Keith B. (1997) The academic research-teaching nexus in eight advanced industrialized countries // Higher Education. Vol. 34. № 3. P. 397-420.

Lacy F.J., Sheehan B.A. (1997) Job Satisfaction among Academic Staff: An International Perspective // Higher Education. Vol. 34 . № 3. P. 305-322.

Masten S. (2006) Authority and Commitment: Why Universities, Like Legislatures, Are Not Organized As Firms // Journal of Economics and Management Strategy. № 15. P. 649-684.

Shin J.C., Arimoto A., Cummings W.K., Teichler U. (eds.) (2013) Teaching and Research in Contemporary Higher Education. Systems, Activities and Rewards. New-York, London: Springer.

Teichler U., Arimoto A., Cummings W. (2013) The Changing Academic Profession. Major Findings of a Comparative Survey. New-York, London: Springer. 


\title{
Academic Profession in a Comparative Perspective: 1992-2012
}

\author{
Elizaveta Sivak \\ Junior Research Fellow. E-mail: elizaveta.sivak@gmail.com
}

\section{Maria Yudkevich}

Director. E-mail: yudkevich@hse.ru

Center for Institutional Studies, National Research University - Higher School of Economics

Address: National Research University - Higher School of Economics, 20, Myasnitskaya str., Moscow, 101000, Russian Federation.

\begin{abstract}
$\mathrm{O}$ ver the past two decades, the higher education sector in Russia has undergone profound institutional changes that have especially affected the academic profession. This paper studies the dynamics of key characteristics of the academic profession in Russia. We use data on Russian university faculty from two largescale comparative studies of the academic profession (the «International Academic Profession», a study carried out by the Carnegie Center in 1992 in 14 countries, including Russia [Altbach, 1996], and the "Changing Academic Profession", a study implemented in 2007, with 19 participating countries, including Russia, in 2012 [Teichler et al., 2013]) to look at how faculty attitudes on aspects of academic life changed over 20 years (1992-2012): for instance faculty views on reasons for leaving or staying at the university, on university management and on the faculty's role in decision making. We also use the international dataset from the «Changing

Academic Profession» to compare Russian faculty to those in other countries. The article provides an analysis of teaching/ research preferences, views on the personal strain associated with work, and academic career perspectives for Russian universities (1992 and 2012) in comparison with those of other countries.

One of the main conclusions is that the high degree of overall centralization of governance in Russian universities has barely changed in 20 years. This undermines talk of universities' shift towards academic self-governance. The basic attitudes of university faculties are in many ways the same over twenty years, although perception of the mission of higher education has changed. Previously the mission was to prepare students for a successful professional career, now the priority is seen in strengthening the country's position at the international level. One can hardly argue, however, that universities are in a position to implement this new mission.
\end{abstract}

\section{Keywords}

academic profession; higher education; academic contracts; university governance; research and teaching nexus; research universities

\section{References}

Altbach P., Androuschak G., Kuzminov Y., Yudkevich M., Reisberg L. (eds.) (2013) The Global Future of Higher Education and the Academic Profession, London: Palgrave McMillan.

Altbach P. (ed.) (1996) International Academic Profession. Portraits of Fourteen Countries, San Francisco, CA: Jossey-Bass Publishers.

Altbach P., Reisberg L., Yudkevich M., Androushchak G., Pacheco I. (eds.) (2012) Paying the Professoriate. A Global Comparison of Compensation and Contracts, London: Routledge.

Barnes L.B., Agago M.O., Coombs W.T. (1998) Effects of Job-Related Stress on Faculty Intention to Leave Academia. Research in Higher Education, no 39, pp. 457-469.

Brennan J. (2007) The Academic Profession and Increasing Expectations of Relevance. Key Challenges to the Academic Profession (eds. M. Kogan, U. Teichler), Paris, Kassel: UNESCO Forum on Higher Education Research and Knowledge, INCHER, Kassel. P. 19-28. Available at: http://portal.unesco.org/education/en/files/54977/11970234265Key_Challanges_Academic_Profession_REV.pdf/Key_Challanges_Academic_ Profession_REV.pdf, accessed 08.05.2013.

Deem R. (1998) «New Managerialism» and Higher Education: The Management of Performances and Cultures in Universities in the United Kingdom. International Studies in Sociology of Education, vol. 8, no 1, pp. 47-70. Available at: http://www.tandfonline.com/doi/ pdf/10.1080/096202198002001, accessed 19.04.2013.

Gottlieb E., Keith B. (1997) The academic research-teaching nexus in eight advanced industrialized countries. Higher Education, vol. 34, no 3, pp. 397-420.

Kozmina Y. (2013) Nauchnaya i prepodavatel'skaya deyatel'nost' PPS rossiiskikh vuzov: predpochteniya, zatrachivaemoe vremya i akademicheskaya produktivnost' [Research and Teaching Activities of PPP Russian Universities: Preferences, Time Spent and Academic Productivity], Moscow: HSE (mimeo).

Lacy F.J., Sheehan B.A. (1997) Job Satisfaction among Academic Staff: An International Perspective. Higher Education, vol. 34, no 3, pp. 305-322.

Levada-Center (2011) Obshchestvennoe mnenie - 2010. Ezhegodnik [Public Opinion - 2010. Yearbook], Moscow, Yury Levada Analytical Center (Levada-Center).

Masten S. (2006) Authority and Commitment: Why Universities, Like Legislatures, Are Not Organized As Firms. Journal of Economics and Management Strategy, no 15, pp. 649-684.

Shin J.C., Arimoto A., Cummings W.K., Teichler U. (eds.) (2013) Teaching and Research in Contemporary Higher Education. Systems, Activities and Rewards, New-York, London: Springer.

Teichler U., Arimoto A., Cummings W. (2013) The Changing Academic Profession. Major Findings of a Comparative Survey, New-York, London: Springer. 


\title{
Типология и анализ научно-образовательной результативности российских вузов
}

\author{
И.В. Абанкина', Ф.Т. Алескеров", В.Ю. Белоусова'II, Л.М. Гохбергі", \\ К.В. Зиньковскийㄱ, С.Г. Кисельгоф ${ }^{\mathrm{VI}}$, С.В. Швыдун ${ }^{\mathrm{VII}}$
}

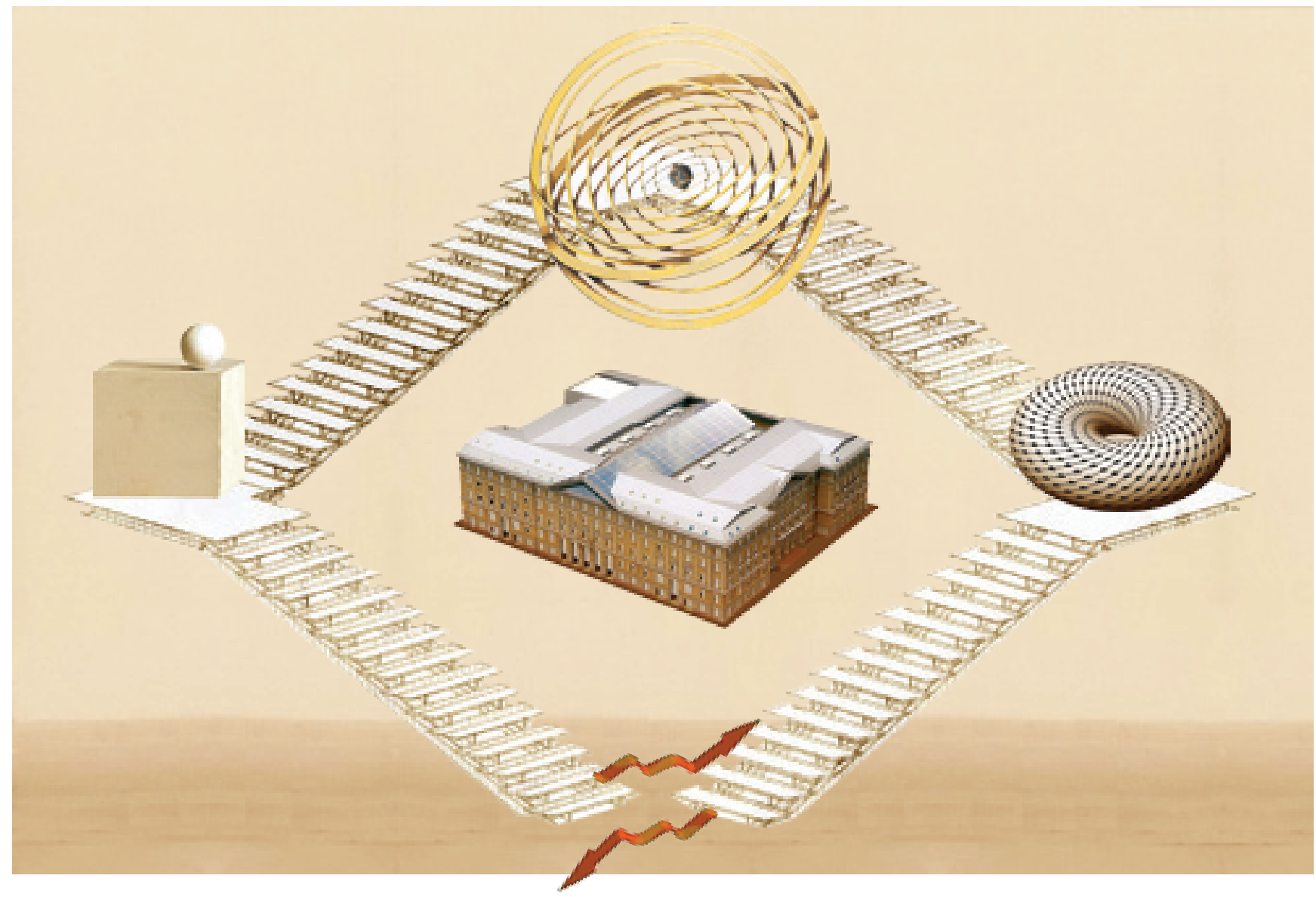

Усиление экономического давления и растущие ожидания государства и общества стимулируют университеты к финансовой самостоятельности и повышению эффективности за счет диверсификации видов деятельности.

В статье предлагается классификация, позволяющая оценить результативность научной и образовательной активности российских вузов. Она может служить основой для содержательного анализа разнородной их совокупности и выработки адресных мер политики, адаптированных к специфике каждой из выделенных групп.

\footnotetext{
Исследование подготовлено в рамках проекта «Формирование системы мониторинга экономики науки для оценки состояния сферы науки и технологий и демонстрации новых научных достижений» (государственный контракт Минобрнауки России от 26 сентября 2011 г. № 13.521.12.1011). Работа была частично поддержана Международной научно-учебной лабораторией анализа и выбора решений, Лабораторией экономики инноваций ИСИЭЗ и Институтом развития образования в рамках Программы фундаментальных исследований НИУ ВШЭ в 2012 г.
}

I Абанкина Ирина Всеволодовна - директор, Институт развития образования (ИРО). E-mail: abankinai@hse.ru II Алескеров Фуад Тагиевич - руководитель Департамента математики, факультет экономики, заведующий Международной научно-учебной лабораторией анализа и выбора решений. E-mail: alesk@hse.ru

III Белоусова Вероника Юрьевна - заведующий отделом методологии бюджетного планирования, Институт статистических исследований и экономики знаний (ИСИЭЗ). E-mail: vbelousova@hse.ru

Iv Гохберг Леонид Маркович - директор, Институт статистических исследований и экономики знаний (ИСИЭЗ), первый проректор. E-mail: lgokhberg@hse.ru

v Зиньковский Кирилл Викторович - заместитель директора, Институт развития образования (ИРО).

E-mail: kzinkovsky@hse.ru

${ }^{\mathrm{VI}}$ Кисельгоф Софья Геннадьевна - преподаватель Департамента математики, факультет экономики. E-mail: skiselgof@hse.ru

VII Швыдун Сергей Владимирович - стажер-исследователь, Международная научно-учебная лаборатория анализа и выбора решений. E-mail: shvydun@hse.ru

Национальный исследовательский университет «Высшая школа экономики»

Адрес: Национальный исследовательский университет «Высшая школа экономики», 101000, Москва, Мясницкая ул., 20

\section{Ключевые слова}

высшие учебные заведения; типология; оценка эффективности; научная и образовательная деятельность вузов; иерархическая кластеризация 
3 а последние десятилетия организационный ландшафт высшего образования заметно изменился и стал более разнородным. Об этом свидетельствуют усложнение организационных структур университетов, увеличение числа и расширение многообразия образовательных программ, их выход на международные рынки, появление новых видов деятельности и предпринимательских инициатив. Указанные процессы в значительной степени стимулируются государством и другими стейкхолдерами, включая конечных потребителей образовательных услуг - работодателей и население. Формируется (а во многих странах уже внедрена) многоканальная система финансирования вузов, в рамках которой значительная его часть перекладывается как на частных потребителей, так и на структуры, инвестирующие в фундаментальную и прикладную науку. Меняется фокус государственной поддержки - от обеспечения текущего функционирования университетов к оплате конечного результата (выпуска специалистов). В ряде стран мира недавние экономические потрясения привели к сокращению прямого государственного финансирования вузов. До определенного момента оно уменьшалось и в России, но сейчас претерпевает беспрецедентный рост. Упомянутые вызовы наряду с усилением отраслевой конкуренции способствуют появлению разнообразных стратегий адаптации и развития университетов в новых условиях и соответственно диверсификации их типов. Между тем, существующие международные и национальные рейтинги не позволя ют классифицировать вузы по типам, хотя работы по разработке и внедрению соответствующих типологий проводятся во многих странах.

Мы предприняли попытку создать эмпирически обоснованную типологию российских государствен ных вузов, базирующуюся на достоверной информации об их деятельности, с учетом индикаторов научной и инновационной активности. В ходе исследования был проведен сравнительный анализ существующих типологий, на которые ссылаются зарубежные и оте чественные специалисты. Сформирована база данных, включающая показатели образовательной, научной и инновационной деятельности университетов, и произведена ее статистическая обработка, благодаря чему изучаемые объекты были сгруппированы по общности признаков. В итоге предложена классификация вузов и выполнен анализ результативности их деятельности применительно к тем или иным выделенным группам.

\section{Международный опыт типологизации университетов}

Международная практика свидетельствует о наличии двух принципиально разных подходов к классификации образовательных учреждений. Первый фиксирует текущее положение дел. В этом случае вузы разделяются на группы в зависимости от параметров их деятельности, уровня обучения (бакалавриат, магистратура), спектра изучаемых дисциплин и т. п. Недостаток подобного подхода в том, что университетам, стремящимся к росту, но пока не достигшим необходимого уровня, присваивается ярлык «невысо- кого качества», и это негативно влияет на их дальнейшее развитие.

Согласно второму принципу, образовательные учреждения группируются в соответствии с потенциалом стратегического развития, с учетом динамики изменений, возможностей и стремления к росту. Речь идет о развитии образовательных программ, научных и инновационных проектов.

Кроме этого, выделяются два кардинально различающихся метода построения типологии, основанные либо на экспертном определении критериев классификации и пороговых значений параметров, позволяющих выявлять тип высшего учебного заведения, либо на использовании математических моделей кластеризации. В свою очередь, применяемый математический аппарат дает возможность дифференцировать образовательные учреждения по кластерам таким образом, что каждый из них оказывается достаточно однородным, а отличия между кластерами - значительными.

\section{Фонд Карнеги (США)}

Одна из наиболее известных систем группировки университетов - классификация Фонда Карнеги, созданная в США в 1970 г. для исследовательских целей. На американском образовательном рынке традиционно присутствует большое число вузов самого разного профиля и размера. Изучение деятельности университетов потребовало их деления на более или менее однородные группы. Классификация постепенно совершенствовалась и к настоящему времени стала одним из авторитетнейших инструментов анализа активности и производительности образовательных учреждений. Она дает возможность учесть оценку «качества» заведения абитуриентами и государственными ведомствами, принимать решения о предоставлении грантов, включении в консорциумы и т. п.

До 2005 г. эта классификация была одномерной, то есть каждый ее субъект причислялся к конкретному типу. В отдельных случаях она выявляла превосходство одной категории над другой, ранжируя их в соответствии с убыванием параметров качества и тем самым выполняя, пусть и частично, функции рейтинга. В связи с этим некоторые университеты стремились войти в определенную категорию, установленную в данной классификации.

С 2005 г. классификация Фонда Карнеги поменяла свою форму принципиальным образом. В последней ее версии обозначен ряд критериев, по каждому из которых вузам присваивается соответствующая категория, что позволяет учесть многоаспектность их деятельности. В настоящее время в ней применяются следующие признаки классификации [McCormick, Zhao, 2005]:

- классическая типология Фонда Карнеги по качеству предоставляемого образования и исследовательской деятельности;

- тип преподавания (ранжирование осуществляется отдельно для бакалаврских и магистерских/PhD программ);

- профиль учащихся: структура и «качество» абитуриентов, удельный вес «очников» в общей численности и т. п.; 
- размер и окружение: совокупная популяция обучающихся, места их проживания (местные/приезжие).

В дополнение могут учитываться сведения, характеризующие распространение в вузах лучших практик и предоставляемые ими на добровольной основе.

\section{Европейский Союз}

В Европе не существует единого подхода к классификации университетов. В рамках Болонского процесса процедура выдачи степеней была унифицирована, однако в ряде стран, во многом исходя из исторических традиций, по-прежнему используются специальные национальные классификации учреждений среднего профессионального и высшего образования. Тем не менее в политических кругах и академическом сообществе активно обсуждаются вопросы создания единой типологии. В рамках этого процесса в 2005 г. был предложен примерный набор параметров, которые могли бы лечь в основу гармонизированной классификации (табл. 1).

Наряду с результатами других исследований указанные индикаторы использовались в проекте Университета Твенте (Нидерланды) [Bartelse, van Vught, 2007], который был реализован при поддержке Европейской комиссии в целях формирования общеевропейской типологии. К настоящему моменту создана альтернативная система оценивания. Она предусматривает организацию сбора данных посредством специальных мониторингов, предполагающих добровольное заполнение анкет представителями вузов. При построении типологии учитывается страновая специфика. Пороговым условием для включения вузов в классификацию является наличие хотя бы одной образовательной программы, сертифицированной государством. До настоящего времени разработка типологии университетов не завершена, однако удалось сформировать список параметров, сгруппированных по тематическим разделам. Вызывает интерес подход авторов к построению интегрированных показателей, учитывающих значения нескольких первичных коли- чественных характеристик, систематизированных по следующим шести блокам:

- обучение и преподавание;

- студенты;

- исследования и разработки (ИиР);

- региональное взаимодействие;

- вовлеченность в обмен знаниями;

- международная деятельность.

Полный перечень использованных индикаторов приведен в табл. 2. По каждому из них вводится укрупненная порядковая шкала. Так, объем расходов на образование может быть высоким, средним, низким или очень низким; аналогичным образом строятся оценки по всем остальным характеристикам. Для сравнения вузов разработана оригинальная модель визуализации данных.

Предполагается, что основу классификации в ее финальной версии составят не исходные количественные, а преобразованные порядковые индикаторы с четырьмя упомянутыми выше возможными значениями. Как следствие, за счет перехода к порядковым величинам снизится влияние возможных ошибок в исходных данных и упростится интерпретация результатов.

\section{Великобритания}

В Великобритании традиционно применяются разные варианты классификации высших учебных заведений по возрасту и истории возникновения. В качестве примера приведем один из них [Scott, 1995]:

- Оксфорд и Кембридж;

- Университет Лондона;

- технологические вузы и бывшие технологические колледжи;

- новые университеты (бывшие политехнические);

- учебные заведения, основанные в викторианскую эпоху, на рубеже XIX и XX вв.(«redbricks») либо начатые с нуля в 60-е гг. XX в.

В Университете Манчестера попытались создать типологию вузов без привязки к истории их развития и другим априорным характеристикам [Howells et al., 2008]. Для этого была осуществлена кластеризация

Табл. 1. Индикаторы Европейской классификации вузов

\begin{tabular}{|c|c|}
\hline Категория & Индикаторы \\
\hline \multirow{4}{*}{$\begin{array}{l}\text { Образовательная } \\
\text { деятельность }\end{array}$} & Уровень образования \\
\hline & Разнообразие изучаемых курсов \\
\hline & Научная или практическая ориентация образовательных программ \\
\hline & Участие в европейских кооперационных программах \\
\hline \multirow[t]{5}{*}{ Научная деятельность } & Число публикаций в рецензируемых журналах в расчете на одного работника \\
\hline & $\begin{array}{l}\text { Интенсивность инновационной активности: число стартапов и патентов, доходы от контрактов } \\
\text { с бизнесом }\end{array}$ \\
\hline & Вовлеченность в европейские исследовательские программы \\
\hline & Ориентация на международный уровень научных исследований \\
\hline & Внедрение программ «обучения в течение всей жизни» \\
\hline \multirow{5}{*}{$\begin{array}{l}\text { Институциональные } \\
\text { характеристики }\end{array}$} & Размер: численность обучающихся и работников \\
\hline & Тип обучения: личное или дистанционное \\
\hline & Включенность в общественно-полезную деятельность \\
\hline & Удельный вес частных инвестиций в совокупном доходе \\
\hline & Форма собственности: частный/государственный \\
\hline
\end{tabular}




\section{Табл. 2. Индикаторы, предлагаемые Университетом Твенте для классификации вузов} в Европейском Союзе

\begin{tabular}{|l|}
\hline \multicolumn{1}{|c|}{ Индикатор } \\
\hline \\
\hline $\begin{array}{l}\text { Доминирующий уровень } \\
\text { присваиваемых степеней }\end{array}$ \\
\hline $\begin{array}{l}\text { Расходы на } \\
\text { образовательную } \\
\text { деятельность }\end{array}$ \\
\hline
\end{tabular}

Карьерная ориентация выпускников

Охват специальностей

Охват специальностей

Дистанционное обучение

Взрослые студенты

Вечернее обучение

Размер

Численность обладателей степени $\mathrm{PhD}$

Расходы на ИиР

Публикации в научных журналах

Другие рецензируемые материалы

Профессиональные

публикации

Региональные студенты

Выпускники, работающие в регионе

Привлечение источников финансирования в регионе

Культурные мероприятия

Доходы от обмена знаниями

Заявки на патенты

Стартапы

\section{Обучение и преподавание}

Вуз может фокусироваться на нескольких направлениях. Значение индикатора устанавливается с учетом превышения удельным весом выпускников, получивших соответствующую степень, в их общей численности экзогенно заданного порога (например, для степени бакалавра - более $40 \%$ )

Удельный вес расходов на образование в общем объеме расходов вуза (в том числе на учебные лаборатории, госпитали и т. п.). В некоторых случаях указываются суммарные расходы на ИиР и образование с оценкой доли образовательной составляющей в них

Все присваиваемые выпускникам степени делятся на три группы с позиции их дальнейшего трудоустройства. Первую составляют общеуниверситетские программы, не предполагающие овладения конкретной профессией. Вторая связана с обучением лицензируемым профессиям (врачи, адвокаты и т. п.). В третью группу попадают все остальные программы, нацеленные на освоение конкретных профессиональных навыков. Если к какой-либо категории относятся более трети выпускников, заведение получает соответствующую характеристику по карьерной ориентации

Число укрупненных областей наук, охваченных вузом. Группировка программ обучения производится по направлениям, предусмотренным классификацией образовательных программ ЮHЕСКО (ISCED'97)

\section{Студенты}

Удельный вес обучающихся дистанционно в общей их численности

Доля обучающихся в возрасте старше 30 лет по всем программам обучения в общей их численности

Удельный вес студентов, обучающихся на программах заочного или вечернего обучения (part-time), в общей их численности. В данном разделе не учитываются те, кто фактически обучаются дольше нормативно установленного срока

Общая численность студентов на всех программах обучения

\section{Исследования и разработки}

Численность лиц, получивших степень $\mathrm{PhD}$, в расчете на одного сотрудника (в пересчете на штатные единицы)

Удельный вес расходов на ИиР в объеме затрат вуза

Число публикаций в рецензируемых научных журналах в расчете на сотрудника (в пересчете на штатные единицы)

Число иных рецензируемых публикаций в расчете на сотрудника (книги, дизайнерские работы и др., прошедшие независимое рецензирование)

Число публикаций в нерецензируемых источниках, ориентированных на профессиональное сообщество, в расчете на сотрудника

\section{Региональное взаимодействие}

Удельный вес первокурсников, проживающих в регионе расположения вуза, в общей их численности

Доля выпускников, продолжающих в течение двух лет после окончания обучения работать в регионе расположения университета, в их общей численности

Удельный вес доходов, полученных от региональных и муниципальных властей, а также грантов и других поступлений, привлеченных от негосударственных организаций региона, в совокупном доходе

\section{Вовлеченность в обмен знаниями}

Число культурных мероприятий, организованных вузом, в расчете на 1000 работающих (в пересчете на штатные единицы)

Удельный вес частных заказов на проведение ИиР, обучение персонала, поступлений от патентов в совокупном доходе

Число поданных заявок на патенты, приходящихся на одного сотрудника (в пересчете на штатные единицы)

Среднее число созданных стартапов за последние три года в расчете на одного работника. Под стартапом понимается любая фирма, использующая результаты ИиР и знания данного вуза. Не имеют значения место расположения стартапа и его специализация (не обязательно технологические фирмы)

\section{Международная деятельность}

Иностранные студенты

Удельный вес студентов с дипломом, ранее полученным за рубежом, в общей численности обучающихся (участники программ обмена и двойных дипломов не учитываются)

Иностранное финансирование

Иностранные студенты по программам обмена

Иностранные

преподаватели

Студенты, уехавшие по обмену
Удельный вес зарубежных грантов и контрактов в совокупном доходе

Доля иностранных студентов, обучающихся по обмену, в общем приеме первокурсников

Удельный вес иностранных профессоров (иностранцы по национальности, приехавшие из других университетов) в общей численности сотрудников. Здесь, в отличие от большинства показателей, используется абсолютная численность персонала, без пересчета на штатные единицы

Отношение численности студентов, отправленных на международные программы обмена, к общей численности первокурсников 


\section{Табл. з. Переменные, использованные исследователями Университета Манчестера} для кластеризации вузов

\begin{tabular}{|c|c|}
\hline Описание переменной & Категория \\
\hline Темп роста общих поступлений & Размер \\
\hline Величина среднегодового дохода & Размер \\
\hline Темп роста дохода от ИиР & Исследования \\
\hline Удельный вес поступлений от ИиР в объеме совокупного дохода & Исследования \\
\hline Удельный вес доходов от интеллектуальной собственности в объеме совокупного дохода & Третья миссия \\
\hline Доля поступлений от консультационных услуг в объеме совокупного дохода & Третья миссия \\
\hline $\begin{array}{l}\text { Удельный вес первокурсников очных отделений из регионов с низкой долей лиц, } \\
\text { получающих высшее образование, в общей их численности }\end{array}$ & $\begin{array}{l}\text { Социальная деятельность } \\
\text { и доступность }\end{array}$ \\
\hline $\begin{array}{l}\text { Доля первокурсников очных отделений, закончивших государственные средние школы, } \\
\text { в их совокупной когорте }\end{array}$ & $\begin{array}{l}\text { Социальная деятельность } \\
\text { и доступность }\end{array}$ \\
\hline Соотношение численности заочных и очных аспирантов & $\begin{array}{l}\text { Обучение/ социальная } \\
\text { деятельность и доступность }\end{array}$ \\
\hline Удельный вес аспирантов в общем контингенте обучающихся & Обучение/исследования \\
\hline $\begin{array}{l}\text { Отношение числа защит } \mathrm{PhD} \text { к общему фонду оплаты труда профессорско- } \\
\text { преподавательского состава (ППС) и научных работников }\end{array}$ & Обучение/исследования \\
\hline Соотношение численности иностранных и британских студентов & Обучение \\
\hline Прирост численности студентов (в пересчете на очные) & Обучение \\
\hline
\end{tabular}

учебных заведений по уровням развития в следующих направлениях: образование, научная и инновационная деятельность, социальная поддержка, влияние. Использованные авторами переменные содержатся в табл. 3.

Анализ проводился методом k-средних. Выбор количества кластеров был осуществлен в ходе расчетов при числе кластеров в диапазоне от 2 до 20, с применением индекса Цалиньски-Харабаша [Caliński, Harabasz, 1974]. Последний рассчитывается как соотношение общего разброса объектов между кластерами и внутри их. Оптимальным считается число кластеров, при котором значение индекса максимально.

В указанном примере выбрано второе наилучшее разбиение, а именно на семь кластеров.

Метод кластеризации $\mathrm{k}$-средних представляет собой итерационную процедуру. На каждом этапе осуществляются перераспределение объектов кластеризации и пересчет числа кластеров. В первом случае каждый объект соотносится с ближайшем кластером по формуле:

$S_{i}^{(t)}=\left\{x: d\left(x, c_{i}^{(t)}\right) \leq d\left(x, c_{j}^{(t)}\right) \forall 1 \leq j \leq k\right\}$,

где: $S_{i}^{(t)}$ - объекты $i$-го кластера;

$c_{i}^{(t)}$ - центр $i$-го кластера;

$t$ - номер итерации.

Пересчет кластеров заключается в вычислении их новых центров, образовавшихся в результате перераспределения:

$$
c_{i}^{(t+1)}=\frac{1}{\left|S_{i}^{(t)}\right|} \sum_{x_{p} \in S_{i}^{(t)}} x_{p}
$$

Кластеризация прекращается, если после очередной итерации состав кластеров остается неизменным.

В результате были выделены семь кластеров (табл. 4).

В представленной типологии ключевую роль сыграли переменные, характеризующие динамику изменений в университетах за последние годы. Подобное

Табл. 4. Кластеры вузов в соответствии с типологией Университета Манчестера

\begin{tabular}{|c|c|}
\hline Наименование кластера & Общая характеристика \\
\hline $\begin{array}{l}\text { Вузы, ориентированные на } \\
\text { прикладные исследования }\end{array}$ & $\begin{array}{l}\text { Крупные университеты, отличающиеся высокой научной активностью и наличием } \\
\text { иностранных студентов, а также производством знаний и ориентацией на } \\
\text { прикладные исследования. Регулярно получают доход от объектов интеллектуальной } \\
\text { собственности }\end{array}$ \\
\hline Локально доступные вузы & $\begin{array}{l}\text { Имеют небольшой размер, среди обучающихся преобладают первокурсники, } \\
\text { выходцы из государственных школ и регионов с низкой долей лиц, получающих } \\
\text { высшее образование. Общий прирост доходов (как и их базовый уровень)—- } \\
\text { невысокий }\end{array}$ \\
\hline Исследовательская элита & $\begin{array}{l}\text { Крупные университеты, ориентированные на привлечение студентов из зарубежных } \\
\text { вузов и активно вовлеченные в научную деятельность }\end{array}$ \\
\hline «Специалисты для Лондона» & $\begin{array}{l}\text { Сосредоточены в Лондоне и пригородах. Похожи на первую группу. Отличаются } \\
\text { максимальным ростом доходов от ИиР, в меньшей степени нацелены на } \\
\text { производство знаний и создание объектов интеллектуальной собственности }\end{array}$ \\
\hline Активные «рекрутеры» студентов & $\begin{array}{l}\text { Несмотря на небольшие размеры, характеризуются максимальными значениями } \\
\text { прироста численности студентов и средним ростом общих доходов }\end{array}$ \\
\hline Уникальный открытый университет & Единственный большой вуз, ориентированный на обучение британцев \\
\hline
\end{tabular}


разделение на однородные группы имеет значение при разработке мер государственной политики в сфере высшего профессионального образования. Так, на этой основе выделяются вузы, ориентированные, прежде всего, на образовательную деятельность; выявляются места концентрации студентов, нуждающихся в социальном обеспечении. С точки зрения научной и инновационной активности на первый план выходят учебные заведения, предпочтительные для государственной поддержки.

\section{Филиппины}

Предложенная в этой стране типология [Bernardo, 2003] представляет интерес применительно к российскому образовательному рынку ввиду схожести ее целей и контекста создания. В ней, в частности, ставилась задача выявить организации, имеющие достаточный исследовательский потенциал. Заметим также, что структура сети образовательных учреждений на Филиппинах характеризуется существенной разнородностью; в ней представлены многочисленные узкоспециализированные заведения, например сельскохозяйственные колледжи, школы авиации и др.

Классификация охватила 220 вузов, действующих на территории Филиппин. Для каждого учебного заведения были собраны сведения по 45 показателям, отражающим те или иные стороны его деятельности. Приведем некоторые из них:

1) год основания;

2) число образовательных программ и их удельный вес по уровням (бакалавриат, магистратура, аспирантура, повышение квалификации и переподготовка) в общем числе программ;

3) численность и удельный вес поступивших на образовательные программы по указанным уровням обучения в суммарной когорте учащихся;

4) численность и удельный вес выпускников по уровням обучения в общей популяции закончивших обучение;

5) когорта штатных сотрудников ППС со степенью по категориям (PhD, магистр, бакалавр) и их общий контингент;

6) число публикаций сотрудников в международных, а также избранных филиппинских научных журналах (всего и в расчете на одного штатного работника).

Информация по большинству индикаторов из представленного выше списка (со 2-й по 4-ю группу) была получена из базы данных Агентства по образованию, в то время как параметры публикационной активности сотрудников рассчитывались с использованием международных и национальных баз публикаций В отношении филиппинских журналов учитывались публикации только в лучших из них (по субъективному выбору авторов исследования).

В кластерном анализе применялся иерархический метод, заключающийся в итерационном построении дерева объектов. На каждой итерации объединяются два ближайших друг к другу объекта либо ранее образованных кластера:

$$
K_{i j}^{(t)}=K_{i}^{(t-1)} \cup K_{j}^{(t-1)} \text {, если } d\left(K_{i}^{(t-1)}, K_{j}^{(t-1)}\right)=\min _{s, r} d\left(K_{s}^{(t-1)}, K_{r}^{(t-1)}\right)
$$

Для остальных кластеров выполняется равенство:

$$
K_{l}^{(t)}=K_{l}^{(t-1)}
$$

Процедура завершается, если при объединении кластеров образуется один, включающий все объекты. Вузы разделялись на группы в соответствии с деревом объектов на основе меры качества кластеризации.

В итоге образовались 12 кластеров, при этом три заведения были отнесены к категории уникальных, не подлежащих объединению с какими-либо другими. Выделенные кластеры были условно сгруппированы в три укрупненные группы (табл. 5).

Магистерские университеты представлены заведениями, ориентированными преимущественно на реализацию программ подготовки магистров. Значительная доля их сотрудников обладает учеными степенями. К категории «малых» относятся учреждения с небольшим контингентом учащихся и ППС, предлагающие ограниченный набор образовательных программ. Ни одно из них не имеет учитываемых в рамках данного исследования научных публикаций.

Таким образом, составленная филиппинскими специалистами классификация по трем крупным группам со сходными характеристиками базировалась, прежде всего, на размере учебных заведений и их ориентации в соответствии с уровнем образовательных программ.

Различия в вышеуказанных группах связаны с выбором программ обучения для абитуриентов и качеством ППС. Рассматриваемая кластеризация раскрыла лишь один срез филиппинской системы высшего образования, поскольку не охватывала вузы, ориентированные на разные целевые аудитории (например, аналоги федеральных и региональных российских университетов). Разделение образовательных учреждений по показателю качества научной деятельности во многом получилось дихотомическим в силу того, что для их оценки использовались достаточно строгие критерии (наличие публикаций в ведущих журналах).

\section{Основания для классификации вузов: российский подход}

Некоторые отечественные исследователи предлагают классифицировать высшие учебные заведения не только по формальным, но и по иным существенным признакам. Так, разработаны эмпирически обоснованные типологии, базирующиеся на стратегии адаптации (определяется по сочетаниям характеристик ресурсной обеспеченности и результативности) [Tumoßa, 2008] и экономической модели университета [Абанкина и др., 2010].

В табл. 6 описаны существующие подходы к типологизации российских вузов с соответствующими примерами. Они напрямую не выделяют типы заведений по сочетанию направлений активности (научной, образовательной, инновационной). Однако здесь учитываются диверсификация их доходов и непрофильные работы, что косвенно характеризует тип учреждения по комбинации основных сфер деятельности.

Представленный обзор позволяет сделать ряд выводов относительно классификации российских вузов с учетом их научного и инновационного потенциала: 


\begin{tabular}{|c|c|}
\hline Подгруппа & Описание \\
\hline \multicolumn{2}{|r|}{ Крупные университеты } \\
\hline 1 & $\begin{array}{l}\text { Включает два вуза, не отличающиеся большим разнообразием образовательных программ. В сравнении } \\
\text { с другими подгруппами характеризуется высоким удельным весом магистров в общей численности студентов } \\
\text { и одновременно низкой публикационной активностью персонала }\end{array}$ \\
\hline 2 & $\begin{array}{l}\text { Располагают широким ассортиментом образовательных программ, в основном на уровне бакалавриата } \\
\text { и дополнительного образования. Публикационная активность сотрудников выше, чем в предыдущей } \\
\text { подгруппе; у большинства из них имеются ученые степени }\end{array}$ \\
\hline 3 & $\begin{array}{l}\text { Практически не реализуют магистерские программы, учеными степенями обладают не более 3\% } \\
\text { преподавателей. Численность студентов максимальна }\end{array}$ \\
\hline 4 & $\begin{array}{l}\text { Категория похожа на предыдущую, однако в ней представлен более широкий набор образовательных } \\
\text { программ, наблюдается повышенный в сравнении с другими группами учебных заведений удельный вес } \\
\text { сотрудников с учеными степенями в общем контингенте ППС }\end{array}$ \\
\hline \multicolumn{2}{|r|}{ Магистерские университеты } \\
\hline 1 & $\begin{array}{l}\text { По сравнению с другими вузами своей категории имеют относительно небольшой размер и выбор } \\
\text { магистерских программ. ИиР ведутся в ограниченном объеме }\end{array}$ \\
\hline 2 & $\begin{array}{l}\text { Размер значительно крупнее, чем в предыдущем кластере. Удельный вес магистров и аспирантов в суммарной } \\
\text { численности учащихся значителен, в то же время уровень научных результатов предельно низкий }\end{array}$ \\
\hline 3 & $\begin{array}{l}\text { Характеризуются средним размером (между 1-й и 2-й подгруппами). Удельный вес магистерских программ } \\
\text { в общем числе реализуемых несколько ниже, чем в предыдущих группах, а аспирантских — примерно на том } \\
\text { же уровне }\end{array}$ \\
\hline 4 & $\begin{array}{l}\text { Небольшие заведения, имеющие более низкую, чем в других магистерских вузах, долю магистерских } \\
\text { и аспирантских курсов в общем числе программ. Удельный вес преподавателей с учеными степенями } \\
\text { в совокупной численности ППС также незначителен. В то же время данная подгруппа отличается } \\
\text { максимальными среди всех магистерских университетов научными результатами }\end{array}$ \\
\hline \multicolumn{2}{|r|}{ Малые вузы } \\
\hline 1 & $\begin{array}{l}\text { Предоставляют минимальный набор учебных программ, преимущественно бакалаврских; при этом } \\
\text { отличаются относительно высоким качеством ППС (около } 40 \% \text { сотрудников имеют ту или иную ученую } \\
\text { степень) }\end{array}$ \\
\hline 2 & $\begin{array}{l}\text { Характеризуются высоким удельным весом магистерских программ в общем числе и относительно низким } \\
\text { уровнем ППС (удельный вес сотрудников с ученой степенью не более 20\% от общей численности) }\end{array}$ \\
\hline 3 & $\begin{array}{l}\text { Подгруппа схожа с предыдущей, отличается чуть более высокими значениями совокупной популяции } \\
\text { сотрудников и доли обладателей ученых степеней в ней }\end{array}$ \\
\hline 4 & $\begin{array}{l}\text { При минимальном размере предлагают соответствующий спектр программ, исключительно бакалаврских. } \\
\text { Удельный вес обладателей ученых степеней в общей когорте ППС составляет в среднем около 30\% }\end{array}$ \\
\hline & 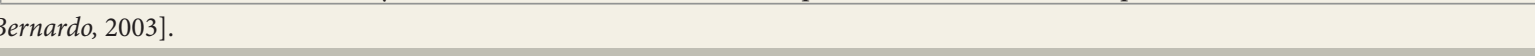 \\
\hline
\end{tabular}

- Наибольший интерес для исследователей и практиков в российском контексте представляют типологии, отражающие научную, образовательную и инновационную активность.

- Указанные аспекты могут отражаться через характеристики «продукта» и обеспеченности ресурсами. В этом случае оценивается способность учебного заведения к реализации определенных видов деятельности. Подобная типология выявляет многомерную картину разнообразия стратегий и их успешности. Потенциал может быть рассчитан, например, методом оболочечного анализа (Data Envelopment Analysis, DEA).

- Показатели, применяемые в различных классификациях, отчасти повторяются или являются похожими, благодаря чему без потери точности типологии можно пользоваться меньшим количеством индикаторов.

- В наиболее характерных примерах (Великобритании, России, Филиппин) группирование вузов по рассматриваемым параметрам произведено посредством кластеризации.

\section{Выбор показателей для кластеризации вузов}

Источником информации для разработки нашей типологии послужила база данных обследований научной и инновационной деятельности вузов и их кооперации с компаниями, реализованных ИСИЭЗ НИУ ВШЭ в рамках мониторинга экономики науки и охвативших 400 государственных вузов. Она дополнялась сведениями из открытых источников ${ }^{2}$. При этом в целях качественного анализа и получения надежных результатов оценивалась активность тех организаций, по которым имелись все значения индикаторов (всего 219). В остальных случаях присутствовали не менее двух пустых значений либо ошибки при вводе. Несмотря на сокращение списка, в нем осталось более половины учреждений, благодаря чему сохранилась приемлемая репрезентативность выборки.

Для отбора характеристик анализировалась корреляция между ними. Как показали расчеты, доля расходов на ИиР в общем объеме средств коррелирует с абсолютным значением объема внебюджетного финансирования этой деятельности на уровне 0.65 (значимо отлична от нуля), поэтому второй параметр не учитывался. Суммарный контингент и численность студентов в расчете на одного штатного преподавателя имеют положительную корреляцию (около 0.5). Второй индикатор был исключен по причине очевидных неточностей в указании состава штатных преподавателей некоторыми вузами. Наконец, число научных статей в расчете на одного сотрудника и когорта учащихся, приходящихся на одного преподавателя, имеют 
Табл. 6. Описание оснований для типологизации отечественных вузов

Краткое описание

Примеры
Основание для структуризации (классификатор)

По типу экономической модели

- «Бюджетники»

(преобладание бюджетного финан сирования, слабая диверсификация деятельности)

- «Продающие вузы»

(смешанное финансирование обра зовательной деятельности, низкая степень диверсификации)

- «Бюджетные диверсифицирован ные вузы» нансирования образовательной деятельности, высокая диверсификация)

- «Диверсификаторы»

(смешанное финансирование образовательной деятельности, высокая диверсификация)

- Негосударственные вузы (низкая диверсификация; не охвачены исследованием НИУ ВШЭ)

- Негосударственные вузы (высокая диверсификация; не охвачены исследованием НИУ ВШЭ)

По стратегии адаптации к изменениям внешней среды ${ }^{\star *}$ (доминирование бюджетного фи-

Тип экономической модели как характе ристика диверсификации деятельности и доходов вуза. Группировка опирается на сочетание показателей соотношения доходов от:

- образовательной и другой деятельности:

- бюджетного и внебюджетного финансирования образовательной деятельности

Поступления от образовательной деятельности в основном из средств бюджетов всех уровней, доля иной деятельности в общем объеме доходов несущественна

Доходы от образовательной деятельности получены в основном из внебюджетных источников, доля поступлений от иной деятельности в них пренебрежимо мала

Поступления от образовательной деятель ности обеспечиваются из средств бюджетов всех уровней, доля доходов от иной деятельности - существенна

Значительный удельный вес внебюджет ных источников в доходах от образовательной деятельности, доля поступлений от иной деятельности - существенна

Доходы в основном от образовательной деятельности

Поступления от образовательной и иной деятельности

Стратегия как характеристика управления и/или способа адаптации вуза к изменениям внешней среды. Определяется по сочетанию характеристик учреждения: уровня ресурсной обеспеченности образо вательного процесса, финансовой резуль тативности, непрофильной деятельности, количественному росту (за счет численности студентов и развития новых образо вательных программ)

• «Лидеры»
• «Диверсификаторы»
• «Экспансеры»
• «Аккумуляторы» (материально-
- «адровых и финансовых ресурсов)
• «Аусерваторы»
• «Нетипидеры»

Высокое значение базовых характеристик

Значительная непрофильная деятельность

Высокие показатели количественного роста (прием, открытие программ и т. п.)

Существенная ресурсная обеспеченность

Исключительно средние характеристики

Оценки ниже среднего

Выделение в определенную группу затруднительно
Санкт-Петербургский горный институт, Дагестанский, Челябинский и Калужский государственные педагогические университеты

Московский государственный строительный университет, Московская государственная юридическая академия

\section{МИСиС, МИФИ, МФТИ}

Белгородский государственный университет, Тюменский государственный нефтегазовый университет, Уральский государственный техничес кий университет

Академия Натальи Нестеровой, Московская финансово-юридическая академия

Российская экономическая школа, Московская высшая школа социальных и экономических наук

Названия вузов, относящихся к разным типам, по этическим соображениям в открытых источниках не приводятся. Ниже даются профили университетов, наиболее часто представляющих выделенные типы (по данным на 2005 г.).

Технические и технологические архитектурно-строительные и творческие вузы

Финансово-экономические и юридические университеты

Архитектурно-строительные и финансово-экономические вузы

Архитектурно-строительные и финансово-экономические вузы

Все типы с максимальным количеством классических и гуманитарнопедагогических вузов

Гуманитарно-педагогические и классические университеты

Все типы вузов

* Исследования, позволяющие классифицировать вузы по данному основанию, были проведены ИРО НИУ ВШЭ по вузам,

подведомственным Минобрнауки России [Абанкина и др., 2010]

** Серия исследований стратегии адаптации российских университетов была осуществлена научным коллективом НИУ ВШЭ [Титова, 2008].

Источник: составлено авторами.

положительную корреляцию 0.68. Предположительно, чем меньше общая численность преподавателей, тем больше статей приходится на каждого из них и слабее эффект «распыления» публикаций.

При расчете удельного показателя публикационной активности в качестве знаменателя использовалась общая численность профессорско-преподавательского состава и научных работников, включая внештатников.
В итоге кластеризация проводилась по пяти параметрам:

- «ЕГЭ» - средний балл ЕГЭ у студентов, зачисленных на первый курс в отчетном году;

- «Молодежь» - удельный вес молодых сотрудников (без ученой степени - до 30 лет, кандидаты наук - до 35 лет, доктора наук - до 40 лет) в общей когорте ППС; 
- «УБФ» - удельное бюджетное финансирование в отчетном году;

- «Размер» - суммарный контингент обучающихся (бюджетные и коммерческие места);

- «ИиР» - удельный вес средств на ИиР, полученных из внебюджетных источников, в общем объеме затрат на эту деятельность.

При выборе отмеченных параметров учитывались цели построения классификации (выделение групп вузов с примерно одинаковым потенциалом инновационного развития, ведения научной и образовательной деятельности), а также особенности имеющихся данных. Во-первых, чтобы исключить параметры с сильной статистически значимой связью, была проанализирована корреляция между ними. Во-вторых, некоторые показатели не принимались во внимание из-за многочисленных неточностей и выбросов в данных. Так, численность штатных сотрудников ППС нередко занижалась, вследствие чего все основанные на ней расчетные характеристики не рассматривались. Полученные кластеры отличаются друг от друга как минимум по одному индикатору.

Невзирая на небольшое количество параметров, кластеризация раскрывает потенциал высших учебных заведений в основных областях деятельности. Так, УБФ характеризует их образовательную и научную активность, поскольку учитывает все бюджетные расходы, в том числе на науку и образование. Параметр ЕГЭ отражает не только образовательные возможности вуза, но и перспективы вовлечения «качественных» студентов в ИиР. Удельный вес молодежи в общей когорте ППС среди кандидатов и докторов наук выявляет потенциал воспроизводства человеческого капитала и связанную с этим динамику развития вуза.

Об интенсивности инвестиций в прикладную науку можно судить по удельному весу внебюджетных средств в затратах на ИиР. Наконец, размер университета свидетельствует об экономической устойчивости, но вместе с тем может повлечь за собой снижение качества обучения и степени вовлеченности студентов в ИиР. Наличие талантливых студентов, сбалансированный состав преподавателей и солидные финансовые возможности дают дополнительное преимущество для развития научной деятельности.

\section{Метод исследования}

Расчеты проводились по методу иерархической кластеризации, предполагающей построение дерева на основе исходного множества объектов. Сначала в один кластер объединяется пара объектов, характеризуемая наименьшими различиями среди всех имеющихся (рис. 1).

На каждом следующем этапе итерации объединяются два ближайших друг к другу объекта либо ранее образованных кластера (в зависимости от того, где наблюдается меньшее значение метрики различия):

$$
K_{i j}^{(t)}=K_{i}^{(t-1)} \cup K_{j}^{(t-1)} \text {, если } d\left(K_{i}^{(t-1)}, K_{j}^{(t-1)}\right)=\min _{s, r} d\left(K_{s}^{(t-1)}, K_{r}^{(t-1)}\right)
$$

Для всех остальных кластеров никаких изменений не происходит:

$$
K_{l}^{(t)}=K_{l}^{(t-1)}
$$

Дальнейшие этапы построения иерархии выполняются до тех пор, пока все они не окажутся объединенными в один кластер. Результатом работы алгоритма выступает дерево (или иерархия кластеров). Преимуществом такого подхода по сравнению с методом k-средних, который был использован, например в [Howells et al., 2008], является не просто разбиение объектов на группы, но формирование иерархической структуры, позволяющей увидеть группы более и менее похожих объектов. Помимо собственно выделения кластеров, это дает дополнительную информацию о структуре анализируемой совокупности.

Кроме того, разбиение объектов на однородные группы в соответствии с методом k-средних зависит от выбранного начального положения центров кластеров. Поскольку объекты группируются относительно центров, можно получить различные варианты в зависимости от априорных предположений о структуре разбиения (начальных положений центров кластеров).

Следует указать, что нами рассматривались методы кластеризации, ориентированные на анализ количественных характеристик изучаемых объектов. Существует также большое количество методов, предназначенных для работы с дихотомическими переменными (наличие/отсутствие признака). Возможность и целесообразность преобразования характеристик исследуемых вузов к дихотомическому виду и проведения кластеризации с таким новым представлением объектов - вопрос последующих исследований.

В основе тех или иных модификаций иерархического подхода лежат разные способы расчета расстояния, отделяющего два изолированных объекта либо кластер от объекта. От них зависит результат кластеризации, поэтому выбор расчетного метода должен производиться с особой тщательностью. В качестве метрики различия между отдельными объектами использовалось евклидово расстояние в пятимерном пространстве, определяемое по формуле (7). Данные по каждой переменной были предварительно преобразованы в шкалу 0-100. Подобный подход к нормализации (использование размаха значений признака для нормализации) является одним из наиболее предпочтительных [Миркин, 2011].

$$
d\left(o_{1}, o_{2}\right)=\sqrt{\sum_{i=1}^{5}\left(x_{1, i}-x_{2, i}\right)^{2}}
$$

Евклидово расстояние в нашем случае оказалось наиболее надежной и обоснованной метрикой. Она

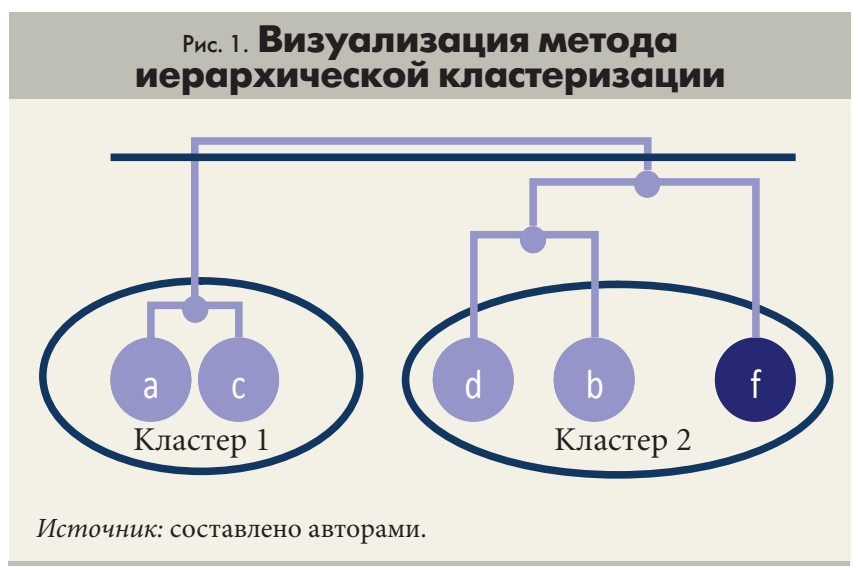


позволяет «не замечать» небольшие различия между объектами и в то же время сильно «штрафовать» за существенное различие хотя бы по одному из признаков. В представленном исследовании предполагалось, что вузы внутри одного кластера должны быть, насколько это возможно, однородны по всем отобранным показателям. Именно по этой причине было выбрано евклидово расстояние, а не метрика, учитывающая только крайнее (наибольшее или наименьшее) расхождение между объектами по всем характеристикам.

Ключевой характеристикой кластера (промежуточ ного в дереве и окончательного при анализе разбиения объектов) является внутренний разброс точек. В данном случае в качестве меры разброса служила сумма расстояний от объектов до центра кластера (формула 8):

$$
\delta(c l)=\sum_{o_{i} \in c l} d\left(o_{j}, \operatorname{center}(c l)\right)
$$

При выборе меры разброса учитываются особенности изучаемых данных. Такая мера разброса, как расстояние от центроида до наиболее удаленного объекта, которая в ином случае могла бы обеспечить более однородное разбиение, оказалась в нашем случае ненадежной, поскольку слишком чувствительна к выбросам в данных.

В связи с этим для подсчета различий между кластером, объектом либо двумя кластерами применялся метод Варда [Ward, 1963]. Тогда расстоянием между двумя кластерами считается прирост суммы расстояний от всех группируемых объектов к центру объединенного кластера по сравнению с суммой расстояний от объектов до центров по отдельности в каждом кластере. Другими словами, измеряется ухудшение внутрикластерного разброса, которое произойдет в случае объединения двух кластеров:

$$
\gamma(c l)=\delta\left(c l_{1+2}\right)-\delta\left(c l_{1}\right)-\delta\left(c l_{2}\right)
$$

Для объединения выбирается пара кластеров с наименьшим расхождением в вышеуказанном смысле. Кроме того, особенностью использования метода Варда является склонность к получению кластеров сопоставимого размера, так как при прочих равных в этом случае происходит присоединение маленьких кластеров к большим. В нашем исследовании указанная особенность привела к более надежным и устойчивым результатам - возможности выявить различные типы вузов вместо получения неоднородного разбиения с выделением узких групп «уникальных» объектов.

Таким образом, применение метода Варда позволяет создать кластеризацию, характеризующуюся небольшим разбросом объектов внутри полученных кластеров. «Продуктом» кластеризации является иерархия групп объектов (иногда называемая таксономией). В связи с этим метод обеспечивает не только разбиение выборки на группы, но и отслеживание структуры данных. После построения таксономии дерево «отсекается» на некотором расстоянии. Все группы, расстояния между которыми меньше выбранного порогового значения, считаются объединенными (в соответствии с ветвями дерева). Нами была проанализирована группировка вузов при различных способах отсечения дерева. С учетом анализа значимости различий между кластерами и их структуры было выбрано отсечение, образующее разбиение на 6 кластеров. Описание такого разбиения приводится в следующем разделе.

\section{Характеристика типологии вузов}

В табл. 7 представлены количественные параметры центров каждого из кластеров, а также число попавших в них объектов. Более темным цветом выделены кластеры, имеющие значение по показателю значимо выше среднего. Более светлым цветом обозначены те из них, которые характеризуются значениями соответствующих индикаторов на уровне существенно ниже среднего.

Из табл. 7 видно, что по уровню среднего балла ЕГЭ поступивших абитуриентов кластеры можно разделить на две группы. Вузы из кластеров 1, 3 и 5 показывают статистически значимо более низкие результаты, чем вузы из кластеров 2, 4 и 6. Между кластерами внутри каждой из групп различия незначимы.

По доле молодых сотрудников в общей численности ППС кластеры (с учетом значимости различий) выстроены следующим образом. Наименьшее ее значение наблюдается в вузах кластера 3 - в среднем около 6\%. Затем идут кластеры 2, 4 и 6 с примерно одинаковым значением этого показателя - на уровне $15 \%$. Следующим по порядку кластером является пятый (21\%). Наибольшая доля молодежи среди ППС (24\%) выявлена в кластере 1 .

По удельному бюджетному финансированию заметно выделяется кластер 4, в остальных кластерах вузы относительно однородны.

Самые крупные по размеру вузы попали в кластеры 2 и 6 (значимо больше остальных), средние отнесены к кластерам 4 и 5, а малые (с численностью студентов около 5000 чел.) вошли в кластеры 1 и 3.

По удельному весу внебюджетных средств в общем объеме затрат на ИиР выделяются вузы из кластеров 1 и 2. В них ИиР практически полностью финансируются из внебюджетных источников. Другую крайность представляют вузы из кластера 6, где в среднем лишь $13 \%$ финансирования ИиР приходится на внебюджетные средства. Другие три кластера (3, 4 и 5) занимают промежуточную позицию. Для последних этот показатель значимо ниже, чем у вузов из кластеров 1 и 2, и значимо выше тех, что относятся к кластеру 6.

Анализ показывает, что каждый кластер характеризует такая совокупность индикаторов, которая значимым образом отличает относимые к нему вузы от остальных учебных заведений в рассматриваемой

\begin{tabular}{|c|c|c|c|c|c|c|}
\hline \multicolumn{7}{|c|}{$\begin{array}{c}\text { Табл. 7. Профили кластеров } \\
\text { и распределение объектов }\end{array}$} \\
\hline $\begin{array}{l}\text { Номер } \\
\text { кластера }\end{array}$ & «ЕГЭ» & $\begin{array}{l}\text { «Моло- } \\
\text { дежь» }\end{array}$ & «УБФ» & «Размер» & «ИиР» & $\begin{array}{l}\text { Количе- } \\
\text { ство } \\
\text { объектов }\end{array}$ \\
\hline 1 & 59.81 & 0.24 & 82.75 & 5905.31 & 89.82 & 36 \\
\hline 2 & 66.32 & 0.15 & 90.05 & 13495.43 & 86.92 & 37 \\
\hline 3 & 57.42 & 0.06 & 95.82 & 5825.06 & 71.61 & 32 \\
\hline 4 & 70.77 & 0.16 & 205.40 & 7947.39 & 70.72 & 18 \\
\hline 5 & 59.53 & 0.21 & 85.15 & 7177.98 & 50.80 & 42 \\
\hline 6 & 65.00 & 0.15 & 101.54 & 9005.85 & 13.41 & 54 \\
\hline
\end{tabular}
выборке. Поскольку кластеризация не обеспечива- 
ет «чистого» деления на типы, так как кластеры всегда пересекаются в проекциях на оси показателей, в целях упрощения было создано дерево классификации как инструмент для причисления вуза к той либо иной группе (рис. 2). Оно задает систему показателей, сравнение с которыми реальных характеристик конкретного университета дает основание отнести его к определенной категории.

Все сказанное позволило вычленить пять типов университетов, распределенных по шести кластерам:

«Нишевые вузы» (кластеры 1 и 3). Небольшие вузы с численностью студентов от 3 до 7.5 тыс., принимают абитуриентов с низким уровнем ЕГЭ - до 63 баллов; наука поддерживается в основном из внебюджетных источников. Кластер отличается высоким удельным весом молодых преподавателей в общей когорте ППС и низким значением УБФ - от 60 до 90 тыс. руб. Научные возможности этих учреждений ограничены ввиду их закрепления в территориально-локальных нишах с лимитированными ресурсами для развития и перспективами увеличения государственного финансирования на фоне избыточной зависимости от своих основных потребителей. Половину «участников» составляют педагогические и классические, до одной трети - технические (бывшие технологические) университеты.

«Вузы неопределенной позиции» (кластер 5). В целом, эти образовательные учреждения похожи на «нишевые». К ним относятся малые и средние вузы (до 10 тыс. студентов), отличающиеся невысоким качеством приема, значительной долей молодых сотрудников ППС, недостаточным финансированием ИиР из бюджетных и внебюджетных источников (приблизительно) в равных долях и низким уровнем УБФ. Вероятно, их ожидает снижение набора и трансформация в «нишевые». Исследовательский потенциал (по ресурсной оценке) - незначителен.

«Маркет-лидерами» (кластер 2) можно назвать крупные вузы, принимающие преимущественно студентов с высокими баллами ЕГЭ. Наука в них поддерживается главным образом из внебюджетных источников. Эти вузы ведут активный маркетинг образовательных услуг, получая соответствующие выгоды. Как показывает практика, такие вузы способны при определенных усилиях концентрировать ресурсы на некоторых направлениях ИиР и инновационных проектах, добиваясь серьезных результатов. Основную сложность представляет интеграция образования с наукой по причине высокой численности студентов и поточных технологий обучения. Стимулировать научную деятельность в этом случае могла бы внутренняя квазивенчурная поддержка исследовательских коллективов и отдельных ученых с целью постепенного формирования крупных проектов со смешанными механизмами финансирования. Подобный тип образовательных учреждений представлен прежде всего классическими и социально-экономическими университетами.

«Потенциальные и реальные научно-образовательные лидеры» (кластер 4). Отличаются предельно высоким бюджетным финансированием в расчете на одного студента - свыше 157 тыс. руб.; высоким средним баллом ЕГЭ абитуриентов - 70 баллов; наивысшим научным потенциалом. Располагая мощной ресурсной базой, они имеют возможность (но не обязательно ее используют) развивать науку и интегрировать ее с образованием. Одним из направлений их развития могут стать программы по стимулированию взаимодействия с мировыми исследовательскими центрами и вхождение в международные научные проекты. Более половины учебных заведений данного типа - технические.

«Вузы на хорошем счету» (кластер 6) имеют средний либо крупный размер и характеризуются высококачественным приемом. Бюджетное финансирование в среднем по кластеру несколько выше, чем в других группах, однако по этому показателю его состав неоднороден. Данный кластер отличается практически полным отсутствием поддержки науки из внебюджетных источников. Сюда включены главным образом классические и технические университеты. Некоторые из них имеют давнюю историю и бренды. Они на хорошем счету у потребителей и государства, обладают определенным исследовательским заделом, базирующимся

Рис. 2. Дерево классификации

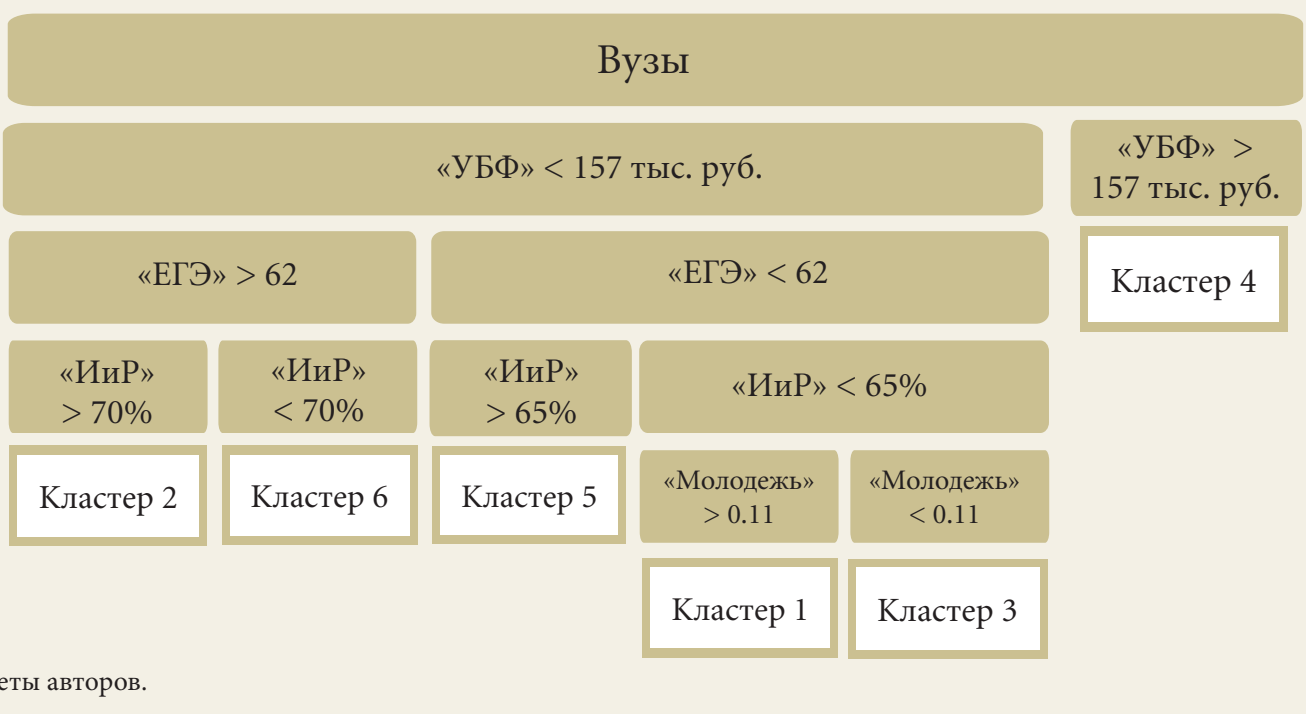


на старых научных школах, связях и квалифицированных кадрах. Последний, однако, может ослабнуть из-за условной «стабильности», что отразится на способности вузов взаимодействовать с внешними заказчиками и партнерами.

Теперь снова вернемся к распределению исследованных вузов по кластерам (табл. 7). В категории «нишевых вузов» и «вузов неопределенной позиции» попадает почти половина рассмотренных вузов, что вполне наглядно свидетельствует о состоянии научного потенциала существенной части системы высшего образования страны ${ }^{3}$. Категория «потенциальных и реальных научно-образовательных лидеров» охватывает менее 10\% исследованных вузов. Это - вузы, обладающие ресурсным потенциалом, способствующим их научной деятельности, но не гарантирующим ее результаты. Реальных лидеров среди них может оказаться еще меньше.

К оставшимся двум типам - «маркет-лидерам» и «вузам на хорошем счету»- относятся около $40 \%$ вузов, вошедших в нашу выборку. Пообъектный анализ свидетельствует, что эти вузы в основном сфокусированы на образовательной деятельности, хотя и обладают определенным (в некоторых случаях - значительным) научным потенциалом. В любом случае, вузы данных типов способны удовлетворять потребности ключевых стейкхолдеров и имеют перспективы дальнейшего развития.

Получить представление о распределении классических, педагогических и т. п. вузов в полученной типологии можно с помощью диаграммы, приведенной на рис. 3. На ней не представлены архитектурные и гуманитарные вузы в силу их малочисленности в исследуемой выборке образовательных учреждений. Сумма долей вузов каждого типа по всем кластерам дает 100\%. Полученное распределение вполне соответствует ожиданиям экспертов, что подтверждает состоятельность предложенной типологии:

- Подавляющая часть педагогических вузов (примерно 70\%) входят в группы «нишевых вузов» и «вузов неопределенного типа».
- Значительная часть социально-экономических вузов (около 65\%) представлена вузами таких типов, как «маркет-лидеры» и «вузы на хорошем счету», при этом они в наибольшей степени распространены среди «маркет-лидеров».

- Почти 50\% технических вузов (как и, в целом, около половины всех вузов) попадают в группы «нишевых вузов» и «вузов неопределенной позиции», причем технические вузы относительно лучше других представлены среди «потенциальных научнообразовательных лидеров» (примерно 15\%).

В табл. 8 показано сопоставление полученной типологии с наиболее близкими по составу решаемых задач классификациями. Исходя из этого, можно сформулировать следующие выводы:

- Для разработки типологии применялись оценки ресурсной обеспеченности и результативности, в той или иной степени пересекающиеся с индикаторами зарубежных аналогов и характеризующие вузы в различных аспектах их деятельности.

- Предложенная классификация близка к типологии британских университетов [Howells et al., 2008] как с точки зрения постановки задачи и используемых параметров, так и описанных типов.

- Указанные факторы дают основание считать полученные результаты в высокой степени достоверными.

- При применении показателей, характеризующих динамику соответствующих явлений, вероятно, выявились бы дополнительные подтипы в уже определенных категориях. Это не поменяло бы картину в целом, но позволило бы при накоплении рядов данных сделать принципиальные выводы о направлениях развития высших учебных заведений. Ввиду отсутствия динамических индикаторов в использованной нами базе данных, проверить указанное предположение пока не представляется возможным, однако их целесообразно учесть в дальнейших исследованиях.

Полученная посредством кластеризации типология вузов обладает определенным недостатком, харак-

\section{Рис. з. Распределение вузов различных типов по кластерам (\%)}

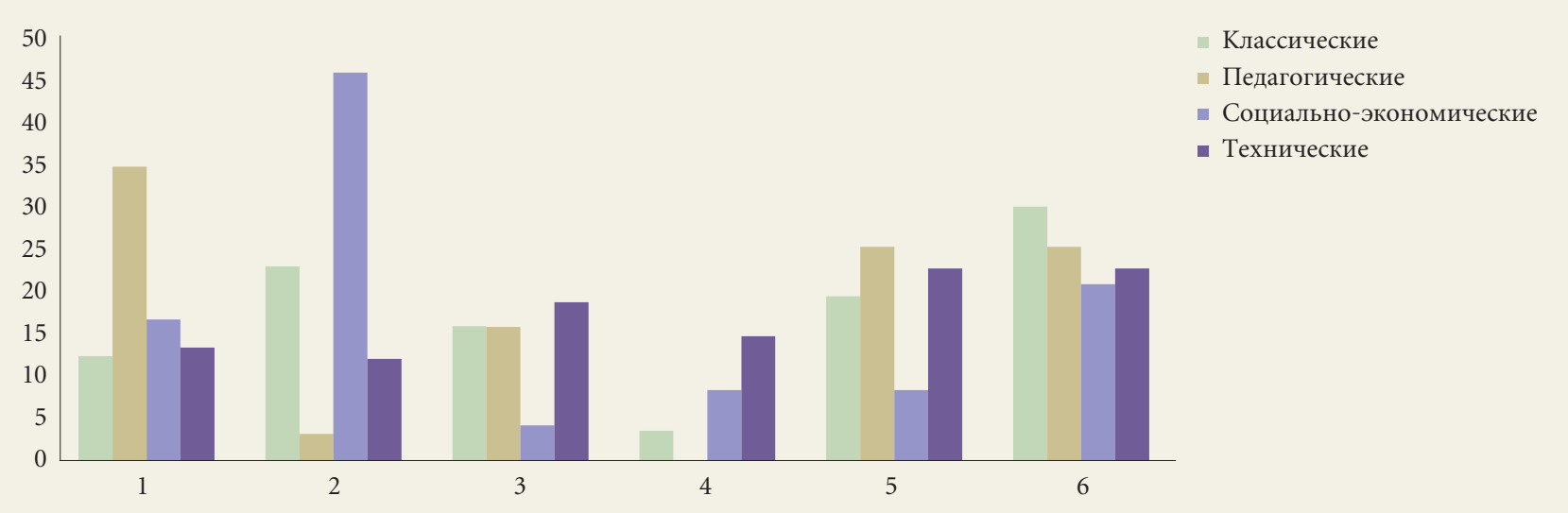

Источник: расчеты авторов.

3 Здесь следует еще раз оговориться, что речь идет о ресурсном обеспечении научной деятельности вузов. 


\section{Табл. 8. Сравнение предложенной авторами типологии с другими} рассмотренными выне классификациями

\begin{tabular}{|c|c|c|}
\hline Типология & $\begin{array}{l}\text { Выделенные в типологии } \\
\text { кластеры }\end{array}$ & Сравнение с предложенной авторами типологией \\
\hline $\begin{array}{l}\text { Британская типология, осно- } \\
\text { ванная на динамических } \\
\text { и структурных показателях ис- } \\
\text { следовательской, образователь- } \\
\text { ной, а также консультационной } \\
\text { деятельности вузов (14 показа- } \\
\text { телей) [Howells et al., 2008] }\end{array}$ & $\begin{array}{l}\text { - Ориентированные на при- } \\
\text { кладные исследования } \\
\text { • Локально доступные вузы } \\
\text { • Исследовательская элита } \\
\text { - «Специалисты для Лон- } \\
\text { дона» } \\
\text { - Активные «рекрутеры» сту- } \\
\text { дентов } \\
\text { - Ориентированные на ИиР } \\
\text { и активно набирающие сту- } \\
\text { дентов } \\
\text { Уникальный открытый } \\
\text { университет }\end{array}$ & $\begin{array}{l}\text { Данная типология из всех рассмотренных наиболее } \\
\text { близка к поставленной в нашей работе задаче. } \\
\text { Ее основное отличие от предлагаемой нами состоит } \\
\text { в использовании показателей, отражающих динамику } \\
\text { численности студентов, доходов от различных видов } \\
\text { деятельности и т. п. Набор индикаторов, если исключить } \\
\text { динамические, схож с использованным в разработанной } \\
\text { нами типологии. } \\
\text { Применение динамических характеристик позволило } \\
\text { выделить большее количество градаций в рамках услов- } \\
\text { ных типажей «исследовательских», «обучающих» и вузов } \\
\text { «третьей миссии», чем в предложенной нами типологии. } \\
\text { Увеличенное число выделенных кластеров также может } \\
\text { быть связано с объективно большей дифференциацией } \\
\text { британских университетов по причине сильной и дли- } \\
\text { тельной конкуренции между ними }\end{array}$ \\
\hline $\begin{array}{l}\text { Филиппинская типология, } \\
\text { базирующаяся на показателях } \\
\text { размера вузов, структуры обра- } \\
\text { зовательных программ по уров- } \\
\text { ням, качества ППП и т. п. } \\
\text { (45 показателей) [Bernardo, } \\
2003 \text { ] }\end{array}$ & $\begin{array}{l}\text { Всего } 12 \text { кластеров, разбитых } \\
\text { на три группы вузов: } \\
\text { - крупные } \\
\text { - магистерские } \\
\text { - малые }\end{array}$ & $\begin{array}{l}\text { Разрабатывалась для решения аналогичной задачи (фор- } \\
\text { мулирование избирательных политик по отношению } \\
\text { к тем или иным учебным заведениям) и имеет внешнее } \\
\text { сходство с предложенной нами классификацией, а имен- } \\
\text { но выделяет маркет-лидеров и научных лидеров. } \\
\text { Базовое отличие состоит в фокусировке на показателях, } \\
\text { характеризующих способность вузов качественно } \\
\text { обучать студентов, включая устойчивость. Такие харак- } \\
\text { теристики научной активности, как публикации в цити- } \\
\text { руемых изданиях, оказались низкочувствительными } \\
\text { к различиям между филиппинскими университетами }\end{array}$ \\
\hline $\begin{array}{l}\text { Типология российских вузов } \\
\text { (подведомственных Минобр- } \\
\text { науки России) на основе эко- } \\
\text { номической модели. Деление } \\
\text { проводится по сочетанию по- } \\
\text { казателей соотношения доходов } \\
\text { от образовательной и другой } \\
\text { активности, вклада бюджетного } \\
\text { и внебюджетного финансирова- } \\
\text { ния в образовательную деятель- } \\
\text { ность [Абанкина } и \text { др., 2010] }\end{array}$ & $\begin{array}{l}\text { • «Бюджетники» } \\
\text { • «Продающие» } \\
\text { - «Бюджетные диверсифици- } \\
\text { рованные вузы» } \\
\text { - «Диверсификаторы» }\end{array}$ & $\begin{array}{l}\text { Применялась при анализе политики государственной } \\
\text { поддержки высшего образования на примере вузов, } \\
\text { участвовавших в эксперименте ГИФО. Базируется на } \\
\text { показателях финансирования образовательной деятель- } \\
\text { ности. Соответственно типология отличается от предло- } \\
\text { женной не только основанием для выделения типов } \\
\text { (по экономической модели), но и привязкой типологии } \\
\text { к образовательной активности. Другие типы учитыва- } \\
\text { ются как уровень диверсификации. Основное сходство } \\
\text { типологий заключается в использовании параметров } \\
\text { ресурсной обеспеченности }\end{array}$ \\
\hline
\end{tabular}

Источник: составлено авторами.

терным для выбранного метода. Ввиду «размытости» каждого из кластеров в пространстве векторов, отражающих ресурсный задел, в них могут входить организации, различия между которыми по этому параметру достигают степени, не позволяющей напрямую сравнивать объекты из одного кластера. В работе [Абанкина и др., 2013] для корректного сравнения вузов одного типа использовался классический непараметрический инструмент изучения относительной их продуктивности по выборке - метод оболочечного анализа (DEA) с постоянной отдачей от масштаба. С его помощью в последующем оценивалась научно-образовательная результативность относительно потенциала технических и классических университетов как наиболее представительных по размеру подвыборок. При анализе потенциала входными параметрами служили удельные характеристики бюджетного финансирования, наличия обладателей ученых степеней в общей численности ППС, а также средний балл ЕГЭ первокурсников. В качестве выходных учитывались такие переменные, как суммарный контингент, взвешенный удельный вес молодых сотрудников в общей когорте ППС и научных работников (по возрастным категориям), публикационная активность (число научных статей в рецензируемых журналах в расчете на 100 чел. $)^{4}$.

На рис. 4 представлены диаграммы распределения вузов внутри кластеров 1-5 по интервалам балла технической эффективности как базы для корректной оценки научно-образовательной результативности университетов.

Наложив подобную оценку на кластеры российских вузов, можно сделать определенные обобщения:

- Большая группа вузов (кластеры $1,3,5)$ имеет не только ограниченный ресурсный потенциал для научной деятельности, но и низкие оценки результативности, полученные по методу DEA. Особенно 
«Маркет-лидеры» (кластер 2)

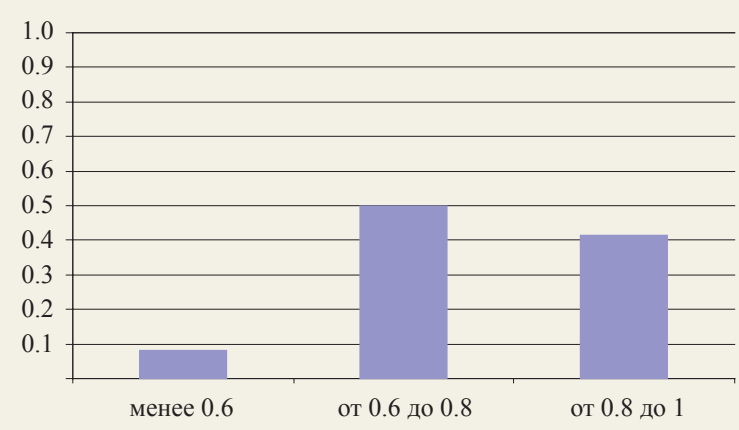

«Нишевые вузы» (кластеры 1 и 3)

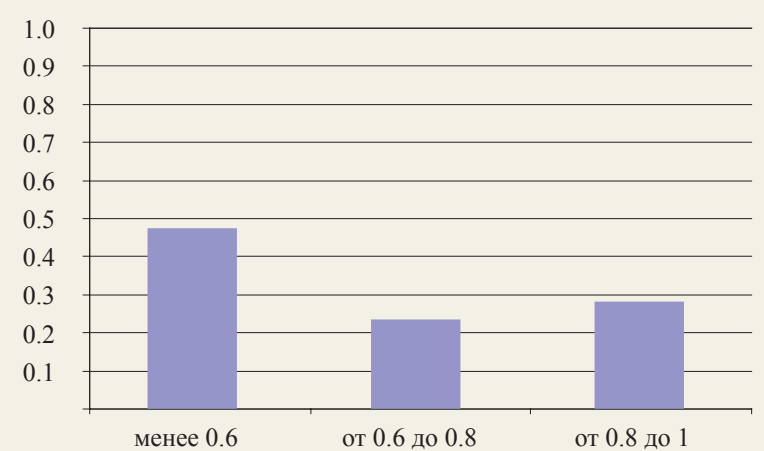

«Потенциальные и реальные научнообразовательные лидеры» (кластер 4)

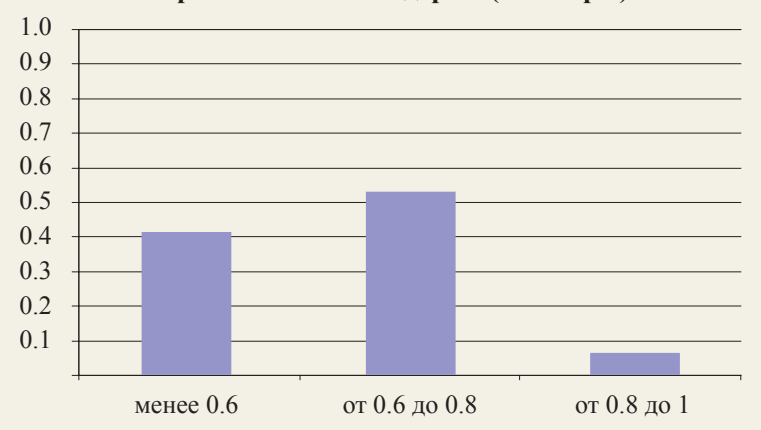

«Вузы неопределенной позиции» (кластер 5)

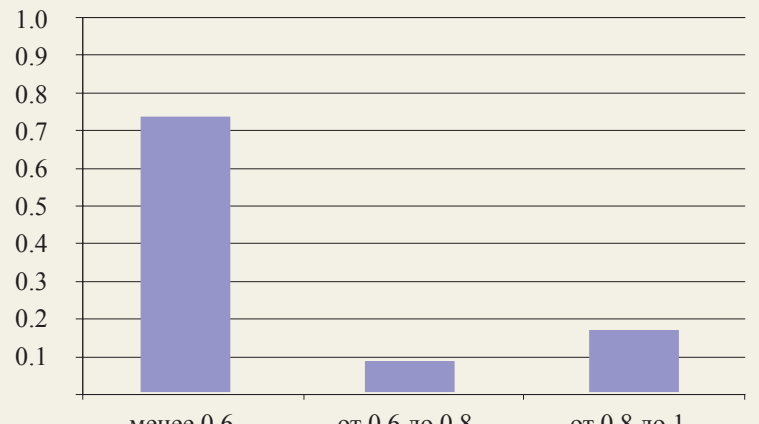

* Кластер 6 на диаграммах не представлен из-за недостатка данных для оценки методом DEA.

Источник: расчеты авторов.

ярко это видно на примере кластера 5 («вузы неопределенной позиции»), что скорее подтверждает сделанное ранее предположение о возможном «сжатии» вузов такого типа до размеров «нишевых». В данном случае имеет место принципиальное ограничение исследовательского потенциала и результативности вузов теми ресурсными нишами, в которых они находятся.

- Вузы, принадлежащие к классу «маркет-лидеров» (кластер 2), в среднем демонстрируют существенно более высокие показатели результативности, оцененные по методу DEA, чем вузы других типов. Более $40 \%$ вузов этой категории можно отнести к высокоэффективным (показатель технической эффективности — от 0.8 до 1), а свыше 90\% к средне- и высокоэффективным (показатель технической эффективности - от 0.6 до 1). Это означает, что «маркет-лидеры» получают высокую отдачу от имеющихся ресурсов, могут более качественно их использовать по сравнению с вузами других типов, способны ставить цели и добиваться результатов.

- В отношении вузов - «потенциальных и реальных научно-образовательных лидеров» были получены несколько неожиданные результаты. Свыше 40\% таких вузов отличаются низкими показателями эффективности, и менее 10\% из них можно отнести к высокоэффективным.
Объяснение этому кроется в спецификации использованной модели DEA. В работе были проверены модели с разными входными и выходными показателями, и оказалось, что именно фактор публикационной активности как выходной показатель существенно влияет на оценку производительности университетов, причем и технических, и классических. Публикационная активность меняет распределение оценок эффективности: без ее учета получается «красивая» гистограмма с нарастанием по мере увеличения продуктивности и некоторым снижением числа вузов на границе производительности, а с учетом - отмечается хорошо видимое разделение вузов на группы по результативности. Пообъектный анализ показывает, что ряду вузов публикационная активность позволяет приблизиться к порогу эффективности; на некоторые другие это не очень влияет, а есть такие, которые несут существенные потери в оценке эффективности при включении подобного фактора в анализ. В силу сказанного при расчете технической эффективности целесообразно предусмотреть корректировки для тех вузов, для которых существуют барьеры к открытым публикациям, если это дает значимое (и неоправданное) снижение оценки их производительности. В то же время для тех низкоэффективных вузов, 
относящихся к рассматриваемой группе, для которых нет публикационных барьеров, отмеченное обстоятельство может быть обусловлено реально существующим избыточным ресурсным потенциалом при одновременно скромных выходных показателях. Иными словами, на основе полученных результатов можно выявить чрезмерное инвестирование в некоторые вузы. Возможно, указанный эффект не будет наблюдаться на более длительном временном интервале.

\section{Заключение}

Анализ существующих типологий выявил, что наибольший интерес представляют те из них, которые отражают различные аспекты функционирования университетов. Это касается их научной, образовательной и инновационной активности, которая может быть охарактеризована индикаторами не только результатов, но и ресурсной обеспеченности.

В последнем случае фиксируется тип потенциала учреждения, его способность к реализации определенных видов деятельности. Подобная типология, дополненная оценками степени реализации ресурсной базы (например, с помощью методов оболочечного анализа), обеспечивает многомерную картину разнообразия стратегий вузов и их успешности. Те или иные их классификации опираются в известной мере на схожие показатели, что дает основание для выделения и применения сокращенного - универсального - набора характеристик без снижения ее точности.

В наиболее показательных зарубежных кейсах группирование образовательных учреждений осуществлялось посредством кластеризации, использованной и в нашей работе. С помощью иерархического метода, расчетов метрик дифференциации и объединения кластеров на основе метода Варда были выделены и описаны шесть кластеров. Созданная типология включает дерево решений для отнесения организации к тому или иному типу и содержит детальную характеристику каждой категории.

Обработка эмпирических данных по российским государственным вузам дала возможность выделить среди них несколько типов, в том числе: «Нишевые вузы», «Вузы неопределенной позиции», «Маркет-лидеры», «Потенциальные и реальные научно-образовательные лидеры», «Вузы на хорошем счету».

С помощью полученной типологии можно проанализировать разнородную совокупность отечественных вузов и выработать адресные меры политики по каждой из выделенных групп. Дополненная оценкой результативности по методу DEA, она позволяет прояснить ситуацию в том или ином кластере и сформировать ожидания относительно каждого учреждения. Предложенный подход к созданию типологии и оценке научного потенциала высших учебных заведений, генерируя нетривиальные результаты, обеспечивает доказательную базу для формирования целенаправленной политики развития высшего образования.

Рассмотренная нами типология университетов учитывает различные направления их деятельности и не является аналогом рейтингов либо распространенных в литературе иных оценок эффективности. Совершенствование системы сбора информации о деятельности вузов и повышение качества данных будут способствовать дальнейшему развитию исследований в этом направлении.

Абанкина И.В., Абанкина Т.В., Николаенко Е.А., Сероштан Э.С., Филатова Л. (2010) Экономическое положение вузов в условиях бюджетной реформы, повышения автономии и введения ЕГЭ. М.: ГУ-ВШЭ.

Абанкина И.В., Алескеров Ф.Т., Белоусова В.Ю., Зиньковский К.В., Петрущенко В.В. (2013) Оценка результативности университетов с помощью оболочечного анализа данных // Вопросы образования. № 2. С. 5-38.

Миркин Б.Г. (2011) Методы кластер-анализа для поддержки принятия решений: обзор. Препринт WP7/2011/03. М.: НИУ ВШЭ.

Титова Н.Л. (ред.) (2008) Стратегии развития российских вузов: ответы на новые вызовы. М.: МАКС Пресс.

Abankina I., Aleskerov F., Belousova V., Bonch-Osmolovskaya A., Petruschenko V., Ogorodniychuk D., Yakuba V., Zinkovsky K. (2012) University efficiency evaluation with using its reputational component // Proceedings of the 4th International Conference on Applied Operational Research. Bangkok: Tadbir Operational Research Group. P. 244-253.

Bartelse J., van Vught F. (2007) Institutional Profiles: Towards a Typology of Higher Education Institutions // IAU Horizons. Vol. 13. № 2-3. P. 9-11.

Bernardo A.B.I. (2003) Towards a Typology of Philippine Higher Education Institutions. Manila: Commission on Higher Education.

Calinski R., Harabasz J. (1974) A dendrite method for cluster analysis // Communications in Statistics. № 3. P. 1-27.

Howells J., Ramlogan R., Cheng S-L. (2008) The Role, Context and Typology of Universities and Higher Education Institutions in Innovation Systems: A UK Perspective. MIoIR Discussion Paper. Manchester: University of Manchester.

McCormick C., Zhao C. (2005) Rethinking and Reframing the Carnegie Classification // Change (September-October). P. 51-57. Режим доступа: http://classifications.carnegiefoundation.org/downloads/rethinking.pdf, дата обращения 18.05.2013.

Scott P. (1995) The Meanings of Mass Higher Education. Buckingham: Open University Press.

University of Twente (2005) Institutional Profiles Towards a Typology of Higher Education Institutions in Europe. Режим доступа: http://www.utwente.nl/mb/cheps/research/projects/ceihe/publications/socratesceiheinstitutionalprofiles.pdf, дата обращения 29.04.2013.

Ward J.H., Jr. (1963) Hierarchical Grouping to Optimize an Objective Function // Journal of the American Statistical Association. Vol. 58. P. 236-244. 


\title{
Typology and Analysis of Russian Universities' Performance in Education and Science Perspectives
}

\author{
Irina Abankina \\ Director, Institute for Educational Studies. E-mail: abankinai@hse.ru
}

Fuad Aleskerov

Head, Department of Mathematics, Faculty of Economics, and Head, International Laboratory of Decision Choice and Analysis. E-mail: alesk@hse.ru

\section{Veronika Belousova}

Head, Department for Methodology of Budget Planning, Institute for Statistical Studies and Economics of Knowledge. E-mail: vbelousova@hse.ru

\section{Leonid Gokhberg}

Director, Institute for Statistical Studies and Economics of Knowledge, and First Vice-Rector. E-mail: lgokhberg@hse.ru

\section{Kirill Zinkovsky}

Deputy Director, Institute for Educational Studies. E-mail: kzinkovsky@hse.ru

\author{
Sofya Kiselgof \\ Lecturer, Department of Mathematics, Faculty of Economics. E-mail: skiselgof@hse.ru
}

Sergey Shvydun

Research Assistant, International Laboratory of Decision Choice and Analysis. E-mail: shvydun@hse.ru

National Research University - Higher School of Economics

Address: National Research University Higher School of Economics, 20, Myasnitskaya str., Moscow, 101000, Russian Federation

\begin{abstract}
$\mathrm{O}$ ver the past decades due to increasing economic pressure and rising demands by government and society, the organizational landscape of higher education is changing while university activities become more diversified. The focus of public support is shifting from funding current activities of universities towards rewarding outcomes. There are, as a result, many strategies to adapt and develop universities in this changing environment. For example, emerging typologies for structuring a network of higher education institutions (HEIs) taking into account their diversity are at the forefront in many countries of agendas for greater efficiency in higher education. We advance a typology for HEIs in Russia taking into

account indicators of research and teaching activities. We present an overview of best practices for HEIs, some typologies, a set of indicators and mathematical tools for constructing a typology of Russian public HEIs. This typology is based on clustering the input (resource allocation) and output (performance) indicators that characterize academic and educational achievements of HEIs. The proposed classification differentiates types of universities and contains a decision tree that allows assigning universities to one category or another. It can be used as a basis for a comprehensive analysis of diverse Russian universities and for government policies to address each of the identified HEI types, depending on their characteristics.
\end{abstract}

\section{Keywords}

higher education institutions (HEIs); typology; research and education activities of HEIs; hierarchical clustering

\section{References}

Abankina I., Abankina T., Nikolaenko E., Seroshtan E., Filatova L. (2010) Ekonomicheskoe polozhenie vuzov v usloviyakh byudzhetnoi reformy, povysheniya avtonomii i vvedeniya EGE [The economic situation in universities in terms of budget reform, improving the autonomy and the introduction of the USE], Moscow: HSE.

Abankina I., Aleskerov F., Belousova V., Bonch-Osmolovskaya A., Petruschenko V., Ogorodniychuk D., Yakuba V., Zinkovsky K. (2012) University efficiency evaluation with using its reputational component. Proceedings of the 4th International Conference on Applied Operational Research, Bangkok: Tadbir Operational Research Group. P. 244-253.

Abankina I., Aleskerov F., Belousova V., Zinkovsky K., Petruschenko V. (2013) Otsenka rezul'tativnosti universitetov s pomoshch'yu obolochechnogo analiza dannykh [Evaluating the university performance by the means of the shell data analysis]. Voprosy Obrazovaniya [Journal of Educational Studies], no 2, pp. 5-38.

Bartelse J., van Vught F. (2007) Institutional Profiles: Towards a Typology of Higher Education Institutions. IAU Horizons, vol. 13, no 2-3, pp. 9-11.

Bernardo A.B.I. (2003) Towards a Typology of Philippine Higher Education Institutions, Manila: Commission on Higher Education.

Calinski R., Harabasz J. (1974) A dendrite method for cluster analysis. Communications in Statistics, no 3, pp. 1-27.

Howells J., Ramlogan R., Cheng S-L. (2008) The Role, Context and Typology of Universities and Higher Education Institutions in Innovation Systems: A UK Perspective (MIoIR Discussion Paper), Manchester: University of Manchester.

McCormick C., Zhao C. (2005) Rethinking and Reframing the Carnegie Classification. Change (September-October), pp. 51-57. Available at: http://classifications.carnegiefoundation.org/downloads/rethinking.pdf (accessed 18.05.2013.

Mirkin B. (2011) Metody klaster-analiza dlya podderzhki prinyatiya reshenii: obzor [Cluster Analysis for Decision Making: Review]. Working Paper WP7/2011/03, Moscow: HSE.

Scott P. (1995) The Meanings of Mass Higher Education. Buckingham: Open University Press.

Titova N. (ed.) (2008) Strategii razvitiya rossiiskikh vuzov: otvety na novye vyzovy [Development Strategies of Russian Universities: Responses to the New Challenges], Moscow: MAKS Press.

University of Twente (2005) Institutional Profiles Towards a Typology of Higher Education Institutions in Europe. Available at: http://www.utwente.nl/ $\mathrm{mb} / \mathrm{cheps} /$ research/projects/ceihe/publications/socratesceiheinstitutionalprofiles.pdf, accessed 29.04.2013.

Ward J.H., Jr. (1963) Hierarchical Grouping to Optimize an Objective Function. Journal of the American Statistical Association, vol. 58, pp. 236-244. 


\section{Концептуальные основы и эффекты Форсайт-исследований: классификация и практическое применение}

\section{М. Бассей'}

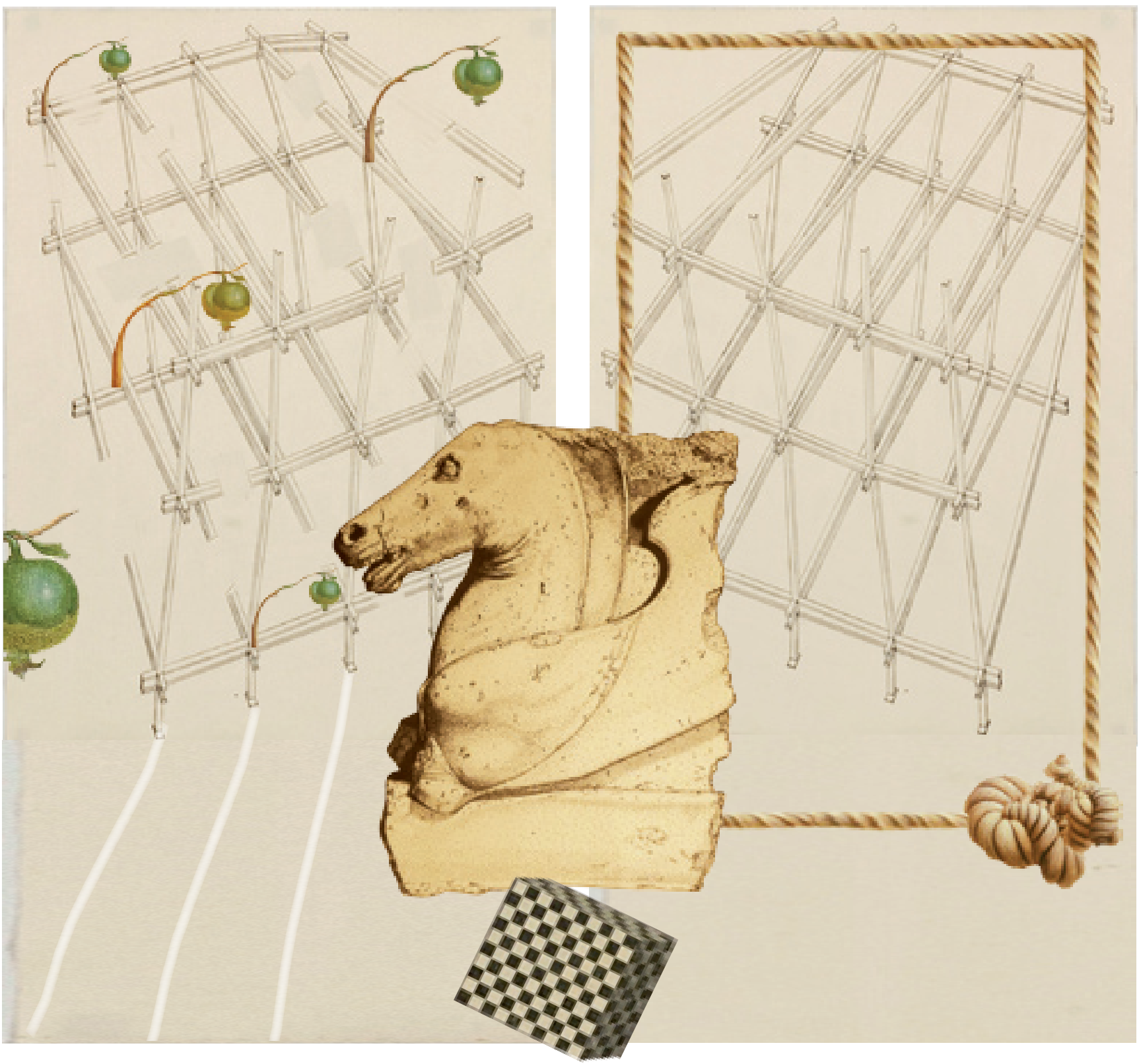

Стратегии будущего, как правило, исходят из двух подходов, опирающихся на разные принципы. Одни, нацеленные на жесткие шаблоны, создают ограниченное представление о зарождающемся контексте и не способны к адекватному реагированию на перемены. Другие не привязаны к шаблонам, позволяют опознавать скрытые возможности, извлекать широкий спектр преимуществ и достигать поставленных целей.

В статье анализируются указанные подходы, раскрывается зависимость качества стратегий от доминирующих паттернов, которых придерживаются их разработчики.

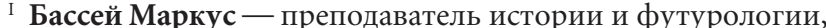
факультет искусств и бизнеса; научный сотрудник, Центр исследований устойчивого развития, Университет Sunshine Coast (University of the Sunshine Coast), Австралия. E-mail: MBussey@usc.edu.au

Адрес: University of the Sunshine Coast, Locked Bag 4, Maroochydore DC, Queensland, 4558 Australia

\section{Ключевые слова}

концепции; эффекты; шаблоны; моделирование; «открытые» и «закрытые» стратегии будущего; причинно-следственные связи; практика Форсайт-исследований 
K онцепции оказывают влияние на исследования будущего, которое проявляется, оценивается и регулируется в ходе практической деятельности. В связи с этим, вызывает интерес взаимодействие между теорией и практикой, посредством которого осуществляются коммуникация, обучение и апробация концепций в Форсайт-проектах. Осознание концептуальных рамок позволяет модифицировать этот процесс и вооружить специалистов надежными инструментами. Изучение концепций следует на чать с основополагающих принципов. Они дают возможность структурно проанализировать не отъемлемые элементы Форсайта, которые, хотя часто и не заметны, создают условия для конструирования и тестирования концепций, а также для оценки оказываемых ими эффектов.

\section{Ключевые принципы}

Фундаментальный принцип Форсайта исходит из установки, что представления о будущем руководят нашими текущими действиями [Slaughter, Bussey, 2005]. Тем самым настоящее соотносится с концептуальным пространством будущего, что акцентирует внимание на несуществующем контексте, побуждает выйти за рамки сиюминутных интересов и способствует в итоге формированию расширенного представления о перспективах раз вития. Таким образом, видение будущего может стимулировать выработку стратегий и плана превентивных мер. Рассматриваемые далее ключевые принципы служат ориентирами в изучении буду щего, структурируют теорию и практику Форсайт исследований, генерируют движущие силы для культурных и социальных преобразований.

Так, при исследовании будущего целесообразно руководствоваться набором следующих принципов [Slaughter, Bussey, 2005]:

- предопределенность текущих решений представляемой картиной будущего;

- фокусировка на поиске предпочтительных сценариев, оценке возможностей расширения потенциала человека и его самореализации;

- учет «открытых»и «закрытых» стратегий;

- неограниченность во времени, вариативность (поскольку причинно-следственные связи нелинейны), ориентация на процесс и моделирование вариантов, а не следование шаблонам;

- применение практического воображения, поиск альтернатив и разрушение стереотипов, идентификация взаимосвязей и анализ их логики;

- развитие навыков выработки превентивных мер. Приведенный перечень принципов органично дополняется высказыванием Д. Дейтора: «Любая конструктивная идея, относящаяся к будущему, вначале выглядит абсурдной» [Dator, 2002]. Понятия «нелепое»и «абсурдное» — весьма важные, необходимые категории в анализе образов будущего. Парадоксально, но именно они могут оказаться ключом к пониманию сложности и «сочетанию несочетаемого».

Мы живем в «эпоху пробуждения» [Korten, 2006; Macy, 2007], когда темы самоосмысления и размышления о будущем не считаются привилегией только отдельных кругов, а становятся доступными для широких слоев общества [Hawken, 2007; Parkin, 2010]. С технической точки зрения это обусловлено распространением открытых систем, характеризующих процесс глобализации, a c концептуальной - прагматизмом Форсайтисследований.

\section{Прагматизм}

Практика Форсайт-исследований опирается на достаточно простые концепции, которые тем не менее являются действенными инструментами, поскольку позволяют вырабатывать конкретные понятия, предоставляют основу для методик [Inayatullah, 2008a,b], задают направление, цели и этические ориентиры деятельности ${ }^{1}$. В этом смысле Форсайту присущ прагматизм не только из-за его нормативной ориентации, но и потому, что мышление и решения субъекта относятся к высокому уровню сложности. При поиске правильных ответов проблемы рассматриваются в общем контексте интересов [Brandom, 2008, c. 12]. Это способствует раскрепощению мышления и дает возможность опираться на разные точки зрения - от ранних прагматиков (У. Джеймса ${ }^{2}$, Д. Дьюи [Dewey, 1997] и Ч. Пирса [Peirce, 2001]) до постструктуралистов (Ж. Делеза и Ф. Гуаттари [Deleuze, Guattari, 1987]). Первые считают прагматизм формой исследования кругозора как поля действий, вторые придерживаются мнения, что концепции производят эффекты в соответствующей среде.

В своей профессиональной деятельности автор исходит из нижеперечисленных концепций:

- геофилософия (geophilosophy);

- «корневище» (rhizome);

- межцивилизационный диалог (intercivilisational dialogue);

- гетеротопия (heterotopia);

- неотьемлемое свойство (immanence);

- гибридность (hybridity);

- будущее (future);

- причинно-следственные связи (causality);

- моделирование (patterning);

- «открытые»и «закрытые» стратегии будущего (open and closed futures);

- культура (culture);

- практическое воображение (practical imagination);

- предвосхищение (anticipation).

Первые шесть концепций детально описаны в нашей более ранней работе [Bussey, 2009b]. Мы же сфокусируемся на остальных, при осмыслении

\footnotetext{
Ниже представлен авторский терминологический аппарат, находящийся на стадии формирования.

См. например [James, 1896, p. 124]: «Можно утверждать, что если два различных описания реальности имеют идентичные последствия, то и сами они идентичны, а отличия между ними иллюзорны и заключаются лишь в выражающих их многословных формулировках».
} 


\section{Табл. 1. Ключевые концепции Форсайт-исследований и лежацие в их основе принципы}

\begin{tabular}{|c|c|c|}
\hline Концепция & Область применения & Основополагающие принципы \\
\hline Будущее & $\begin{array}{l}\text { Характер } \\
\text { представлений } \\
\text { о будущем }\end{array}$ & $\begin{array}{l}\text { - Изменив представление о будущем, мы прибегнем к иным действиям } \\
\text { - По-разному интерпретируя будущее, мы расширяем спектр возможных } \\
\text { стратегий } \\
\text { - Наличие веера стратегий будущего повышает устойчивость к внешним } \\
\text { воздействиям }\end{array}$ \\
\hline $\begin{array}{l}\text { Причинно- } \\
\text { следственные } \\
\text { связи }\end{array}$ & $\begin{array}{l}\text { Зоны } \\
\text { ответственности } \\
\text { субъекта за свои } \\
\text { действия }\end{array}$ & $\begin{array}{l}\text { - Линейные представления о причинно-следственных связях позволяют видеть } \\
\text { причины перемен только «вовне» } \\
\text { - Нелинейное мышление расширяет потенциал стейкхолдеров, осознающих себя } \\
\text { причинным центром ситуации } \\
\text { - Линейные представления о причинно-следственных связях порождают } \\
\text { «закрытые» стратегии, нелинейные - «открытые» }\end{array}$ \\
\hline Моделирование & $\begin{array}{l}\text { Оценка контекста } \\
\text { деятельности }\end{array}$ & $\begin{array}{l}\text { - Отношение к реальности как к многообразию моделей расширяет потенциал } \\
\text { стейкхолдеров } \\
\text { - Осознание роли мыслительных клише позволяет переосмыслить } \\
\text { привязанность к доминантным нормам и создать альтернативы } \\
\text { - Представление формирования моделей в виде трехстадийного процесса } \\
\text { иллюстрирует эволюцию и дает основу «многослойной» концепции } \\
\text { реальности, согласно которой в тот или иной момент времени доминирует } \\
\text { определенная стадия. Осознается изменчивость идентичности, которая } \\
\text { временами фиксируется благодаря поддерживающим ее условиям }\end{array}$ \\
\hline $\begin{array}{l}\text { «Открытые» } \\
\text { и «закрытые» } \\
\text { стратегии }\end{array}$ & $\begin{array}{l}\text { Характер поведения } \\
\text { в отношении } \\
\text { будущего }\end{array}$ & $\begin{array}{l}\text { - Ощущение угрозы существованию идентичности «загоняет» в «закрытые» } \\
\text { стратегии } \\
\text { - Укрепление идентичности стимулирует к открытости и восприятию } \\
\text { деятельности как «моделирования отношений» (relational patterning) } \\
\text { • «Закрытые» стратегии ослабляют общественную и личную устойчивость, } \\
\text { «открытые» - усиливают }\end{array}$ \\
\hline
\end{tabular}

Источник: составлено автором.

которых можно понять ключевые принципы, лежащие в их основе. Некоторые из них систематизированы в табл. 1 .

\section{Будущее}

Позволяя анализировать возможные сценарии будущего, эта концепция способствует правильному пониманию того, как действовать сегодня, иными словами - служит информационной основой для текущих моделей поведения. Как известно, прошлое и будущее влияют на настоящее через убеждения, ценности и ожидания [Bussey et al., 2012b]. Посредством Форсайта познаются сложившаяся и зарождающаяся реальность, влияние предположений о будущем на сиюминутные решения, политику, устремления, опасения, а также поддерживающие их отношения и когнитивные ловушки. Будущее является своеобразным виртуальным полигоном для «обучения возможностям» (pedagogies of possibility) [Bussey et al., 2012a]. Представляя собой пространство широких возможностей, оно характеризуется многогранностью и контекстуальным разнообразием [Bussey et al., 2012b], «объектами для обучения» (nested pedagogical sites). В этом многообразии помогает сориентироваться многослойная причинная педагогика (causal layered pedagogy, CLP) [Bussey, 2009a], отводящая «ученику» роль «творца» собственного положения.

\section{Причинно-следственные связи}

Такие связи следует рассматривать не как линейный драйвер, а скорее как организующий центр, вокруг которого кластеризуются действия и эффекты. Они представляют собой сложную сеть, в которой причина и следствие находятся в контекстуальной зависимости.

Многослойный причинный анализ (causal layered analysis, CLA), как и CLP, не фокусируется на том или ином каузальном уровне проблемы, а рассматривает их в комплексе, предлагая соответствующие шаги [Inayatullah, 2004] $]^{3}$. Осознание степени зависимости будущего от сегодняшних шагов мотивирует к интенсификации влияния. В этом случае присутствует элементарная логика поскольку стейкхолдеры конструируют реальность своей активностью либо бездействием, они могут преобразовать ее, всего лишь изменив модель поведения. Следовательно, действия, несмотря на обстоятельства, всегда находятся в зависимости от позиций актора. Отношение к причинноследственным связям как к линейному фактору сужает представления о будущем, ставит предпринимаемые меры в зависимость от заданных условий, ограничивая воображение. Осознание многослойности связей и их «неочевидности» в любом контексте позволяет оценить исходное положение и начать конструировать более содержательные и реалистичные образы будущего. Иными словами, линейное мышление рождает «закрытые» стратегии будущего, а нелинейное - «открытые», на которых мы подробнее остановимся ниже.

\section{Моделирование}

Пример гуманитарной сферы (в частности, поведение знаменитостей) наглядно демонстрирует,

Подробнее о многослойном причинном анализе см. также статьи М. Энтони, опубликованные в предыдущих номерах журнала «Форсайт», — «Рубежи теории интеллекта» (2007, № 4, с. 4-18) и «Глубинные исследования будущего: выход за рамки монетарно-технократической парадигмы» (2012, № 4, с. 60-70). Прим. ред. 
что человек создает шаблоны [Bussey, 2008]. Так, Дж. Кемпбелл [Campbell, 2008] и У. Томпсон [Thompson, 2004] отмечают «мифический» характер такого процесса, который Дж. Делез и Ф. Гуаттари [Deleuze, Guattari, 1987] наделили метафорой «корневища» (rhizome), а Р. Калассо [Calasso, 1993] описал его проявление в социальных и культурных аспектах. В свою очередь, С. Пинкер [Pinker, 2011] и Дж. Лакофф [Lakoff, 2005] продемонстрировали, как шаблоны влияют на решения посредством мемов и метафор. Паттерны и смысловые содержания являются влиятельными социокультурными мемами и эффективным инструментом упорядочивания; интуиция в их отношении имеет генетическую природу [Wells, 2010]. Более того, создание моделей оказывает кумулятивный эффект, поскольку через подражание развивается так называемое «коллективное обучение» (collective learning), способствующее распространению шаблонов [Christian, 2004]. Следовательно, общество и культура эволюционируют в тандеме. Развитие паттернов происходит в три этапа, рассматриваемых далее. Их можно сравнить с уровнями анализа, охватываемыми такими методами Форсайта, как «ландшафт будущего» (futures landscape) [Inayatullah, 2007] ${ }^{4}$ и многослойный причинный анализ [Inayatullah, 2004].

1. Предмодель (pre-pattern) соответствует стадии «джунглей» (по концепции «ландшафта будущего») или «констатации факта» (litany) (согласно методам CLA/CLP). Характеризуется состоянием хаоса и спонтанным потоком событий. Определенность, смысловое наполнение, а значит и управление - отсутствуют. Действия предпринимаются без четких ориентиров. Опыт обретается методом проб и ошибок. Эффект подобного состояния постоянные внутренние противоречия между ощущением свободы и ожиданием негативных последствий.

2. Шаблон (pattern) упорядочивает среду, порождает определенную культуру, укрепляет идентичность на уровне личности и коллектива. При этом теряется «свобода», взамен которой обретаются устойчивость и предсказуемость. В Форсайте этот этап соответствует разработке «стратегии и видения» (strategy and vision) («ландшафт будущего») и выходу на системно-мировоззренческий уровень (CLA/ CLP). Мировоззрение, поддерживаемое соот ветствующими знаниями и аргументацией, обеспечивает порядок в обществе. Подобные признаки присущи сценарной модели «дисциплинированного общества» (disciplined society) [Dator, 2002].

3. Моделирование (patterning) предполагает баланс между свободой и безопасностью, которые здесь не рассматриваются как абсолюты. Приоритет отдается дискуссиям с участием стейкхолдеров и специалистов по Форсайту, представляющих разные культуры. Благодаря культурному многообразию удается избежать застоя и закрытости. Подобные черты присущи «креативному решению» («ландшафт будущего»), рождающемуся в ходе совместного обучения (participatory learning), и «мифо-метафорическому уровню» (CLA/ CLP). В результате формируются альтернативы доминантным моделям, что расширяет потенциал участников.

Указанный трехстадийный процесс, как следует из описания, носит «эволюционный» характер. На протяжении тысячелетий череда экспериментов и инновационных прорывов привела человечество к выходу на «острие развития» (growing edge) [Gershon, 2009]. Прогресс не всегда давался легко, так как ввиду распространения специализации и нарастания сложности появлялось все больше шаблонов, перекрывавших альтернативы. Тем не менее, он продолжается, и люди все сильнее осознают, что способны генерировать перемены и создавать шаблоны. Сдвиг в сторону «дисциплинированных» вариантов будущего отметил С. Уэллс: «Успешная культурная адаптация, как правило, имеет обратную сторону. Формирование сельскохозяйственного уклада жизни, повлекшего за собой увеличение плотности населения, потребовало ограничения личных потребностей в пользу интересов массовой культуры. В результате мы оказались “в клетке”, как в плане географии, так и видов деятельности» [Wells, 2010, p. 113]. Кроме того, он рассматривает «перекрестное опыление» и инновации как признаки культуры и драйверы перехода от «закрытого» к «открытому» будущему. Осознание того, что Форсайт-исследования эффективный инструмент поиска новых моделей, обусловливает повышенный интерес к рассматриваемой сфере.

\section{«Открытые» и «закрытые» стратегии будущего}

Подобного рода бинарная концепция описывает степень открытости к принятию альтернатив, ведущих к разным вариантам будущего. Специалисты по Форсайту могут помочь заинтересованным сторонам перейти от «закрытой» стратегии к «открытой», снабдив их инструментами для управления турбулентностью и неопределенностью, возникающими в результате такого перехода. Как отмечают эксперты компании Shell [BV, 2008], вначале «путешествующие» проникаются энтузиазмом, который впоследствии сменяется дезориентацией, однако возрождается, когда сценарии начинают реализовываться. Эмоциональные перепады могут привести к стрессовым состояниям, по мере того как процесс набирает ход.

Участие в дискуссиях, учитывающих различные точки зрения, не стремящиеся к консенсусу, позволяет приобрести уникальный опыт.

Метод исследований будущего, изначально разработанный Х. Тиббсом и расширенный С. Инаятуллой. «Ландшафт» понимается как набор четырех фиксированных состояний восприятия и действия: «джунгли», «стратегия», «видение» и «креативное решение». В последней из перечисленных стадий программа действий переходит с индивидуального уровня на общественный. 
Здесь ввиду кажущегося отсутствия четких целей и здравого смысла могут возникнуть сомнения в реализуемости сценариев [BV, 2008, p. 51].

«Закрытые» стратегии, соответствующие терминам Инаятуллы, — «привычное» (used futures), «дезавуированное» (disowned futures) либо «инерционное» (business-as-usual futures) будущее, 一 по определению привязаны к доминантной модели. Приверженные конкретному набору атрибутов, они соблюдают те или иные интересы, ценности и нормы, стремясь воспрепятствовать реализации вероятных событий, выходящих за стандартные рамки. Тем самым поддерживается идентичность, благодаря которой субъект находит свое место в мире, а ее дестабилизация оказывается для него серьезным потрясением. Это объясняет, почему многие руководители готовы рисковать завтрашним днем ради текущей стабильности.

«Открытые» стратегии, в свою очередь, предполагают всеохватность и коллективизм. Они отличаются устойчивой идентичностью, восприимчивостью к сложной природе бытия, «многоголосью» каждого контекста [Stone and Stone, 1989; Ferruci, 2004], едва уловимым внутренним состояниям и альтернативным способам извлечения знаний [Bussey, 2010]. Открытость к альтернативным вариантам будущего несет в себе как возможности, так и риски. Способность управлять неопределенностью и инновациями приводит к трансформационным эффектам. Оценка сравнительной «закрытости/открытости»служит основой для идентификации факторов, стимулирующих либо сдерживающих переход от «закрытых» стратегий к «открытым». Уверенность и неуверенность коренятся в социальных установках. Во времена социальной нестабильности идентичность отличается закрытостью. В благополучные периоды ей присущи открытость, инклюзивность, стремление развивать отношения. Этим объясняется, к примеру, изменчивость политических предпочтений. Как будет показано далее, выявив степень «открытости» либо «закрытости» стратегий, можно идентифицировать «блоки», «разрывы»и «друзей» будущего.

\section{Культура}

Исследователи будущего могут содействовать стейкхолдерам в идентификации тех факторов, которые препятствуют трансформационным процессам, искажают их либо стимулируют.

Определенное влияние оказывает и культура, поскольку ограничивает свободу отдельных субъектов, что относится как к обществу в целом, так и к отдельным социальным группам и индивидам. Культура представляет собой огромный пласт накопленных знаний, имеющих исторические, контекстуальные и эпистемологические корни на уровне власти и иерархий идентичности [Foucault, 2005; Derrida, 2002]. Она способна менять представления о реальности, ограничивать потенциал воображения и порабощать. Форсайт обнаруживает факт подобного влияния и его последствия.
Здесь следует учитывать три аспекта. Вопервых, имеются культурные «сюжеты» (отчасти отраженные в вышеприведенной цитате Уэллса). Культура представляет собой продукт создания шаблонов. На протяжении тысячелетий сформировались многочисленные паттерны, гибридные и глобализированные современные культуры. Моделирование будущего - живой, динамичный процесс, тогда как шаблон диктует закрытость и обслуживание специфических интересов, «це ментирует» идентичность, придает своим адептам ощущение безопасности и жестко пресекает попытки выйти за рамки укорененной модели. Это так называемая «культура первого типа», нацеленная на укрепление идентичности и безопасности в условиях «джунглей» (предмодельной стадии), угрожающих порядку, стабильности и существованию общества.

Второй тип культуры характеризуется способностью адаптироваться и развиваться в соответствии с новыми условиями [Wells, 2010, p. 111]. По мнению П. Саркара, он опирается на постоянное стремление к расширению границ познания. В художественной литературе это выражается как обращение к трансцендентному [Sarkar, 1978]. Наблюдения упомянутых авторов отражают сущность трансформации, когда идеи, практики и идентичности эволюционируют, взаимодействуя с меняющейся реальностью.

Оба типа согласуются с категориями стратегий будущего, рассмотренными ранее. «Закрытые» стратегии свойственны культуре первого типа, делающей ставку на безопасность. «Открытые» соответствуют культуре второго типа и отличаются гибридностью, позитивным отношением к переменам. В рамках той или иной культуры человеческий потенциал усиливается или ослабляется.

Далее, необходимо осознать роль, которую представления о прошлом, настоящем и будущем играют в определении того, что считать возможным. Для этого целесообразно применить «треугольник будущего» (futures triangle) (рис. 1) [Inayatullah, 2008] и с его помощью провести

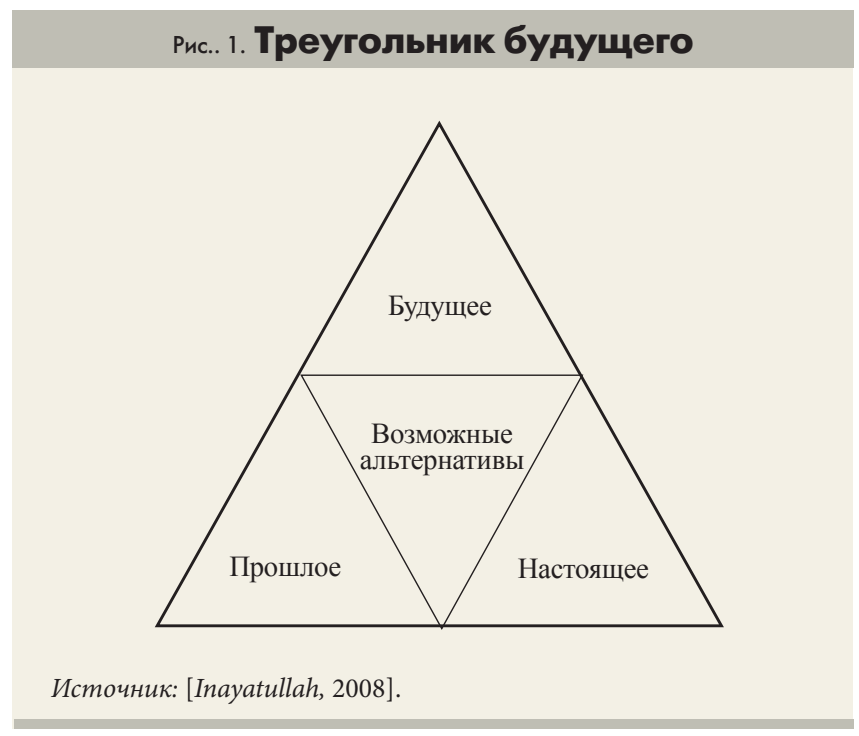


Рис.. 2. «Блоки», «разрывы» и «друзья» будущего

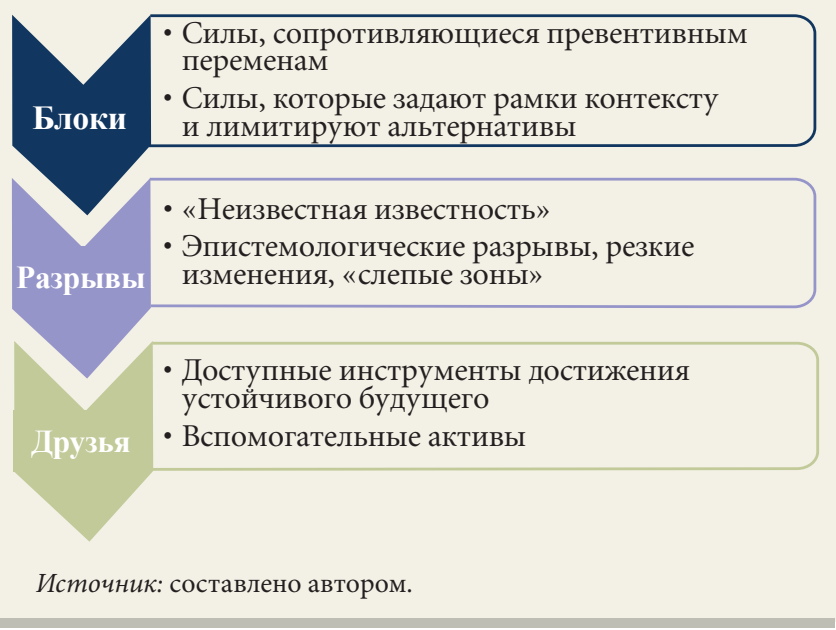

своеобразную «инвентаризацию», идентифици ровать источники элементов контекста - «корни» прошлого, современные тренды либо предположения и устремления, связанные с будущим.

О прошлом часто судят по генеалогическим сведениям [Foucault, 2005]. Одна из главных причин «закрытых» стратегий - память прошлого (многочисленные воспоминания и хроники, прямо либо косвенно влияющие на культуру). Турбулентное настоящее может отвергаться реакцией, описываемой как «шок настоящего» (present shock) [Rushkoff, 2013]. Однако при должной мотивации оно воспринимается как набор возмож ностей и ограничений, который расширяется за счет идентификации неочевидных факторов, обозначенных Д. Рамсфелдом как «неизвестная известность» (unknown knowns). Будущее как объект ожиданий, устремлений и предчувствий побуждает к действиям. Нерешительным людям оно представляется как набор потенциальных угроз, сильные личности воспринимают его как пространство бесконечных перспектив. Форсайт не «впадает» ни в ту, ни другую крайность, а ори ентируется на предупреждение, трансформацию и предпочтительные варианты будущего (preferred futures, futurables) [Godet, 2010, p. 1458]. На стыке прошлого, настоящего и будущего опознаются скрытые возможности [Bussey, 2009a].

Следует также учитывать присущие контексту «блоки» (blocks), «друзей» (friends) и «разрывы» (gaps) (рис. 2). Стейкхолдеры обладают специальными компетенциями, позволяющими им выявить эти факторы [Hooghe, Stolle, 2003]. «Блоки» будущего это фиксированные параметры и дискурсы, определяющие смысловые значения и образ действий. Опыт и знания игроков способствуют оперативной идентификации сил, сопротивляющихся переменам. Анализ «блоков» помогает подготовить почву для конструктивного диалога, в котором выявляются «друзья будущего» - элементы организационной либо общественной культуры, способствующие позитивным переменам (компетенции, знания, память и сети).
Между «блоками» и «друзьями» находится неотьемлемая часть контекста - разрывы, так называемые «слепые зоны» [Fukuyama, 2007], вмещающие «неизвестную известность». [Bussey, 2009b]. Это аспекты массовой культуры, которые по какой-то причине не учитывались, оказались отвергнутыми либо «забытыми». CLA служит эффективным инструментом для выявления «разрывов». Но иногда они лежат на поверхности, и требуется всего лишь смелость, чтобы их признать. Д. Адамс обозначил их как «чужие проблемы» (somebody else's problem) [Adams, 1982].

Понимание культуры позволяет переосмыслить настоящее как «уникальное коллективное путешествие», разработать превентивные стратегии, выявлять ценные элементы и исключить бесполезные. Для подобной работы необходимо владеть развитым практическим воображением.

\section{Практическое воображение}

Воображение - еще одна концепция, помогающая представить зарождающуюся реальность. Естественная способность человека к генерации и распространению концепций, впервые сформулированная Р. Докинзом [Dawkins, 1989], сыграла решающую роль в его развитии. Сочетая индивидуальные и коллективные интересы, она по определению носит прагматичный характер.

Работу этого принципа наглядно демонстрирует ситуация, в которой оказались первобытные охотники, озабоченные поиском пропитания в условиях ледникового периода. Представим себе, что, скорее всего, они собрались у костра, чтобы обсудить эту проблему. В процессе беседы родилась идея посеять часть семян от предыдущего урожая и попробовать их взращивать. Так появилась агрокультура. В ходе подобных дискуссий, сравниваемых Уэллсом с «инновационными фабриками мысли» [Wells, 2012, р. 112], и проявляется практическое воображение, которое меняет способы создания благ.

Дж. Ледерах [Lederach, 2005] описывает примеры «мягкого» преодоления конфликтных ситуаций при помощи идентификации «блоков», «разрывов» и «друзей» будущего. Как правило, процесс всегда инициирует небольшая группа, которая пытается сканировать будущее. Задача решается путем сочетания воли, социального капитала группы и практического воображения. Последнее, в свою очередь, требует: способности вообразить себя в сети, в которую входят оппоненты; умения принимать сложность без опоры на дуалистическую полярность; убежденности в действенности творческих подходов; готовности выйти за рамки привычных методов решения проблем в зону риска [ibid., p. 5]. Это дает основание рассматривать данный тип воображения как комбинацию персональной, социальной, культурной и трансформационной составляющих, каждая из которых предполагает ответ на ряд вопросов (рис. 3). Как видно из представленной схемы, указанные концепции согласуются 


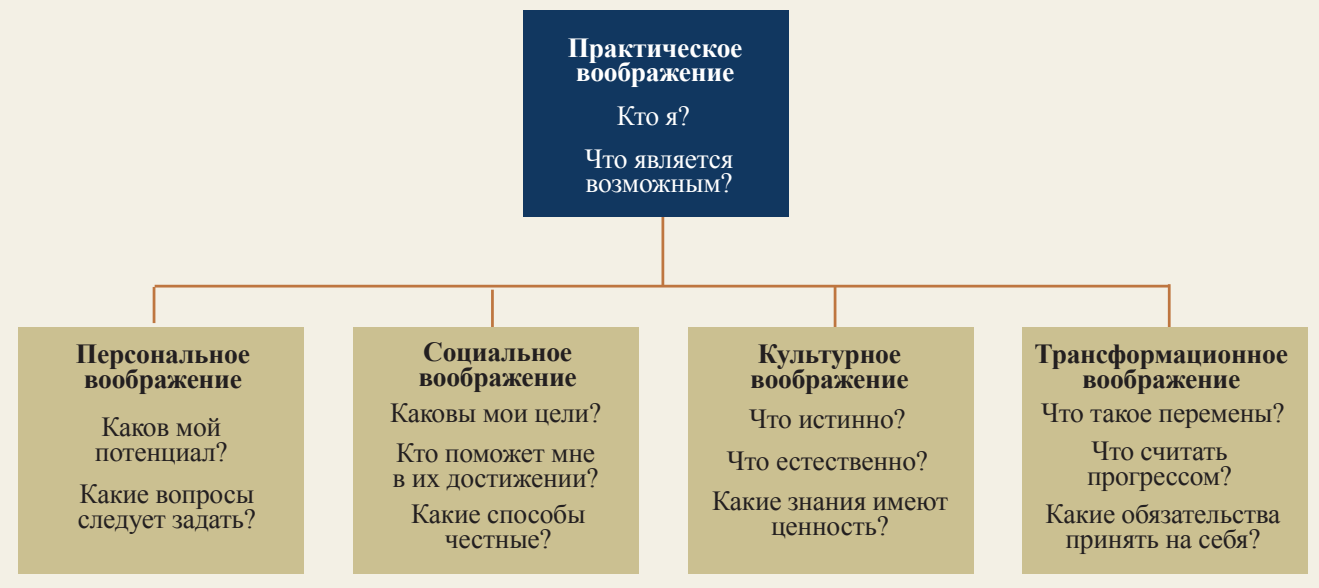

Источник: составлено автором.

между собой. Вопросы, связанные с определением идентичности («Кто я?», «Каков мой потенциал?», «Какие вопросы следует задать?»), выявляют роль личностного фактора в эмоциональных аспектах будущего, причинно-следственных связей и культуры. Они коррелируют с вопросами, относящимися к «сферам компетенции» «треугольника будущего»и аудита будущего, в ходе которого исследуются «блоки», «разрывы» и «друзья».

При углубленном поиске становятся очевидными эффекты концепций, обусловленные как индивидуальным, так и коллективным поведением. На повестку выходят вопросы о цели, справедливости, истинности, естественности и ценностях.

По мере обнаружения «слепых пятен» в фокусе оказываются новые конфигурации возможного. Здесь начинают работать предвосхищающие измерения Форсайта. Вопросы типа «Что такое перемены?» и «Что считать прогрессом?», в конечном счете, приводят к решению о том, какие обязательства на себя принять.

Для достижения этого уровня требуется нечто большее, чем просто методика. Чтобы развить практическое воображение необходимо синтезировать персональное с коллективным. Для этого, по словам Дж. Ледераха, требуется «умение увидеть в реальности нечто, способное породить то, что еще не существует» [ibid., p. 9]. Каждый участник должен воспринимать будущее как руководство к действиям. Практическое воображение основывается на способности предвидеть перспективы в условиях массивных потоков информации, многослойных причинных цепочек, множественных культурных контекстов и неопределенности.

\section{Предвосхищение}

Оно основано на открытости Форсайт-исследований и силах, побуждающих человека конструировать будущее, - внешнем давлении, с одной стороны, и внутренней установке «я могу создать свой сценарий жизни» - с другой. Предвосхищение связано с ожиданием новых перспектив, что имеет значение в любой футурологической практике, поскольку отношение к будущему лишь как к объекту негативных предчувствий снижает способность к проактивной реакции. Но следует помнить, что здоровая доля опасения по поводу вероятных негативных событий стимулирует к действиям. Таким образом, превентивные стратегии будущего и Форсайт предлагают и «кнут», и «пряник»: они встроены в пласт возможностей, побуждают к поиску лучших вариантов будущего и выходу за пределы достижимого.

\section{Заключение}

Будущее как категория для обучения основывается на определенном специфическом контексте Форсайта, что делает его прагматичным, нацеленным на расширение потенциала заинтересованных сторон. Подобная ориентация может быть неприемлемой с точки зрения «закрытой» стратегии будущего, в которой ограниченный подход предлагает весьма относительное превосходство. При наличии «открытых» стратегий на повестку выходит этический аспект, предполагающий извлечение преимуществ не на основе «игры с нулевой суммой», а партисипативности и сотворчества, что повышает потенциал всех систем и связей между ними. Подобный принцип учитывает интересы различных акторов и создает предпосылки к трансформациям, в то же время предусматривая вероятность негативных событий, что и составляет основу социальной функции Форсайта. При том что этот процесс носит глубоко индивидуальный характер, он обладает необходимой концептуальной четкостью. Благодаря ясности повышается результативность Форсайта в решении стоящих задач, укрепляется мотивация участников к постоянному пересмотру личных интересов в контексте этики отношений, где парадигма взаимной выгоды становится конечным индикатором эффективности. 
Adams D. (1982) Life, the Universe and Everything. London: Pan Macmillan.

Brandom R.B. (2008) Between Saying and Doing: Towards an Analytic Pragmatism. Oxford: Oxford University Press.

Bussey M. (2008) A World of Exception: Exploring the Thought of Loren Eiseley // Death and Anti-Death: Thirty Years after Loren Eiseley /

Ed. C.C. Tandy. Palo Alto, CA: Ria University Press. Vol. 5. P. 165-196.

Bussey M. (2009a) Causal Layered Pedagogy: Rethinking Curricula Practice // Journal of Futures Studies. Vol. 13. № 3. P. $19-32$.

Bussey M. (2009b) Six Shamanic Concepts: Exploring the Between in Futures Work // Foresight. Vol. 11. № 2. P. $29-42$.

Bussey M. (2010) Microvita and Transformative Information // The Open Information Science Journal. Vol. 3. P. 28-39.

Bussey M., Bjurström Å., Sannum M., Shambushivananda A., Bernard M., Ceruto L., Denis M., Giri A.K., Mukherjee A., Pervyi G., Pineda M.V. (2012a) Weaving Pedagogies of Possibility. Learning for Sustainability in Times of Accelerating Change / Eds. A.E.J. Wals,

P.B. Corcoran. Wageningen, NL: Wageningen Academic Publishers.

Bussey M., Carter R.W., Keys N., Carter J., Mangoyana R., Matthews J., Nash D., Oliver J., Roiko A., Richards R., Thomsen D.C., Sano M., Weber E., Smith T.F. (2012b) Framing Adaptive Capacity through a History-Futures Lens: Lessons from the South East Queensland Climate Adaptation Research Initiative // Futures. Vol. 44. № 4. P. 385-397.

BV S.I. (2008) Scenarions: An Exlorer's Guide. Shell. Режим доступа: www.shell.com/scenarios, дата обращения 14.04.2013.

Calasso R. (1993) The Marriage of Cadmus and Harmony. New York: Alfred A. Knopf.

Campbell J. (2008) The Hero with a Thousand Faces. Novato, CA: New World Library.

Christian D. (2004) Maps of Time: An Introduction to Big History. Berkeley: University of California Press.

Dator J.A. (2002) Introduction: The Future Lies Behind - Thirty Years of Teaching Futures Studies // Advancing Futures: Futures Studies in Higher Education / Eds. J. Dator, A. Westort. Connecticut: Praeger. P. 1-33.

Dawkins R. (1989) The Selfish Gene. Oxford: Oxford University Press.

Deleuze G., Guattari F. (1987) A Thousand Plateaus: Capitalism and Schizophrenia. London, New York: Continuum.

Derrida J. (2002) Writing and Difference. London: Routledge.

Dewey J. (1997) Democracy and Education: An Introduction to the Philosophy of Education. New York: The Free Press.

Ferruci P. (2004) What We May Be: Techniques for Psychological and Spiritual Growth through Psychosynthesis. London: Tarcher/Penguin. Foucault M. (2005) The Order of Things: An Archaeology of the Human Sciences. London, New York: Routledge.

Fukuyama F. (ed.) (2007) Blindside: How to Anticipate Forcing Events and Wild Cards in Global Politics. Washington, DC: Brookings Institution Press.

Gershon D. (2009) Social Change 2.0: A Blueprint for Reinventing Our World. New York: High Point.

Godet M. (2010) Future Memories // Technological Forecasting \& Social Change. Vol. 77. P. 1457-1463.

Hawken P. (2007) Blessed Unrest: How the Largest Movement in the World Came into Being and Why No One Saw It Coming. New York: Viking.

Hooghe M., Stolle D. (2003) Generating Social Capital: Civil Society and Institutions in Comparative Perspective. New York: Palgrave Macmillan.

Inayatullah S. (ed.) (2004) The Causal Layered Analysis (CLA) Reader: Theory and Case Studies of an Integrative and Transformative Methodology. Tamsui, Taiwan: Tamkang University Press.

Inayatullah S. (2007) Questioning the Future: Methods and Tools for Organizational and Societal Transformation. Taipei, Taiwan: Tamkang University.

Inayatullah S. (2008) Mapping Educational Futures: Six Foundational Concepts and the Six Pillars Approach // Alternative Educational Futures: Pedagogies for Emerging Worlds / Eds. M. Bussey, S. Inayatullah, I. Milojevic. Rotterdam: Sense Publishers. P. 13-41.

Inayatullah S. (2008) Six Pillars: Futures Thinking for Transforming // Foresight. Vol. 10. № 1. P. 4-21.

James W. (1896) The Will to Believe: And Other Essays in Popular Philosophy. Longmans, Green. Режим доступа: http://books.google.com. sg/books?id=wRMXL4uYEegC\&pg=PA124\&redir_esc=y, дата обращения 15.07.2013.

Korten D.C. (2006) The Great Turning: From Empire to Earth Community. Bloomfield, CT: Kumarian Press.

Lakoff G. (2005) Don't Think of an Elephant: Know Your Values and Frame the Debate. Melbourne: Scribe Short Books.

Lederach J.P. (2005) The Moral Imagination: The Art and Soul of Building Peace. Oxford: Oxford University Press.

Macy J. (2007) World as Lover, World as Self. Berkeley, CA: Parallax Press.

Matthews J., Hattam R. (2008) Did Buddha Laugh? A Pedagogy for the Future // Alternative Educational Futures: Pedagogies for Emerging Worlds / Eds. M. Bussey, S. Inayatullah, I. Milojevic. Rotterdam: Sense Publishers. P. 213-223.

Parkin S. (2010) The Positive Deviant: Sustainability Leadership in a Perverse World. London: Earthscan.

Peirce C.S. (2001) The Philosophy of Peirce: Selected Writings. New York: Routledge.

Pinker S. (2011) The Better Angels of Our Nature: Why Violence has Declined. New York: Penguin Books.

Rushkoff D. (2013) Present Shock: When Everything Happens Now. New York: Current Hardcover.

Sarkar P.R. (1978) Supreme Expression 1. 's-Hertogenbosch, The Netherlands: Nirvikalpa Printing.

Slaughter R., Bussey M. (2005) Futures Thinking for Social Foresight. Taipei: Tamkang University Press.

Stone H., Stone S. (1989) Embracing Ourselves: The Voice Dialogue Manual. Novato, CA: New World Library.

Thompson W.I. (2004) Self and Society: Studies in the Evolution of Consciousness. Charlottesville, VA: Imprint Academic.

Wells S. (2010) Pandora’s Seed: The Unforeseen Cost of Civilization. New York: Random House. 


\title{
Conceptual Frameworks of Foresight and Their Effects: Typology and Applications
}

\author{
Marcus Bussey \\ Lecturer in History and Futures, Faculty of Arts and Business, and Research Fellow, Regional Futures, \\ Sustainability Research Centre. E-mail: MBussey@usc.edu.au \\ University of the Sunshine Coast \\ Address: University of the Sunshine Coast, Locked Bag 4, Maroochydore DC, Queensland, 4558 Australia
}

\begin{abstract}
$\mathrm{T}$ his article assesses foundational concepts in foresight and futures studies. It uses terms matching definitions supplied by other scholars. It argues that certain concepts underly the practice of foresight; although each foresight context and practitioner are unique, they come together under these concepts and give coherence to foresight and futures practice. Clarity regarding the conceptual framework of foresight practice strengthens the field and enables better decision making on the choice of tools to guide and validate practice.

There are two principally distinct approaches to elaborating future strategies - open and closed. The first presumes quest and comparison of alternatives, behavior toward risk, and personal and social resilience. The second presumes risk aversion, or relying on

a «proven» pattern while weeding out unsustained ideas and initiatives. The latter results in decreasing personal and social resilience. The article evaluates conditions fostering one or the other approach. An appreciation of the relative "closedness» or "openness» of any context allows looking for elements that either enable or block the shift from closed to open futures. Much of the foresight practitioner's work involves helping stakeholders undertake such an inquiry and seeding the resilience needed to manage both the turbulence and the ensuing uncertainty that results from this shift.

The author believes that seeing foresight work and the futures thinking that accompanies it as promoting the journey from closed to open futures is a powerful insight into why foresight practice is so exciting.
\end{abstract}

\section{Keywords}

concepts; effects; pattern; patterning; open and closed futures; causality; foresight practice

\section{References}

Adams D. (1982) Life, the Universe and Everything, London: Pan Macmillan.

Brandom R.B. (2008) Between Saying and Doing: Towards an Analytic Pragmatism, Oxford: Oxford University Press.

Bussey M. (2008) A World of Exception: Exploring the Thought of Loren Eiseley. Death and Anti-Death: Thirty Years after Loren Eiseley (ed. C.C. Tandy), Palo Alto, CA: Ria University Press, vol. 5, pp. 165-196.

Bussey M. (2009) Causal Layered Pedagogy: Rethinking Curricula Practice. Journal of Futures Studies, vol. 13, no 3, pp. 19-32.

Bussey M. (2009) Six Shamanic Concepts: Exploring the Between in Futures Work. Foresight, vol. 11, no 2, pp. 29-42.

Bussey M. (2010) Microvita and Transformative Information. The Open Information Science Journal, vol. 3, pp. 28-39.

Bussey M., Bjurström Å., Sannum M., Shambushivananda A., Bernard M., Ceruto L., Denis M., Giri A.K., Mukherjee A., Pervyi G., Pineda M.V. (2012) Weaving Pedagogies of Possibility. Learning for Sustainability in Times of Accelerating Change (eds. A.E.J. Wals, P.B. Corcoran), Wageningen, NL: Wageningen Academic Publishers.

Bussey M., Carter R.W., Keys N., Carter J., Mangoyana R., Matthews J., Nash D., Oliver J., Roiko A., Richards R., Thomsen D.C., Sano M., Weber E., Smith T.F. (2012) Framing Adaptive Capacity through a History-Futures Lens: Lessons from the South East Queensland Climate Adaptation Research Initiative. Futures, vol. 44, no 4, pp. 385-397.

BV S.I. (2008) Scenarions: An Exlorer's Guide, Shell. Available at: www.shell.com/scenarios, accessed 14.04.2013.

Calasso R. (1993) The Marriage of Cadmus and Harmony, New York: Alfred A. Knopf.

Campbell J. (2008) The Hero with a Thousand Faces, Novato, CA: New World Library.

Christian D. (2004) Maps of Time: An Introduction to Big History, Berkeley: University of California Press.

Dator J.A. (2002) Introduction: The Future Lies Behind - Thirty Years of Teaching Futures Studies. Advancing Futures: Futures Studies in Higher Education (eds. J. Dator, A. Westort), Connecticut: Praeger, pp. 1-33.

Dawkins R. (1989) The Selfish Gene, Oxford: Oxford University Press. 
Deleuze G., Guattari F. (1987) A Thousand Plateaus: Capitalism and Schizophrenia, London, New York: Continuum.

Derrida J. (2002) Writing and Difference, London: Routledge.

Dewey J. (1997) Democracy and Education: An Introduction to the Philosophy of Education, New York: The Free Press.

Ferruci P. (2004) What We May Be: Techniques for Psychological and Spiritual Growth through Psychosynthesis, London: Tarcher/Penguin. Foucault M. (2005) The Order of Things: An Archaeology of the Human Sciences, London, New York: Routledge.

Fukuyama F. (ed.) (2007) Blindside: How to Anticipate Forcing Events and Wild Cards in Global Politics, Washington, DC: Brookings Institution Press.

Gershon D. (2009) Social Change 2.0: A Blueprint for Reinventing Our World, New York: High Point.

Godet M. (2010) Future Memories. Technological Forecasting \& Social Change, vol. 77, pp. 1457-1463.

Hawken P. (2007) Blessed Unrest: How the Largest Movement in the World Came into Being and Why No One Saw It Coming, New York: Viking.

Hooghe M., Stolle D. (2003) Generating Social Capital: Civil Society and Institutions in Comparative Perspective, New York: Palgrave Macmillan.

Inayatullah S. (ed.) (2004) The Causal Layered Analysis (CLA) Reader: Theory and Case Studies of an Integrative and Transformative Methodology, Tamsui, Taiwan: Tamkang University Press.

Inayatullah S. (2007) Questioning the Future: Methods and Tools for Organizational and Societal Transformation, Taipei, Taiwan: Tamkang University.

Inayatullah S. (2008) Mapping Educational Futures: Six Foundational Concepts and the Six Pillars Approach. Alternative Educational Futures: Pedagogies for Emerging Worlds (eds. M. Bussey, S. Inayatullah, I. Milojevic), Rotterdam: Sense Publishers, pp. 13-41.

Inayatullah S. (2008) Six Pillars: Futures Thinking for Transforming. Foresight, vol. 10, no 1, pp. 4-21.

James W. (1896) The Will to Believe: And Other Essays in Popular Philosophy, Longmans, Green. Available at: http://books.google.com.sg/ books?id=wRMXL4uYEegC\&pg=PA124\&redir_esc=y, accessed 15.07.2013.

Korten D.C. (2006) The Great Turning: From Empire to Earth Community, Bloomfield, CT: Kumarian Press.

Lakoff G. (2005) Don't Think of an Elephant: Know Your Values and Frame the Debate, Melbourne: Scribe Short Books.

Lederach J.P. (2005) The Moral Imagination: The Art and Soul of Building Peace, Oxford: Oxford University Press.

Macy J. (2007) World as Lover, World as Self, Berkeley, CA: Parallax Press.

Matthews J., Hattam R. (2008) Did Buddha Laugh? A Pedagogy for the Future. Alternative Educational Futures: Pedagogies for Emerging Worlds (eds. M. Bussey, S. Inayatullah, I. Milojevic). Rotterdam: Sense Publishers, pp. 213-223.

Parkin S. (2010) The Positive Deviant: Sustainability Leadership in a Perverse World, London: Earthscan.

Peirce C.S. (2001) The Philosophy of Peirce: Selected Writings, New York: Routledge.

Pinker S. (2011) The Better Angels of Our Nature: Why Violence has Declined, New York: Penguin Books.

Rushkoff D. (2013) Present Shock: When Everything Happens Now, New York: Current Hardcover.

Sarkar P.R. (1978) Supreme Expression 1, 's-Hertogenbosch, The Netherlands: Nirvikalpa Printing.

Slaughter R., Bussey M. (2005) Futures Thinking for Social Foresight, Taipei: Tamkang University Press.

Stone H., Stone S. (1989) Embracing Ourselves: The Voice Dialogue Manual, Novato, CA: New World Library.

Thompson W.I. (2004) Self and Society: Studies in the Evolution of Consciousness, Charlottesville, VA: Imprint Academic.

Wells S. (2010) Pandora's Seed: The Unforeseen Cost of Civilization, New York: Random House. 


\title{
Государственные научные организации. Взаимодействие науки и реального сектора экономики
}

\author{
18-19 июля 2013 г.
}

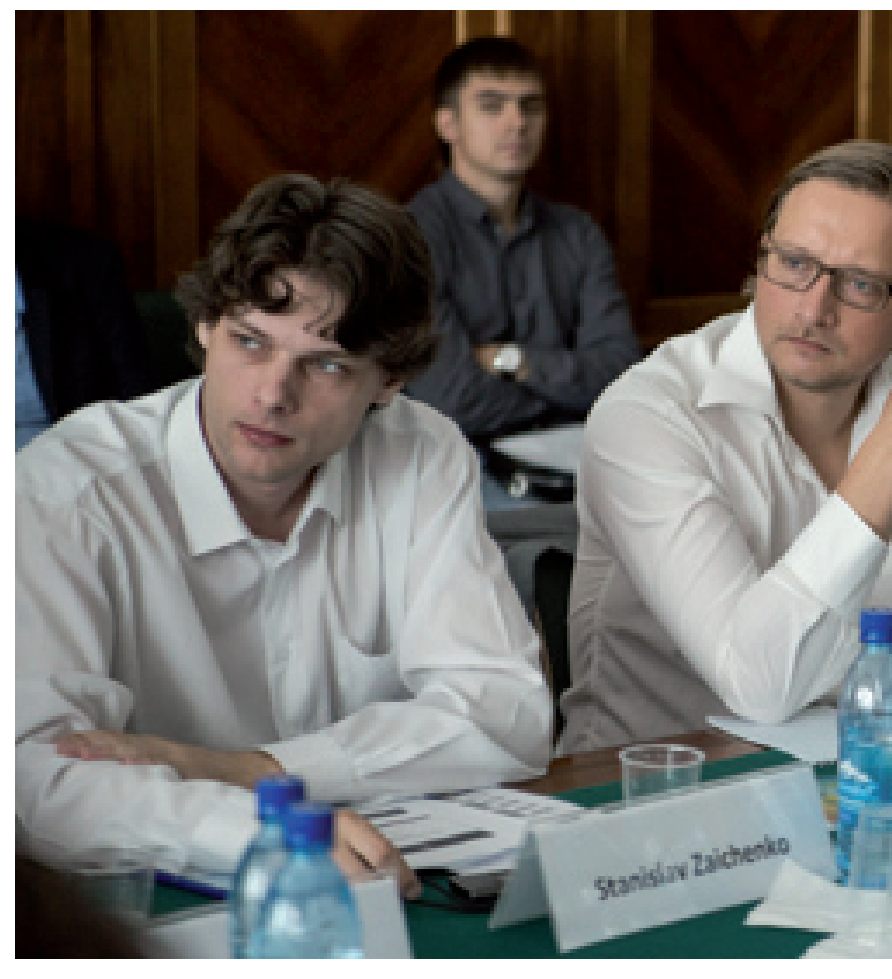

Предметом международного семинара, организованного Лабораторией экономики инноваций ИСИЭЗ НИУ ВШЭ, стали исследования связей науки и реального сектора экономики.

Обсуждались следующие темы:

- Уроки многолетних исследований связей между государственными научными организациями и промышленными инновациями в контексте инновационных систем.

- Глобальная эволюция институциональных и финансовых механизмов государственного сектора науки. Ее основные драйверы и последствия.

- Формы проявления спроса на оценивание эффективности научных организаций. Стратегии и инструменты для его проведения на индивидуальном, институциональном и системном уровнях.

- Наиболее востребованные направления исследований.

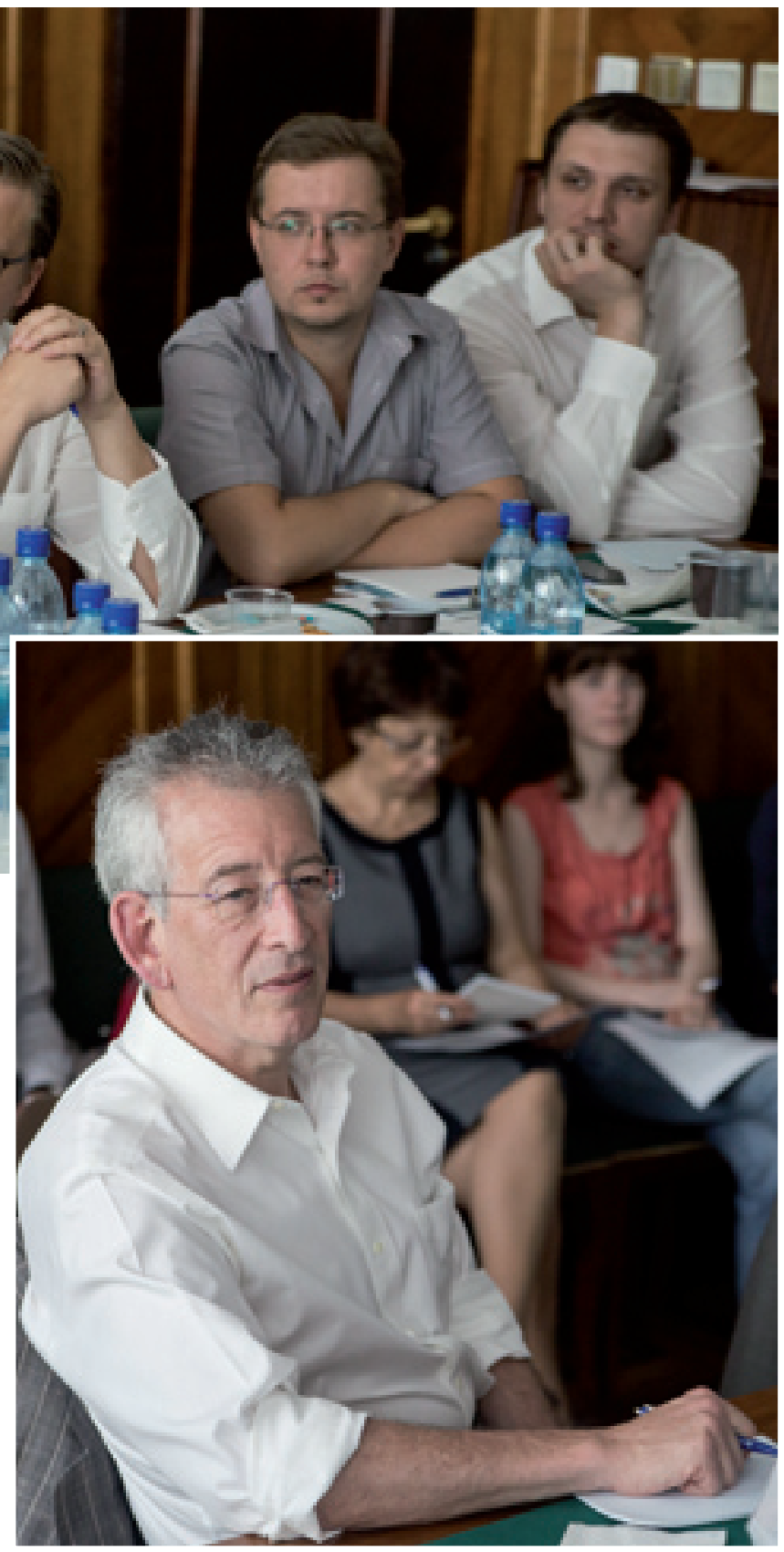

В семинаре приняли участие сотрудники Лаборатории экономики инноваций и ИСИЭЗ НИУ ВШЭ, ученые из университетов Манчестера и Брайтона (Великобритания), Университета Твенте (Нидерланды) и Национального исследовательского совета Италии. 


\section{Наука и реальный сектор экономики - ландшафт взаимодействия}

За последние десятилетия в результате активных исследований сформировался солидный массив теоретических и методологических подходов к анализу и оценке «социальной функции» науки. Выявлено, что взаимодействие между участниками инновационной системы характеризуется разнообразием стратегий поведения, конфигурацией кооперационных связей, страновых и секторальных закономерностей.

Открывая семинар, первый проректор НИУ ВШЭ, директор ИСИЭЗ Леонид Гохберг подчеркнул актуальность его тематики на фоне масштабных институциональных сдвигов, связанных с изменением роли научных организаций и университетов в России.

До недавнего времени участие университетов в научной деятельности было минимальным. Сегодня же на активизацию их исследовательской функции выделяются значительные организационные и финансовые ресурсы. Тем не менее роль научных организаций в новой модели инновационной системы остается центральной темой для дискуссий.

Руководитель Лаборатории экономики инноваций Йен Майлс (Ian Miles) представил краткий исторический обзор развития исследований в сфере анализа деятельности научных организаций. Начало этому процессу положил в 1931 г. Международный конгресс по истории науки и технологий. В его рамках интерналистское мировоззрение (представление о том, что наука, по своей внутренней логике, сама по себе развивается эффективно и на благо общества) столкнулось с марксистским взглядом на роль научно-технологического прогресса в решении социально-экономических проблем своего времени. Дж. Д. Бернал развил эту дихотомию, описывая конфликт между прогрессивистскими взглядами, верой в безусловное улучшение условий жизни и шоком от деструктивного вклада технологий в Первой мировой войне и последующем экономическом кризисе ${ }^{1}$. Все чаще стали звучать призывы к усилению общественного контроля над приоритетами и направлениями исследований. Ученые были вынуждены переосмыслить характер своей деятельности и ответственность перед обществом. К этому периоду относятся первые исследования в области научной политики и наукометрии. Чуть позже указанные подходы легли в основу Руководства Фраскати и количественного анализа сферы науки и инноваций. Прослеживается сдвиг фокуса исследований: от вопросов, касающихся государственного финансирования науки, исследований трендов научной активности, измерения ресурсов и результатов - к управлению инновационной деятельностью, инновациям, осуществляемым без выполнения исследований и разработок (ИиР), оценке эффективности процессов распространения знаний. Таким образом, накопленные теоретические взгляды и эмпирические наблюдения сформировали представления об инновационных системах как центральном объекте анализа.

Одним из ключевых концептуальных элементов дискуссии стала так называемая линейная модель ин- новаций, сформированная на ранних этапах развития теории, но до сих пор не исчезнувшая из поля зрения. Она подразумевает демаркацию различных этапов инновационной активности и упорядочивание их в линейной связи - фундаментальные и прикладные исследования, разработка технологий, коммерциализация (инновации). Вместе с тем линейная модель оставляет неопределенности и создает почву для мифов о местах локализации тех или иных этапов инновационного цикла. Так, в западных странах бытует мнение, что фундаментальные исследования осуществляются исключительно в университетах, прикладные - в научных организациях, тогда как разработка технологий - прерогатива индустрии. Между тем практика показывает, что состав этих этапов, порядок их реализации может существенно варьироваться при различных стратегиях инновационной деятельности. Более того, само разделение на стадии становится не столь явным. Так, на границе между фундаментальной и прикладной наукой возникают стратегические исследования в интересах компаний и правительств. Прикладные тематики и разработку новых технологий объединяют «живые лаборатории» (living labs), в которых реальный мир используется для тестирования гипотез. Грань между технологиями и их приложением стирает феномен пользовательских инноваций. Совокупность неопределенностей, а также высокая вариативность взаимосвязей между отдельными частями ведут к дифференциации инновационных процессов по странам и секторам, и, следовательно, к расширению разнообразия взаимосвязей между наукой (представленной научными организациями и университетами), бизнесом и государством.

Сегодня научные организации считаются одним из наименее изученных элементов инновационных систем. Отсутствует консенсус по таким значимым вопросам, как независимость исследований в условиях растущих формальных связей научного сообщества с компаниями, эффективность организаций, измеряемая в терминах библиометрических индикаторов, а также институт экспертизы при определении будущих приоритетов.

Меняется и политика: в условиях ограниченности ресурсов остро встают вопросы приоритезации, усиливается нацеленность на глобальные вызовы, хотя страны и различаются по институциональным моделям, степени концентрации финансирования, критериям отбора и оценки программ.

Докладчик завершил выступление, сформулировав ряд открытых вопросов:

- Насколько меняются роль и взаимосвязи научных организаций, и в какой степени этот процесс управляем?

- В какой мере исследователям и разработчикам политики следует учитывать разнообразие и сопутствующую сложность цепочек взаимодействия?

- В какой степени связи и их изменения поддаются измерению и оценке?

- Насколько систематизирован и глубок опыт оценивания, пригодны ли полученные знания к межстрановому применению? 
Сессию продолжил доклад научного сотрудника Лаборатории экономики инноваций НИУ ВШЭ Виталия Рудя «Российская промышленность: режимы ИиР и связи с государственным сектором науки». Переходя от концептуального описания ключевых постановок к количественному анализу феномена исследовательской деятельности российских компаний, он представил эмпирические характеристики взаимодействия промышленных предприятий и научных организаций. С использованием эконометрической модели дискретного последовательного выбора были проанализированы факторы, влияющие на вовлечение предприятий в ИиР и на возможную кооперацию с внешними исполнителями. Данные по отдельным предприятиям позволили оценить эффекты таких факторов, как размер, форма собственности, сектор экономики и региональная специфика.

Основной вывод автора: ИиР являются дорогостоящей и сложной стратегией по реализации инноваций, свойственной крупным компаниям. Интенсивность вложений в науку существенно зависит как от размера организации, так и от стратегии сотрудничества: наиболее затратной оказывается полноценная научная кооперация, сопровождающаяся как внутренними ИиР, так и контрактами со сторонними партнерами. С минимальными затратами связана стратегия полного аутсорсинга ИиР, при этом встает вопрос о качестве результирующих инноваций. По сравнению с влиянием на вероятность вовлечения в ИиР факт начала кооперации гораздо слабее связан с размером компании. Решающую роль здесь играет секторальная специфика, что говорит о существенной гетерогенности эффективности связи между отечественной наукой и бизнесом в зависимости от вида экономической деятельности.

Анализ влияния формы собственности выявил в целом более активное вовлечение в ИиР организаций с государственным участием. Интересно отметить, что компании иностранной либо смешанной иностранной собственности существенно менее склонны к проведению ИиР в России. В случае же начала ИиР такие компании инвестируют значительно больше типичных российских частных и государственных предприятий, и основная часть этих средств тратится на аутсорсинг у зарубежных научных организаций.

Секторальная специфика оказывает ключевое влияние на вероятность интеграции с российской наукой. Наиболее результативны установившиеся связи в сфере нефтехимии, производства кокса и ядерного топлива. Следом идут сектора медицинской техники, точного машиностроения, а также химическая промышленность в целом. Аутсайдерами кооперации, полностью зависимыми от притока технологий со стороны поставщиков оборудования, являются предприятия деревообработки и ряда секторов легкой промышленности.

Согласно оценкам со стороны бизнеса, его успешной кооперации с российской наукой препятствуют недостаток собственных финансовых средств и высокие экономические риски, недостаточная готовность научно-технических результатов к внедрению, нехватка квалифицированных инженеров и наличие более конкурентоспособных зарубежных разработок.
Далее выступил Эрик Арнольд (Erik Arnold), профессор Университета Твенте (University of Twente, Нидерланды); директор компании Technopolis Ltd. (Beликобритания), с докладом «Государственные научные организации в Европе» (Public Research Organisations in Europe). Говоря о месте научных организаций в инновационных системах европейских стран, докладчик заметил, что они зачастую воспринимаются как своего рода посредники в трансформации фундаментальных знаний в коммерциализуемые прикладные результаты. Вместе с тем можно выделить различные типы организаций, существенно отличающиеся по своим функциональным характеристикам, миссии и целям деятельности. Первый класс составляют научноисследовательские институты, такие как Общество Макса Планка (Max Planck Gesellschaft) в Германии, Национальный центр научных исследований (Centre national de la recherche scientifique, CNRS) во Франции и институты национальных академий наук. Они вовлечены в сходные с университетами виды исследований, а следовательно, формируют большую часть бюджета за счет базового и грантового финансирования. Ко второму можно отнести правительственные лаборатории, как правило, находящиеся в собственности государства (институты в области ядерных исследований, изучения морей и океанов и др., совмещающие прикладные исследования с фундаментальными). Они обеспечивают госаппарат экспертизой в релевантных областях, а основной доход получают от министерств, чьи функции поддерживают.

Наконец, выделяются научно-технологические организации (Фраунгоферовское общество (Fraunhofer Gesellschaft) в Германии, Центр технических исследований (VTT Technical Research Centre) в Финляндии, Opганизация прикладных научных исследований (Dutch Organization for Applied Scientific Research, TNO) в Нидерландах). Возникнув из лабораторий, где разрабатываются и тестируются продукты и технологии для промышленности, они переходят к контрактным проектам либо решают определенные научные проблемы для блага общества, получая финансирование на конкурсной основе.

Обобщая европейский опыт, докладчик выделил четыре потока в финансировании научных организаций: контракты с пользователями (промышленность, государство), конкурсное финансирование (программы национального и международного уровня), стратегические или «административные» исследования (для поддержки принятия решений и совершенствования регулирования), базовое финансирование (бюджетные средства на науку, платформы). Баланс между этими компонентами в общем бюджете организации в конечном счете и определяет ее специфику и роль в инновационной системе.

В качестве иллюстрации Э. Арнольд привел практику кооперации шведских компаний с различными институтами. Здесь научные организации рассматриваются как центры концентрации ресурсов и компетенций. Они профессионально управляют интеллектуальной собственностью, имеют опыт работы с предприятиями, навыки управления проектами, меньше сфокусированы на публикациях, по возможности привлекают 
дополнительную научную экспертизу. Университеты готовят высококвалифицированных специалистов, ведут фундаментальные исследования (в том числе на доконкурентной стадии), получают дополнительное финансирование от государства. Однако вузовские исследования не имеют четкого временного горизонта, а их результаты могут быть непредсказуемыми.

В свою очередь, усиливается интерес государства к центрам компетенций. В европейской практике они обычно финансируются тремя партнерами - компанией, университетом и государственным ведомством, интегрируя научную повестку университетов и расширяя горизонты планирования в вовлеченных компаниях с учетом сроков проведения ИиР. Деятельность таких центров часто носит междисциплинарный и проблемно-ориентированный характер, развивая горизонтальные связи между различными группами акторов. Они проводят качественные фундаментальные исследования, готовят профессиональные научные кадры для реального сектора, развивают отраслевую науку, продвигают открытые инновации, стимулируют совместные проекты компаний и академических структур, содействуют инновационной активности.

Старший научный сотрудник Лаборатории экономики инноваций НИУ ВШЭ Станислав Заиченко рассказал о государственных научных организациях в России. Он представил ретроспективный обзор процессов в отечественной науке, раскрыл содержание понятия «государственные научные организации» и сравнил государственный и негосударственный сегменты в современной научной системе. Была оценена преемственность современных научных организаций по отношению к советской модели. Как показывает статистика, институциональная система ИиР в 19902000 гг. не смогла в полной мере перестроиться вслед за социально-экономической трансформацией. Боль шинство научных организаций сохранили облик «отраслевых институтов», изолированных от высшего образования и реального сектора; основным источником финансирования ИиР остаются государственные средства; не устранены барьеры для самостоятельного развития в различных организационно-правовых формах. Кроме того, за постсоветский период число таких субъектов сократилось незначительно, тогда как затраты на науку в реальных ценах едва достигают половины от уровня 1990 г. Таким образом, очевидно системное недофинансирование существующего научно-технологического комплекса. В условиях рыночной экономики оно не может быть преодолено напрямую, но при этом ведет к потере конкурентоспособности последнего. Одним из признаков такой тенденции С. Заиченко считает стабильное снижение кадрового потенциала и результативности ИиР.

В этом контексте на первый план выходят вопросы о роли государства в развитии сферы науки и технологий, о различиях между государственными и негосударственными научными организациями и факторах их эффективности. Как отметил докладчик, в изучении данного вопроса (не только в России, но и в международной практике) до сих пор не выработаны подходы к формализованному выделению такой категории, как государственная научная организация. В частности, классическое определение государственного сектора науки, сформулированное в Руководстве Фраскати, не может служить надежным критерием. Как показывают международные исследования, во многих странах оно охватывает лишь часть государственных научных организаций, в то время как целый сегмент институтов, находящихся в собственности государства или получающих преимущественно бюджетное финансирование, по определению относится к предпринимательскому сектору. В то же время статистика определяет категорию государственной науки с точки зрения форм собственности, источников финансирования, выполняемых работ, статуса научных работников и пр.

Докладчик сравнил государственные и негосударственные научные организации по широкому спектру количественных показателей. К государственным были отнесены институты, находящиеся в государственной или смешанной собственности, а также те, для которых доля бюджетных средств в структуре финансирования ИиР превышает 50\%. В выборке не учитывались вузовский и академический секторы (по аналогии с «научно-технологическими организациями» в международной практике), а контрольным критерием служило наличие деятельности по передаче научнотехнических результатов в реальный сектор. Выявилось, что государственные научные организации в России производят «общественные блага» в биологических, медицинских и сельскохозяйственных науках, а также в фундаментальных и прикладных исследованиях (в отличие от разработок). Кроме того, они лидируют по объему затрат на ИиР (но испытывают острый недостаток в негосударственных источниках финансирования) и по численности научного персонала, нуждаясь тем не менее в притоке молодых исследователей. Указанные организации имеют открытый доступ к конкурсному финансированию и к вузам как источнику новых научных кадров. Однако они менее активны на рынках технологий, больше сосредоточены на самостоятельной научной деятельности, чем на технологической кооперации, и ориентированы скорее на подготовку и переподготовку специалистов, чем на оказание технологических услуг предприятиям.

Опираясь на статистическую вероятностную модель, автор продемонстрировал, что активность по передаче научно-технических результатов (технологий) в бизнес у государственных и негосударственных научных организаций выражена в одинаковой степени, но проявляется по-разному. В случае первых передача технологий требует более активного притока молодых кадров, развития научно-технологической кооперации и интенсификации предложения научно-технических услуг. Вторые произведут технологический трансфер с более высокой вероятностью при условии активной конкуренции с другими аналогичными институтами на стадии прикладных исследований и минимизации рисков. В обеих группах шансы на передачу повышаются при более активном привлечении негосударственных источников финансирования ИиР, интенсивном предоставлении услуг научной информации и внедрении формализованной стратегии развития, ориентированной на кооперацию с реальным сектором. 
В ходе дискуссии участники отметили широту представленного обзора, как с точки зрения выделенных исторических тенденций, так и по спектру рассмотренных характеристик. Это оказалось весьма полезным для формирования представлений о российской науке среди зарубежных экспертов, мало знакомых с ее спецификой. В то же время было отмечено, что количественные данные, представленные в докладе, не дают достаточной информации о внутреннем устройстве и поведении научных организаций и эта тема могла бы быть раскрыта в будущем посредством неформализованных интервью с их руководителями.

Томас Тернер (Thomas Thurner), ведущий научный сотрудник Лаборатории экономики инноваций НИУ ВШЭ, рассказал о последних исследованиях процессов создания и передачи технологий российскими научными организациями. Предметом анализа стали секторальные различия, в том числе в сельском хозяйстве, добывающей промышленности и обрабатывающих производствах. Предприятия дифференцировались по интенсивности затрат на ИиР с выделением низко-, средне- и высокотехнологичных секторов. Автор опирался на концепцию отраслевых инновационных систем, где научные организации выполняют как минимум две функции - создания и распространения нового знания.

Исследования подобных систем фокусируются на идентификации агентов и их взаимодействий в отдельных секторах экономики. По определению такие системы оперируют единой базой знаний, используют специфичные механизмы и предъявляют спрос на совершенствование технологий, обладающий определенными характеристиками. В центре современных исследований анализ характера передачи знаний между акторами, имеющими общие представления, цели, ожидания и стратегии развития. Объектом анализа становятся такие отрасли, как фармацевтическая промышленность, химические производства, телекоммуникации, программное обеспечение, производство машин и оборудования.

Секторальные различия проявляются также через вариации технологических возможностей и разные механизмы взаимодействия с источниками знаний. Если некоторые секторы выигрывают от новейших научных достижений, то другие могут сильно зависеть от прямого взаимодействия с потребителями. Технологии и темпы перемен оказываются схожими для акторов одного сектора и существенно различаются между отраслями. Подобные отличия проявляются эмпирически при сопоставительном анализе, в том числе межстрановом. Т. Тернер сделал вывод о существенной секторальной специфике поведения научных организаций в России. Причем при видимой схожести в терминах базовых индикаторов, стратегии различных секторов отличаются в деталях, в частности с точки зрения взаимодействия с компаниями. В заключение он заметил, что одним из ключевых факторов выступает совокупный уровень экономического благосостояния компаний - реципиентов технологий.

Научный сотрудник Лаборатории экономики инноваций НИУ ВШЭ Константин Фурсов представил возможные подходы к статистическому измерению результативности научно-технической деятельности на уровне страны и отдельной организации. Одной из основных проблем, задающих тон дискуссиям, является определение подхода к идентификации границ научной деятельности в экономических терминах и выбор соответствующих индикаторов, характеризующих различные ее виды. Следует учитывать, что если оценка ресурсного потенциала науки основывается на многолетнем опыте статистической практики и хорошо формализована, то измерение продукта ИиР зачастую опирается на авторские подходы и вызывает серьезные дискуссии.

Выделяются три вида результатов, доступных для измерения, - научные публикации, патенты и технологии. Анализ первых двух предполагает работу с национальными и международными базами данных, третьего - проведение статистических обследований. При этом любая полученная оценка требует тщательной интерпретации. Так, падение доли России в общемировом числе публикаций в научных журналах, индексируемых в базе Web of Science, за последние 10 лет может быть вызвано как более высокой активностью других стран, так и динамикой самой базы (т. е. увеличением общего числа индексируемых документов). С другой стороны, анализ глобальных тенденций показывает, что 20 стран-лидеров производят свыше 80\% всех мировых публикаций, что уменьшает шансы тех, кто находится на периферии рейтинга, быть замеченными коллегами (т. н. «эффект Матфея» в науке). Библиометрические индикаторы позволяют не только оценить «видимость» науки той или иной страны, но и рассмотреть ее научную специализацию, уровень интернационализации и международного признания. Патентование характеризует, прежде всего, уровень изобретательской активности, однако желание организаций конкурировать в значительной степени обусловлено состоянием рынка интеллектуальной собственности и уровнем доверия к национальному законодательству в этой области. Анализ разработки и использования технологий требует принципиально иного подхода и упирается, главным образом, в определение понятия «технология» и построение перечня технологических направлений, измерение которых возможно в рамках регулярных статистических наблюдений. В качестве примера был представлен российский опыт статистического исследования передовых производственных технологий.

Особое внимание выступавший уделил подходам к измерению результативности научной деятельности организаций. Используя в качестве иллюстрации исследование ИСИЭЗ НИУ ВШЭ, нацеленное на изучение факторов эффективности научных коллективов, К. Фурсов показал, что коллективные агенты научного производства (лаборатории, центры, институты) способны к спонтанной социальной самоорганизации в зависимости от стиля менеджмента, ресурсной обеспеченности и факторов внешней среды. Поэтому оценка их деятельности должна учитывать не только экономические, но и социальные факторы развития науки.

Профессор Говард Раш (Howard Rush), один из основателей Центра исследований менеджмента ин- 
новаций (Centre for Research in Innovation Management, CENTRIM) в Университете Брайтона (The University of Brighton, Великобритания) рассказал о возможных приложениях исследований в области общественных наук, обусловливающих востребованность последних в бизнесе или государственном управлении. В качестве примера он представил три проекта Центра по углубленному изучению управления инновациями.

Предметом первого - «Инновационные центры сложных продуктовых систем» (Complex Product Systems Innovation Centers, CoPS) стало изучение разработки и создания продуктов и систем, производимых штучно ввиду сложности, высокотехнологичности и интенсивного использования программного обеспечения. При этом инновационный цикл отличается нелинейностью, требует нестандартных подходов к управлению и нередко - кооперации нескольких компаний на различных стадиях.

Помимо значительного объема академического знания, полученного за десятилетний срок реализации проекта, было зафиксировано его влияние на инновационную политику. Выявить какое-либо воздействие непосредственно на организацию менеджмента инноваций в компаниях-участниках в краткосрочном периоде практически невозможно. Распростране нию полученных знаний могло бы способствовать включение результатов исследования в магистерские программы в различных странах.

Другой проект, Profitnet, был инициирован на региональном уровне администрацией Сассекса для изучения процесса создания малыми и средними компаниями сетей обмена знаниями. Стояла задача обучить ответственных представителей фирм работе в сетях и взаимодействию с представителями других компаний для обмена мнениями и опытом. Целевой аудиторией стали предприятия, не относящиеся к трем наиболее активно изучаемым категориям - созданным на базе новых технологий, быстрорастущим («газели») и средним. Проведенный в рамках проекта опрос участников выявил практическую полезность полученных ими навыков и зафиксировал усиление межфирменной кооперации. В результате реализации программы финансовые показатели вовлеченных организаций существенно улучшились в сравнении со средними по региону значениями.

Третий кейс - двухдневный курс «Управление инновациями» (Managing Innovations), разработанный на основе докторской диссертации, посвященной изучению поведения и организационной практики успешных инновационных компаний по всему миру. Об успехе проекта говорит не только отмечаемая участниками высокая удовлетворенность содержанием курса, но и его востребованность, выраженная ростом числа сертифицированных тренеров и прошедших обучение сотрудников различных компаний в 17 странах.

Опыт столь различающихся по многим параметрам проектов показал, что при определенных обстоятельствах вовлеченность в исследуемые процессы позволяет специалистам в области общественных наук получать знания, которые могут быть применены для улучшения ситуации в той или иной сфере деятельности напрямую и в сравнительно короткие сроки.

\section{Оценивание эффективности научных организаций}

В рамках семинара также рассматривалось измерение эффективности деятельности научных организаций, характеристик их производительности и результативности.

Марио Коччиа (Mario Cocchia), научный сотрудник Института экономических исследований фирм и роста (Institute for Economic Research on Firms and Growth, CERIS) Национального исследовательского совета Италии (National Research Council, CNR), представил опыт оценки результативности деятельности государственных научных институтов в Италии и их реструктуризации. Были рассмотрены меры по повышению продуктивности институтов CNR, предпринимавшиеся с конца 1990-х гг. До преобразований только четверть упомянутых организаций получали средства на ИиР из негосударственных источников, а основная часть находилась на попечении государства. В результате эксперты заключили, что главным барьером для технологической кооперации с реальным сектором являлся размер лабораторий, не позволявший реализовать крупные проекты по созданию и передаче технологий.

В ходе реформы произошло укрупнение малых научных организаций путем их слияния; отдельные лаборатории, утратившие свой профиль, были ликвидированы. Докладчик отметил, что вновь созданная структура приобрела выраженный вертикальный характер: более крупные единицы (институты) получили административные функции в отношении децентрализованных организаций, сформированных путем объединения мелких единиц. В то же время все научные работники сохранили свои места, поскольку оценка эффективности отдельных ученых блокировалась профсоюзом как акт дискриминации, а увольнение сотрудника государственной научной организации, имеющего в Италии статус госслужащего, весьма затруднительно. Поскольку инициированные в 1999 г. преобразования не повлияли на результативность системы государственных научных организаций, четырьмя годами позже начался новый этап реформ. Было решено стимулировать кооперацию институтов с реальным сектором. Созданная ранее вертикальная структура управления была дополнена «матричной» проектно-ориентированной системой.

C 2004 г. начались комплексные мониторинговые обследования институтов CNR, нацеленные на анализ последствий проведенных реформ. Выявилось, что деятельность институтов в рамках описанной модели (особенно - децентрализованных структур) стала менее управляемой. При сокращении вложений в ИиР повысились затраты на содержание организаций и административные расходы; снизилась интенсивность передачи технологий предприятиям. Лишь четверть институтов в результате преобразований переориентировались на взаимодействие с бизнесом и привлекли негосударственные источники финансирования.

Участники семинара обсудили различные аспекты государственно-частного партнерства на примере CNR и перспективы его развития. В части критики сложившейся системы было высказано предположе- 
ние, что реформа нанесла тройной удар по эффективности институтов. Все неэффективные исследователи сохранили свои места без каких-либо стимулов к повышению результативности; к тому же реорганизация разрушила сложившиеся исследовательские команды, а управление крупными структурами стало более бюрократизированным и менее гибким. Помимо этого, после внедрения дополнительного проектного администрирования институты потеряли самостоятельность в координировании собственных проектов трансфера технологий.

Тему продолжил доклад Станислава Заиченко «Оценка государственных научных организаций в России». В отечественной науке исторически сложилась практика выделения «лучших» («центров превосходства»), ориентированная на предоставление особого статуса, преференций и дополнительных финансовых средств небольшой группе организаций, прошедших отбор на основе экспертной оценки потенциала и результативности. В этом контексте была рассмотрена политика в отношении государственных научных центров (ГНЦ) и национальных исследовательских университетов (НИУ). В силу того что число бенефициаров невелико, а предоставляемые преференции не всегда значительны (как в случае с ГНЦ), оценивание ограничивалось простым экспертным отбором без особых требований как к составу экспертов, так и к процедурам оценки (с точки зрения открытости, прозрачности, публичного обсуждения, привлечения международных экспертов и пр.). К тому же в России еще не было прецедента подобного рода оценок, которые, по опыту многих зарубежных стран, требуют значительных ресурсов и времени (как, например, системы «Research Assessment Exercise» и «Research Excellence Framework» в Великобритании). Характерно, что наиболее масштабный проект центра превосходства в формате национального исследовательского центра пока реализован лишь в рамках одной организации (НИЦ «Курчатовский институт»).

Как показали исследования ИСИЭЗ НИУ ВШЭ, в 2007 г. более трети отечественных научных организаций (включая ряд ГНЦ, ранее прошедших отбор на получение данного статуса) демонстрировали крайне низкую результативность, либо вообще утратили научный профиль. «Таким образом, назрела необходимость в серьезном пересмотре существующих практик оценки и в формировании принципиально новых подходов к обеспечению качества оценивания», - отметил С. Заиченко. Особую проблему составляет отсутствие обратной связи между оцениванием и распределением финансирования по его итогам, как это принято в научно-технической политике многих стран.

В качестве ориентира для дальнейшего развития системы оценки научных организаций в России докладчик представил наработки ИСИЭЗ НИУ ВШЭ по концепции и методам оценивания потенциала и результативности ИиР. Общей идеей является переход к единой комплексной системе, подразумевающей несколько уровней оценки (от научных сетей до отдельных организаций, коллективов и исследователей) и диверсифицированный методический подход, охватывающий анализ статистических индикаторов и не- формализованную экспертизу каждой организации. В связи с этим была предложена процессная модель центра превосходства с интегрированными механизмами оценивания в цепях управления и финансирования. В любой формализованной системе оценивания неизбежно закладывается некоторая предопределенная модель успеха, в то время как на практике эффективность научной и инновационной деятельности может достигаться разными путями. В качестве иллюстрации были представлены результаты проведенного ИСИЭЗ НИУ ВШЭ анализа стратегий превосходства научных организаций и вузов. Подобная проблема может быть решена только на уровне индивидуализированной оценки, учитывающей уникальные особенности той или иной организации.

Второе выступление Говарда Раша посвящалось проблеме бенчмаркинга. Основываясь на трех бенчмаркинговых исследованиях по оценке государственных научных организаций, проведенных по заказам правительств Великобритании, Венесуэлы, а также Еврокомиссии, Г. Раш рассмотрел классификацию факторов успеха отобранных организаций. В случае Британии была выделена особая категория исследовательских организаций — «катапульты», привлекшая повышенное внимание правительства. Таким образом, были обозначены центры, способные оказывать услуги компаниям из различных секторов экономики, сотрудничающие с лучшими британскими и зарубежными университетами и научными институтами и являющиеся общепризнанными центрами превосходства по соответствующим направлениям. Перед ними стояла непростая задача снизить риски для компаний, доведя продукцию последних до коммерциализации.

В ходе итоговой дискуссии участники подняли ряд фундаментальных вопросов о необходимости четкого понимания политиками и администраторами объектов и процедур оценивания. Разнообразие научных должностей и дисциплинарных направлений чрезвычайно затрудняет подбор адекватной шкалы результативности (а особенно - качества) ИиР. Помимо этого, научные организации в составе национальной системы науки и технологий могут иметь разные институциональные функции, определяющие масштабы, состав и специфику результатов деятельности. Другая проблема касается методов оценки. Так, оценка по факту (ex-post) является точной и беспристрастной, но всегда обращена на достижения организаций и индивидуальных исследователей в прошлом, что затрудняет ее использование для действий в будущем. Оценивание «ex-ante» в форме экспертизы заявленных на будущее результатов, стратегий развития и соответствующих целевых ориентиров отвечает требованиям управления качеством, но не гарантирует верность оценок. Решение состоит в осознанном поиске баланса между этими полюсами, в то время как автоматическое применение лишь одного из инструментов может стать причиной изначальной негодности всей выстроенной системы оценивания. В продолжение темы эксперты вернулись и к вопросу о соотношении формализованных и неформализованных оценок. Дискуссанты пришли к выводу, что оценка может дать более позитивный эффект, когда является инструментом развития и поощрения, 
а не «наказания» (лишение статусов, реструктуризация и закрытие организаций и т. п.). В последнем случае скорее уместно говорить лишь о контроле соблюдения минимальных стандартов, регламентированных типовыми должностными требованиями для работников или уставными документами и стратегиями развития для организаций. Остается выяснить, имеют ли исследователи, научные коллективы и организации возможность в каждой конкретной ситуации повысить свою результативность и какие стимулы для них наиболее значимы. Углубленная неформализованная оценка позволила бы выявить узкие места, указать на точки приложения усилий по развитию, на внутренние и внешние барьеры и пути их преодоления. Подобная система уже не может реализоваться как разовое административное мероприятие: она должна превратиться в последовательную практику на уровне управления качеством в научной организации.

Участники признали, что обсуждаемые «идеальные» модели оценивания, несмотря на внешнюю привлекательность, могут вступить в конфликт с существующими нормами и традициями. В част- ности, в случае институтов Национального совета по исследованиям Италии большинство рациональных подходов к оценке будут отвергнуты профсоюзами, поскольку неизбежно внесут элементы дискриминации и неравенства возможностей. В российской практике препятствием могут стать отсутствие адекватной нормативно-правовой базы, противоречия действующим нормам трудового законодательства, система распределения бюджетных средств, ограничения организационно-правовых форм и пр.

Итогом семинара стало выявление наиболее перспективных областей для дальнейших исследований поведения научных организаций. В частности, речь идет о формировании типологии научных организаций, учитывающей институциональную специфику национальных инновационных систем, апробации типологии с использованием накопленных эмпирических данных и разработке механизмов интеграции подобной информации в доказательную базу научнотехнической и инновационной политики.

\title{
Public Research Organisations and Industry-Science Links
}

\author{
HSE Laboratory for Economics of Innovation \\ International Workshop
}

\begin{abstract}
$\mathrm{I}$ nternational experience shows that research organisations play a special role in the development of innovation systems. They are influenced by the changing socio-economic environment, priorities and tools of government regulation. Initially focused on networking with universities, enterprises and government, research organizations have diversified significantly in terms of their objectives, strategies and functional mechanisms.

The international workshop «Public Research Organisations and Industry-Science Links» held on 18-19 July 2013 at the Higher School of Economics by the HSE Laboratory for Economics of Innovation (LEI) was devoted to a discussion of the state-of-art of research on the relations between science and industry, with a special emphasis on the role of research organisations as actors in innovation systems.

The workshop agenda addressed such questions as:

- What lessons have been drawn from several decades of studying the relations between the public science base and industrial innovation (and innovation systems) more generally?

- How are the institutional and funding structures of public research evolving? What drives these changes, and how far can we assess the consequences?

- What is the need for, and consequences of, strategies and tools for performance evaluation at individual, institutional and system levels?

- What are the needs for further research in this area?

The workshop was attended by the specialists from LEI and HSE Institute for Statistical Studies and Economics of Knowledge as well as scholars from the University of Manchester (UK), the University of Brighton (UK), the University of Twente (Netherlands) and the National Research Council (Italy).
\end{abstract}




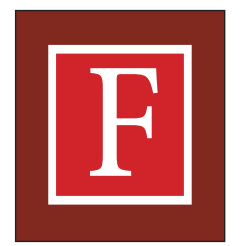

ISSN 1995-459X 